Prepared for the U.S. Department of Energy under Contract DE-AC05-76RL01830

\title{
Hydrogeologic Evaluation of a Ground-Source Cooling System at the BSF/CSF on the Battelle \\ Campus: Final Report
}

VL Freedman $^{(\mathrm{a})} \quad$ JA Horner $^{(\mathrm{a})}$

RD Mackley ${ }^{(a)} \quad$ TW Moon $^{(a)}$

SR Waichler ${ }^{(a)} \quad$ DR Newcomer ${ }^{(a)}$

(a) Pacific Northwest National Laboratory

(b) GSI Water Solutions, Inc.
DJ DeSmet ${ }^{(a)}$

KA Lindsey ${ }^{(b)}$

JJ Porcello ${ }^{(b)}$

March 2010

Pacific Northwest

NATIONAL LABORATORY

Proudly Operated by Battelle Since 1965 


\title{
DISCLAIMER
}

This report was prepared as an account of work sponsored by an agency of the United States Government. Neither the United States Government nor any agency thereof, nor Battelle Memorial Institute, nor any of their employees, makes any warranty, express or implied, or assumes any legal liability or responsibility for the accuracy, completeness, or usefulness of any information, apparatus, product, or process disclosed, or represents that its use would not infringe privately owned rights. Reference herein to any specific commercial product, process, or service by trade name, trademark, manufacturer, or otherwise does not necessarily constitute or imply its endorsement, recommendation, or favoring by the United States Government or any agency thereof, or Battelle Memorial Institute. The views and opinions of authors expressed herein do not necessarily state or reflect those of the United States Government or any agency thereof.

\author{
PACIFIC NORTHWEST NATIONAL LABORATORY \\ operated by \\ BATTELLE \\ for the \\ UNITED STATES DEPARTMENT OF ENERGY \\ under Contract DE-ACO5-76RL01830
}

Printed in the United States of America
Available to DOE and DOE contractors from the Office of Scientific and Technical Information,
P.O. Box 62, Oak Ridge, TN 37831-0062;
ph: (865) 576-8401
fax: (865) 5765728
email: reports@adonis.osti.gov

\author{
Available to the public from the National Technical Information Service, \\ U.S. Department of Commerce, 5285 Port Royal Rd., Springfield, VA 22161 \\ ph: (800) 553-6847 \\ fax: (703) 605-6900 \\ email: orders@nits.fedworld.gov \\ online ordering: http://www.ntis.gov/ordering.htm
}




\title{
Hydrogeologic Evaluation of a Ground-Source Cooling System at the BSF/CSF on the Battelle Campus: Final Report
}

\author{
VL Freedman $^{(a)} \quad$ JA Horner $^{(\mathrm{a})} \quad$ DJ DeSmet $^{(\mathrm{a})}$ \\ RD Mackley $^{(\mathrm{a})} \quad$ TW Moon $^{(\mathrm{a})} \quad$ KA Lindsey $^{(\mathrm{b})}$ \\ SR Waichler $^{(\mathrm{a})} \quad$ DR Newcomer $^{(\mathrm{a})} \quad$ JJ Porcello $^{(\mathrm{b})}$
}

(a) Pacific Northwest National Laboratory

(b) GSI Water Solutions, Inc.

March 2010

Prepared for

the U.S. Department of Energy

under Contract DE-AC05-76RL01830

Pacific Northwest National Laboratory

Richland, Washington 99352 


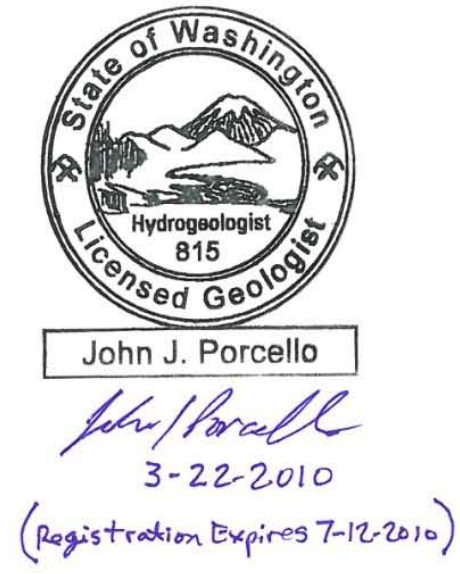




\section{Summary}

This report documents both the field characterization activities and the numerical modeling effort at the Biological Sciences Facility (BSF) and the Computational Sciences Facility (BSF/CSF) site to determine the viability of an open-loop ground source heat pump (GSHP). The primary purpose of the integrated field and modeling study was to determine far-field impacts related to a non-consumptive use water right for the well field containing four extraction and four injection wells.

In the field, boreholes were logged and used to develop the geologic conceptual model. Hydraulic testing was performed to identify hydraulic properties and determine sustainable pumping rates.

Estimates of the Ringold hydraulic conductivity (60 to $150 \mathrm{~m} / \mathrm{d}$ ) at the BSF/CSF site were consistent with the local and regional hydrogeology as well as estimates previously published by other investigators. Sustainable pumping rates at the extraction wells were variable (100 to $700 \mathrm{gpm}$ ) and confirmed field observations of aquifer heterogeneity.

Field data were used to develop a numerical model of the site. Simulations assessed the potential of the well field to impact nearby contaminant plumes, neighboring water rights, and the thermal regime of nearby surface water bodies. Using steady-state flow scenarios in conjunction with particle tracking, a radius of influence of 400 to $600 \mathrm{~m}$ was identified around the well field. This distance was considerably shorter than the distance to the closest contaminant plume ( 0.8 km northwest to the Department of Energy Horn Rapids Landfill) and the nearest water right holder ( 1.2 km southeast to the City of Richland Well Field). Results demonstrated that current trajectories for nearby contaminant plumes will not be impacted by the operation of the GSHP well field.

The objective of the energy transport analysis was to identify potential thermal impacts to the Columbia River under likely operational scenarios for the BSF/CSF well field. Estimated pumping rates and injection temperatures were used to simulate heat transport for a range of hydraulic conductivity estimates for the Ringold Formation. The long-term operational scenario was simulated using conservative assumptions that assumed that river water did not intrude in the near shore groundwater. This operational scenario simulated continuous heat rejection, a condition anticipated once the BSF/CSF is fully loaded with laboratory and computer equipment. When hourly peak conditions were simulated as one month long peak to account for two 12-hour peak periods, the maximum change in groundwater temperature at a point along the shoreline was $+0.9^{\circ} \mathrm{C}$ from ambient. This change is less than $20 \%$ of the natural diurnal variability in groundwater temperatures at the shoreline. These findings are based on highly conservative assumptions for the GSHP system's operations, assumptions to which the model simulation results are highly sensitive. Other attributes of the model (such as aquifer hydraulic parameters and boundary conditions) were selected in a careful and conservative manner and have some influence on the model results, though much less than the assumed operational scenario. 



\section{Acronyms and Abbreviations}

$\begin{array}{ll}\text { BSF } & \text { Biological Sciences Facility } \\ \text { CSF } & \text { Computational Sciences Facility } \\ \text { DOE } & \text { U.S. Department of Energy } \\ \text { EBF } & \text { electromagnetic borehole flowmeter } \\ \text { GSHP } & \text { ground source heat pump } \\ \text { GSI } & \text { GSI Water Solutions, Inc. } \\ \text { MODFLOW } & \text { Modular Three-Dimensional Finite-Difference Groundwater Flow Model } \\ \text { PAQW } & \text { Pasco Monitoring Station } \\ \text { PNNL } & \text { Pacific Northwest National Laboratory } \\ \text { PVC } & \text { polyvinyl chloride } \\ \text { RPL } & \text { Radiochemical Processing Laboratory } \\ \text { STOMP } & \text { Subsurface Transport Over Multiple Phases } \\ \text { STOMP-W } & \text { water mode of STOMP } \\ \text { STOMP-WAE } & \text { water-air-energy mode of STOMP } \\ \text { TCE } & \text { trichloroethylene } \\ \text { TDS } & \text { total dissolved solids } \\ \text { VOA } & \text { volatile organic analysis } \\ \text { WAC } & \text { Washington Administrative Code } \\ \text { WS DOE } & \text { Washington State Department of Ecology } \\ & \end{array}$





\section{Acknowledgments}

The authors would like to express their gratitude for the careful reviews provided by Pacific Northwest National Laboratory’s (PNNL’s) Vince Vermeul, Mark Freshley, Signe Wurstner, and Bruce Bjornstad. We are grateful for the field support of PNNL staff members Kyle Parker and Mark Sweeney during drilling and hydraulic testing as well as Dr. Frank Spane for insight on the hydraulic testing activities. Thanks also go to Paul Thorne for immediately responding to requests to integrate geological field data into the EarthVision database and provide it in a useable format for the modeling effort.

Thanks also go to Cindy Rakowski for generating several different versions of the model grid as well as to Duane Ward for providing Geographic Information System support. 



\section{Contents}

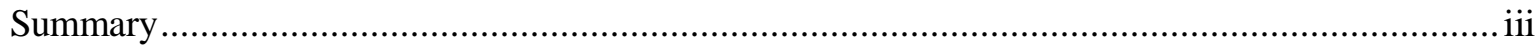

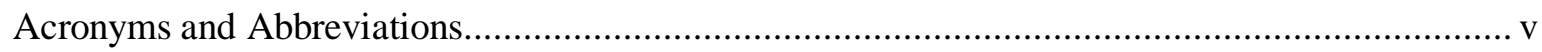

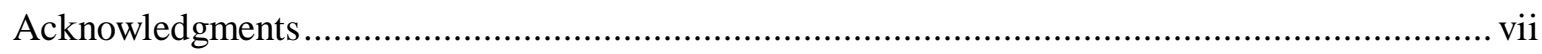

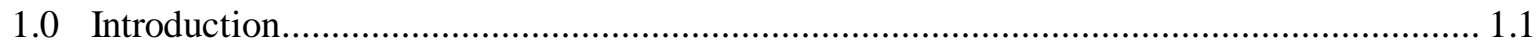

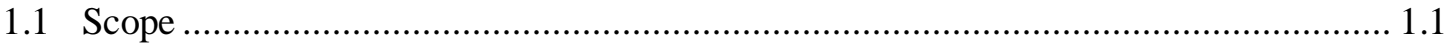

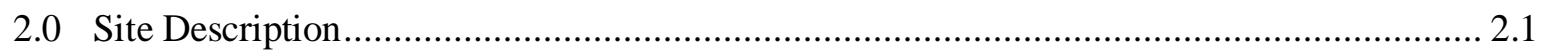

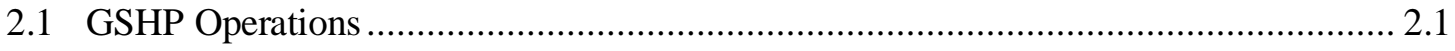

2.1.1 Winter Operations................................................................................. 2.4

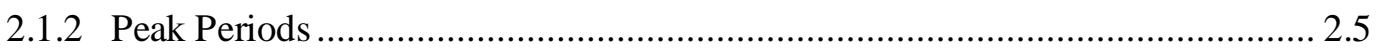

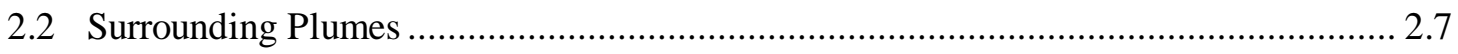

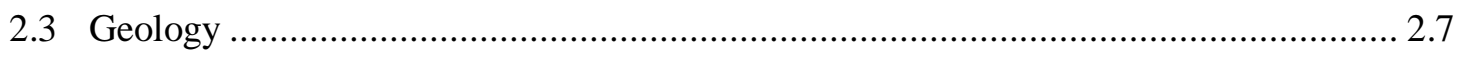

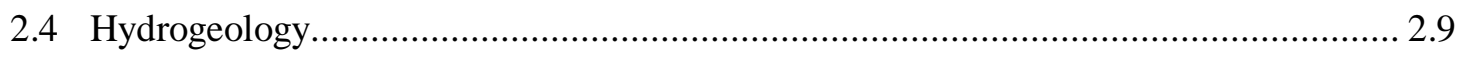

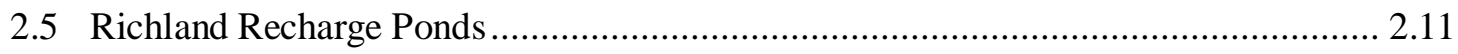

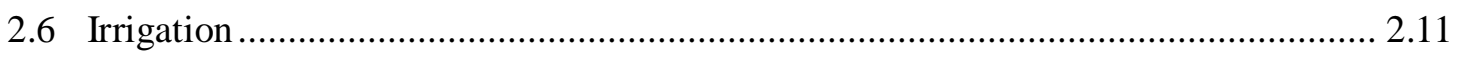

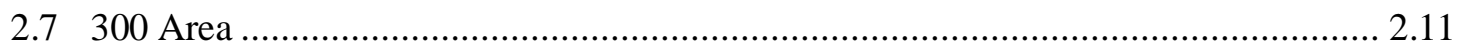

2.8 Surface Water Features..................................................................................... 2.11

2.9 Thermal Regime of the Columbia River and Hyporheic Zone ................................ 2.14

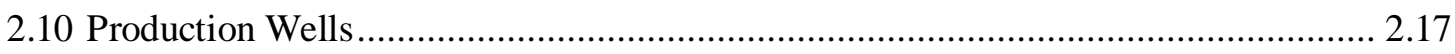

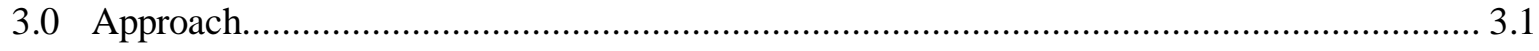

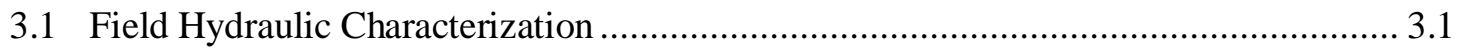

3.2 Sustainability of Pumping Operations .................................................................. 3.2

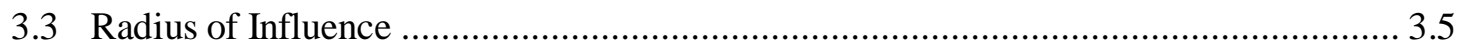

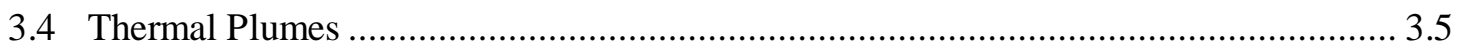

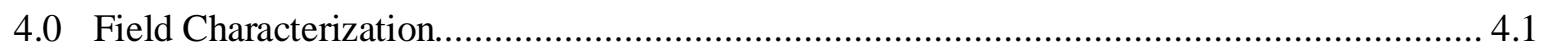

4.1 Hydraulic Conductivity Estimates.......................................................................... 4.1

4.1.1 Results from Constant-Rate Pumping Test in Well 2 .................................... 4.1

4.2 Sustainable Pumping Rates............................................................................... 4.4

4.3 Groundwater Samples................................................................................ 4.4

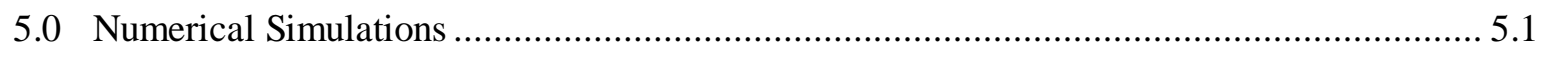

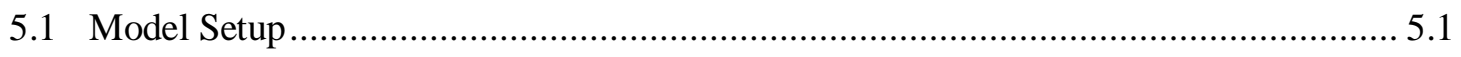

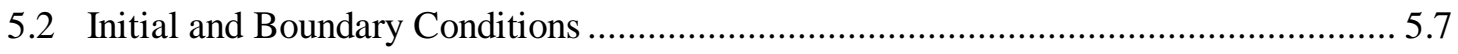

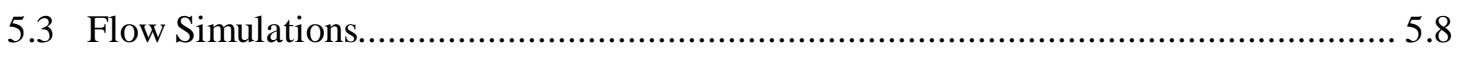

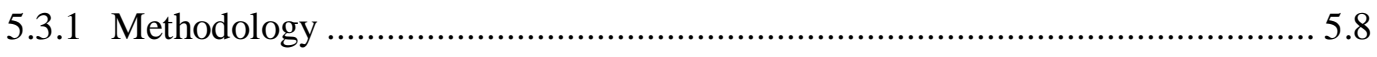

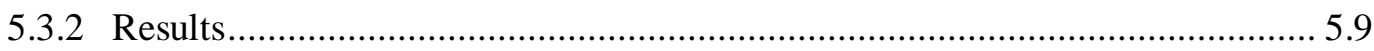

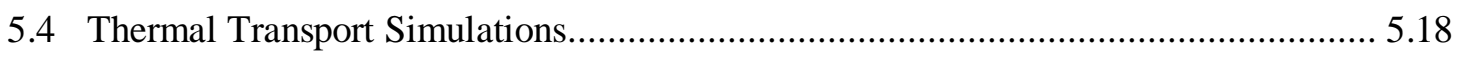

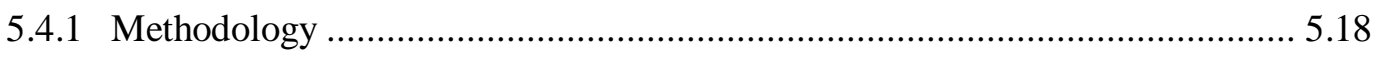




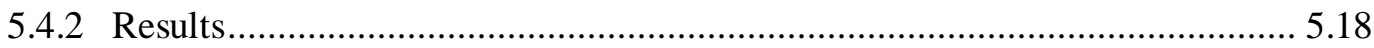

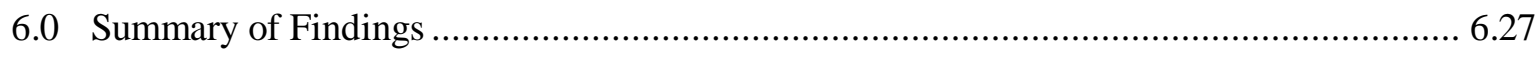

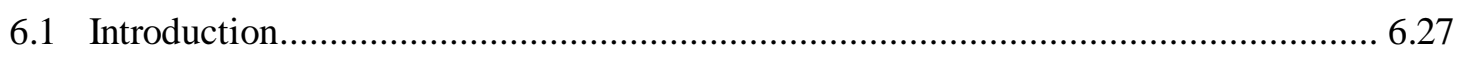

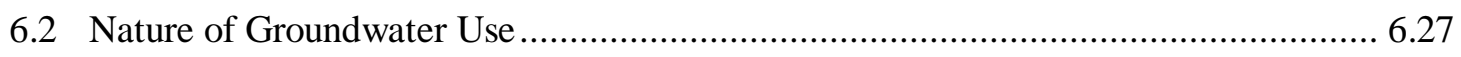

6.3 Potential to Affect Offsite Groundwater Contamination........................................... 6.28

6.4 Potential for Thermal Plumes to Impact the Columbia River.................................... 6.28

6.4.1 GSHP Injection Rates and Temperatures................................................ 6.29

6.4.2 Subsurface Thermal Plume (Heat Transport) Modeling ................................ 6.29

6.4.3 Modeling Implications for Potential Thermal Impacts on the Columbia River 6.30

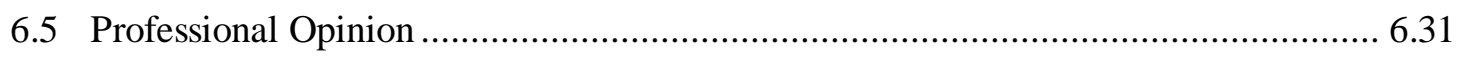

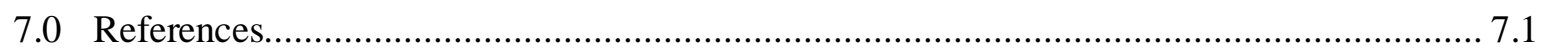

Appendix A: Regional Contaminant Plumes ......................................................................... 1

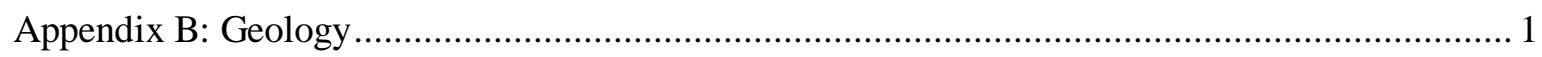

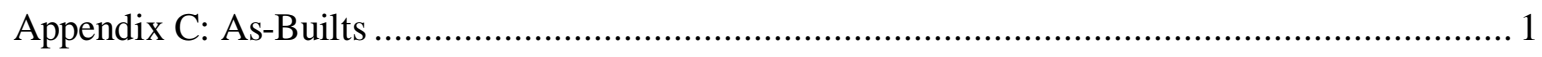

Appendix D: Hydraulic Characterization .......................................................................... 1

Appendix E: Heat Transport Results: Case 1a (60 m/d Ringold Hydraulic Conductivity, Average

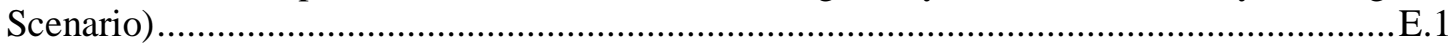

Appendix F: Heat Transport Results: Case 1b (60 m/d Ringold Hydraulic Conductivity, Peak

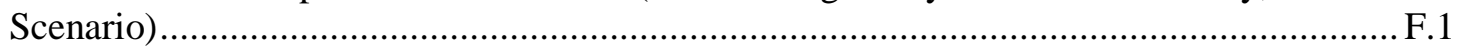

Appendix G: Heat Transport Results Case 2a (150 m/d Ringold Hydraulic Conductivity, Average

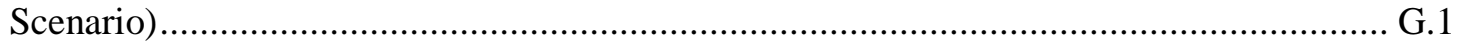

Appendix H: Heat Transport Results Case 2b (150 m/d Ringold Hydraulic Conductivity, Peak

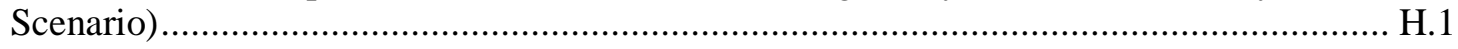




\section{Figures}

2.1. Site Map Showing the Location of the BSF/CSF Facility and the Well Locations. The southern border of the Hanford 300 Area is located $\sim 1.5 \mathrm{~km}$ north of the site, the AREVA facilities are $\sim 1.2$ $\mathrm{km}$ to the west, and the DOE Horn Rapids Landfill is $~ 1.2 \mathrm{~km}$ northwest of the site............ 2.1

2.2. Schematic Diagram of Central Heating System for the BSF/CSF 2.3

2.3. Total Number of Days in Which Temperatures Did Not Exceed $7.2^{\circ} \mathrm{C}\left(45^{\circ} \mathrm{F}\right)$ 2.5

2.4 a) Average, Minimum and Maximum Flow Rates Through the GSHP with Error Bars Denoting 1 Standard Deviation Above the Mean; b) Fraction of Time Spent in Peak Period. 2.6

2.5. Generalized Stratigraphic Column Depicting for the BSF/CSF Construction Site ........... 2.108

2.6. Geologic Cross Section Across the East Side of the BSF/CSF Site 2.129

2.7. Water Table Map, Spring, 2006

2.8. Surface Water Features Near the BSF/CSF Site. 2.1212

2.9. Columbia River Outflow 10-Year Average (1999-2008) at Pasco Monitoring Station (PAQW). 2.133

2.10. Locations of Springs Along the Columbia River.

2.144

2.11. 10-Year Average (1999-2008) of Water Temperatures in the Columbia River at the PAQW (Pasco, WA) Station (http://www.cbr.washington.edu/dart/river.html). The average groundwater temperature at the BSF/CSF site has been measured in 2009 at $16.4^{\circ} \mathrm{C}$. At the 300 Area, groundwater temperatures average $17^{\circ} \mathrm{C}$ (R. Peterson, personal communication)..........2.1515

2.12. (a) Temperatures in the Hyporheic Zone as Measured in 300 Area Wells and (b) 300 Area Well Locations (from Williams et al. 2007). 2.166

2.13. Well Locations at the BSF/CSF Site. Extraction Wells Are Located on the West and Injection Wells on the East. 2.177

2.14. Summary of Borehole Log and As-Built Diagram for Production Well \#2 2.188

3.1. (a) Observed Groundwater and River Levels and (b) Well Locations. Well locations marked in red are plotted in (a). Well locations marked in yellow were used in the triangulation presented in Figure 3.2. 3.3

3.2. Groundwater Gradient and Flow Direction Based on Triangulation of Manual Water Level Measurements from Wells 699-32-Ell, 699-S29-E10, and 699-S32-E13A 3.4

4.1. Neuman $(1972,1974,1975)$ Type-Curve Fits to the Drawdown (boxes) and Derivative (triangles) for Wells 2a (i), 2c (ii), and 1 (iii) for the Constant-Rate Withdrawal Test In Well 2 ......... 4.3

5.1. Features Included in the Model Domain. 5.1

5.2. Contact Between the Hanford and Ringold Formations. The Horn Rapids DOE landfill is outlined in light blue, the 300-Area outline is yellow, the Richland well locations are marked in dark blue, and the BSF/CSF facility and property are shown in green. Transect lines correspond to crosssections shown in Figure 5.4. 5.3

5.3. Saturated Thickness of the Ringold and Hanford Formations. The Horn Rapids DOE landfill is outlined in light blue, the 300-Area outline is yellow, the Richland well locations are marked in 
dark blue, and the BSF/CSF facility and property are shown in green. Transect lines correspond to cross-sections shown in Figure 5.4.

5.4. Geologic Cross-Sections Corresponding to the Numbered Transects

5.5. STOMP Model Grid $(49 \times 58 \times 44)$. The Horn Rapids DOE landfill is outlined in light blue, the 300-Area outline is yellow, the Richland well locations are marked in dark blue, and the BSF/CSF facility and property are shown in green. 5.6

5.6. Steady-State Water-Table Configuration With Particle Tracks for Particles Released at the Upgradient Western Boundary. Plots shown are for the Ringold hydraulic conductivity estimated at a) $60 \mathrm{~m} / \mathrm{d}$ and b) $150 \mathrm{~m} / \mathrm{d}$. 5.10

5.7. Difference Plots and Particle Tracks for Steady-State Pumping Rates of 1400 gpm (Cases 1 and 2) and 1900 gpm (Cases 3 and 4). Cases 1 and 3 assumed the saturated hydraulic conductivity of the Ringold Formation was $60 \mathrm{~m} / \mathrm{d}$; whereas Cases 2 and 4 assumed $150 \mathrm{~m} / \mathrm{d}$.... 5.13

5.8. Flow Paths for the Groundwater Flow System without Pumping (Black) and with Steady-State Pumping Rates (Red) of 1400 gpm (Cases 1 and 2) and 1900 gpm (Cases 3 and 4). Cases 1 and 3 assumed the saturated hydraulic conductivity of the Ringold Formation was $60 \mathrm{~m} / \mathrm{d}$; whereas Cases 2 and 4 assumed $150 \mathrm{~m} / \mathrm{d}$. 5.15

5.9. Capture Zones for Steady-State Pumping Rates of 1400 gpm (Cases 1 and 2) and 1900 gpm (Cases 3 and 4). Cases 1 and 2 assumed the saturated hydraulic conductivity of the Ringold Formation was $60 \mathrm{~m} / \mathrm{d}$; whereas Cases 2 and 4 assumed $150 \mathrm{~m} / \mathrm{d}$. 5.17

5.10. Mean Temperature Distribution for Case 2b (Peak Scenario, Ringold Hydraulic Conductivity of $150 \mathrm{~m} / \mathrm{d})$ 5.20

5.11. Maximum Temperature Distribution for Case 2b (Peak Scenario, Ringold Hydraulic Conductivity of $150 \mathrm{~m} / \mathrm{d})$.

5.12. Maximum Groundwater Temperatures Near the Columbia River Shoreline for Ringold Hydraulic Conductivities of $60 \mathrm{~m} / \mathrm{d}$ (Cases 1a,1b) and $150 \mathrm{~m} / \mathrm{d}$ (Cases 2a,2b). Ambient groundwater temperature at the BSF/CSF Site is plotted for reference. 5.22

5.13. Temperature Variability in the Hyporheic Zone Along the 300 Area Shoreline. The average ground water temperature at the $\mathrm{BSF} / \mathrm{CSF}$ site is $16.4^{\circ} \mathrm{C}$ 5.23

5.14. Groundwater Fluxes at the Eastern Boundary of the Domain for All Scenarios. 5.24 


\section{Tables}

2.1. Monthly Average Pumping Rates and Injection Temperatures....................................... 2.4

2.2. Monthly Peak Pumping Rates and Injection Temperatures ............................................ 2.4

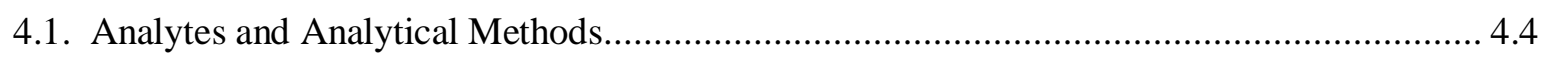

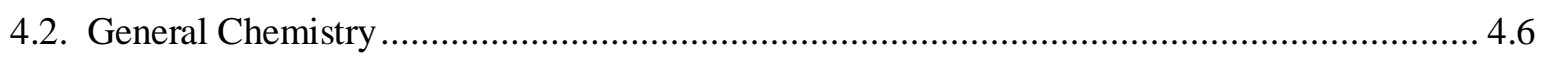

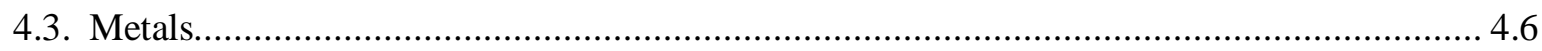

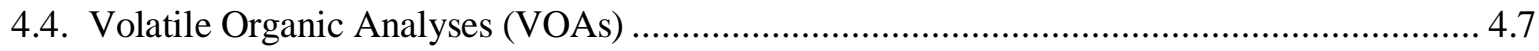

4.5. Total Alpha/Beta and Isotopic Analyses..................................................................... 4.7

5.1. Hydraulic and Thermal Input Parameters ................................................................... 5.7

5.2. Water-Level Comparison of Simulated and Observed Heads......................................... 5.11 


\subsection{Introduction}

Ground source heat pumps (GSHPs) have been incorporated in two laboratory facilities recently constructed at the Pacific Northwest National Laboratory (PNNL) campus located in Richland, Washington. The Biological Sciences Facility (BSF) and the Computational Sciences Facility (CSF) use an open-loop GSHP, an efficient, renewable energy technology for space heating and cooling. In an open-loop system, the technology relies directly on groundwater's constant temperature with depth, by using it as a heat source to heat the buildings in the winter, and as a heat sink in the summer. Open-loop systems are pollution free. The heat pump merely removes or adds heat to the water without adding any pollutants. The only change in the water returned to the environment is an increase or decrease in temperature. Because the system will be injecting the same volume of water that is extracted from the subsurface, the net water use is non-consumptive.

Open-loop GSHPs are a viable alternative to conventional space heating and cooling systems because of their higher operating efficiency, especially during the heating season (Florides and Kalogirao 2007). Only a small amount of electricity input is required to run the groundwater pumps and a compressor. The energy output is approximately four times greater than the input and operates emissions-free. Despite the fact that the technology and energy savings are well established, the extensive use of the technology is limited in the United States. This is due in part to capital costs associated with drilling and installing a GSHP and uncertainty in potential long-term environmental impacts and sustainability. Lack of local agency guidance on evaluating potential impacts can cause excessive administrative restrictions that discourage investments in the technology.

\subsection{Scope}

This report presents the characterization of the geology, hydrogeology, and nearby surface water bodies at the BSF/CSF site. It also investigates the potential impacts that the proposed GSHP may have on the local groundwater system. To this end, three tasks have been carried out: field characterization activities, a numerical modeling analysis, and a survey of existing data in the literature. This information is used in conjunction with professional judgment to predict the potential impacts of the well field.

The results of all of the activities are presented in this report at two levels. In the main document, a summary-level understanding of the geology, hydrogeology, and well system operations is presented. Also included is a description of the approach that is used to assess system impacts. Results of the numerical modeling analysis are also presented in the main document, as well as a professional opinion that integrates the knowledge gained from all activities into an assessment of potential impacts.

More detailed site descriptions are provided in the report appendices. This includes a description of nearby existing contaminant plumes summarized from the literature, a detailed description of the geologic conceptual model, and results of the step- and constant-rate well pump tests. A description of the well asbuilts is also provided in the appendices because the main document focuses on identifying the potential environmental impacts of the well field.

The primary purpose of this hydrogeologic report is to provide the Washington State Department of Ecology (WS DOE) with the information needed to grant a non-consumptive groundwater right to operate 
the open-loop GSHP. This includes providing information on the well locations, well construction, proposed pumping rates, and the potential impacts that the well field may have on the environment. Specifically, this report provides information to determine 1) the sustainability of the well system, 2) the potential to impact nearby contaminant plumes, 3) the potential to impact neighboring water rights, and 4) the potential to impact the thermal regime of nearby surface water bodies. 


\subsection{Site Description}

The open-loop GSHP is connected to two laboratory facilities that have been recently constructed at the PNNL campus located in Richland, Washington: the BSF and the CSF. The BSF/CSF property occupies $\sim 50,000 \mathrm{~m}^{2}$ and is located on the west side of the PNNL campus (Figure 2.1). It is bounded by the Hanford Site to the north, a former U.S. Department of Energy (DOE) Horn Rapids Landfill to the northwest, and the Columbia River to the east. The Yakima River is located $\sim 2 \mathrm{~km}$ to the south of the BSF/CSF site.

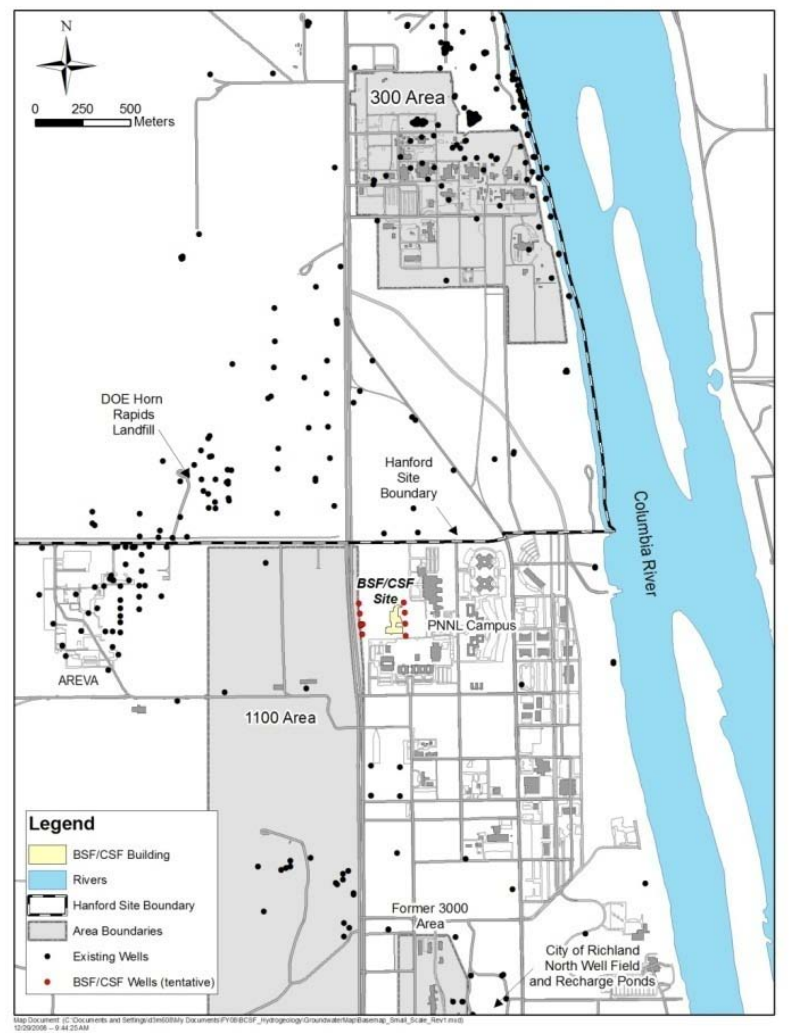

Figure 2.1. Site Map Showing the Location of the BSF/CSF Facility and the Well Locations. The southern border of the Hanford 300 Area is located $\sim 1.5 \mathrm{~km}$ north of the site, the AREVA facilities are $\sim 1.2 \mathrm{~km}$ to the west, and the DOE Horn Rapids Landfill is $\sim 1.2 \mathrm{~km}$ northwest of the site.

A complete understanding of the geology and hydrogeology of the site is necessary to determine the system feasibility and assess impacts. In this section, the geography is described with respect to nearby sources of contamination, followed by a description of the site geology and hydrogeology.

\subsection{GSHP Operations}

The BSF/CSF facility is located in Richland, WA, a semi-arid climate, that receives an average annual precipitation of 180 to $200 \mathrm{~mm}$. Temperatures range from as low as $10^{\circ} \mathrm{F}\left(-12^{\circ} \mathrm{C}\right)$ in the winter to 
as high as $110^{\circ} \mathrm{F}\left(43^{\circ} \mathrm{C}\right)$ in the summer. Seasonal variations in space conditioning exist, with summer cooling loads exceeding those of the winter heating loads.

A common central heating and cooling system serves the BSF/CSF facilities. The systems were combined because the biological building (BSF) is a research laboratory that requires $100 \%$ outside air, whereas the computational building (CSF) houses computer equipment that requires cooling year round. The system operates such that waste heat is removed from the CSF building and used to heat the BSF during the heating season. In addition to the redistribution of heat within the facility, the central system is coupled to the open-loop groundwater system that extracts heat from the groundwater during the heating season. During the cooling season, the groundwater receives heat (i.e., heat is rejected to the groundwater).

During the heating season, the system is coupled to both the chiller and the heat pump. Water first flows through the chiller to heat the condenser water and then flows to the heat pump. Water leaving the heat pump and rejected to groundwater has an expected temperature range of 13.0 to $14.7^{\circ} \mathrm{C}\left(56\right.$ to $59^{\circ} \mathrm{F}$ ). During the cooling season, the system is coupled to a chiller that rejects heat to the groundwater. In the summer, the temperature of the water rejected to groundwater is expected to range from 17.7 to $19.9^{\circ} \mathrm{C}$ (64 to $\left.68^{\circ} \mathrm{F}\right)$.

An automatic control system modulates the amount of water extracted from the well field and pumped through the heat exchanger to keep the condenser water warm enough to maximize the heat pump coefficient of performance and cool enough for the chillers to operate efficiently. Hence, groundwater will not be pumped when the outdoor air temperature falls below $45^{\circ} \mathrm{C}\left(7.2^{\circ} \mathrm{F}\right)$, since it will be more energy efficient to only operate the chiller. A diagram of the system is shown in Figure 2.2. 


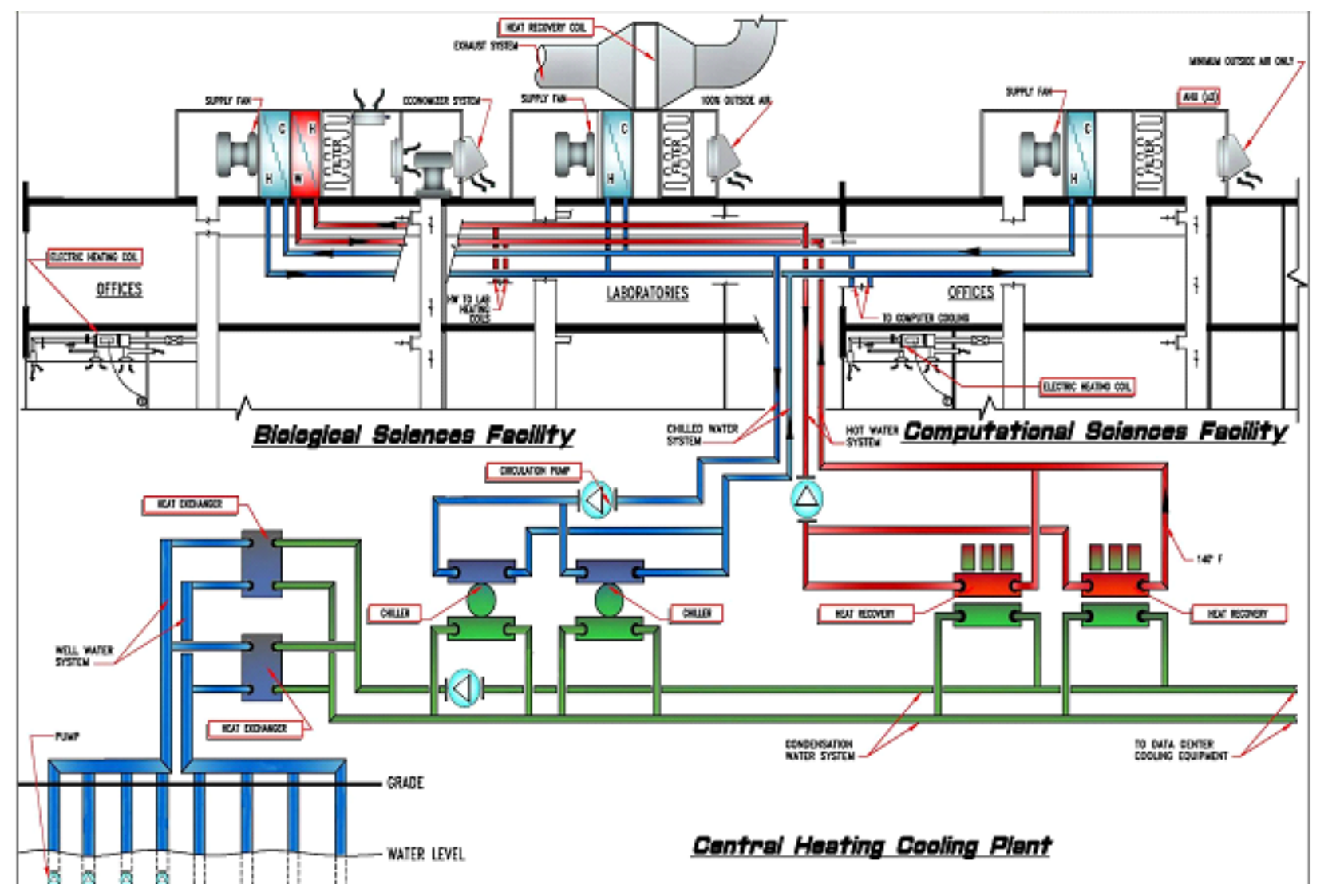

Figure 2.2. Schematic Diagram of Central Heating System for the BSF/CSF

The DOE-2 simulation program was used to design the heating and cooling system at the BSF/CSF facility. Given 30 years of climate data and a description of the heating and cooling equipment, the program was used to optimize energy efficiency while maintaining thermal comfort and costeffectiveness. Output from this program, as well as data from a 30-day test, were used to formulate likely operational scenarios that describe pumping rates and water injection temperatures (see Section 3.4). At the time of this writing, the 30-day test is still on-going, but data obtained from the first two weeks of the test show that the average temperature drop across the exchanger is $2.5^{\circ} \mathrm{C}\left(4.5^{\circ} \mathrm{F}\right)(\mathrm{C}$. Cataldo, personal communication). .

Monthly averages and peaks for both pumping rates and injection temperatures are shown in Table 2.1 and Table 2.2, and for design purposes, assumed that the GSHP would be operational yearround. Monthly pumping rates are calculated based on the injection temperature of $18.9^{\circ} \mathrm{C}\left(66^{\circ} \mathrm{F}\right), 2.5$ ${ }^{\circ} \mathrm{C}$ above the ambient groundwater temperature of $16.4^{\circ} \mathrm{C}$. Although peak rates and injection temperatures are shown on a monthly basis, they will only be reached for a few hours of the day when cooling needs are at a maximum.

Table 2.1 and Table 2.2 show that the injection temperatures are consistently higher than the ambient groundwater temperature of $16.4^{\circ} \mathrm{C}\left(61.5^{\circ} \mathrm{F}\right)$. Once the BSF/CSF is fully equipped with laboratory and computer equipment, heat rejection to groundwater will be required year round. However, the facility is 
not expected to be fully operational for another 5 years. Until that time, cool water injection to the subsurface will occur during the heating season.

Table 2.1. Monthly Average Pumping Rates and Injection Temperatures

\begin{tabular}{lcccccc}
\hline & Jan & Feb & Mar & Apr & May & Jun \\
\cline { 2 - 6 } Pumping Rate $(\mathrm{gpm})$ & 440 & 418 & 470 & 471 & 533 & 595 \\
Injection Temperature $\left({ }^{\circ} \mathrm{C}\right)$ & 18.9 & 18.9 & 18.9 & 18.9 & 18.9 & 18.9 \\
\hline & Jul & Aug & Sep & Oct & Nov & Dec \\
\cline { 2 - 6 } Pumping Rate $(\mathrm{gpm})$ & 727 & 650 & 554 & 496 & 445 & 458 \\
Injection Temperature $\left({ }^{\circ} \mathrm{C}\right)$ & 18.9 & 18.9 & 18.9 & 18.9 & 18.9 & 18.9 \\
\hline
\end{tabular}

Table 2.2. Monthly Peak Pumping Rates and Injection Temperatures

\begin{tabular}{lcccccc}
\hline & Jan & Feb & Mar & Apr & May & Jun \\
\cline { 2 - 6 } Pumping Rate $(\mathrm{gpm})$ & 639 & 649 & 706 & 989 & 1173 & 1541 \\
Injection Temperature $\left({ }^{\circ} \mathrm{C}\right)$ & 19.7 & 19.7 & 19.7 & 19.7 & 19.7 & 19.7 \\
\hline & Jul & Aug & Sep & Oct & Nov & Dec \\
\cline { 2 - 7 } Pumping Rate (gpm) & 1900 & 1900 & 1899 & 1036 & 736 & 648 \\
Injection Temperature $\left({ }^{\circ} \mathrm{C}\right)$ & 19.9 & 19.7 & 19.7 & 19.7 & 19.7 & 19.7 \\
\hline
\end{tabular}

\subsubsection{Winter Operations}

As previously stated, energy efficiency dictates that only the chiller will be operated when the outdoor air temperature falls below $7.2^{\circ} \mathrm{C}\left(45^{\circ} \mathrm{F}\right)$. Hence, extraction and injection wells will not be operated for extended periods of time during the winter months. To estimate the amount of time that the GSHP will not be operational, Hanford meteorological data were obtained for the time period 1955-2009. Temperature data were analyzed by tabulating the total number of hours per day in which the temperature was less than or equal to $7.2^{\circ} \mathrm{C}$. These data are shown in Figure 2.3, and are plotted as the number of days per year with temperatures $\leq 7.2^{\circ} \mathrm{C}$. These data demonstrate that on average, the annual number of days that are $\leq 7.2^{\circ} \mathrm{C}$ is 133 , with a minimum and maximum for the 54 year record as 111 and 151 days, respectively. Hence, based on these data, on average, the system would not be operational for 4.4 months per year, with a range of 3.7 to 5.0 months with the GSHP offline. 


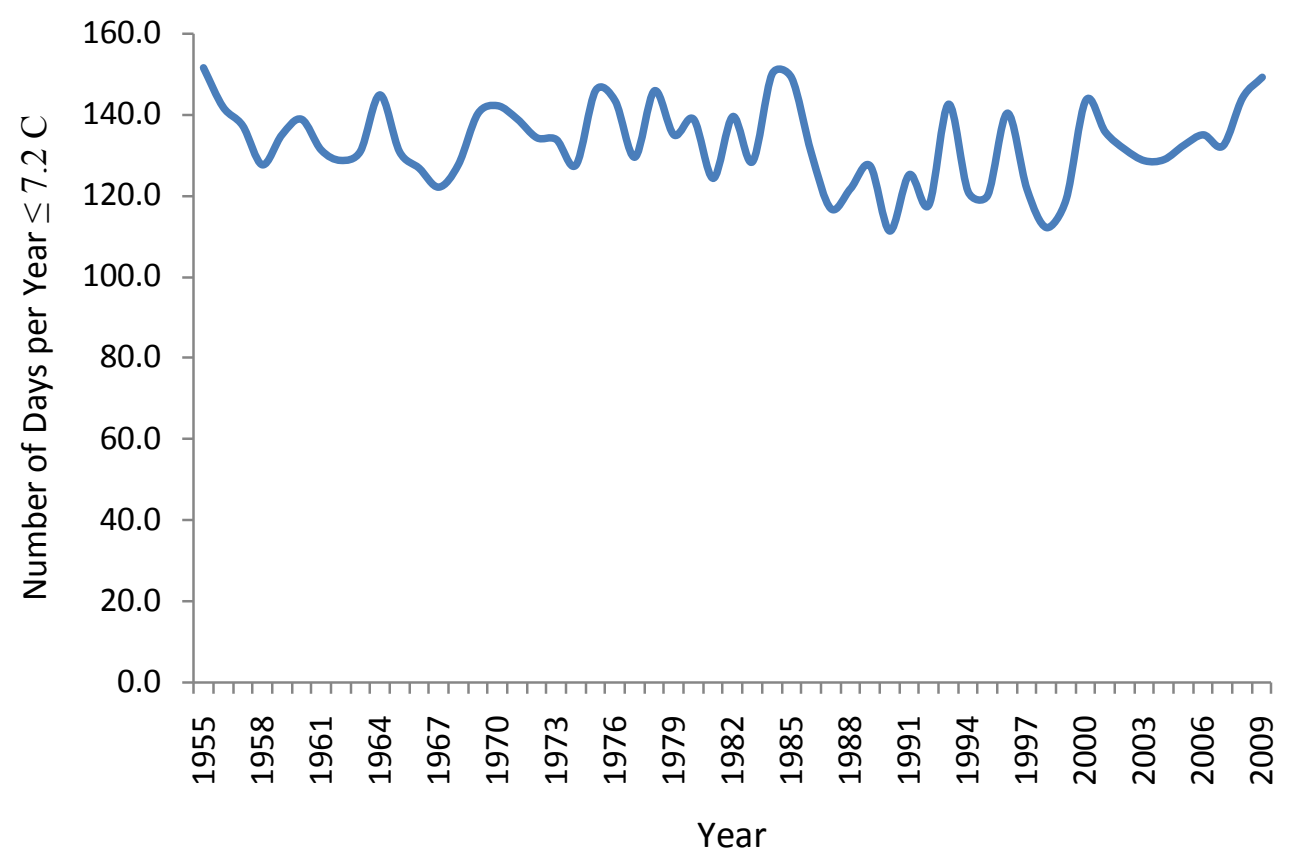

Figure 2.3. Total Number of Days in Which Temperatures Did Not Exceed $7.2^{\circ} \mathrm{C}\left(45^{\circ} \mathrm{F}\right)$

\subsubsection{Peak Periods}

Hourly simulation data output from the building simulation program were used to determine the length of time at which peak pumping rates would occur. Although Table 2.2 identifies the peak rates on a monthly basis, peak pumping rates occur daily on an hourly basis, typically in the afternoon hours, when cooling needs are at a maximum. To determine the peak period, average flow rates and their standard deviations were first determined on a monthly basis (see Figure 2.4a). These data differ slightly from the average rates presented in Table 2.1 because only one year of data were used. Figure 2.4a) also shows that peak rates were much higher than the average, and not significantly greater than the minimum. A flow rate was classified as a peak rate if it was greater than the mean rate plus $25 \%$ of the standard deviation. For example, in April, the standard deviation was only 10 gpm, with a monthly average of 394.5 gpm. In July, the average flow rate was 469 gpm, and the standard deviation was $147 \mathrm{gpm}$. Hence, in April, a peak flow rate occurred if the rate was $\geq 471.5 \mathrm{gpm}$, whereas in July, a peak period was identified if the rate was $\geq 505.8 \mathrm{gpm}$. 
a)

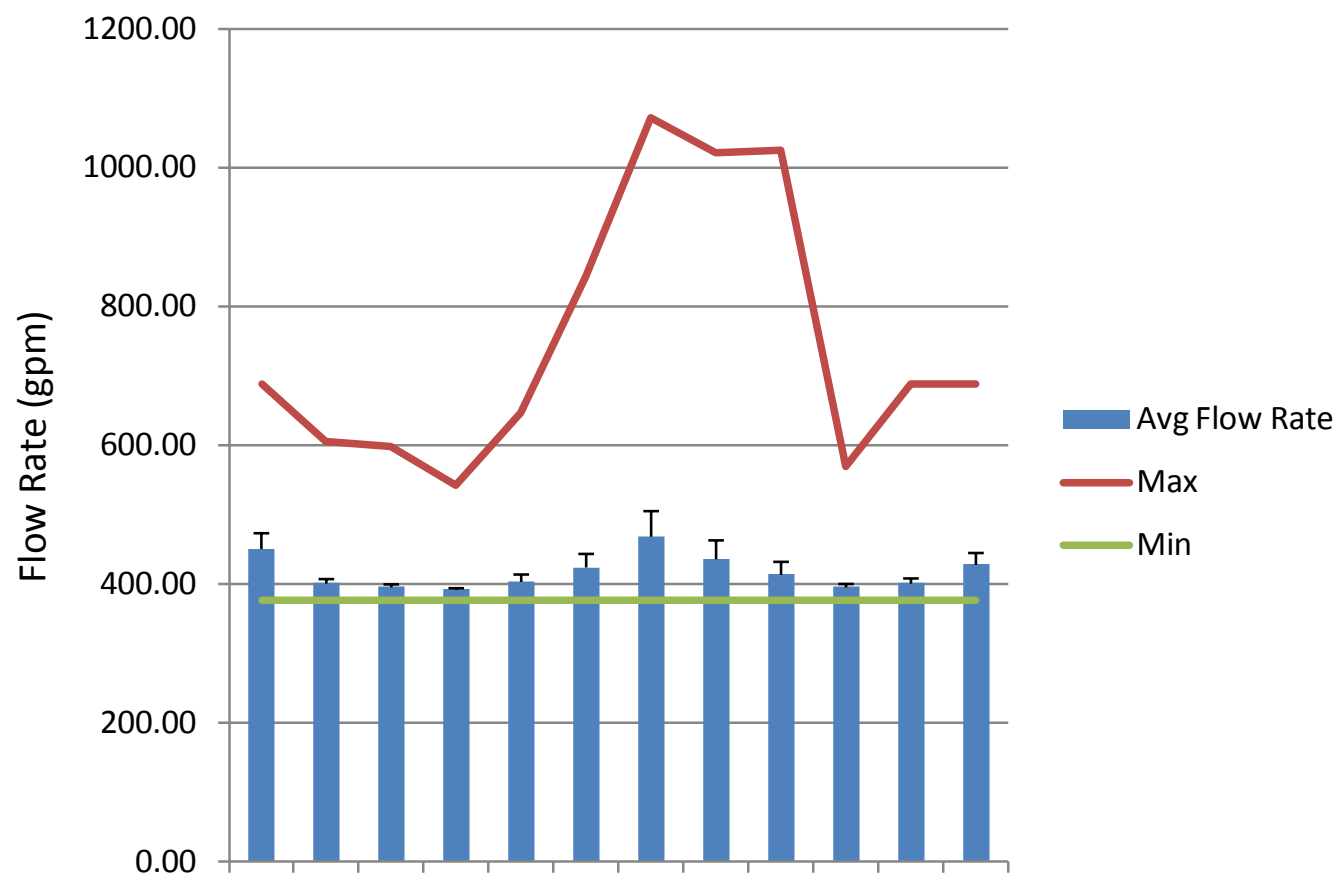

Jan Feb Mar Apr May Jun Jul Aug Sep Oct Nov Dec

Peak Period Definition:

b)

Hourly Pumping Rate $\geq 25 \%$ of 1 Standard Deviation Above

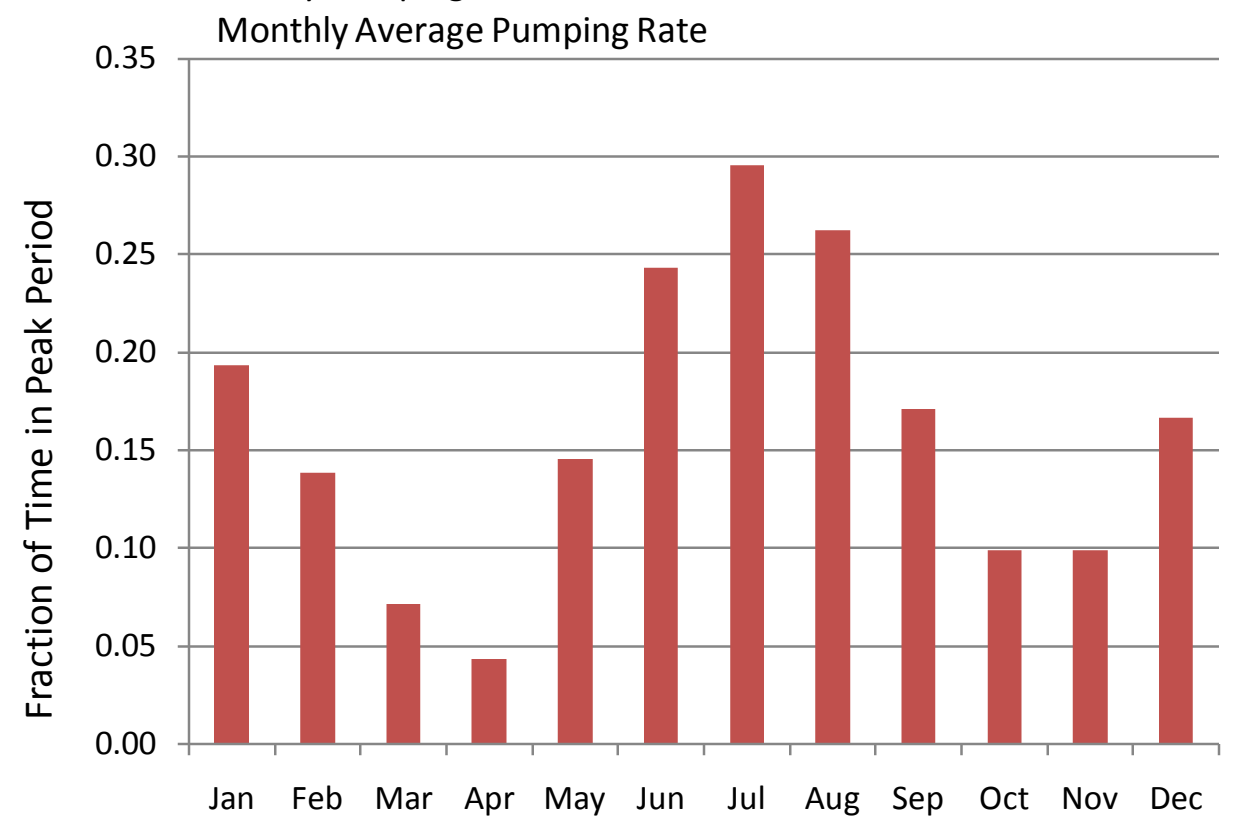

Figure 2.4 a) Average, Minimum and Maximum Flow Rates Through the GSHP with Error Bars Denoting 1 Standard Deviation Above the Mean; b) Fraction of Time Spent in Peak Period 
Figure 2.4b) shows the amount of time the flow rate was identified as a peak as a fraction of the total time in the month. On average, the peak periods occurred only $16 \%$ of the time, with the range varying from 24-30\%. From June to August, the percent of time spent in a peak period ranged from 24-30\%. On a 24-hour basis, this would translate into a peak period range of 5.7 to 7.2 hours. These estimates concur with data from the 30-day test that demonstrates peak periods in February occur from 1 to 5 pm (C. Cataldo, personal communication).

\subsection{Surrounding Plumes}

The BSF/CSF facility is located just south of the Hanford Site. The Hanford Site is a decommissioned nuclear production complex that is operated by DOE. The 300 Area, which is adjacent to the Columbia River and is located $~ 1.5 \mathrm{~km}$ northeast of the BSF/CSF facility, was the site of plutonium production beginning in 1943. Large amounts of uranium and other contaminants were disposed of at the site in liquid waste streams for more than three decades. As a result, uranium contamination persists at this site, but its complex geochemistry and mobility is complicated by diurnal and seasonal fluctuations in river stage (Zachara et al. 2005).

The DOE Horn Rapids Landfill is located $~ 1.2 \mathrm{~km}$ northwest of the BSF/CSF site. Trichlorethylene (TCE) contamination exists in this area and is suspected to be the result of industrial solvent use at AREVA (located to the west of the BSF/CSF site). Solvents were used during installation, cleaning, and repairing of lagoon liners over a 10-year period between 1978 and 1988, which entered the subsurface by spillage. After reaching the groundwater, TCE formed a localized plume that migrated downgradient to the northeast across DOE's Horn Rapids Landfill. The highest concentrations were found near AREVA and DOE's Horn Rapids Landfill. The DOE Horn Rapids Landfill was used in the 1950s to 1970s for asbestos disposal and was closed in accordance with asbestos regulations.

More detailed information on nearby contaminant plumes, including plume maps, can be found in Appendix A. This information was summarized from the Hanford Site Groundwater Monitoring Report for Fiscal Year 2007 (FY07) (DOE/RL 2008).

\subsection{Geology}

A generalized suprabasalt stratigraphic column for the BSF/CSF construction site is shown in Figure 2.5. The stratigraphic column for the upper Ringold Formation and the Hanford formation is based on information obtained from the drilling of 11 boreholes within the footprint of the BSF/CSF construction site during the initial phase of hydrogeologic characterization. Each soil characterization borehole was drilled using the air rotary method. Bulk sediment samples were collected in 7.6-liter (2gallon) buckets held at the end of the cuttings discharge line. Samples were collected at approximately 1.5-meter (5-ft) intervals and at observed changes in lithology. Samples were geologically logged and photographed in the field and then transferred into glass jars and/or plastic bags for archival storage. A detailed description of the samples and geologic conceptual model is provided in Appendix B of this document. 


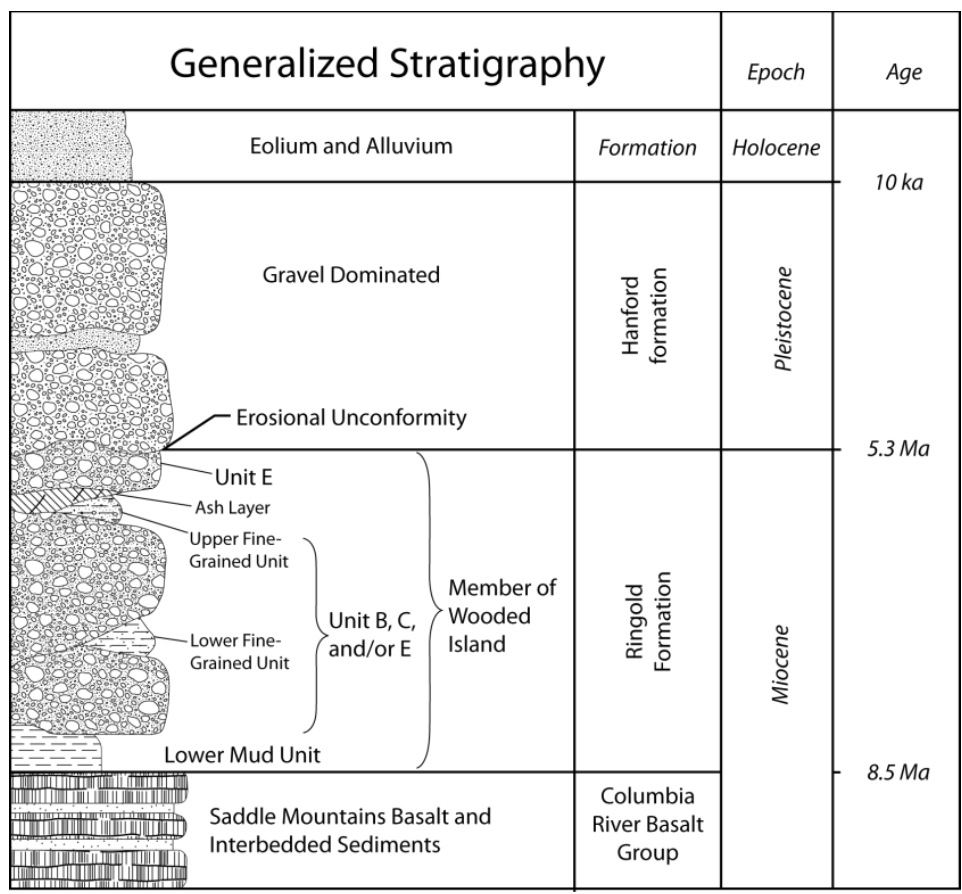

Figure 2.5. Generalized Stratigraphic Column Depicting the Stratigraphy for the BSF/CSF Construction Site. Modified from Reidel et al. (1992), Thorne et al. (1993), Lindsey (1995), Williams et al. (2000), DOE/RL (2002), and Williams et al. (2007).

Additional stratigraphic information was obtained from previously existing geologic logs for nearby irrigation wells, water supply wells, monitoring wells, and characterization borings associated with environmental remediation activities. The uppermost, geologic unit in the study area is the Hanford formation, a highly permeable mixture of sand and gravel that was deposited by the Ice Age floods during the late Pleistocene period. These poorly sorted and unconsolidated sediments generally cover a wide range in size, from boulder-sized gravel to sand, silt, and clay. The BSF/CSF site, which lies at a low elevation adjacent to the Columbia River, received the high-energy floodwaters and is composed almost entirely of gravel-dominated facies of the Hanford formation (Bjornstad et al. 2009).

Beneath the Hanford formation is late Miocene to Pliocene aged sediments of the Ringold Formation. The Ringold Formation is texturally and structurally distinct from the overlying Hanford formation and displays different hydraulic properties. The Ringold Formation contains sands, gravels, and muds that are typically more consolidated and less permeable than those in the Hanford. The Ringold Formation is generally characterized with a lower hydraulic conductivity than the Hanford formation. At the BSF/CSF site, three separate zones have been identified within the Ringold Formation based on the samples collected from the boreholes (Appendix B): a sandy gravel upper subunit, a fine-grained middle subunit, and a lower sandy gravel subunit (Figure 2.6). Beneath the BSF/CSF project site, the aquifer is almost entirely within the Ringold Formation. 


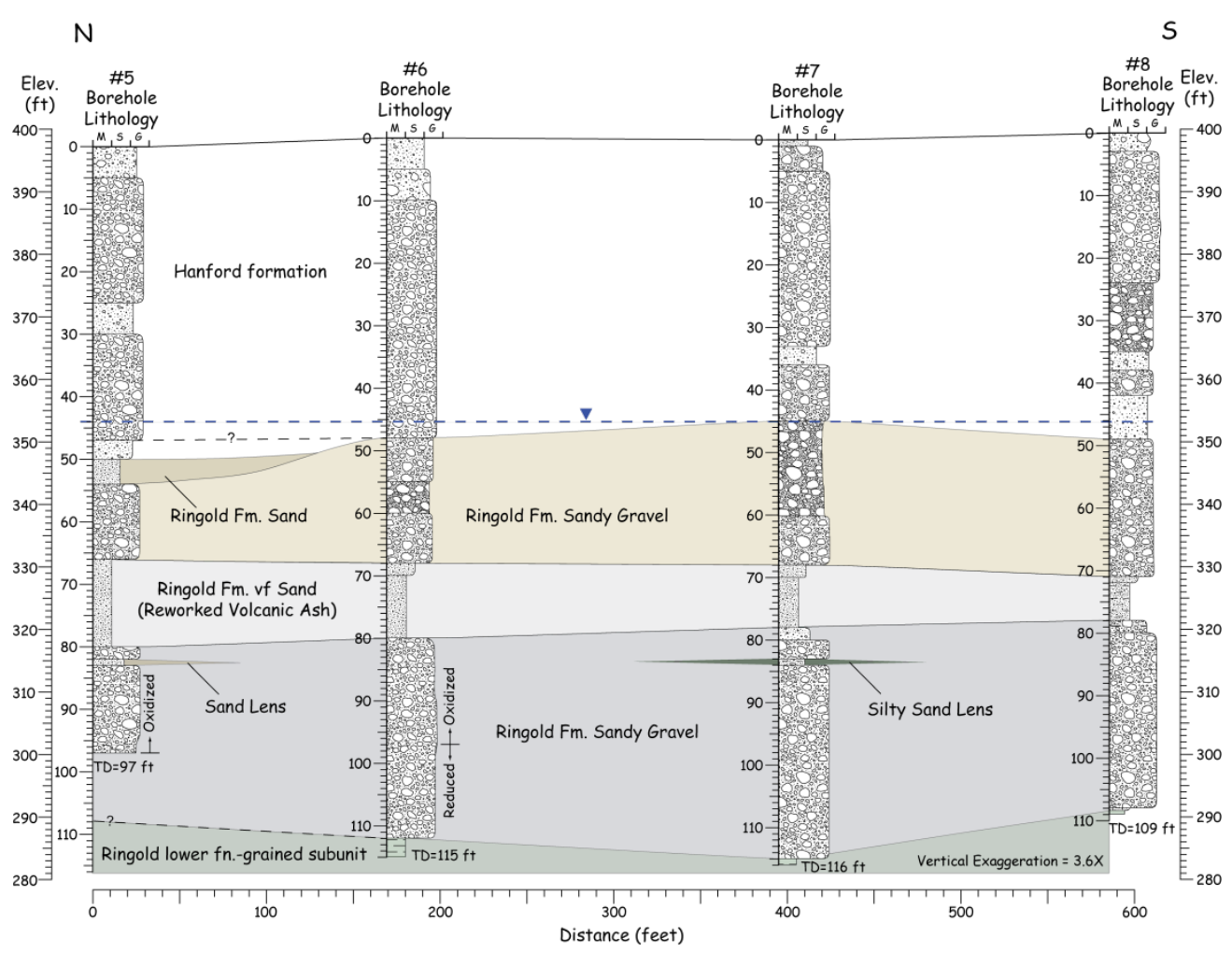

Figure 2.6. Geologic Cross Section Across the East Side of the BSF/CSF Site

\subsection{Hydrogeology}

The general direction of groundwater flow in the North Richland PNNL Campus is east-northeast from the Yakima River to the Columbia River (Figure 2.7 and Figure 2.8). The northeasterly flow direction is likely influenced by the City of Richland recharge ponds, upgradient irrigation, and the Yakima River. In addition, the 300 Area has been shown to be a convergence zone for groundwater flow (Peterson et al. 2005), which may also contribute to the local gradient at the BSF/CSF site.

Field data collected at the site show that the unconfined aquifer is predominantly in the Ringold Formation beneath the BSF/CSF facility, but the saturated Hanford aquifer exists immediately to the east of the site (see Figure 5.4). Field data have also confirmed the existence of a silt layer (particularly on the east side of the site) that may be locally confining, although no measurable differences in head have been found between the upper and lower sandy gravel layers above and below it. 


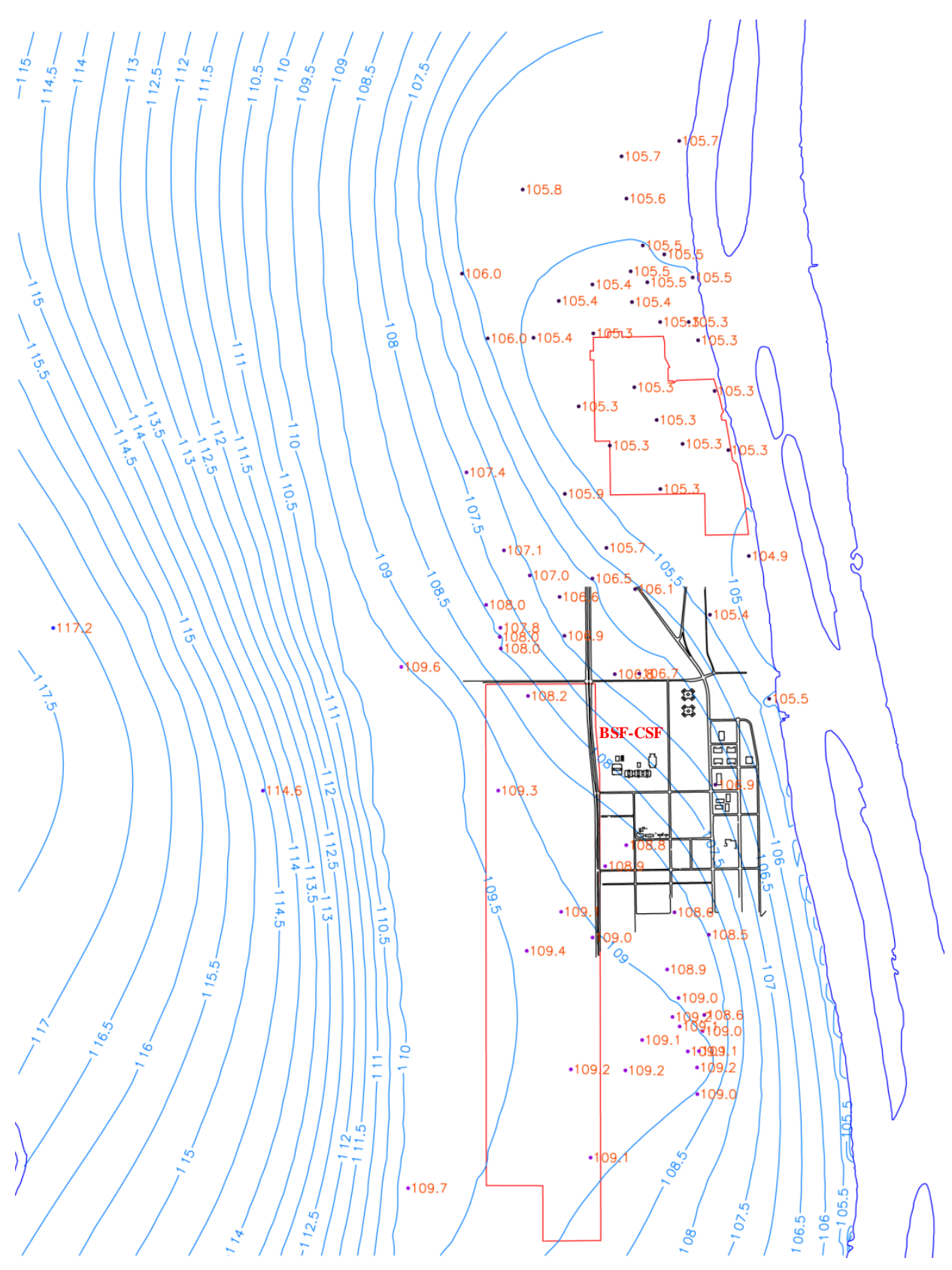

Figure 2.7. Water Table Map, Spring 2006. Water table was constructed using well data from 3/20/06 to 5/26/06, and control points from the water table contour map published in the Groundwater Monitoring Report (Hartman et al. 2007).

The vadose zone consists of unsaturated sediments between the ground surface and the water table. This zone occurs predominantly within sandy gravel, gravelly sand, and silty sandy gravel of the Hanford formation (Newcomer 2007). In some areas, the Ringold Formation extends above the water table into the lower part of the vadose zone. The local thickness of the vadose zone is about 15 meters at the $\mathrm{BSF} / \mathrm{CSF}$ site. In general, the thickness of the vadose zone decreases with proximity to the Columbia River, as the ground surface is sloped toward the river. 


\subsection{Richland Recharge Ponds}

A recharge mound created by the city of Richland's recharge ponds, located near the North Richland Well Field, diverts flow from the west to the northeast and southeast before discharging to the Columbia River. These infiltration ponds are used as a natural filter bed for Columbia River water injected into the subsurface for storage. They also create a hydraulic barrier that prevents groundwater flow from the Hanford Site to the well field. Seasonal operations differ because the water demand is much higher in the summer (30 mgd) than in the winter months (6 mgd). However, a 2:1 recharge to extraction ratio is maintained year round (J. Finch, Water Manager, personal communication, November 2009). Variations in the water table of $\sim 1 \mathrm{~m}$ occur in the well field due to fluctuations in river stage, and differences in the rates of extraction and recharge.

\subsection{Irrigation}

Irrigation of agricultural fields to the southwest has affected groundwater levels seasonally in the area of the DOE Horn Rapids Landfill. The irrigation is supplied primarily by the Columbia River and recharges the unconfined aquifer between the Yakima and Columbia Rivers. Agricultural irrigation began in 1989, but irrigation was expanded in the early 1990s (Liikala 1994).

\subsection{Area}

Groundwater in the unconfined aquifer beneath the 300 Area flows generally to the east and southeast, but a local convergence zone exists in the local region. Flow converges into the 300 Area from regions to the northwest, west, and southwest, and discharges to the Columbia River through the riverbed and to a lesser degree, along the shoreline as riverbank springs. The stage of the Columbia River has a profound effect on groundwater flow patterns and rates in the 300 Area. Seasonal changes in river stage are reflected in water levels measured at wells located as far as inland as 360 meters from the Columbia River (Hartman et al. 2007).

\subsection{Surface Water Features}

The Columbia River is the dominant surface water body adjacent to the BSF/CSF site, located to the east of the site at a distance of $\sim 1 \mathrm{~km}$, with an average flow rate of 120,000 cubic feet per second $\left(\mathrm{ft}^{3} / \mathrm{sec}\right)$ (Waichler et al. 2005). Daily average flows range from 20,000 to $690,000 \mathrm{ft}^{3} / \mathrm{s}$. It originates in the mountains of eastern British Columbia, Canada, and drains a total area of approximately $680,000 \mathrm{~km}^{2}$ en route to the Pacific Ocean. The flow of the Columbia River is regulated by 11 dams within the United States, seven upstream and four downstream from the Site. Priest Rapids is the nearest dam upstream, and McNary is the nearest dam downstream from the Site (Figure 2.8). The Hanford Reach of the Columbia River extends from Priest Rapids Dam to the head of Lake Wallula (created by McNary Dam), near Richland. This reach is the last free-flowing stretch of the Columbia River in the United States above Bonneville Dam. The width of the river varies from approximately $300 \mathrm{~m}$ (984 ft) to 1,000 m (3,281 ft) within the Hanford Site (http://www.pnl.gov/env/Surface water Surveillance.html).

The Columbia River is used as a source of drinking water for onsite facilities and by communities located downstream from the Hanford Site. In addition, the Hanford Reach of the Columbia River is used 
for a variety of recreational activities, including hunting, fishing, boating, water-skiing, and swimming. Water from the Columbia River downstream from the Hanford Site is also used extensively for crop irrigation along its entire length and near the City of Richland.

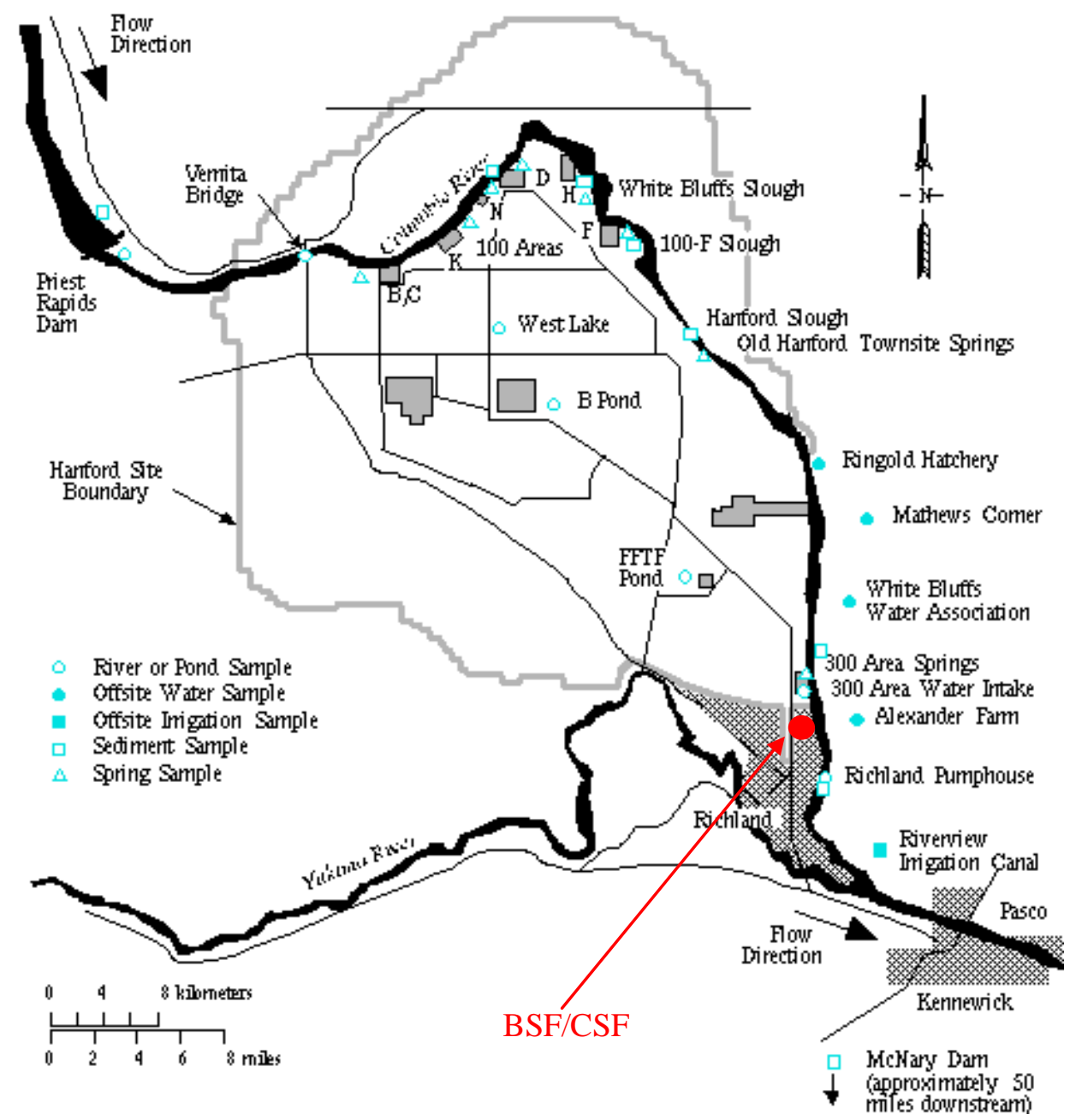

Figure 2.8. Surface Water Features Near the BSF/CSF Site

Water levels in the Columbia River in the vicinity of Hanford vary seasonally because of precipitation and runoff, and daily because of the operation of the Priest Rapids Dam upstream of the Hanford Site. As shown by the 10-year average (1999 to 2008) plotted in Figure 2.9, peak flows generally occur in June and July, with low flows in September and October (http://www.cbr.washington.edu/dart/river.html).

Flow patterns in the zone of groundwater/river interaction are highly variable because of daily and seasonal fluctuations in river stage. River water infiltrates the banks during high stage, moves inland and downward, and subsequently joins the flow of groundwater that discharges through the riverbed (Peterson and Connelly 2001). Hence, discharge to the river is a mixture of groundwater and river water.

Several springs that result from upwelling of groundwater to the surface, also exist on the banks of the Columbia River, though most are seldom flowing or observable (R. Peterson, personal 
communication, December, 2009). The locations of riverbank springs along the Columbia are shown in Figure 2.10. All are located more than $1 \mathrm{~km}$ from the site. With the exception of Spring 43-3, all are located north of regional downgradient flow paths.

The Yakima River is located $\sim 8 \mathrm{~km}$ to the south of the site (Figure 2.8). The Yakima River flows south of the Rattlesnake Hills, but no part of the Yakima River is downgradient from the BSF/CSF site.

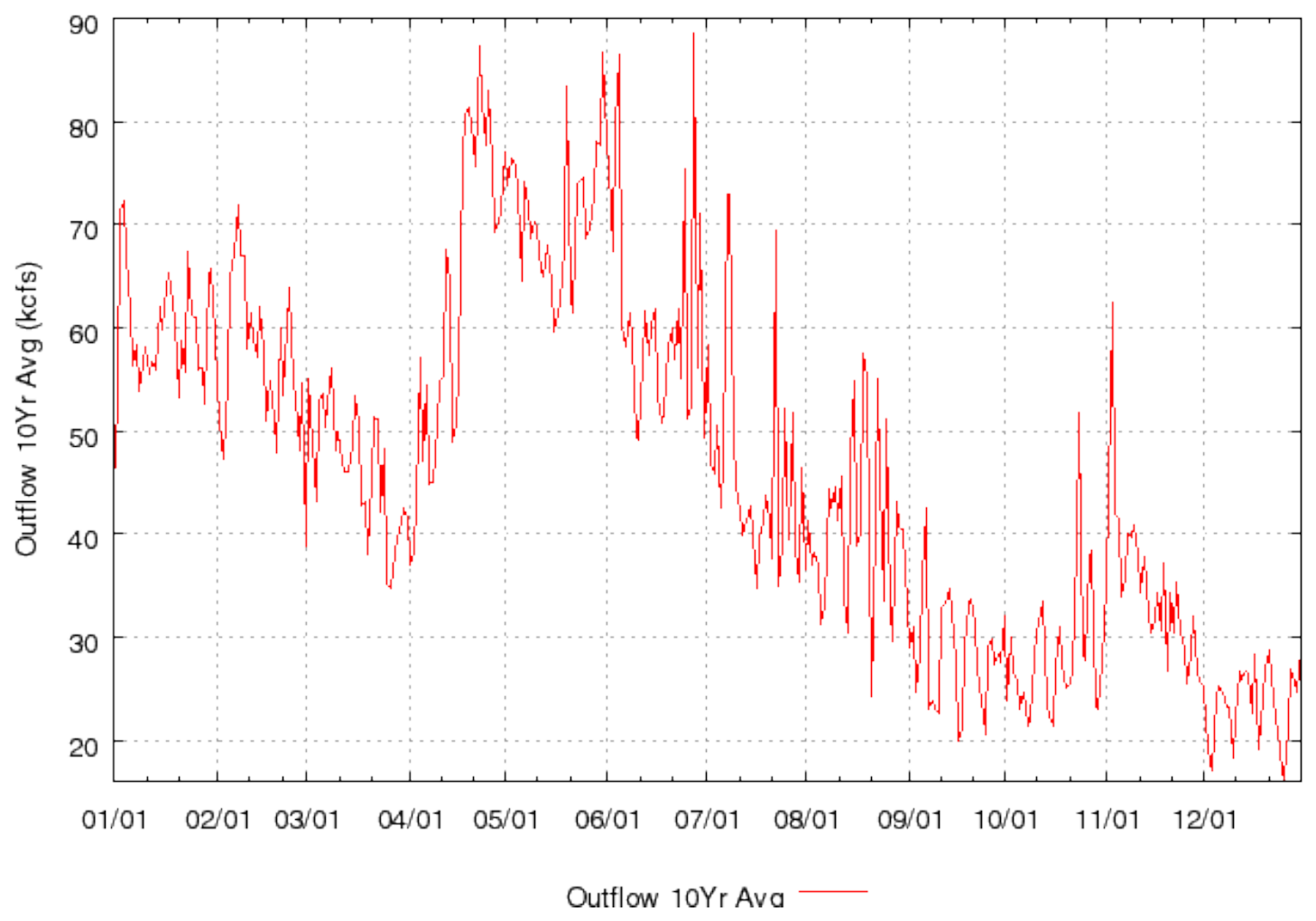

Figure 2.9. Columbia River Outflow 10-Year Average (1999-2008) at Pasco Monitoring Station (PAQW) 


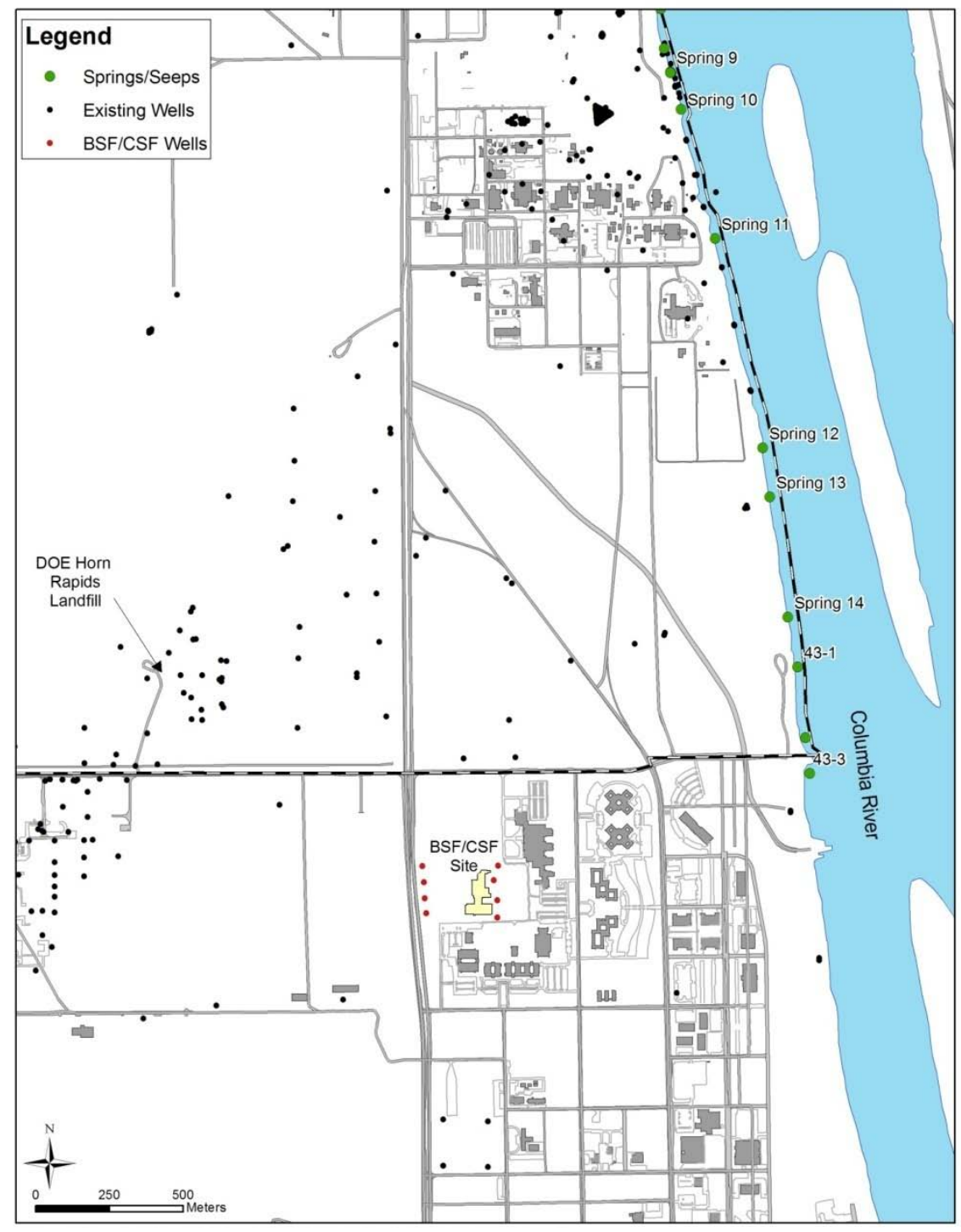

Figure 2.10. Locations of Springs Along the Columbia River

\subsection{Thermal Regime of the Columbia River and Hyporheic Zone}

The temperature in the Columbia River is a complex function of energy inputs including solar radiation and latent and sensible heat transfer. Most variations in the river water temperature are largely dependent upon air temperature and geophysical conditions. Ten-year averages of Columbia River temperatures at the Pasco station (located just south of Richland) demonstrate trends related to air temperature as seen in Figure 2.11 (http://www.cbr.washington.edu/dart/river.html). Temperature fluctuations vary seasonally, and are shown to range from 4 to $20^{\circ} \mathrm{C}$. 


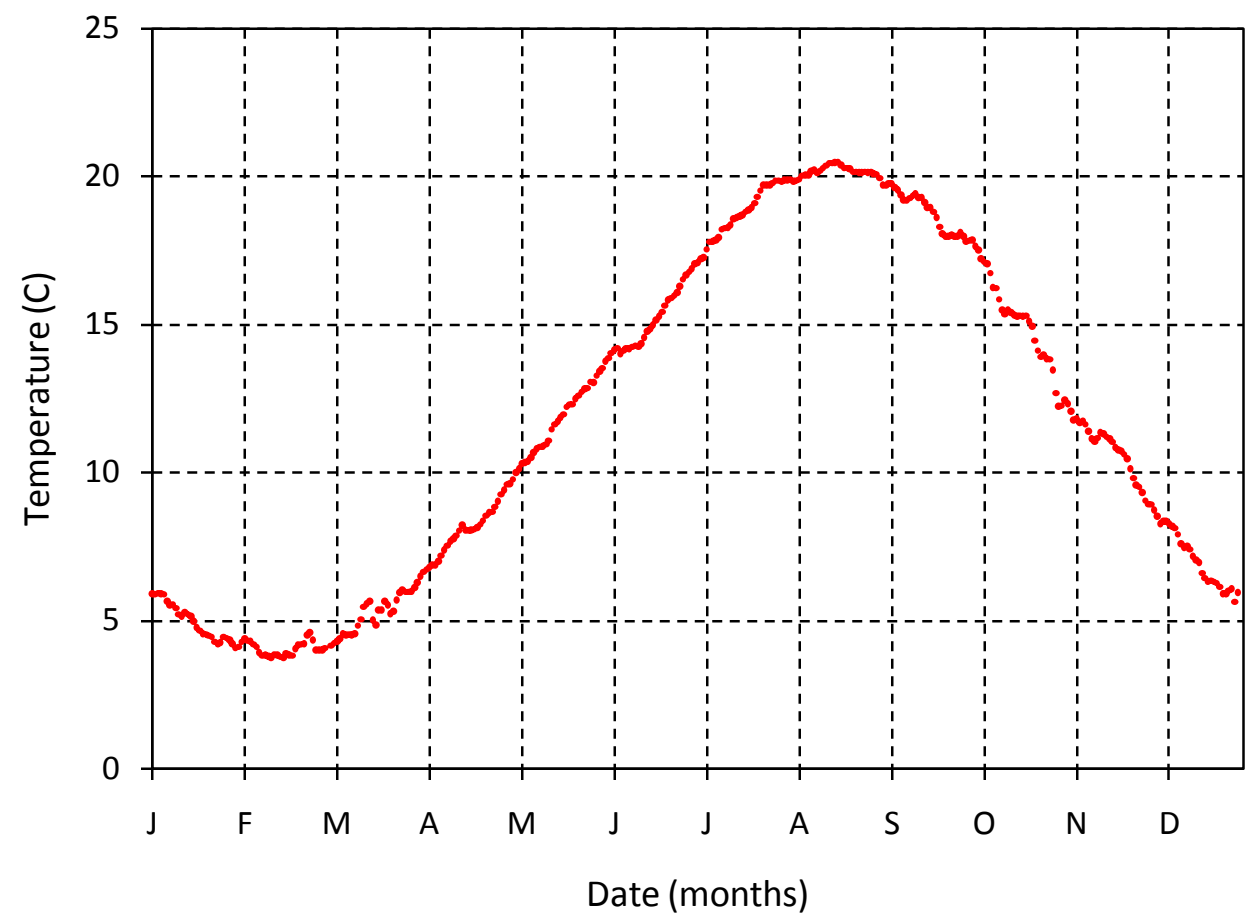

Figure 2.11. 10-Year Average (1999-2008) of Water Temperatures in the Columbia River at the PAQW (Pasco, WA) Station (http://www.cbr.washington.edu/dart/river.html). The average ground water temperature at the BSF/CSF site has been measured in 2009 at $16.4^{\circ} \mathrm{C}$. At the 300 Area, groundwater temperatures average $17^{\circ} \mathrm{C}$ (R. Peterson, personal communication).

In the hyporheic zone, the region beneath and lateral to the river bed, shallow groundwater mixes with water from the Columbia River. In rivers where groundwater inputs are significant, energy input through advection can also be an important control on water temperature. However, the groundwater flux relative to flow in the Columbia is small. For the entire Hanford Reach, a length of 82 km ( 51 miles) along the river shoreline from Priest Rapids Dam to the slack waters of McNary Dam, the total groundwater flux to the Columbia River is estimated at $40 \mathrm{cfs}$ (R. Peterson, personal communication). Average flow in the Columbia River is 120,000 cfs, with daily average flows that range from 20,000 to 690,000 cfs (Waichler et al. 2005). Hence, groundwater flux along the 51-mile Hanford Reach is $0.2 \%$ of the lowest river flow and $0.006 \%$ of the highest flow.

The thermal regime of the hyporheic zone has been reported to be highly spatially and temporally dynamic in the 300 Area, reflecting the complex interaction among climatic, hydrological, morphological and geological conditions (Williams et al. 2008, Fritz et al. 2007). Water temperatures within the hyporheic zones are cooler than the Columbia River in the summer, but warmer than the river in the winter. These trends, which are noted in Figure 2.12, demonstrate a high degree of temporal and spatial variability in temperature at near-shore groundwater monitoring wells in the 300 Area (Williams et al. 2008). During high-river stage periods, river water enters into the aquifer in the near-shore mixing zone, influencing the local groundwater temperature. This influence is noted in wells located more than $190 \mathrm{~m}$ (623 ft) inland. During periods of relatively low-river stage, groundwater discharges to the river (Fritz et al. 2007). Monitoring data collected over several years at sub-hourly time intervals have shown that diurnal temperatures in the hyporheic zone can vary up to $5^{\circ} \mathrm{C}$. 
(a)

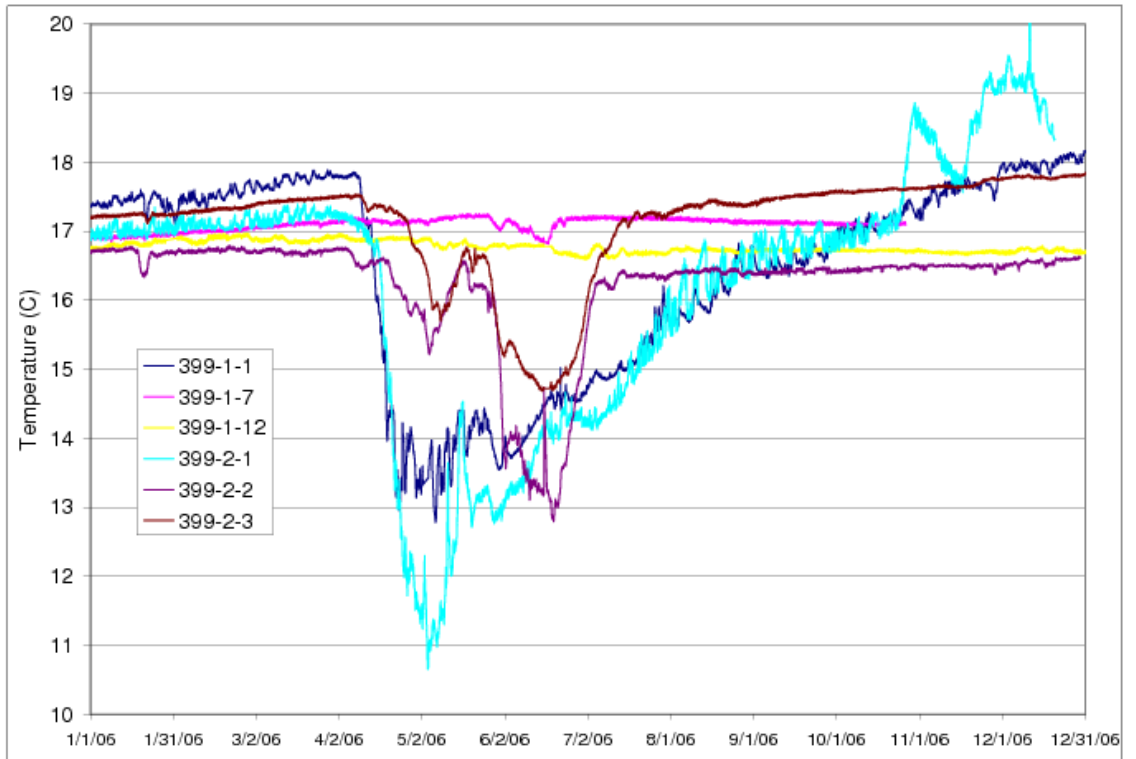

(b)

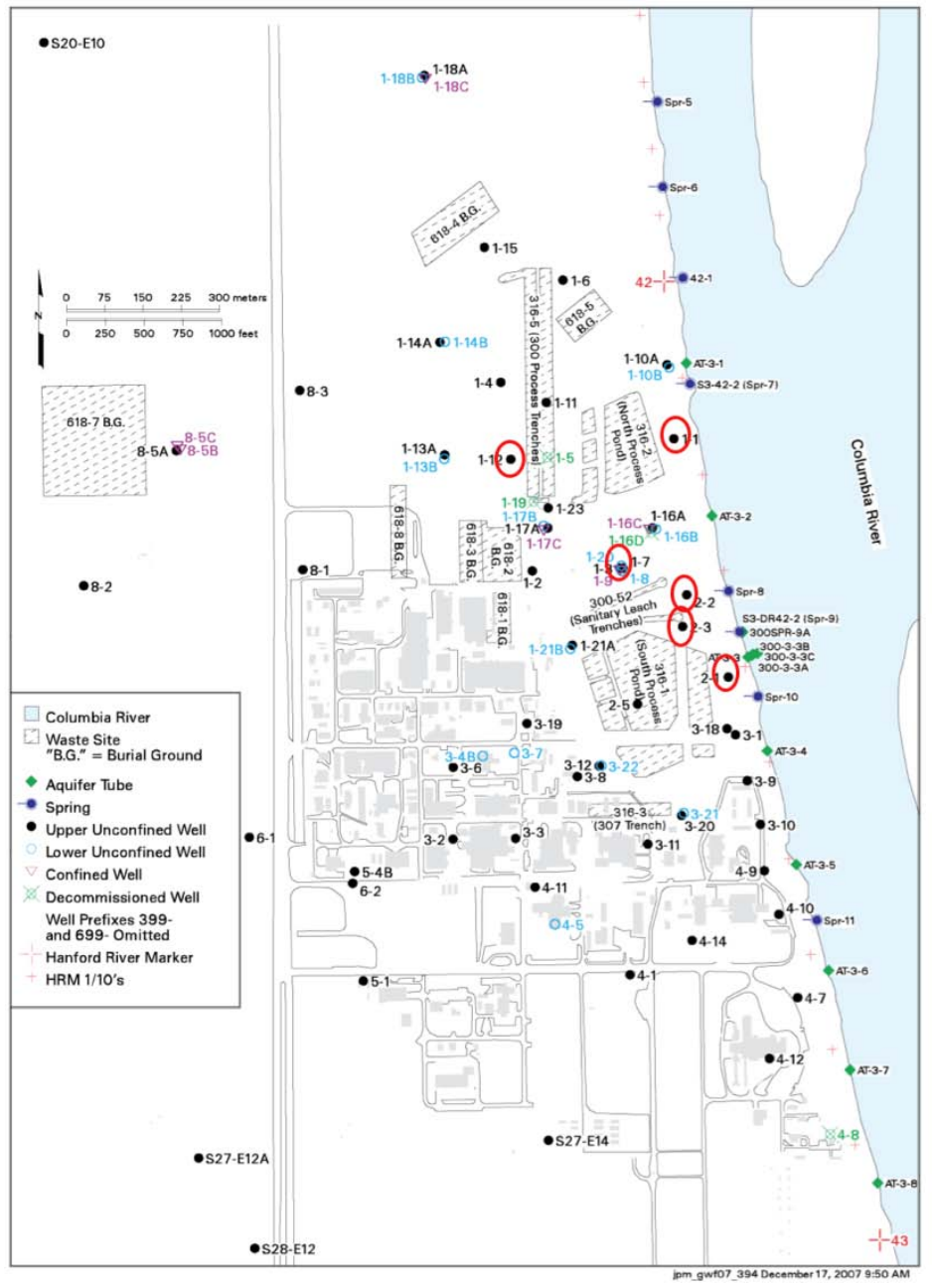

Figure 2.12. (a) Temperatures in the Hyporheic Zone as Measured in 300 Area Wells and (b) 300 Area Well Locations (from Williams et al. 2007) 


\subsection{Production Wells}

At the BSF/CSF site, all wells had to be sited within the BSF/CSF property boundaries. Four wells were drilled on the west side of the property and four wells on the east with an inter-well spacing of 50.8 to $65.5 \mathrm{~m}$ on each side (Figure 2.13). Because initial analyses demonstrated low thermal efficiencies when extraction wells were sited downgradient, extraction wells (Wells 1 to 4) were sited on the western upgradient boundary of the property. Injection wells (Wells 5 to 8) were sited on the downgradient, eastern property boundary. The horizontal distance between wells ranged from 236 to $245 \mathrm{~m}$.

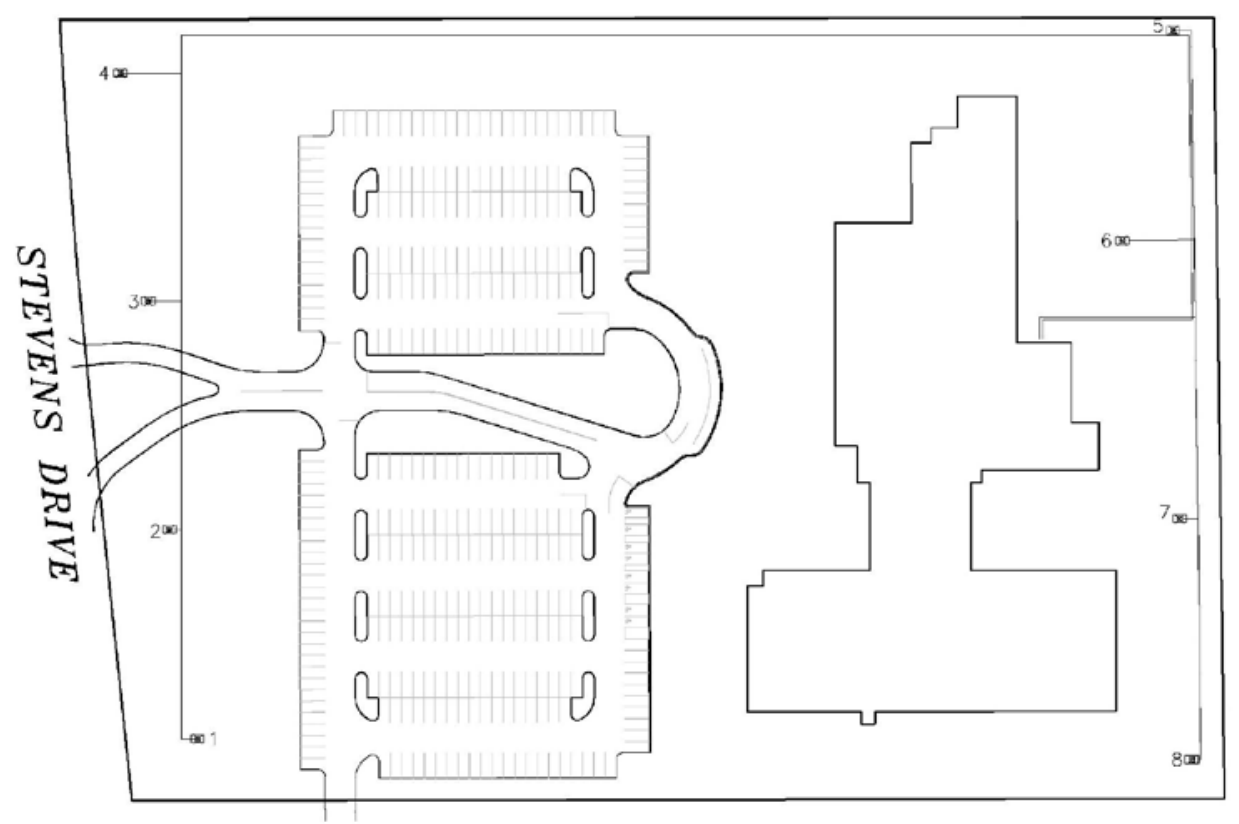

Figure 2.13. Well Locations at the BSF/CSF Site. Extraction Wells Are Located on the West and Injection Wells on the East.

Wells were screened across the coarser-grained zones of the Ringold Formation. Designs included multiple screened intervals to maximize total screen length and yield. Blank sections were placed in the finer grained zones (e.g., silt and fine sand), to avoid pumping of fines in the system. Injection wells have an upper screened interval that extends above the water table several feet into the highly transmissive gravels to increase injection capacity. The as-built diagram for Well 2 is shown in Figure 2.14. As-built diagrams for all other wells are in Appendix C. 


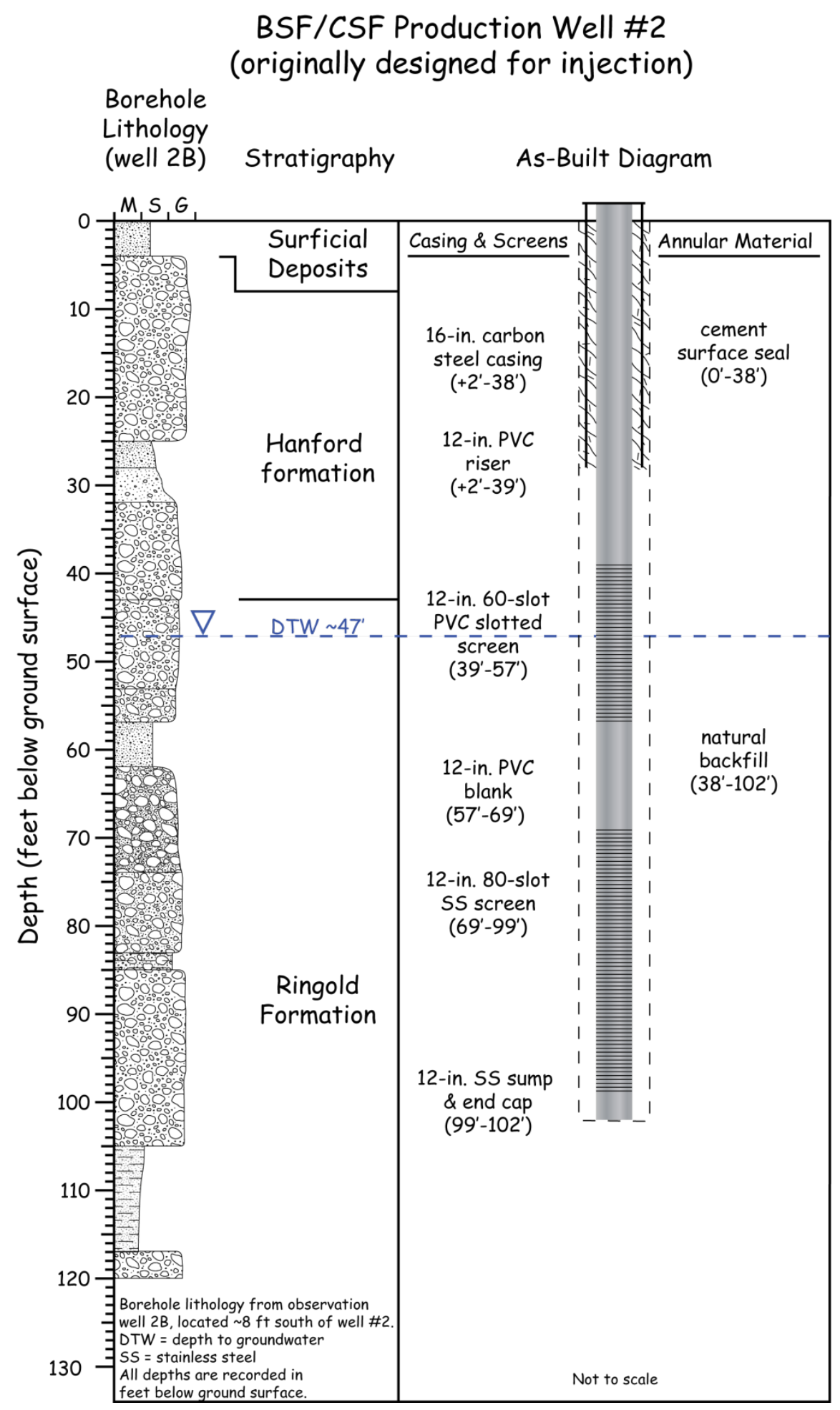

Figure 2.14. Summary of Borehole Log and As-Built Diagram for Production Well \#2 


\subsection{Approach}

As discussed in Section 1, this report documents an analysis of several hydrogeologic and system operating aspects of the GSHP system, including the potential to impact nearby contaminant plumes, the potential to impact neighboring water rights, and the potential to impact the thermal regime of nearby surface water bodies. While valid analytical approaches exist to quantitatively evaluate these questions, a numerical modeling approach is needed to evaluate these questions in three-dimensions.

In addition to assessing groundwater flow directions and velocities, estimates of heat transport are needed to determine potential impacts from the thermal use of the aquifer. Although particle tracking can be used to estimate production well temperatures (Ferguson 2006), this approach does not account for heat transport through solids. Similarly, using the solute transport equation as a surrogate for heat in groundwater flow and transport codes can only account for heat exchange with the solid matrix by setting the appropriate value for solute sorption. While heat conduction is mathematically analogous to solute transport, this approach is only valid if the rate of thermal transport is already known, and the delay in thermal transport can be readily converted to a value for sorption. Changes in temperature due to mixing of ambient groundwater with water heated or cooled by the GSHP are also not easily assessed with this method.

Given the proximity of the BSF/CSF site to the Columbia River and the need to assess the potential of thermal transport to the river, a convective-conductive heat flow simulator was used. The multiphase STOMP (Subsurface Transport Over Multiple Phases) simulator (White and Oostrom 2000, 2006) was developed at PNNL and was selected for this project because of its capability to simulate saturated and unsaturated flow under non-isothermal conditions. The STOMP simulator provides a technically sound approach to analyzing coupled processes of flow and heat transport. However, solving coupled equations for water, air and heat transport likely increases simulation run times (relative to an isothermal groundwater flow simulator such as MODFLOW). This is a cost that limits the number of simulations that can be executed to determine GSHP potential impacts. The approach of this investigation is to demonstrate minimal impact with a high degree of conservatism, which reduces the number of operational scenarios that required simulation.

The STOMP simulator has a variable source code configuration that allows the user to select the appropriate operational mode for the analysis. Operational modes are classified according to the solved governing flow and transport equations and constitutive relation extensions. Hence, for simulations that addressed groundwater flow and transport, the water mode of STOMP (STOMP-W) was used. To address heat transfer issues, the water-air-energy mode of STOMP (STOMP-WAE) was used.

\subsection{Field Hydraulic Characterization}

Apart from developing a conceptual model of the BSF/CSF site, field characterization activities focused on determining the saturated hydraulic conductivity of the Ringold Formation, because the extraction wells on the west side of the property were screened within the Ringold Formation. Pumping tests were conducted in all eight of the BSF/CSF production wells. Step-drawdown and injection tests were used to determine well performance, predict yield, and evaluate injection capacity. Constant-rate withdrawal and injection tests were performed to estimate hydraulic properties of the aquifer. Because 
well screen blanks restricted flow from the middle fine-grained subunit, the hydraulic conductivity estimates were integrated averages of the upper and lower subunits.

\subsection{Sustainability of Pumping Operations}

The issue of sustainable flow was addressed from field characterization activities as well as through the numerical modeling effort. Constant-rate pumping tests were the best indicators of sustained maximum pumping rates. However, multiple wells were not pumped simultaneously, and field tests could not address potential issues of increased drawdown due to well interference and recharge boundary effects from injection wells. The groundwater model, however, could simulate this potential effect, though with some limitations. Specifically, the three subunits within the Ringold Formation are texturally distinct, while hydraulic conductivity field estimates provided only an integrated average. Moreover, the lateral extent of these subunits outside the BSF/CSF site is currently unknown. Hence, the Ringold Formation was represented as a single unit within the model, with a single hydraulic conductivity representative of the entire unit.

A steady-state modeling approach was used to determine potential environmental impacts from the BSF/CSF GSHP. This approach assumes that the magnitude and direction of flow is constant with time throughout the domain. Water-level data in wells plotted with the Columbia River stage show that the water table is not static. In general, water levels correspond to fluctuations in Columbia River stage (Figure 3.1) and vary by $\sim 1 \mathrm{~m}$ for the time period 1991-2008. While these changes may be considered significant for determining sustainable pumping rates at the extraction wells, the changes are small with respect to the overall water table configuration. Water levels in all wells rise when the river stage is high and fall when the river stage is low. While daily and seasonal fluctuations are most strongly pronounced near the river and are smaller in magnitude further inland, Hammond and Lichtner (submitted) have demonstrated near the 300 Area that smoothing (i.e., averaging) of the river stage has a minimal impact on the total water flux to the river from inland areas. 
(a)

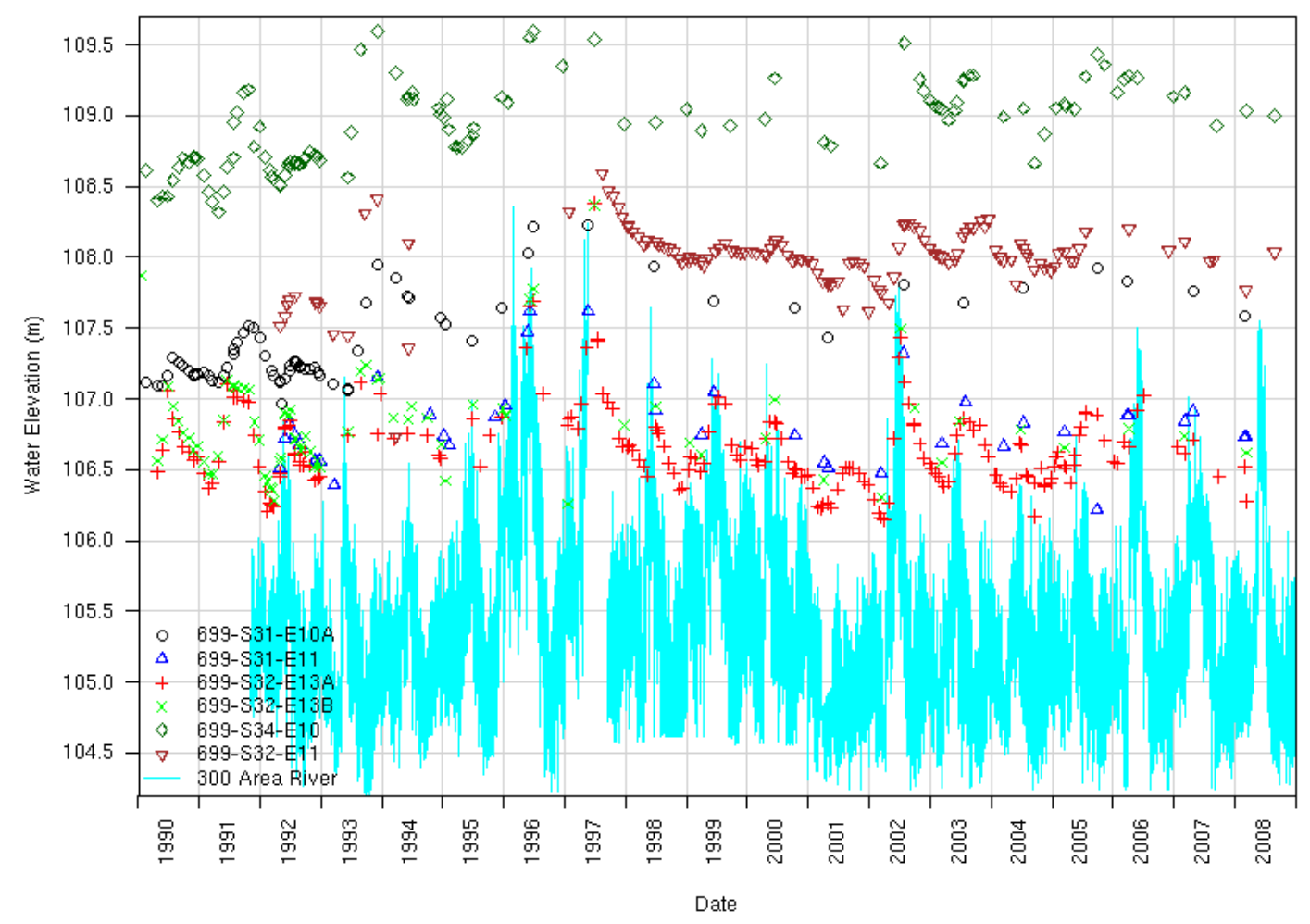

(b)

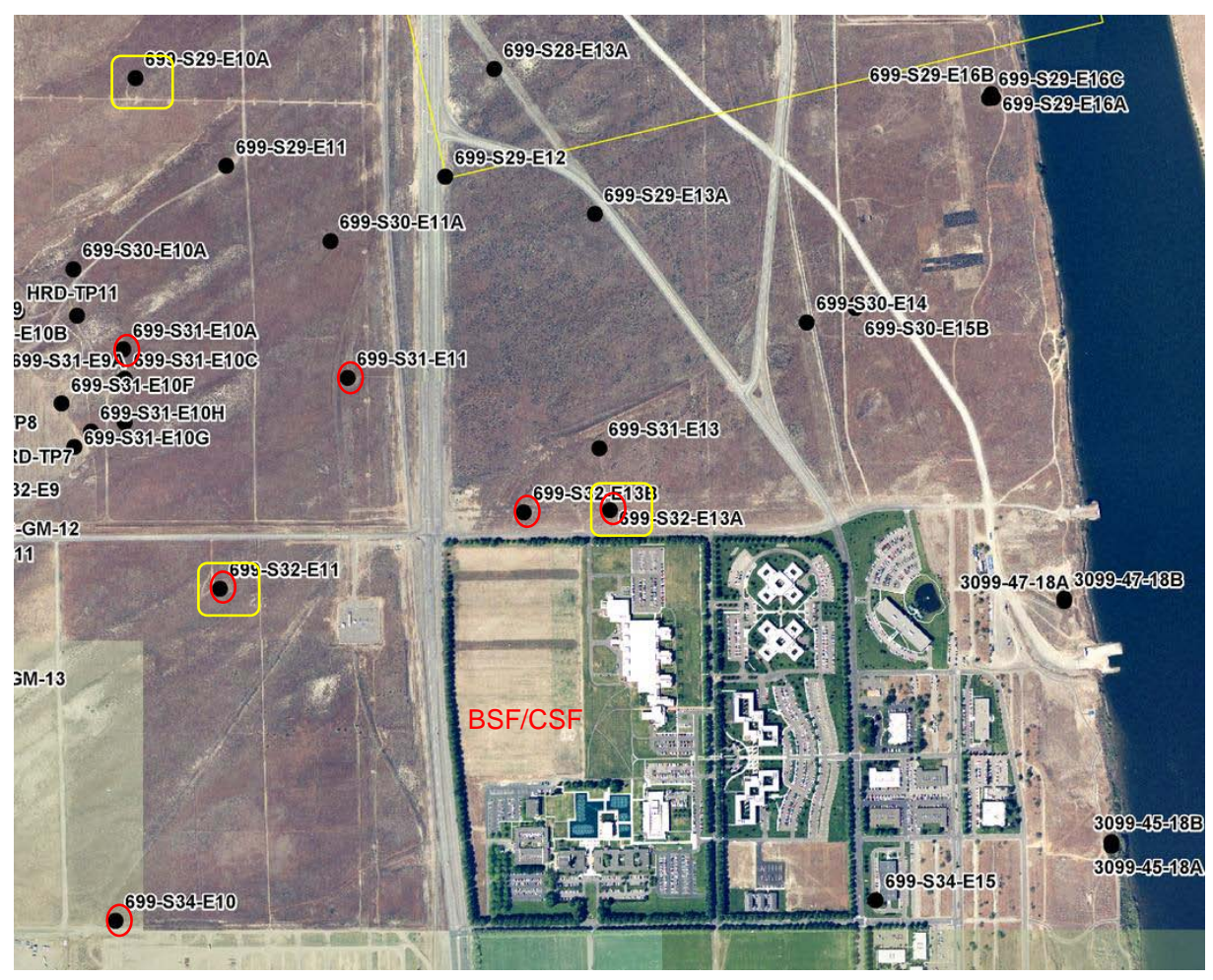

Figure 3.1. (a) Observed Groundwater and River Levels and (b) Well Locations. Well locations marked in red are plotted in (a). Well locations marked in yellow were used in the triangulation presented in Figure 3.2. 
The capture of this transient flow behavior near the river is important for contaminant transport analyses, where a fluctuating water table can mobilize and re-mobilize contaminants in the vadose zone. This transient behavior would also likely attenuate groundwater temperatures near the river since river water mixes with the groundwater. By assuming a steady-state flow regime, temperature impacts simulated at the river are likely conservative since groundwater mixing with the river water is ignored.

Transient groundwater flow directions were also examined using triangular interpolation of hydraulic head data from three monitoring wells (see Figure 3.1b). The three wells selected for analysis are near the BSF/CSF site, have similar frequency and synchronization of manual water level measurements, and are completed in similar zones of the unconfined aquifer. Results of the triangulation, presented in Figure 3.2, show that the gradient varies from 0.001 to $0.002 \mathrm{~m} / \mathrm{m}$. The northeasterly flow direction varies somewhat during river stage changes, but the average direction is 50 degrees east of north. More importantly, at the BSF/CSF site, no reversal of flow directions occurs due to fluctuations in the river stage. The gradient is sufficiently steep and the wells far enough away from the river to prevent any reversals in flow gradients. In the 300 Area, evidence of flow reversals occurs only in wells that are located less than $200 \mathrm{~m}$ from the shoreline (Williams et al. 2008).

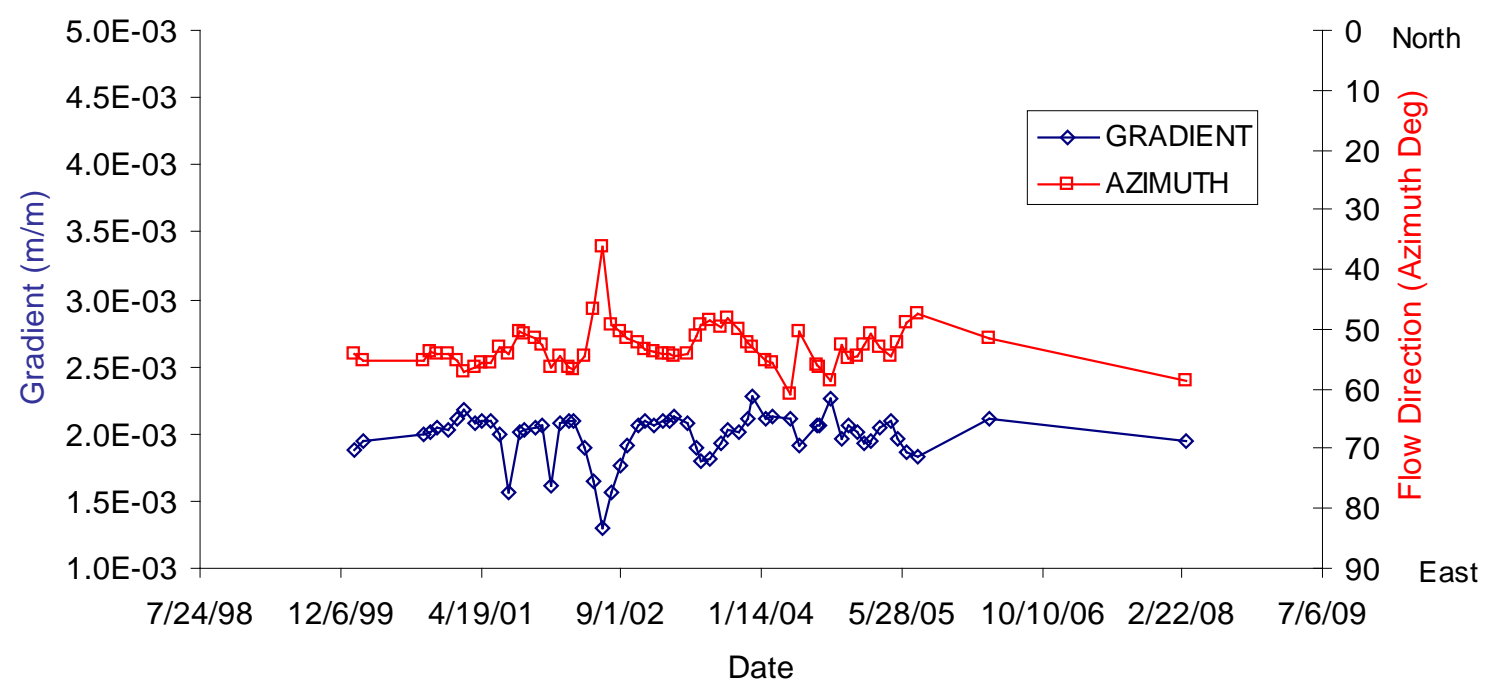

Figure 3.2. Groundwater Gradient and Flow Direction Based on Triangulation of Manual Water Level Measurements from Wells 699-32-Ell, 699-S29-E10, and 699-S32-E13A

The steady-state flow field was calibrated to an average groundwater table configuration. Even though an abundance of data exists for the Hanford Site and are published in annual groundwater monitoring reports (e.g., Hartman and Rediker 2009, Hartman and Weber 2008, Hartman et al. 2007), considerably less data are available in the vicinity of the BSF/CSF site. A spring water table based on 2006 data was used. Given the availability of this data, and the uniform impact of river stage on water levels at the BSF/CSF site, this static water table configuration was used to assess potential impacts. 


\subsection{Radius of Influence}

An important issue within a regulatory framework is to determine the radius of influence for the GSHP well system. For most sites, the radius of influence is used only to determine the potential to impact others holding water rights nearby. At the BSF/CSF site, this radius of influence was important to assess environmental impacts as well to determine the potential to draw nearby contaminants into the well system. A common definition for the radius of influence is the extent of drawdown to some small but practical value. However, the definitions of small and practical may be at odds with each other. For example, (small) centimeter-level drawdowns can be estimated using either analytical or numerical solutions, but these estimates may not be realistic (practical) thresholds when considering the uncertainty associated with a conceptual model and the parameterization of that model. Moreover, this method does not take into account the magnitude of the regional gradient. At the BSF/CSF site, cm-level drawdown may be predicted at some distance by the flow model, but the gradient toward the river is still larger than the gradient toward the well. This means that flow trajectories toward the river are unchanged, and the drawdown "cone" is not necessarily representative of the fate of water in the flow system.

Given that two separate impacts need to be assessed (infringement on existing water rights holders and negative impacts to nearby contaminant plumes), different methods for determining the radius of influence are presented. The radius of influence at the BSF/CSF site is determined not by an absolute measure of predictive drawdown alone, but by assessing a drawdown cone in conjunction with changes in flow paths. The flow field from the numerical groundwater model was used because analytical solutions were considered inadequate for drawdown predictions at the BSF/CSF site. Using particle tracking, which was performed using customized code developed under the $\mathrm{R}$ software environment $(\mathrm{R}$ Development Core Team 2008), flow paths with and without pumping wells were plotted together so that significant changes in flow paths could be assessed. . Because this metric is qualitative, a capture zone analysis was also performed to assess changes in flow path trajectories between the BSF/CSF facility and the Columbia River arising from GSHP operations. This was accomplished by systematically releasing particles to the north (and south) of the extraction wells at increasing distances. The furthest particles captured at the well were used to identify the capture zone. This approach more accurately reflects the potential impacts on contaminant plumes since small scale drawdown may actually lengthen current contaminant trajectories, and the direction of steepest descent may still be toward the Columbia River.

\subsection{Thermal Plumes}

A conservative approach to assessing thermal impacts is attractive because it can minimize the scope of the assessment. If minimal impact can be demonstrated with conservative assumptions, then predictions of thermal transport that represent less conservative scenarios are not required. Conservatism from a regulatory viewpoint is also desirable due to the uncertainty associated with any model prediction.

In this thermal transport analysis, conservatism is assumed due to uncertainties associated with the conceptual model and its parameters. Because heat is predominantly transported by the groundwater, the uncertainty associated with thermal conductivity is considered to be considerably less than the conceptual model uncertainty. The use of a steady-state flow model applies a high degree of conservatism to the analysis. Small variations in flow paths due to small-scale fluctuations in the water table are not accounted for here. This would impact thermal transport by increasing the spreading of the thermal plume, effectively decreasing temperature impacts because more ambient groundwater mixes with the 
water injected into the subsurface. With a static river boundary, mixing of groundwater and river water is also not accounted for in the hyporheic zone. This is a highly conservative assumption, given that the daily temperatures at the shoreline have been shown to vary up to $5^{\circ} \mathrm{C}$ (Fritz et al. 2007).

Monthly pumping rates and injection temperatures were obtained from the building simulation program that was applied to the BSF/CSF facility (Table 2.1 and Table 2.2). These rates are conservative, inasmuch as they assume that pumping occurs 24 hours per day, 7 days per week, whereas the system is not expected to operate continuously. Since continuous heat rejection is expected once the facility is fully equipped in 5 years, this long-term operational scenario is presented for evaluating the water right.

Two different simulation scenarios were executed and collectively analyzed. One simulates the monthly average conditions for pumping rates and injection temperatures, and the other considers peak conditions. Although peak conditions need to be included to fully assess potential environmental impacts, analyzing average-only conditions provides a highly conservative estimate of the lower bound on potential impacts, as well as an opportunity to identify impacts from peak operating conditions.

In this analysis, it is assumed that the pumps are not operational for two months during the year. This assumption was made for the coldest months of the year, January and December because the GSHP will not operate at temperatures below $7.2^{\circ} \mathrm{C}\left(45^{\circ} \mathrm{F}\right)$ (see Section 2.1.1). Hanford meteorological data presented in Section 2.1.1 shows that the number of months per year with temperatures below this threshold ranges from 3.7 to 5.0 months. Hence, two months is a conservative time estimate for the pumps to not be operational in this analysis.

Although peak periods typically occur for 6 hours (see Section 2.1.2), it is conservatively assumed that peak periods occur for a period of 12 hours. To simulate two monthly peaks, the 12-hour periods are assumed to occur consecutively so that one full month of peak pumping rates and injection temperatures is simulated in the month of July $\left(1900 \mathrm{gpm}, 19.9^{\circ} \mathrm{C}\right)$. Average conditions are considered for the other months in the year using injection temperatures that are $2.5^{\circ} \mathrm{C}$ above ambient $\left(16.4^{\circ} \mathrm{C}\right.$ ) (see Table 2.1). 


\subsection{Field Characterization}

\subsection{Hydraulic Conductivity Estimates}

Most nearby estimates of Hanford formation hydraulic properties come from the 300 Area where several hydrogeologic field investigations have taken place over the years. At least three efforts (Swanson 1992, Schalla et al. 1988, Williams et al. 2007) were made to conduct aquifer tests, but only the first two performed a constant-discharge pumping test. The last study used depth-discrete slug tests, which sometimes provide less representative estimates for the large-scale hydraulic properties of the aquifer. Estimates of saturated horizontal hydraulic conductivity (K) in the Hanford and upper Ringold Formations range from 2 to 15,200 m/d.

A series of pumping tests were performed in order to obtain aquifer properties for the site and evaluate well performance. Each of the $8 \mathrm{BSF} / \mathrm{CSF}$ production wells was tested with step and constantrate tests. Extraction wells (Wells 1-4) were tested using withdrawal (drawdown) of water, and injection wells (Wells 5-8) were tested using injection of water (buildup) in accordance with the system design.

The constant-rate test in Well 2 benefited from having the most ideal test conditions of all the tests performed. It consisted of a 60-hour constant-rate pumping withdrawal followed by a recovery monitoring period of 100 hours. For the test in Well 2, aquifer responses were observed in a greater number of observation wells located over a range of radial distances and multiple orientations to the stress well. Tests in the other seven BSF/CSF production wells had 24-hr durations and were monitored with one or two observation wells located about 180 feet from the stress well along the same orientation. For these reasons, the hydraulic test results from the test in Well 2 are considered the most defensible estimates of the local-scale hydraulic conductivity of the upper Ringold Formation and are discussed below. Results from hydraulic testing in the other seven BSF/CSF production well provide additional information on geologic heterogeneity and the range of hydraulic properties. These additional results are discussed in Appendix D.

\subsubsection{Results from Constant-Rate Pumping Test in Well 2}

Based on the results from the step-drawdown tests in Well 2, the constant-rate test was run at a sustainable flow rate of 400 gpm. The flow rate required adjustment during the first few hours of the test, but it was very stable thereafter and did not vary by more than $5 \%$ during the test, which allowed for a reliable analysis of the drawdown data. As noted above, four observation wells were used to monitor the pressure response of the test and estimate aquifer hydraulic properties. The radial distance of these wells from the pumping well varied between $2.4 \mathrm{~m}(8 \mathrm{ft})$ and $52 \mathrm{~m}$ (170 ft), with two observation wells having the same radial distance of $9 \mathrm{~m}(30 \mathrm{ft})$.

Hydraulic properties were estimated using a type-curve fitting method according to the analytical solution of Neuman (1972, 1974, and 1975) for an unconfined aquifer with delayed gravity response (specific yield). The analysis also assumes the aquifer is homogeneous, of infinite areal extent, of uniform thickness, and ignores well-bore storage effects. Note that Well 2 (as well as other BSF/CSF production wells) is screened within two different permeable coarse-grained zones of the upper Ringold formation (Figure C.2). The fine-grained sediments that separate the two gravelly zones of the aquifer were blanked off with casing in order to minimize silt and sand pumping into the system. The strict 
assumption of a single homogeneous unconfined aquifer in the analytical solution is not fully satisfied because of the compound-screen design of the stress well and the layered nature of the aquifer formation. Hydraulic conductivity $(\mathrm{K})$ values were calculated from the analytically-derived transmissivity $(\mathrm{T})$ estimates using a prescribed saturated thickness (b) of 18 meters ( 60 feet) according to $\mathrm{T}=\mathrm{K} / \mathrm{b}$. This represents the average saturated thickness between the water table and the bottom of the unconfined aquifer (Ringold lower fine-grained subunit) at the BSF/CSF site (Figure B.2). Storativity (S) and specific yield (Sy) were prescribed to values of 0.001 and 0.2 to 0.25 , respectively. The aquifer consists of layered sediments of contrasting lithology and would be expected to have differences in vertical and horizontal hydraulic conductivity. However, using an anisotropy value $(\mathrm{Kz} / \mathrm{Kr})$ of 1.0 resulted in an improved model fit of the early and intermediate-time data and did not result in a significant difference in the estimated transmissivity $(\mathrm{T})$.

Type-curve fits were made to the drawdown data in three of the four observation wells (Figure 4.1) since one of the wells exhibited an increasing drawdown derivative trend. This response may be related to non-ideal test conditions such as turbulent flow toward the pumping well or cascading water associated with a long screened interval. Based on the results of the drawdown data for the constant-rate pumping test in Well 2, the saturated hydraulic conductivity (K) of the gravel-dominated test interval in the upper Ringold Formation was estimated to range from 66 to $122 \mathrm{~m} / \mathrm{d}$ (average $86 \mathrm{~m} / \mathrm{d}$ ) (Figure 4.1). Saturated K estimates obtained from subsequent constant-rate pumping (withdrawal) tests in the other three $\mathrm{BSF} / \mathrm{CSF}$ extraction wells on the west side of the site show a wider range in K estimates but are generally similar (Appendix D).

The K estimates from the constant-rate test in Well 2 provide a local-scale estimate of the upper portion of the Ringold Formation. The complex depositional environment and erosional history of the hydrogeologic layers create significant spatial heterogeneity. Selecting a single defensible K estimate to represent the Ringold Formation within the entire modeling domain is challenging and introduces an unknown amount of uncertainty. Based on field data at the BSF/CSF site and the range of hydraulic properties reported by others in the 1100 and 300 Areas (Appendix D), demonstrates that a range of K values exists for the site. Providing a range of $\mathrm{K}$ values more fully addresses hydrogeologic uncertainty. For example, if the aquifer thickness is less than what was assumed in this analysis, then the $\mathrm{K}$ values are higher than the reported values. Hence, saturated hydraulic conductivity estimates of 60 and $150 \mathrm{~m} / \mathrm{d}$ are consistent with the range of probable and observed Ringold Formation estimates in BSF/CSF production wells using both drawdown and recovery data (see Appendix D). 

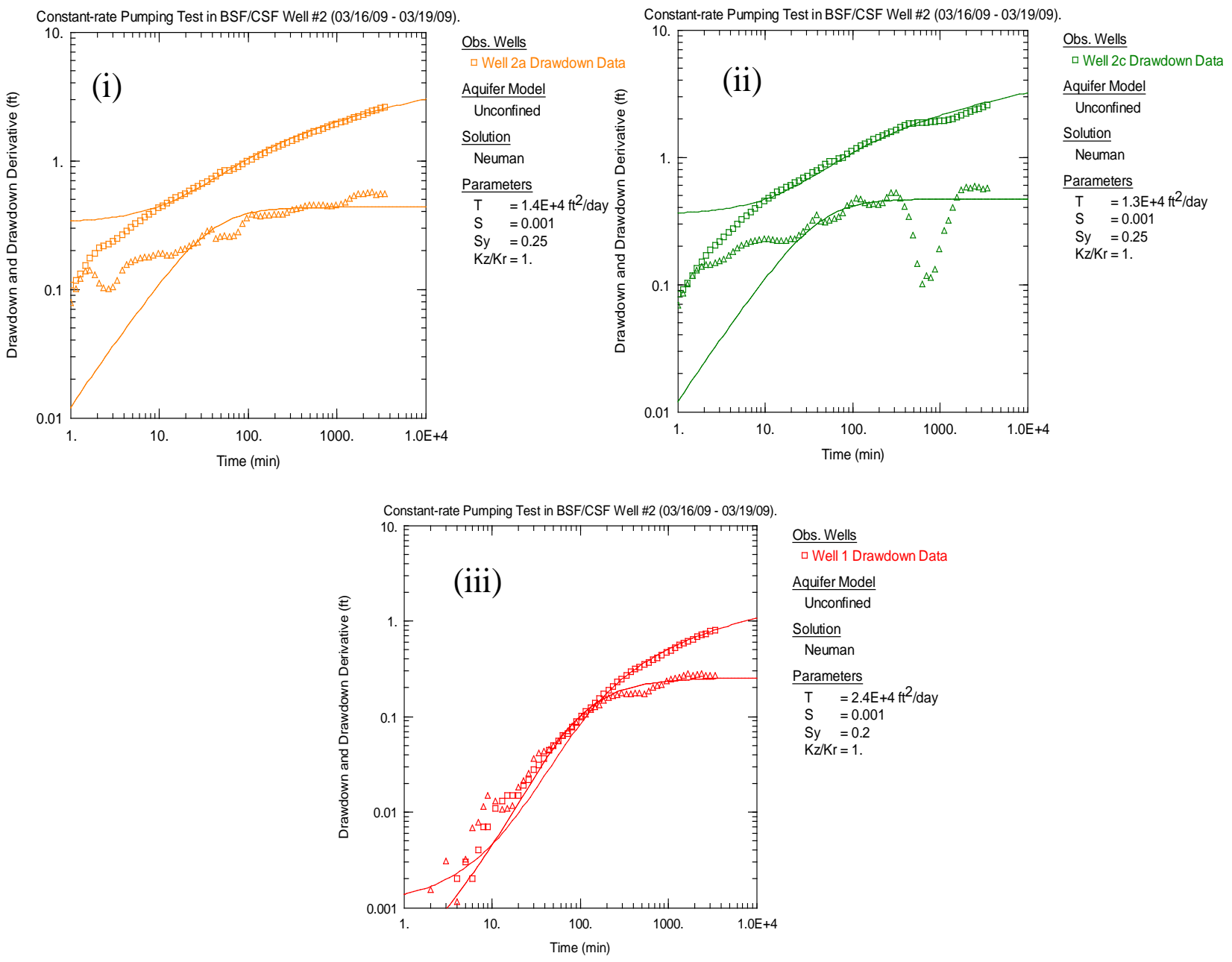

Figure 4.1. Neuman $(1972,1974,1975)$ Type-Curve Fits to the Drawdown (boxes) and Derivative (triangles) for Wells 2a (i), 2c (ii), and 1 (iii) for the Constant-Rate Withdrawal Test In Well 2 


\subsection{Sustainable Pumping Rates}

Sustainable pumping-rate estimates are based on the results of the step- and constant-rate well pump tests (see Appendix C). The results of these tests have confirmed that the aquifer exhibits heterogeneity, in particular, at Wells 2, 7, and 8. Sustainable pumping rates for extraction wells 1, 2, 3, and 4 are estimated at 600, 400, 100, and $300 \mathrm{gpm}$, respectively (1400 gpm total). Maximum short-term pumping rates are estimated at 700, 600, 200, and 400 gpm, respectively (1900 gpm). Given that injection will mostly occur in the upper sandy gravel unit of the Ringold and mound into the Hanford formation, injection rates will likely only be limited by maintenance issues such as well-screen plugging.

\subsection{Groundwater Samples}

As discussed in Section 2.2, there are existing groundwater contamination plumes in the vicinity of the BSF/CSF site. As part of the initial characterization of the groundwater, three water samples were taken during aquifer testing of Well \#1 and Well \#2. The samples were collected and analyzed in accordance with internal PNNL procedures and quality assurance planning requirements and according to the Clean Water Act analytical methods of 40 Code of Federal Regulations, Part 136, "Guidelines Establishing Test Procedures for the Analysis of Pollutants.”

One sample was taken during the aquifer test for Well \#1 (September 2008). Two water samples were taken at the beginning and at the end of the aquifer test for Well \#2 (March 2009). General chemistry parameters, including anions, cyanide, metals and volatile organics, were analyzed by Columbia Analytical Services (Washington State Laboratory Accreditation \#C1203) located in Kelso, Washington. Radionuclide analyses were performed by PNNL's Radiochemical Processing Laboratory (RPL) located in the 300 Area of the Hanford Site. Table 4.1 lists the requested analytes and the analytical methods. The analytes were selected from Chapter 173-200, Washington Administrative Code, "Groundwater Quality Criteria,” and constituents of concern as identified in surrounding contaminated sites.

Table 4.1. Analytes and Analytical Methods

\begin{tabular}{lc}
\hline Analytes (WAC 173-200) & Analytical Method \\
\hline $\mathrm{pH}$ & 4500 \\
Conductivity & SM 2540 C \\
Cyanide (Total) & SM 4500-CN-E \\
Chlorides & 300.0 \\
Fluoride & 300.0 \\
Nitrite (as N) & 300.0 \\
Nitrate (as N) & 300.0 \\
Orthophosphate (as P) & 365.3 \\
Sulfate (as SO, & 300 \\
Total Dissolved Solids (TDS) & SM 2540 C \\
Metals (Total): Ba, Be, Cd, Ca, Cr, Co, Cu, Fe, & 200.7 \\
Mg, Mn, Ni, K, Ag, Na, Sr, Vn, and Zn & \\
Volatile Organics Analysis (VOAs) & 624 \\
Radionuclides & \\
\hline
\end{tabular}


Table 4.2 provides the analytical results for General Chemistry parameters for each sampling event and the associated groundwater quality criteria as listed in Washington Administrative Code (WAC) 173200. Nitrate exceeded the groundwater quality criteria in all sampling events (as shown in red), which is likely due to upgradient agricultural activities, and total dissolved solids exceeded the groundwater quality criteria during the September 2008 sampling event.

Table 4.3 provides the analytical results for metals for each sampling event and the associated groundwater quality criteria as listed in WAC 173-200. Iron exceeded the groundwater quality criteria in September 2008 and is shown in red.

Each of the well samples collected was also analyzed for volatile organics using the priority pollutants listed in 40 CFR 122, Appendix D, Table II. Table 4.4 provides the results for volatile organic analysis (VOA). Only those analytes that were detectable are reported in Table 4.4. In all other cases, VOA results were not detectable.

Samples were submitted to RPL to analyze for total gross alpha/beta and tritium analyses. Table 4.5 provides the results from the radiological analyses, compared with the groundwater quality criteria as listed in WAC 173-200 limits. Radiological results for all well sampling events indicate that radiological parameters are less then federal drinking water standards. 
Table 4.2. General Chemistry

\begin{tabular}{|c|c|c|c|c|c|}
\hline \multirow[t]{2}{*}{ Sample } & \multicolumn{3}{|c|}{ Results (mg/L) } & \multicolumn{2}{|r|}{ WAC 173-200 (mg/L) } \\
\hline & 9/10/2008 & $3 / 16 / 2009$ & 3/18/2009 & $6 / 2 / 2009$ & \\
\hline $\mathrm{pH}$ & $\begin{array}{c}7.18 \\
\text { (pH units) }\end{array}$ & $\begin{array}{c}7.72 \\
\text { (pH units) }\end{array}$ & $\begin{array}{c}7.54 \\
\text { (pH units) }\end{array}$ & $\begin{array}{c}7.10 \\
\text { (pH units) }\end{array}$ & 6.5-8.5 (pH units) \\
\hline Conductivity & $744(\mu S)$ & $735(\mu S)$ & $786(\mu S)$ & & \\
\hline Alkalinity & & & & 189 & \\
\hline Chloride & & & & 26.6 & 250 \\
\hline Fluoride & & & & 0.190 & 4 \\
\hline Nitrite & ND & ND & ND & ND & --- \\
\hline Nitrate & 20.1 & 20.8 & 23.5 & 21.8 & 10.0 \\
\hline Sulfate & NA & 76.2 & 71.3 & 76.6 & 250 \\
\hline Orthophosphate & 0.05 & 0.04 & 0.04 & 0.04 & -- \\
\hline $\begin{array}{l}\text { Total Dissolved } \\
\text { Solids }\end{array}$ & 505 & 474 & 471 & & 500 \\
\hline $\begin{array}{l}\text { Cation-Anion } \\
\text { Balance Calculation }\end{array}$ & $\begin{array}{c}\text { Cation Sum } \\
8.24 \text { (meq/L) }\end{array}$ & $\begin{array}{c}\text { Anion Sum } \\
7.63(\mathrm{meq} / \mathrm{L})\end{array}$ & \%Difference 4 & & \\
\hline
\end{tabular}

Table 4.3. Metals

\begin{tabular}{|c|c|c|c|c|c|}
\hline Sample & \multicolumn{3}{|c|}{ Results (mg/L) } & \multicolumn{2}{|r|}{ WAC 173-200 (mg/L) } \\
\hline & $9 / 10 / 2008$ & $3 / 16 / 2009$ & $3 / 18 / 2009$ & $6 / 2 / 2009$ & \\
\hline Barium & 0.088 & 0.084 & 0.0743 & & 1.0 \\
\hline Beryllium & $<0.0001^{\text {(a) }}$ & $0.0001^{(\mathrm{b})}$ & $<0.0001^{(\mathrm{a})}$ & & -- \\
\hline Cadmium & $<0.0002^{(\mathrm{a})}$ & $<0.0002^{(\mathrm{a})}$ & $<0.002^{(\mathrm{a})}$ & & 0.01 \\
\hline Calcium & 90.6 & 89.4 & 90.8 & 99 & --- \\
\hline Chromium & 0.0026 & $<0.0009^{(a)}$ & $<0.002^{(\mathrm{a})}$ & & 0.05 \\
\hline Cobalt & 0.0006 & 0.0005 & $<0.002^{(a)}$ & & --- \\
\hline Copper & 0.073 & 0.0053 & $<0.004^{(\mathrm{a})}$ & & 1.0 \\
\hline Iron & 0.535 & 0.0306 & 0.0304 & & 0.30 \\
\hline Magnesium & 19.9 & 19.8 & 20.2 & 21.4 & --- \\
\hline Manganese & 0.0163 & 0.0033 & 0.0009 & & 0.05 \\
\hline Nickel & 0.0015 & $<0.0005^{(a)}$ & $<0.002^{(\mathrm{a})}$ & & --- \\
\hline Potassium & 8.21 & 7.82 & 7.93 & 7.91 & --- \\
\hline Silver & $<0.0007^{(\mathrm{a})}$ & $<0.0007^{(a)}$ & $<0.007^{(a)}$ & & 0.05 \\
\hline Sodium & 30.3 & 29.8 & 30.8 & 30.8 & --- \\
\hline Strontium & 0.412 & 0.412 & 0.399 & & --- \\
\hline Vanadium & 0.0104 & 0.0087 & 0.007 & & --- \\
\hline Zinc & 0.0145 & 0.0285 & 0.0142 & & 5.0 \\
\hline
\end{tabular}

(a) Result was nondetectable and is reported as less than the method detection limit.

(b) Method blank for beryllium was contaminated at $0.0001 \mathrm{mg} / \mathrm{L}$, resulting in a significant high bias to the result. 
Table 4.4. Volatile Organic Analyses (VOAs)

\begin{tabular}{l|ccc|c}
\hline Sample & \multicolumn{3}{|c}{ Results $(\mu \mathrm{g} / \mathrm{L})$} & WAC $173-200(\mu \mathrm{g} / \mathrm{L})$ \\
\hline & $9 / 10 / 2008$ & $3 / 16 / 2009$ & $3 / 18 / 2009$ & \\
\hline Toluene & ND & 0.25 & ND & --- \\
Bromomethane & ND & ND & 0.43 & --- \\
\hline ND = Not Detected
\end{tabular}

Table 4.5. Total Alpha/Beta and Isotopic Analyses

\begin{tabular}{l|ccc|c}
\hline Sample & \multicolumn{3}{|c}{ Results (pCi/L) } & WAC 173-200 (pCi/L) \\
\hline & $9 / 10 / 2008$ & $3 / 16 / 2009$ & $3 / 18 / 2009$ & \\
\hline Alpha & 4.29 & 7.71 & $<6.0$ & 15 \\
Beta & 9.9 & 6.48 & 6.22 & 50 \\
Tritium & NA & 621 & 640 & 20000 \\
\hline \multicolumn{7}{l}{ NA=Not Available }
\end{tabular}




\subsection{Numerical Simulations}

\subsection{Model Setup}

Aerial photos and site maps were used to define the model boundaries in plan view. The model domain was selected so that 1 ) extraction and injection of groundwater could be simulated with minimal impact from the model boundaries and 2) local sites and features relevant to the GSHP were included, such as the DOE landfill, the 300 Area, the North Richland Well Field, and the Columbia River (Figure 5.1). Note that the eastern boundary of the domain represents the shoreline along the Columbia River.

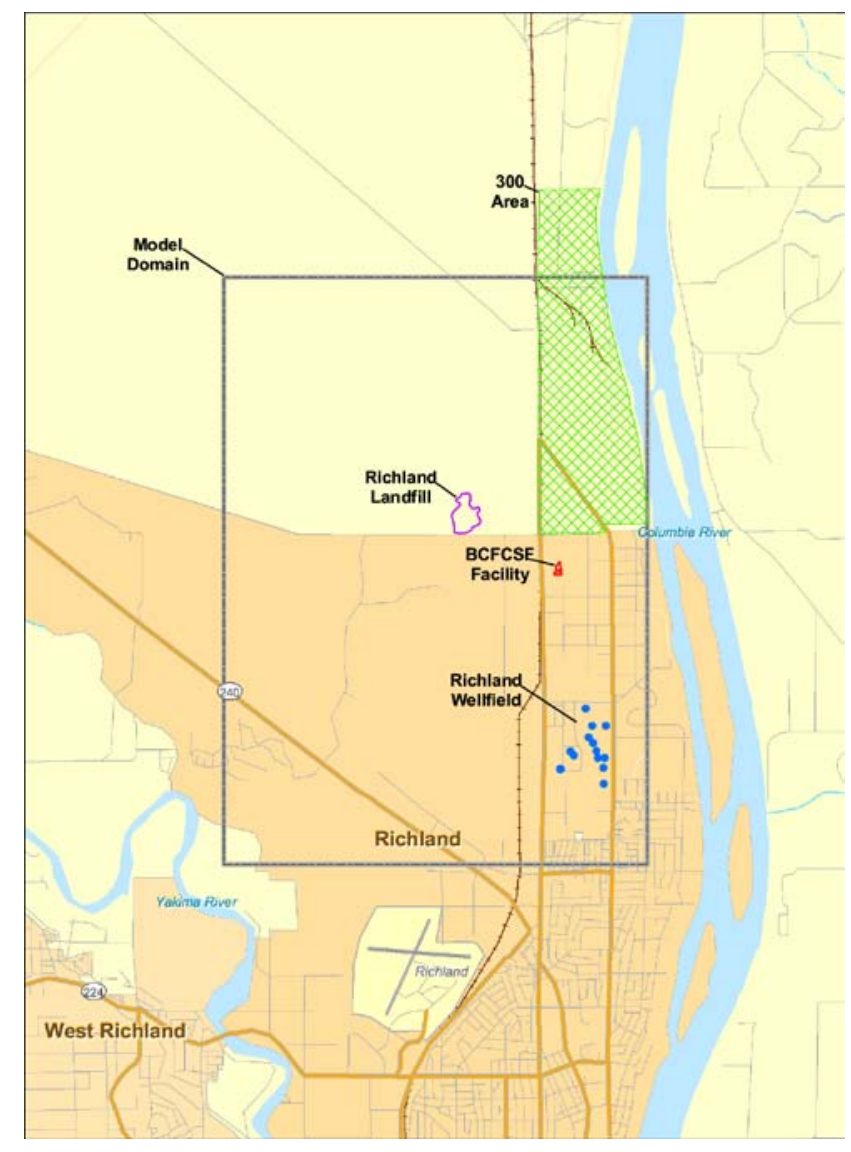

Figure 5.1. Features Included in the Model Domain

The Hanford and Ringold Formations represent the sediments in the saturated zone. The Hanford formation is the uppermost unit and is dominated by gravel and coarse-grained sand. Figure 5.2 is a map of contours of the elevation of the contact (based on field data) between the Ringold and the Hanford formations. Figure 5.3 is a contour map showing the saturated thickness of the two formations. At the $\mathrm{BSF} / \mathrm{CSF}$ site, the water table is predominantly in the Ringold Formation, but the saturated thickness of the Hanford formation increases with proximity to the river. The saturated thickness of the combined 
Hanford and Ringold Formations is between 45 and $50 \mathrm{~m}$ at the BSF/CSF site (Figure 5.3). Crosssectional views of the geology are shown in Figure 5.4.

The model grid used to conduct the flow simulations is $49 \times 58 \times 44$ nodes in the $\mathrm{x}-$, $\mathrm{y}$-, and $\mathrm{z}$ directions, respectively, for a total of 125,048 cells of which 28,926 are inactive. This coarse discretization was used to reduce potentially long simulation times. The domain was discretized with greater refinement in the vicinity of the wells (50 $\mathrm{m}$ in $\mathrm{x}$ - and $\mathrm{y}$-), and cell sizes grew progressively larger as they moved outward from the BSF/CSF property boundary. The largest grid cell in both $\mathrm{x}$ - and $\mathrm{y}$ directions is $156.25 \mathrm{~m}$. In the vertical direction, the grid was discretized in equally spaced 1.0-meter increments. The geology was assigned to the grid on a cell-by-cell basis. A plan view of the discretized domain is shown in Figure 5.5.

A well model was used in the flow simulations that allowed for an input specification of a well radius within the grid cell. Extraction wells were assumed to be screened across the entire Ringold Formation, whereas injection wells were screened in the upper Ringold and Hanford Formations (from 109-116 m elevation). In the heat transport simulations, water injection and extraction were simulated as volumetric water sources with well radii that spanned the entire width of the cell because the well model was not available in STOMP-WAE. While the total volume of water was the same with either method, in the absence of a well model, water movement for the specified source occurred over the entire grid cell. Cell sizes at the well locations were $50 \mathrm{~m}$ square. Hence, in the energy transport simulations, injected water immediately spread $50 \mathrm{~m}, 200$ times the width of a 0.25 -m well casing. This resulted in conservative (shorter) travel time estimates to the Columbia River, and subsequently higher temperature estimates than what may be observed in the field. 


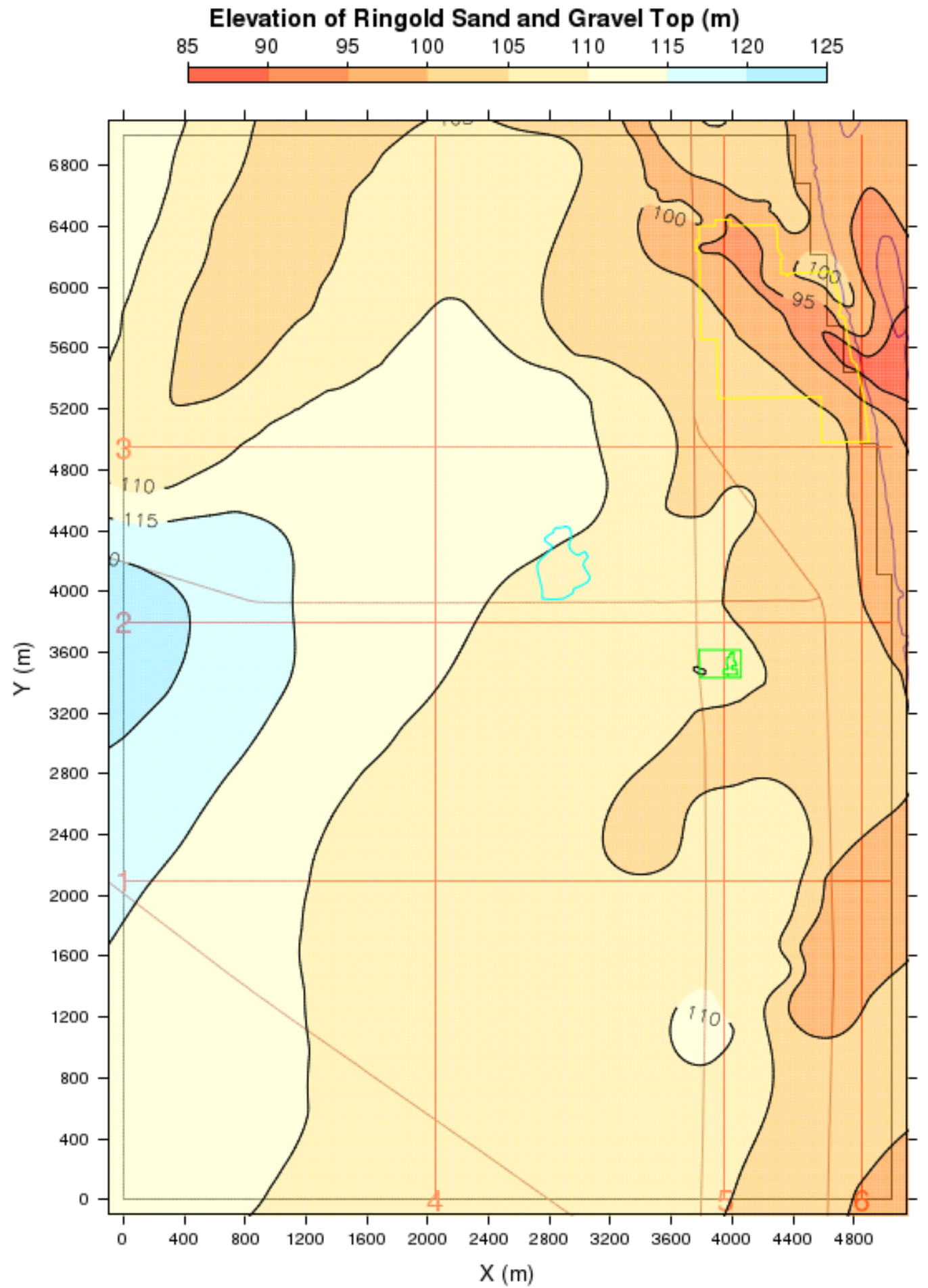

Figure 5.2. Contact Between the Hanford and Ringold Formations. The Horn Rapids DOE landfill is outlined in light blue, the 300-Area outline is yellow, the Richland well locations are marked in dark blue, and the BSF/CSF facility and property are shown in green. Transect lines correspond to cross-sections shown in Figure 5.4. 


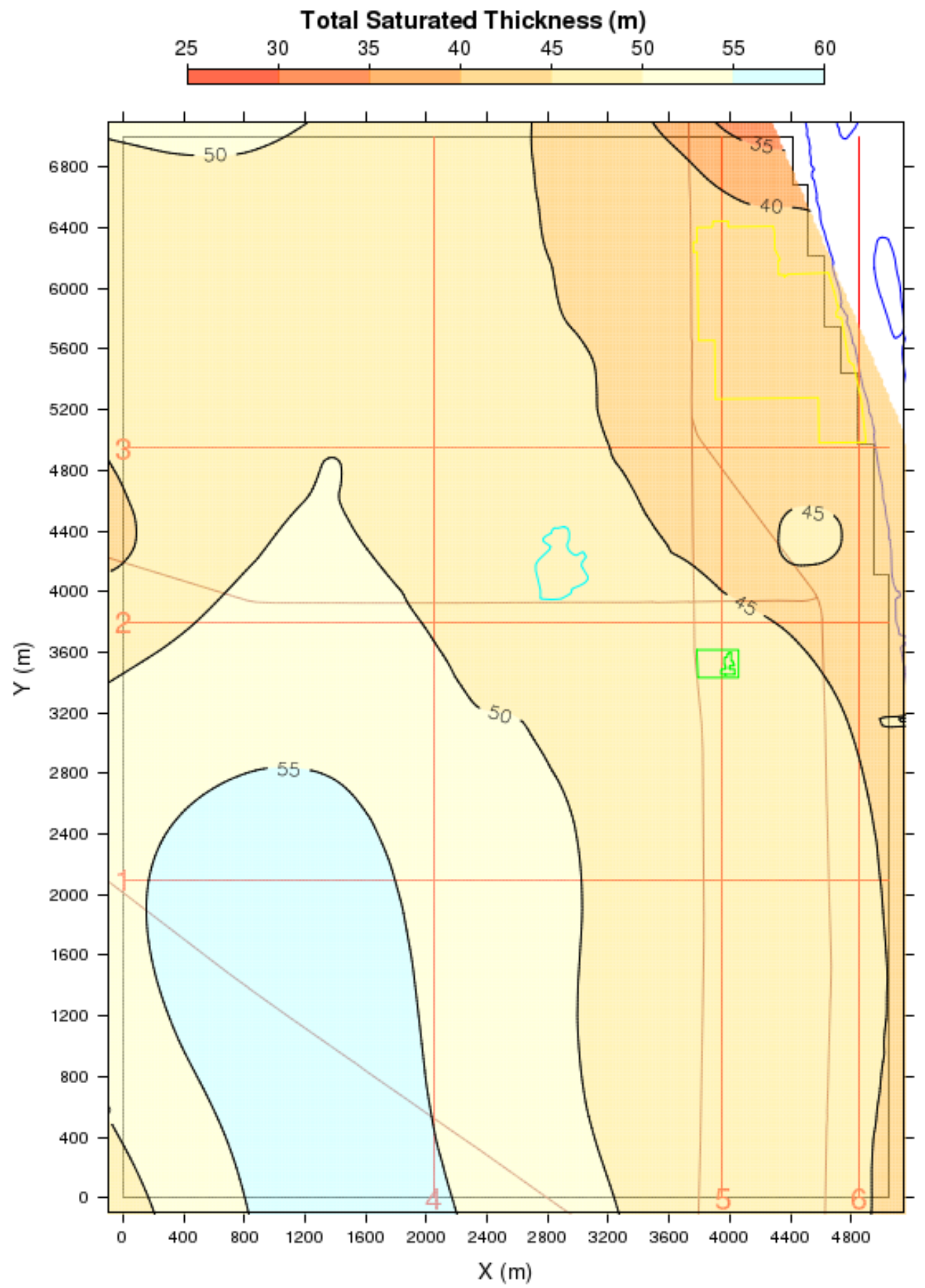

Figure 5.3. S Saturated Thickness of the Ringold and Hanford Formations. The Horn Rapids DOE landfill is outlined in light blue, the 300-Area outline is yellow, the Richland well locations are marked in dark blue, and the BSF/CSF facility and property are shown in green. Transect lines correspond to cross-sections shown in Figure 5.4. 


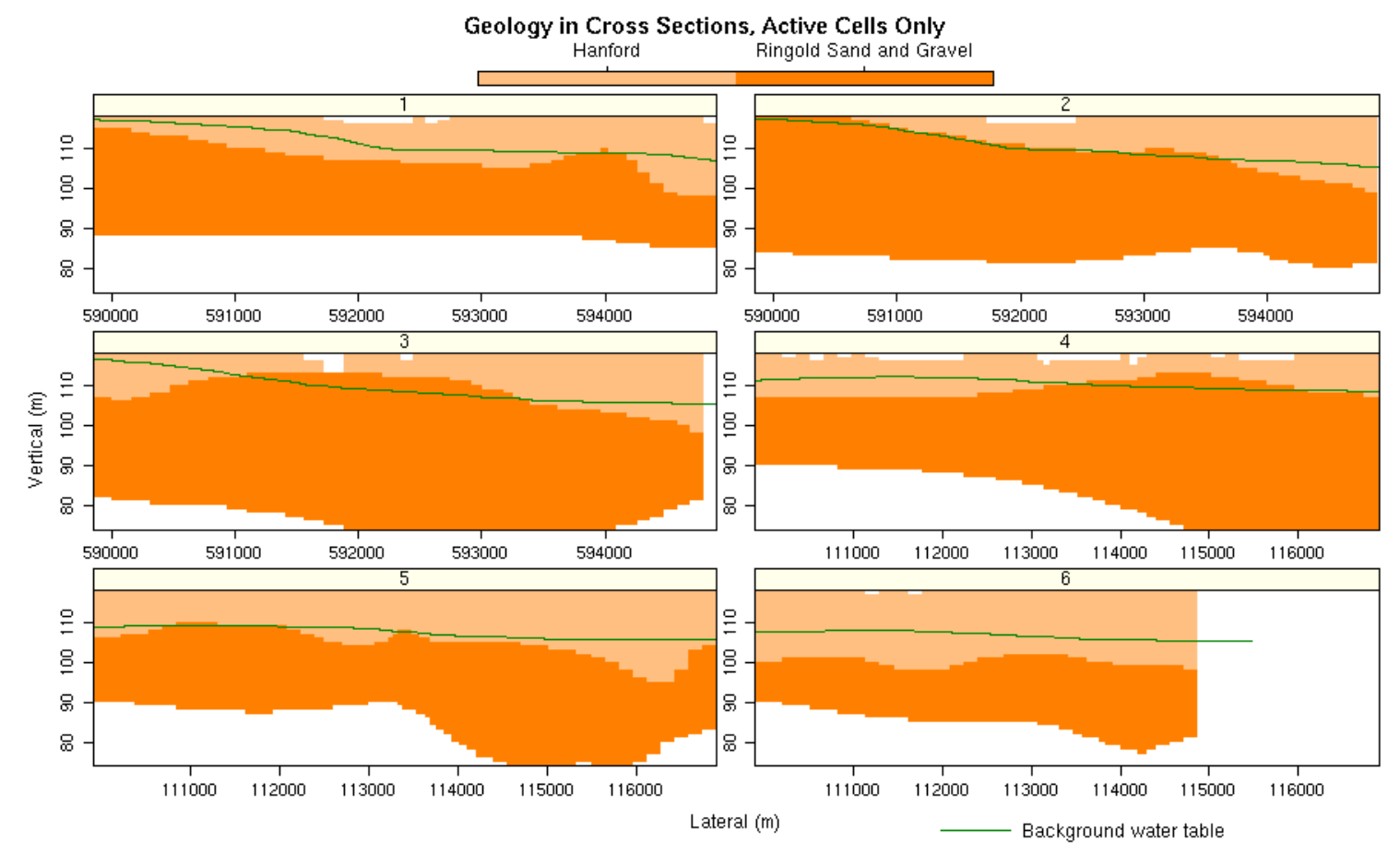

Figure 5.4. Geologic Cross-Sections Corresponding to the Numbered Transects in Figure 5.2 and Figure 5.3. 


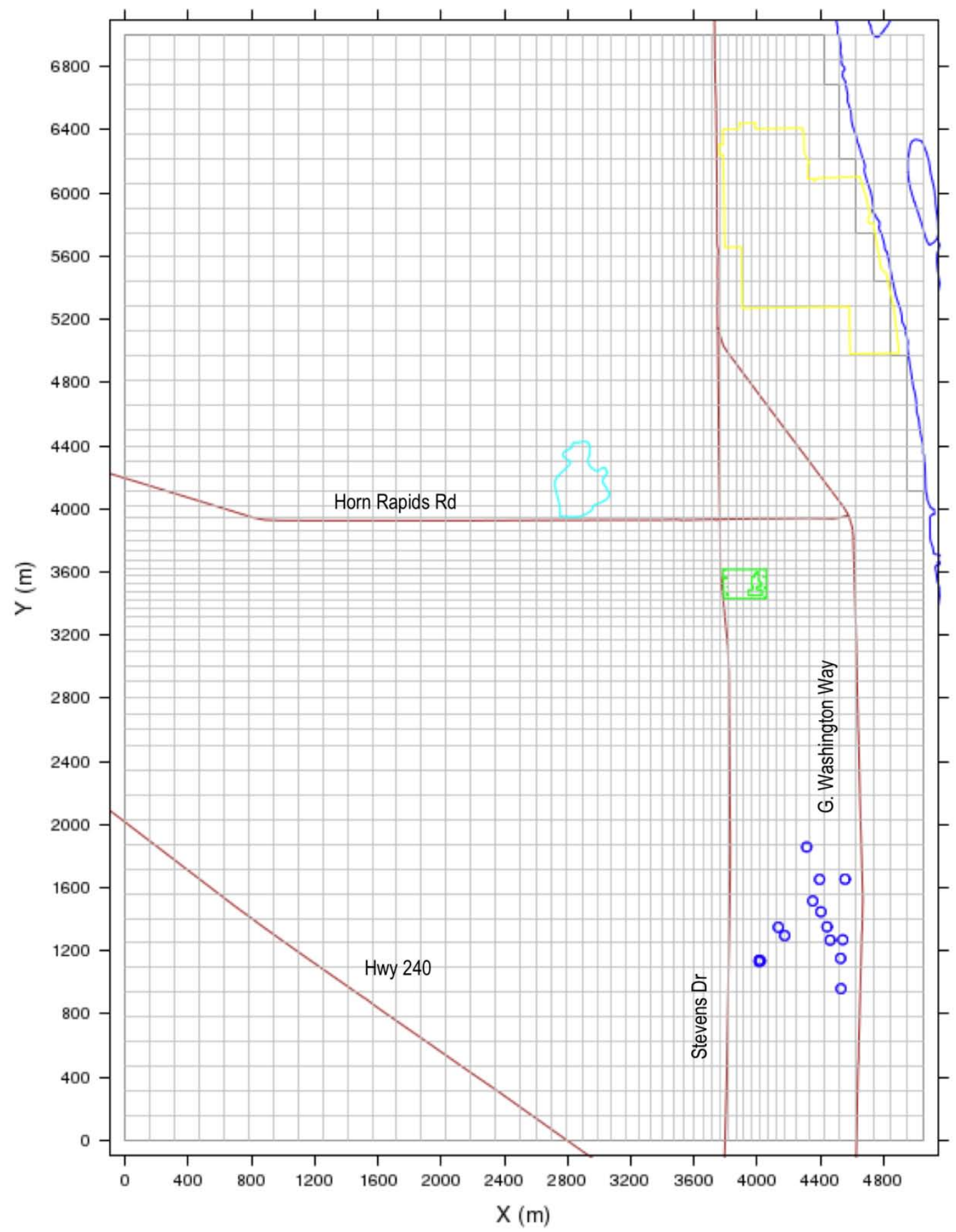

Figure 5.5. STOMP Model Grid $(49 \times 58 \times 44)$. The Horn Rapids DOE landfill is outlined in light blue, the 300-Area outline is yellow, the Richland well locations are marked in dark blue, and the BSF/CSF facility and property are shown in green. 
Parameters for flow and heat transport were required for input into STOMP. For flow, key parameters included the saturated hydraulic conductivity and the unsaturated hydraulic properties for both the Hanford and Ringold Formations. Saturated hydraulic conductivity estimates for the Ringold Formation (60 and $150 \mathrm{~m} / \mathrm{d}$ ) were based on the constant-rate pump test performed at Well 2. A vertical anisotropy ratio of 10:1 was assumed to represent the contrast between the horizontal and vertical hydraulic conductivities in both the Ringold and Hanford formations. For the Hanford formation, the saturated hydraulic conductivity was estimated at 6,560 ft/d (2,000 m/d) throughout the entire model domain, based on a literature review with input from subject matter experts (e.g., Liikala 1994, Williams et al. 2007, Meyer et al. 2007, Yabusaki et al. 2008).

For unsaturated zone parameters in the STOMP code, a Brooks-Corey function was used with a Burdine porosity distribution model for aqueous relative permeability. The air-entry pressure and lambda parameters for the Hanford formation are based on data from Rockhold et al. (1988, p. A.1), which represent the "L-soil" sediment used in lysimeters, located north of the 300 Area. The irreduciblesaturation parameter, Sr, was estimated based on data from well 699-S20-E10 (Williams et al. 2008).

Heat-transfer simulations required estimates of thermal conductivity and the specific heat for both the Ringold and Hanford Formations. Estimates of thermal conductivity and specific heat were based on Hanford Site values reported in the literature (Pruess 2000, Ward 2007). In this analysis, it was assumed that heat transfer was anisotropic because finer grained sediments underlay coarser grained sediments in the Ringold Formation. Thermal conductivity was fixed to a constant value, independent of temperature or saturation.

Because no range of thermal parameters were reported in Pruess 2000 and Ward 2007, and because initial simulations demonstrated that temperature predictions were not very sensitive to thermal parameter estimates for the Hanford and Ringold formations, a range of thermal parameters was not used. These input parameters, as well as selected hydraulic input parameters, are listed in Table 5.1.

Table 5.1. Hydraulic and Thermal Input Parameters

\begin{tabular}{|c|c|c|c|c|c|c|c|c|}
\hline Material & $\begin{array}{c}\text { Total \& } \\
\text { Diffusive } \\
\text { Porosity } \\
(\%)\end{array}$ & $\begin{array}{c}\text { Air-entry } \\
\text { Pressure } \\
\text { (cm) }\end{array}$ & Lambda & $\begin{array}{l}\text { Irreducible } \\
\text { Saturation }\end{array}$ & $\begin{array}{c}\text { Saturated } \\
\text { Hydraulic } \\
\text { Conductivity } \\
(\mathrm{m} / \mathrm{d})\end{array}$ & $\begin{array}{c}\text { Horizontal } \\
\text { Thermal } \\
\text { Conductivity } \\
\left(\mathrm{W} / \mathrm{m}^{\circ} \mathrm{C}\right)\end{array}$ & $\begin{array}{c}\text { Vertical } \\
\text { Thermal } \\
\text { Conductivity } \\
\left(\mathrm{W} / \mathrm{m}^{\circ} \mathrm{C}\right)\end{array}$ & $\begin{array}{c}\text { Specific } \\
\text { Heat } \\
\left(\mathrm{J} / \mathrm{kg}^{\circ} \mathrm{C}\right)\end{array}$ \\
\hline Hanford & 20 & 14.04 & 1.97 & 0.16 & 2000 & 1.10 & 1.70 & 730 \\
\hline Ringold & 25 & 71.31 & 0.519 & 0.13 & 60 and 150 & 1.69 & 2.25 & 800 \\
\hline
\end{tabular}

\subsection{Initial and Boundary Conditions}

The initial water table configuration was determined using the water table representing the Spring 2006 condition for the Hanford Site. For both the flow and heat-transfer simulations, the west, north, and south sides of the rectangular domain were assigned specified-flux boundary conditions based on the Spring 2006 water table condition. The eastern boundary of the domain, which represents the river, was assigned a fixed pressure, time-invariant, hydrostatic boundary condition based on the average river-stage data. The top boundary of the model was set to a defined flux of $60 \mathrm{~mm} / \mathrm{yr}$, a representative annual 
recharge rate from rainfall and snowmelt for the southern Hanford Site (Gee et al. 2005). The bottom boundary of the model was a no-flow boundary.

For the heat-transfer simulations, boundary conditions for gas were set as zero flux on all sides of the rectangular domain, except for the top. The gas pressure was set as a constant pressure boundary at atmospheric pressure. For temperature, a zero flux boundary was set at the bottom, and constant temperature boundaries were assigned at the top and east (river) boundaries. Outflow boundaries for temperature were assigned at all other boundaries, allowing convective heat to be transported across those boundaries. The constant temperature boundaries and initial temperature distribution were assigned a value of $16.4^{\circ} \mathrm{C}$.

\subsection{Flow Simulations}

This section of the report discusses the methodology for conducting flow simulations of groundwater flow with and without the GSHP (Section 5.3.1), followed by a discussion of the results of the model simulations (Section 5.3.2).

\subsubsection{Methodology}

The purpose of the flow simulations was to aid in assessing impacts of the well field with respect to nearby water right holders and existing contaminant plumes. As requested by Ecology, we have used the radius of influence for both purposes; that is, if a small (cm-level) drawdown is predicted by an analytical or numerical solution, then the radius of influence extends to that distance, and any subsurface contamination within that radius is negatively impacted by the well field. This definition of the radius of influence is based on the Thiem equation, which is a mathematical expression that identifies the farthest distance from a well at which there is a change in the water table elevation due to pumping from the well. This is a simple scientific concept, but not a metric for evaluating the questions concerning potential impacts of GSHP operations on other water users and on existing contaminant plumes. Given the nature of the questions at hand, we use the "radius of influence" concept as a means of identifying the distance from the GSHP wells at which groundwater elevations and flow directions are significantly altered by GSHP system operations. This approach is used to apply the "radius of influence" concept to the specific issues being evaluated for the purposes of permitting decisions.

Hence, in this section, results of steady-state flow fields are presented with and without the well field to analyze local impacts to the flow system. Difference plots are presented that show the resulting changes in hydraulic head when wells are pumping at steady flow rates. Also shown in these plots are particle tracks released from the upgradient boundary, which help identify any potential changes in flow paths. A capture zone analysis is used to identify the location of the water source drawn into the well system. All of these results are used in conjunction with professional judgment to identify a radius of influence.

Four simulation cases were executed in this analysis. Cases 1 and 2 examined impacts using a total pumping rate of 1400 gpm whereas Cases 3 and 4 examined impacts at 1900 gpm. The latter represented a maximum rate that may be reached for a few hours per day during the summer months when peak cooling loads are high. The lower rate is the maximum steady-state pumping rate expected from the well 
field (without causing wells to go dry). Both rates exceed the monthly average pumping rates expected for the well field (627 to 1091 gpm).

The Ringold hydraulic conductivity was represented as $60 \mathrm{~m} / \mathrm{d}(200 \mathrm{ft} / \mathrm{d})$ in Cases 1 and 3, and as $150 \mathrm{~m} / \mathrm{d}(500 \mathrm{ft} / \mathrm{d})$ in Cases 2 and 4 . Simulations represented the wells with screens that extended across the Ringold Formation, $>3$ m below the Hanford-Ringold contact to the contact with the Ringold Mud unit at the base of the model. Well screen lengths varied from 16 to $18 \mathrm{~m}$, depending on the Ringold saturated thickness.

\subsubsection{Results}

Inverse calibration of the BSF/CSF model was not performed because a range of hydraulic conductivity estimates were assumed for the Ringold Formation based on pumping tests at the BSF/CSF site. This is a conservative approach because the hydraulic conductivity for the Ringold at the BSF/CSF site is higher than what has been measured at the Hanford Site (see Figures D.1 and D.2), and the same hydraulic conductivity has been assigned to all like units in the model. This approach likely yields predictions of maximum flow velocities reaching the shoreline. Given that heterogeneities hydraulic conductivity distributions are unknown, a homogeneous approach that yields conservative flow predictions was used.

Two steady-state water-table configurations were simulated using the bounding estimates of the Ringold saturated hydraulic conductivity: $60 \mathrm{~m} / \mathrm{d}$ and $150 \mathrm{~m} / \mathrm{d}$. Particles released upgradient (west boundary) show the steady flow paths before pumping (Figure 5.6). Few data were available for comparing the simulated potentiometric surface with the observed Spring 2006 water-level data. Table 5.2 lists wells within the model domain, the mean water level for all available years, and the water level for the Spring of 2006. Table 5.2 shows the mean values of (1) the simulation error and (2) the absolute value of the simulation error. The mean of the simulation error ranges from 0.54 to 0.61 meters (1.8 to 2.0 feet), and the mean of the absolute values of the simulation errors ranges from 0.35 to 0.47 meters (1.1 to 1.5 feet).

Model fit can also be evaluated by comparing the horizontal hydraulic gradient and the groundwater flow path lengths from the BSF/CSF site to the shoreline for the two steady-state water-table configurations (using Ringold horizontal hydraulic conductivities of $60 \mathrm{~m} / \mathrm{d}$ and $150 \mathrm{~m} / \mathrm{d}$ ). Flow paths for both cases were obtained using particle tracking from the center of the BSF/CSF site. For the $60 \mathrm{~m} / \mathrm{d}$ case, the flow path length was $1130.5 \mathrm{~m}$ (gradient $=1.7 \times 10^{-3} \mathrm{~m} / \mathrm{m}$ ), whereas for the $150 \mathrm{~m} / \mathrm{d}$ estimate, the flow path length was $1174.7 \mathrm{~m}$ (gradient $=1.8 \times 10^{-3} \mathrm{~m} / \mathrm{m}$ ). These flow path lengths are shorter than the estimated path length of $1216 \mathrm{~m}$ from Figure 2.7 (gradient $=2.0 \times 10^{-3} \mathrm{~m} / \mathrm{m}$ ). Therefore, the model is conservative in terms of simulating a shorter flow path for thermal transport than is estimated to be present at the site. 


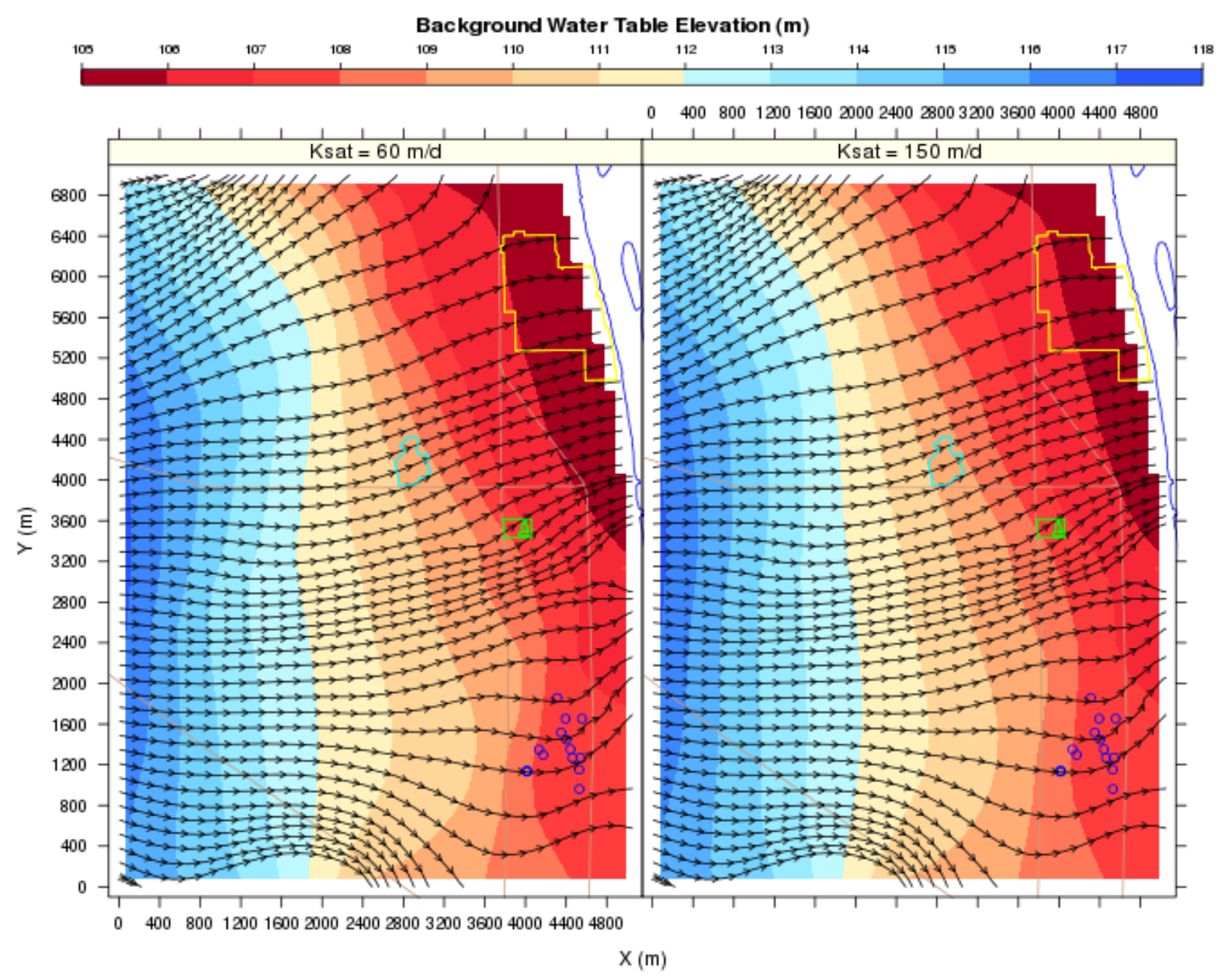

Figure 5.6. Steady-State Water-Table Configuration With Particle Tracks for Particles Released at the Upgradient Western Boundary. Plots shown are for the Ringold hydraulic conductivity estimated at a) $60 \mathrm{~m} / \mathrm{d}$ and b) $150 \mathrm{~m} / \mathrm{d}$.

Figure 3.2 shows that for the wells just north of the BSF/CSF site, the horizontal hydraulic gradient obtained from site water level measurements ranges from $1.0 \times 10^{-3} \mathrm{~m} / \mathrm{m}$ to $2.0 \times 10^{-3} \mathrm{~m} / \mathrm{m}$. Consequently, the simulated gradient of $1.7 \times 10^{-3} \mathrm{~m} / \mathrm{m}$ to $1.8 \times 10^{-3} \mathrm{~m} / \mathrm{m}$ falls within the natural variability of the groundwater flow system. The flow directions shown in Figure 3.2 range between 35 and 62 degrees east of north. Flow directions obtained from both simulated cases of hydraulic conductivity (56 degrees east of north) and from Figure 2.7 (43 degrees east of north), are also within the natural variability of flow directions at the site.

The two conceptual models demonstrate similar flow behavior because they are both highly constrained by the boundary and initial conditions. The largest error found in wells west of the site may lie in the geologic conceptual model west of the DOE Landfill. As shown in Figure 2.7, wells are sparsely located in this region and the geology is largely unknown. However, flow paths, gradients and directions demonstrate that the conceptual models adequately represent the water table conditions shown in Figure 2.7 and Figure 3.2 . 
Table 5.2. Water-Level Comparison of Simulated and Observed Heads

\begin{tabular}{|c|c|c|c|c|c|c|c|c|}
\hline \multirow[b]{2}{*}{ Well } & \multirow[b]{2}{*}{$\begin{array}{c}\text { \# Obs } \\
\text { in } \\
2006\end{array}$} & \multirow{2}{*}{$\begin{array}{c}2006 \\
\text { Observed } \\
(3 / 20 / 06- \\
5 / 26 / 06) \\
\text { (m) }\end{array}$} & \multicolumn{3}{|c|}{ Ringold $\mathrm{K}_{\text {sat }} 60 \mathrm{~m} / \mathrm{d}$} & \multicolumn{3}{|c|}{ Ringold $\mathrm{K}_{\text {sat }} 150 \mathrm{~m} / \mathrm{d}$} \\
\hline & & & $\begin{array}{l}\text { Simulated } \\
(\mathrm{m})\end{array}$ & $\begin{array}{l}\text { Absolute } \\
\text { Error } \\
\text { (m) }\end{array}$ & $\begin{array}{c}\text { Mean } \\
\text { Error } \\
\text { (m) }\end{array}$ & $\begin{array}{l}\text { Simulated } \\
\text { (m) }\end{array}$ & $\begin{array}{l}\text { Absolute } \\
\text { Error } \\
\text { (m) }\end{array}$ & $\begin{array}{c}\text { Mean } \\
\text { Error } \\
(\mathrm{m})\end{array}$ \\
\hline 699-S34-E15 & 2 & 107.11 & 106.63 & 0.48 & -0.48 & 106.64 & 0.47 & -0.47 \\
\hline 699-S34-E10 & 2 & 109.28 & 109.85 & 0.57 & 0.57 & 109.87 & 0.60 & 0.60 \\
\hline 699-S32-E13A & 2 & 106.79 & 106.40 & 0.39 & -0.39 & 106.66 & 0.13 & -0.13 \\
\hline 699-S32-E11 & 1 & 108.20 & 108.94 & 0.74 & 0.74 & 108.89 & 0.69 & 0.69 \\
\hline 699-S31-E10D & 1 & 107.98 & 108.96 & 0.98 & 0.98 & 108.99 & 1.00 & 1.00 \\
\hline 699-S31-E10B & 1 & 108.04 & 108.83 & 0.79 & 0.79 & 108.90 & 0.86 & 0.86 \\
\hline 699-S30-E15A & 1 & 105.44 & 105.65 & 0.22 & 0.22 & 105.77 & 0.33 & 0.33 \\
\hline 699-S30-E11A & 1 & 106.60 & 106.95 & 0.36 & 0.36 & 107.40 & 0.80 & 0.80 \\
\hline 699-S32-E13B & 1 & 106.79 & 106.61 & 0.18 & -0.18 & 106.97 & 0.18 & 0.18 \\
\hline 699-S31-E11 & 1 & 106.88 & 107.29 & 0.41 & 0.41 & 107.54 & 0.66 & 0.66 \\
\hline 699-S31-E10A & 1 & 107.83 & 108.70 & 0.87 & 0.87 & 108.80 & 0.97 & 0.97 \\
\hline \multicolumn{3}{|c|}{ Arithmetic Mean (m) } & & 0.54 & 0.35 & & 0.61 & 0.47 \\
\hline
\end{tabular}




\subsubsection{Drawdown/Mounding}

The difference in hydraulic head between the steady-state flow scenarios and scenarios in which the $\mathrm{BSF} / \mathrm{CSF}$ wells are pumping at constant rates is shown in Figure 5.7. Colored contour levels are shown as small as $1 \mathrm{~cm}$, which show that small-scale drawdown is predicted to the northern, southern, and western edges of the domain. More than $3 \mathrm{~m}$ of drawdown is predicted near the extraction wells, a magnitude similar to the drawdown observed in the field during pumping tests. Injection wells cause mounding in the water table only in the immediate vicinity of the well field. At the injection wells, the water table increases $\sim 1.3 \mathrm{~m}$, whereas a 1-cm increase is predicted at a maximum distance of $\sim 500 \mathrm{~m}$ from the injection wells.

Drawdown cones are steeper for Cases 1 and 3 (left column), which assume a lower hydraulic conductivity for the Ringold Formation (60 m/d vs. $150 \mathrm{~m} / \mathrm{d}$ ). Steady-state pumping at 1900 gpm causes cm-level drawdown to extend further east and west (second row), but water table differences between the two steady-state pumping scenarios are not significant. Drawdown predicted at such a small scale is subject to conceptual model and interpolation error, given that the conceptual model is discretized at a 1-m scale. 


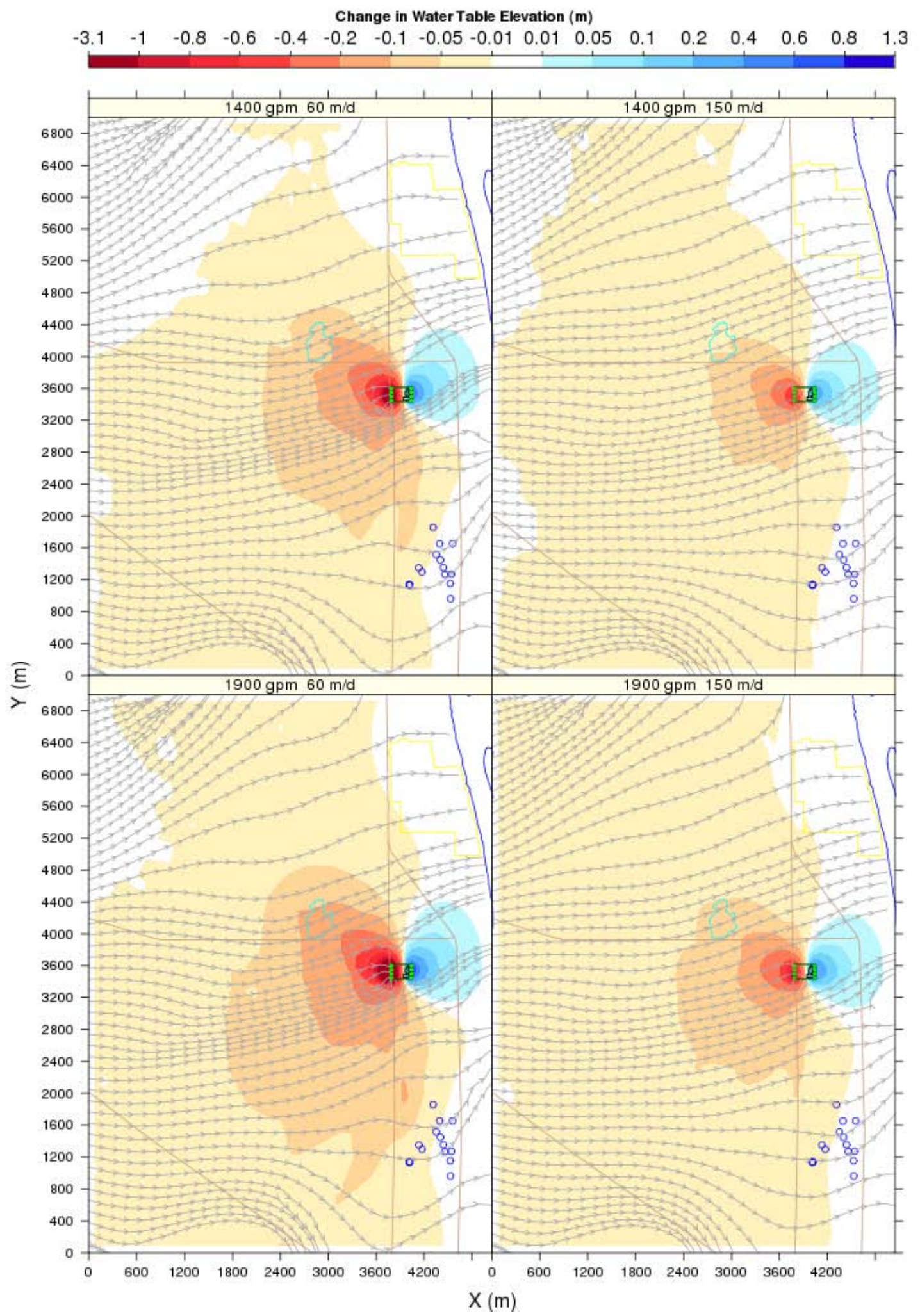

Figure 5.7. Difference Plots and Particle Tracks for Steady-State Pumping Rates of 1400 gpm (Cases 1 and 2) and 1900 gpm (Cases 3 and 4). Cases 1 and 3 assumed the saturated hydraulic conductivity of the Ringold Formation was $60 \mathrm{~m} / \mathrm{d}$; whereas Cases 2 and 4 assumed $150 \mathrm{~m} / \mathrm{d}$. 


\subsubsection{Flow Paths}

Particle tracks shown in Figure 5.7 demonstrate that the majority of particles released on the upgradient, western boundary are not captured by the well system. Groundwater at the DOE Horn Rapids Landfill still maintains a northeasterly flow direction, which indicates that contaminant plumes are not captured by the well system. The predicted drawdown extends much further than the area where local groundwater flow directions are significantly altered, which is defined by changes in the general flow direction. This occurs because the gradient toward the eastern boundary of the domain is steeper than the gradient to the well system.

Particle tracks with pumping (red pathlines) and without pumping (black pathlines) are plotted for all four simulation cases in Figure 5.8. Due to small scale changes in the water table, differences in flow paths exist throughout the entire domain. Although it simplifies the analysis to define a strict metric that any change constitutes negligible drawdown, it is not realistic for defining a potential negative impact to nearby contaminant plumes. Hence, a semi-quantitative metric is proposed that extends the radius of influence to where significant crossing of red and black pathlines does not occur. Since water right infringement is not an issue downgradient of the injection wells, the radius was not extended in this direction. Impact to the south is minimal relative to the other coordinate directions. Figure 5.8 shows that arrows have been drawn to the north and west from the north-south centerline of the extraction wells. To the north, the radius was estimated to extend $360 \mathrm{~m}$, whereas to the west, it was estimated to extend $540 \mathrm{~m}$ for all four simulation cases. For this metric, professional judgment has been used to define the radius of influence and it is recognized that other professionals may draw the radius to a different extent. 


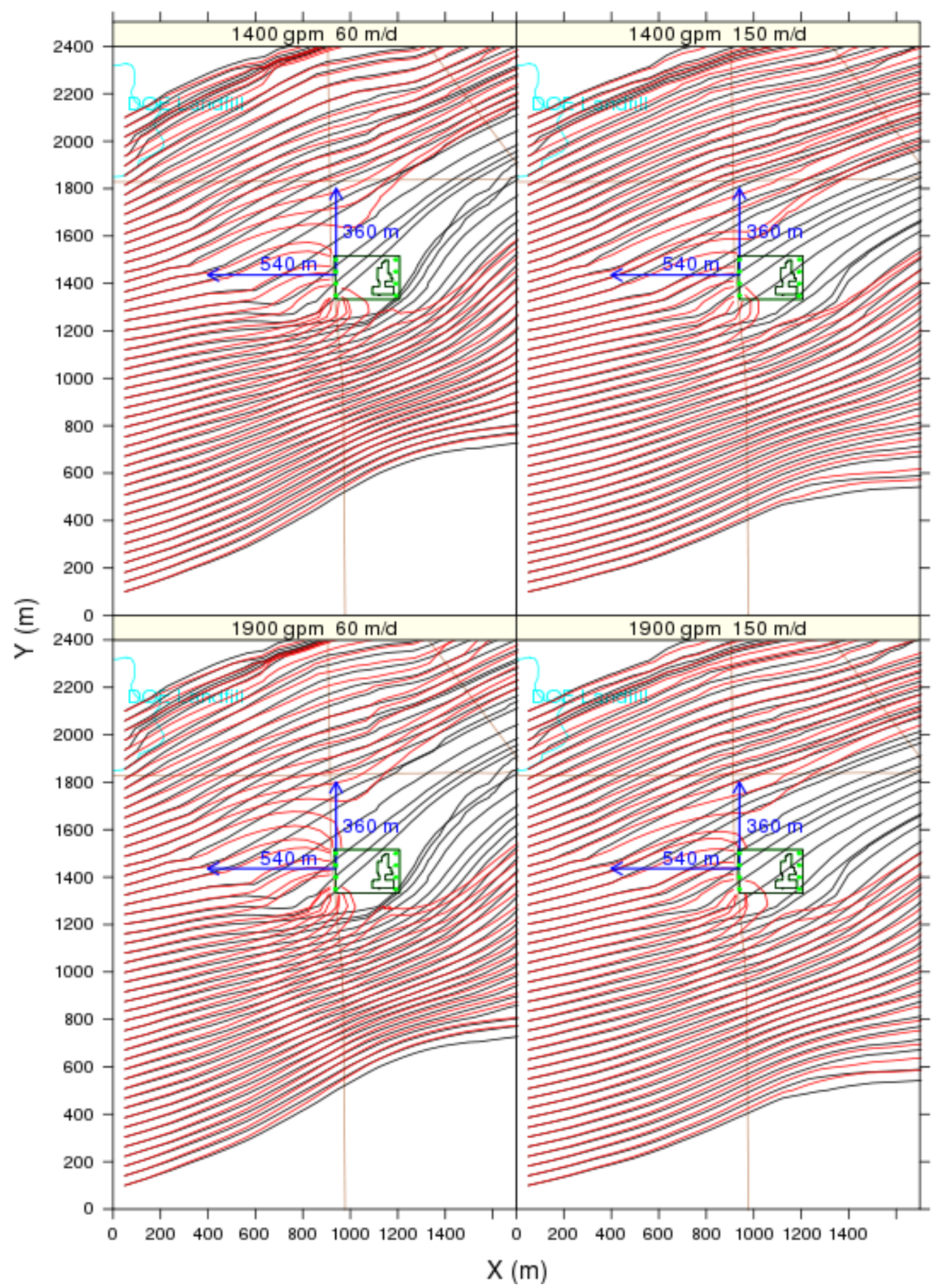

Figure 5.8. Flow Paths for the Groundwater Flow System without Pumping (Black) and with SteadyState Pumping Rates (Red) of 1400 gpm (Cases 1 and 2) and 1900 gpm (Cases 3 and 4). Cases 1 and 3 assumed the saturated hydraulic conductivity of the Ringold Formation was $60 \mathrm{~m} / \mathrm{d}$; whereas Cases 2 and 4 assumed $150 \mathrm{~m} / \mathrm{d}$. 


\subsubsection{GSHP Capture Zones}

A capture zone analysis was performed to identify the potential for the well system to draw in contaminant plumes. This approach provides a quantitative assessment of potential negative impacts to nearby contaminant plumes, especially with respect to the TCE plume whose outer edge lies $\sim 800 \mathrm{~m}$ to the northwest of the BSF/CSF site.

Capture zones for the GSHP well system were delineated by systematically releasing particles to the north (and south) of the extraction wells at increasing distances. The furthest particle captured identified the outer limit of the capture zone. Figure 5.9 shows the capture zones (400 to $600 \mathrm{~m}$ ) for all four cases in width transverse to the regional groundwater flow direction. As expected, higher hydraulic conductivities resulted in smaller capture zones whereas higher pumping rates resulted in larger capture zones. In general, the variability in hydraulic conductivities and pumping rates is small, which translates into a relatively small variability in the source zone for the groundwater drawn into the well system.

\subsubsection{Radius of Influence}

The radius of influence is identified here by jointly interpreting the drawdown plots, the particle tracks, and the delineated capture zones. The analysis demonstrates that the area over which drawdown will be $1 \mathrm{~cm}$ or less is extensive, extending a few $\mathrm{km}$ from the well system. However, flow paths are not significantly altered at distances greater than $600 \mathrm{~m}$ from the well system. This is demonstrated in the particle tracks shown in Figure 5.7, Figure 5.8, and the capture zone analysis in Figure 5.9. This distance corresponds to a maximum drawdown of $\sim 0.6 \mathrm{~m}$ for a continuous pumping rate of $1900 \mathrm{gpm}$. Since the drawdown analysis is subject to interpolation error, and flow paths are unaltered at distances where the drawdown prediction is small, the radius of influence can be established quantitatively using the capture zone prediction of $600 \mathrm{~m}$. This width coincides with the particle tracking analysis that estimated the radius of influence at $\sim 540 \mathrm{~m}$. This is a conservative estimate given that pumping rates will vary and will be less than the maximum 1900 gpm for most of the year. The maximum rate (1900 gpm) is expected to be reached for only a few hours a day during summer time peaks.

The outer edge of the TCE contaminant plume near the DOE Horn Rapids Landfill is located at a distance of $\sim 0.8 \mathrm{~km}$ north and west of the BSF/CSF site. The City of Richland well field is at a distance of $\sim 1.2 \mathrm{~km}$ from the site to the south and east. Both locations are outside of the $600 \mathrm{~m}$ radius of influence determined in this analysis. Hence, the well field will not draw contaminants from either the landfill or the 300 Area, and it is not expected to alter the current distribution of contaminants in those locations. 


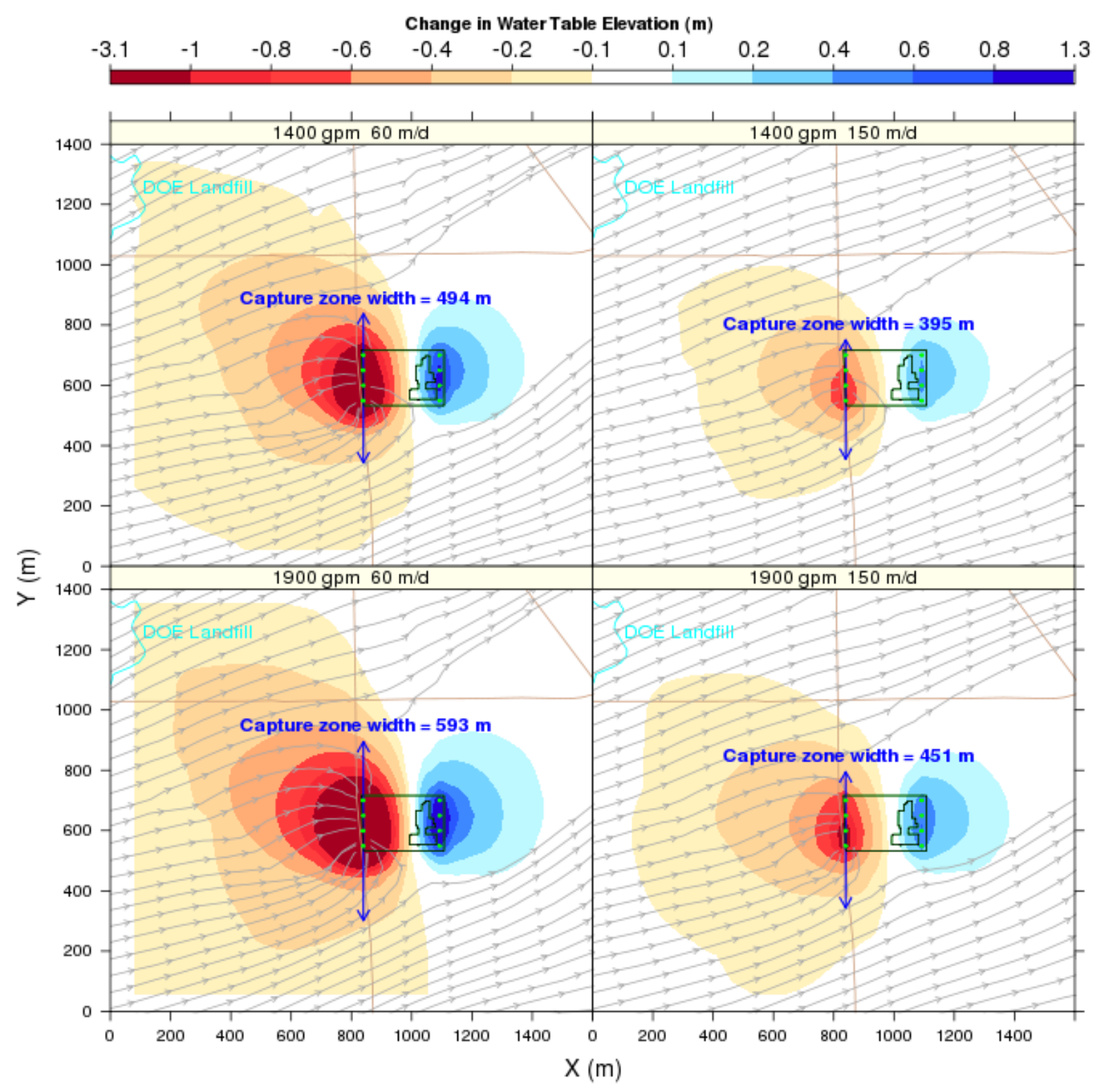

Figure 5.9. Capture Zones for Steady-State Pumping Rates of 1400 gpm (Cases 1 and 2) and 1900 gpm (Cases 3 and 4). Cases 1 and 2 assumed the saturated hydraulic conductivity of the Ringold Formation was 60 m/d; whereas Cases 2 and 4 assumed 150 m/d. 


\subsection{Thermal Transport Simulations}

This section of the report discusses the methodology for conducting simulations of thermal transport of heat in groundwater under GSHP system operations (Section 5.4.1), followed by a discussion of the results of the model simulations (Section 5.4.2).

\subsubsection{Methodology}

Thermal transport behavior was investigated using numerical simulations of flow and heat transport under a continuous flow regime. As previously discussed in Section 3.4, this was considered to be a conservative simulation approach since less mixing occurs with ambient groundwater for a steady-state flow model that does not account for daily or seasonal changes in river stage. In addition, no mixing calculations were performed in the hyporheic zone. Hence, temperatures reported at the eastern boundary of the model are not to be interpreted as an absolute temperature predicted at the Columbia River, but a conservative prediction of temperature for a small flux of groundwater approaching the Columbia River shoreline from the west.

Only the long-term operational scenario was evaluated. Once the facility is fully equipped in 5 years, continuous cooling of the building will be required. At that time, water injected to the subsurface will likely always be warmer than ambient.

Similar to the hydrologic investigation, thermal transport was investigated using the upper and lower estimates of hydraulic conductivity for the Ringold Formation. However, unlike the flow analysis, variable pumping rates were used to more accurately represent thermal transport conditions. Although variable pumping rates simulate some transience in the water table configuration, boundary conditions are still time invariant and the regional flow system is essentially steady-state.

Monthly data on pumping rates and injection temperatures were obtained using the DOE-2 building simulation program (see Section 2.1). Average (sub-case a) and peak (sub-case b) operational conditions were output from the simulation program and used to formulate the operational scenarios described in Section 3.4. The simulation that incorporated peak operating conditions assumed that a peak period was 12-hours, and that two consecutive peak periods occurred. This conservatively concentrated heat and pumping rates into a single month-long peak in July. The sub-cases were executed using the two hydraulic conductivity estimates for the Ringold Formation, $60 \mathrm{~m} / \mathrm{d}$ (Cases 1a-1b), and $150 \mathrm{~m} / \mathrm{d}$ (Cases 2a-2b), and were simulated for a period of 20 years. Pumping rates varied from 418 to 1900 gpm, and injection temperatures varied \pm 2.5 to $3.5^{\circ} \mathrm{C}$ from ambient (see Table 2.1 and Table 2.2).

\subsubsection{Results}

The primary objective of the thermal transport analysis is to identify the potential for elevated groundwater temperatures to impact the Columbia River. To this end, spatial distributions of temperatures were captured at quarter-year increments to determine the physical characteristics of thermal plumes. Vertical distributions of temperatures were examined using plan view maps of average and maximum temperatures obtained from the vertical profile. 
In groundwater, heat is transported by both conduction in the solid phase and by advection with moving water. When groundwater flow velocities are sufficiently high, most of the subsurface heat transport occurs by advection. Hence, higher flow velocities (i.e., higher hydraulic conductivity estimates) translate into higher heat transfer rates. To simplify the discussion of the thermal transport analysis, spatial distributions of temperature for the more conservative, upper estimate of hydraulic conductivity are presented for the peak scenarios. Simulation results for all cases are presented in Appendices E-H.

To examine groundwater temperatures at the eastern boundary of the model, temperatures were tracked with time for all nodes along the river shoreline that were within the trajectory of the thermal plume. Only the maximum temperatures were plotted for select nodes to identify the range in thermal behavior. Due to different hydraulic conductivities and operational scenarios, the locations of the maximum temperatures varied. The time-series plots presented in this section are not necessarily for the same locations in the domain, but represent the maximum temperatures along the shoreline impacted by the BSF/CSF well field. 


\subsubsection{Simulated Temperature Distribution Under the Continuous Heat Rejection Scenario (Including Peak-Day Injection Periods)}

The mean temperature distribution with depth for Case 2b (Peak Scenario, $150 \mathrm{~m} / \mathrm{d}$ ) is shown in Figure 5.10 for the time period of 18 to 20 years. The maximum temperature distribution with depth for the same time period is shown in Figure 5.11. Both figures depict a thermal plume that extends $\sim 1000 \mathrm{~m}$ along the shoreline. Temperature distributions between the mean and maximum temperature plots are similar along the shoreline, but show more significant differences in the vicinity of the well field. For example, Figure 5.11 shows that the maximum temperature is $\sim 19.5^{\circ} \mathrm{C}$ at 18.75 and 19.75 years within $\sim 100 \mathrm{~m}$ of the well field due to peak injection temperatures of $19.9^{\circ} \mathrm{C}$ that occurred in July. This feature is less notable in the mean temperature distribution because heat has not yet been transported with depth. Along the shoreline, the mean and maximum temperature distributions are similar similar ( 17.0 to $17.3^{\circ} \mathrm{C}$ ) ) because the vertical distribution of temperature is more uniform.

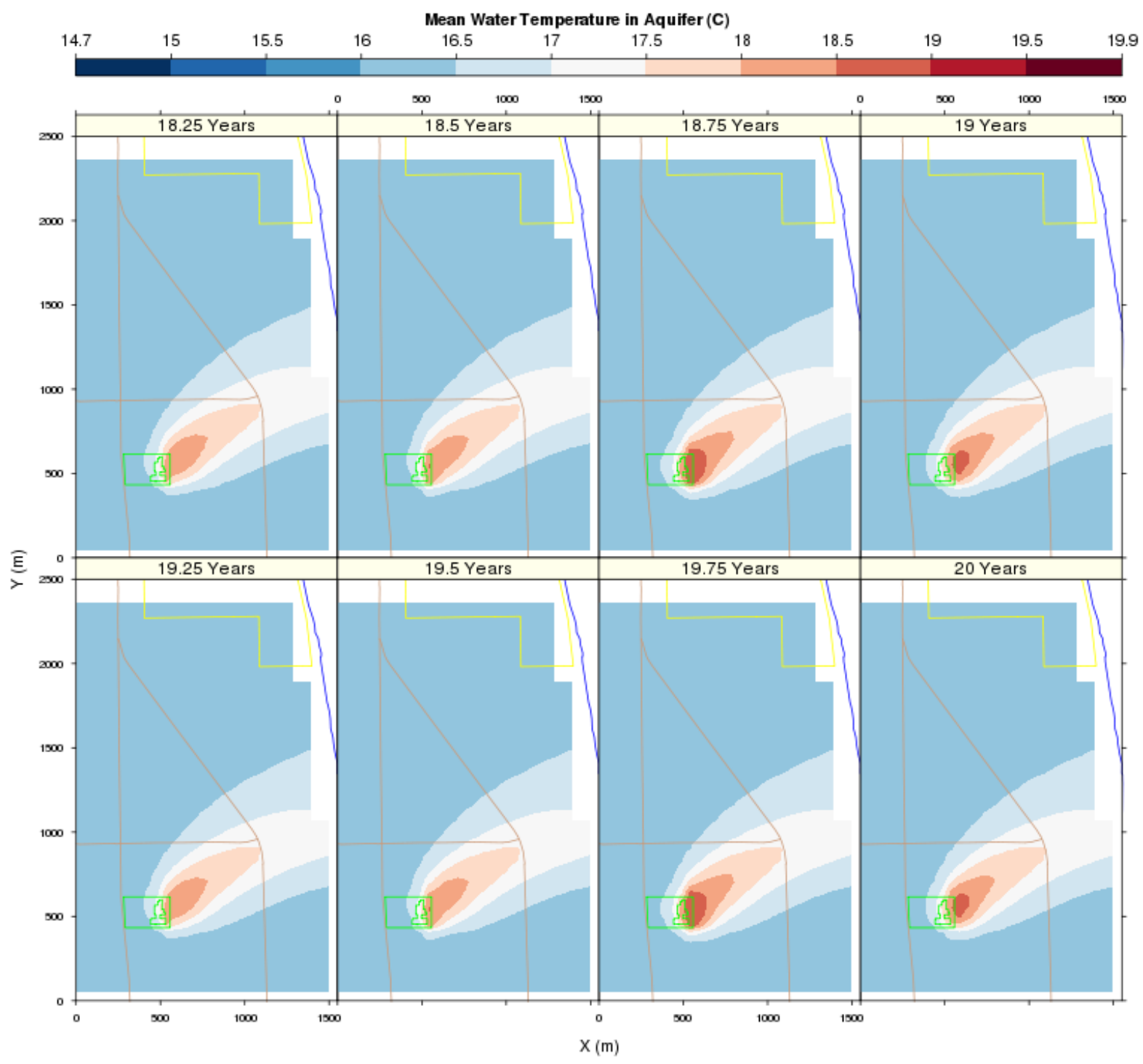

Figure 5.10. Mean Temperature Distribution for Case 2b (Peak Scenario, Ringold Hydraulic Conductivity of $150 \mathrm{~m} / \mathrm{d}$ ) 


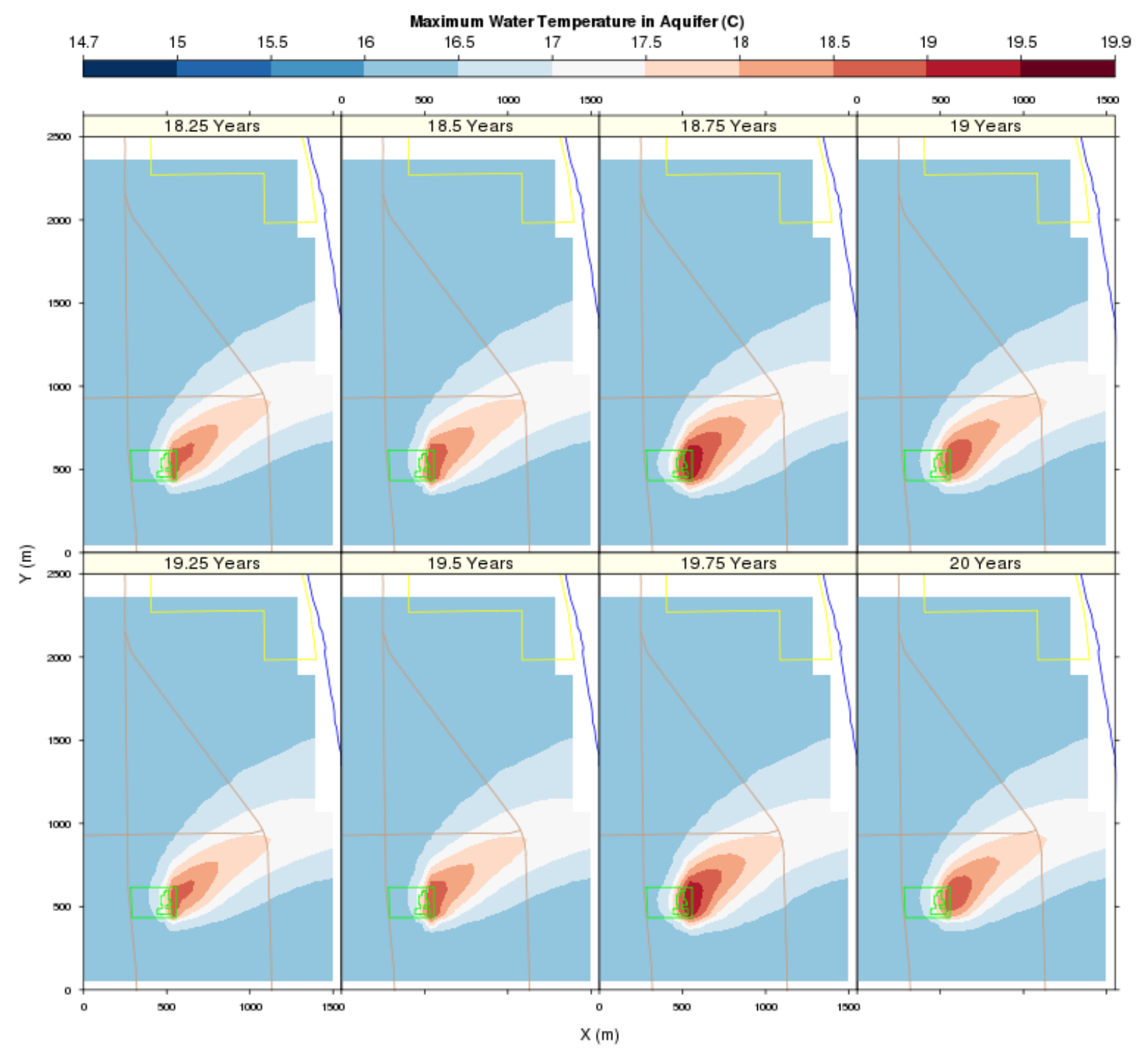

Figure 5.11. Maximum Temperature Distribution for Case 2b (Peak Scenario, Ringold Hydraulic Conductivity of $150 \mathrm{~m} / \mathrm{d}$ )

Figure 5.12 plots maximum temperatures along the shoreline for the two hydraulic conductivity cases. The locations of the maximum temperatures differed between Cases 1 and 2. These results demonstrate that when continuous heat rejection occurs to the groundwater under average operating conditions (Cases $1 \mathrm{a}$ and $2 \mathrm{a}$ ), the maximum temperature change along the eastern boundary is $+0.65^{\circ} \mathrm{C}$ from ambient (solid line). When a month-long peak is considered (dashed line, corresponding to Cases $1 \mathrm{~b}$ and $2 \mathrm{~b}$ ), the maximum temperature change is $+0.9^{\circ} \mathrm{C}$ from ambient. Note that an earlier breakthrough occurs for the lower hydraulic conductivity case because it is located in the upper part of the profile in the Hanford formation. The peak temperature location for Cases 2 occurs deeper in the profile in the Ringold Formation. 


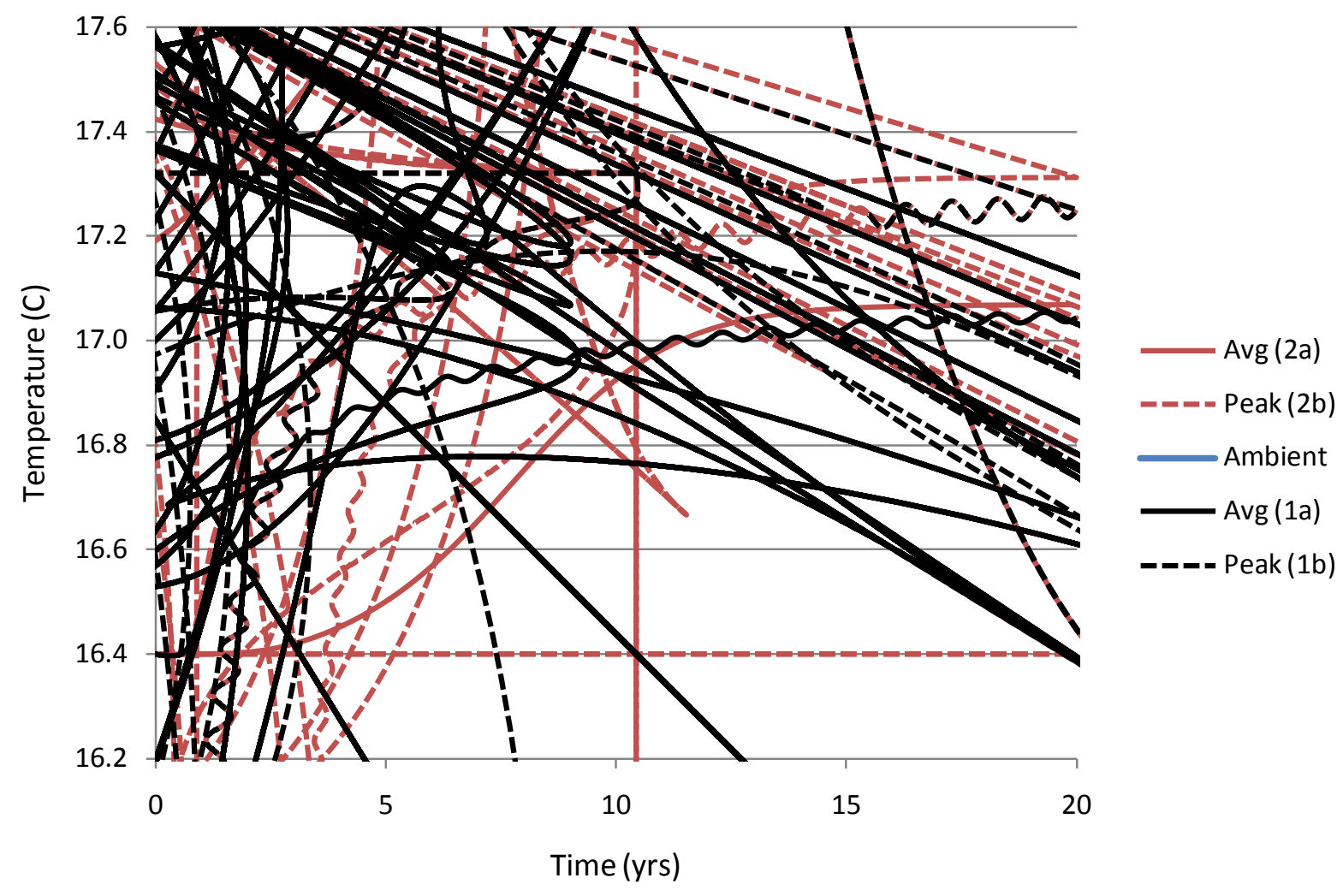

Figure 5.12. Maximum Groundwater Temperatures Near the Columbia River Shoreline for Ringold Hydraulic Conductivities of 60 m/d (Cases 1a,1b) and 150 m/d (Cases 2a,2b). Ambient groundwater temperature at the BSF/CSF Site is plotted for reference.

Although these results demonstrate a maximum change in temperature of $0.9^{\circ} \mathrm{C}$ from ambient, this result does not consider river water intrusion along the shoreline. Additionally, the $0.9^{\circ} \mathrm{C}$ simulated maximum change in temperature in groundwater (upgradient of the shoreline) is also within the natural daily variability of groundwater temperatures that have been measured at the 300 Area, just north of the project site. Temperature data collected at 15-minute intervals for aquifer tubes located along the shoreline in the 300 Area show that temperature fluctuations are highly variable (Figure 5.13), with diurnal fluctuations as high as $5^{\circ} \mathrm{C}$. A $5^{\circ} \mathrm{C}$ diurnal fluctuation is more than five times the amount of temperature increase that is simulated to occur in groundwater upgradient of the hyporheic zone. 


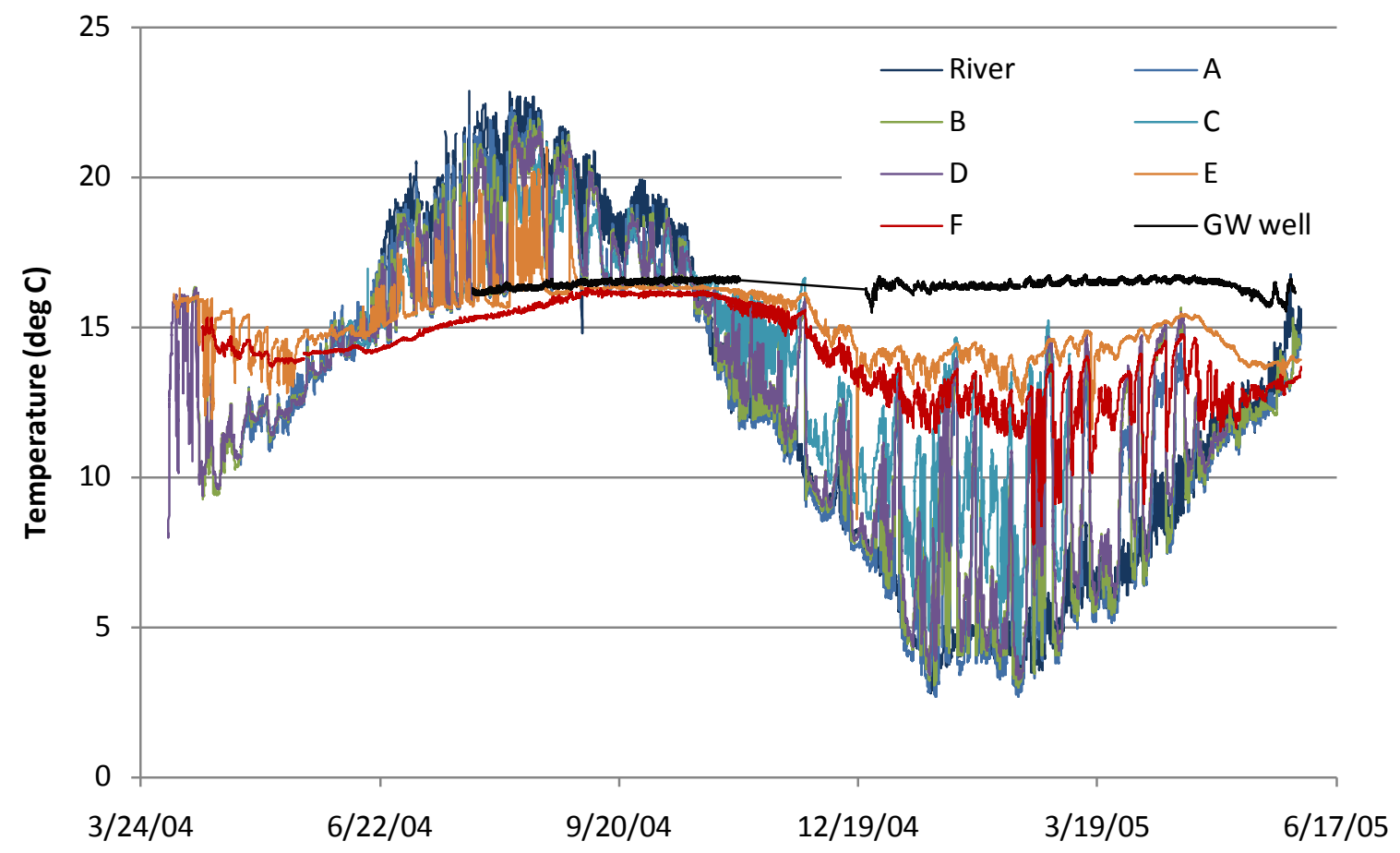

Figure 5.13. Temperature Variability in the Hyporheic Zone Along the 300 Area Shoreline. The average groundwater temperature at the $\mathrm{BSF} / \mathrm{CSF}$ site is $16.4^{\circ} \mathrm{C}$.

The time-series of temperatures shown in Figure 5.12 are for only a few points along the shoreline, but are not necessarily representative of the entire horizontal and vertical distribution of temperatures. Figure 5.14 plots the total groundwater flux for the entire eastern boundary of the domain at year 20. In addition, groundwater fluxes at two threshold temperatures were plotted. The proportion of groundwater flux at temperatures greater than $16.5^{\circ} \mathrm{C}$ was selected because it is just above ambient $\left(16.4^{\circ} \mathrm{C}\right)$. A second threshold value of 17.0 was also plotted in Figure 5.14. The warmest fluxes at $17.3^{\circ} \mathrm{C}$ were also examined, but were too small to be visible in the figure. For Case $2 b$ (Peak scenario, Ringold hydraulic conductivity $150 \mathrm{~m} / \mathrm{d}$ ), the bar graph shows that the proportion of groundwater discharging at temperatures $\geq 16.5^{\circ} \mathrm{C}$ relative to the total groundwater flux in the model ranges from 16 to $18 \%$. The groundwater flux discharging at temperatures $\geq 17.0$ is $2 \%$ for the average scenarios, and $7 \%$ for the peak scenarios. For the peak temperature of $17.3^{\circ} \mathrm{C}$, this temperature is only reached in Case $2 \mathrm{~d}$ and is only $0.2 \%$ of the total groundwater flux along the shoreline. 


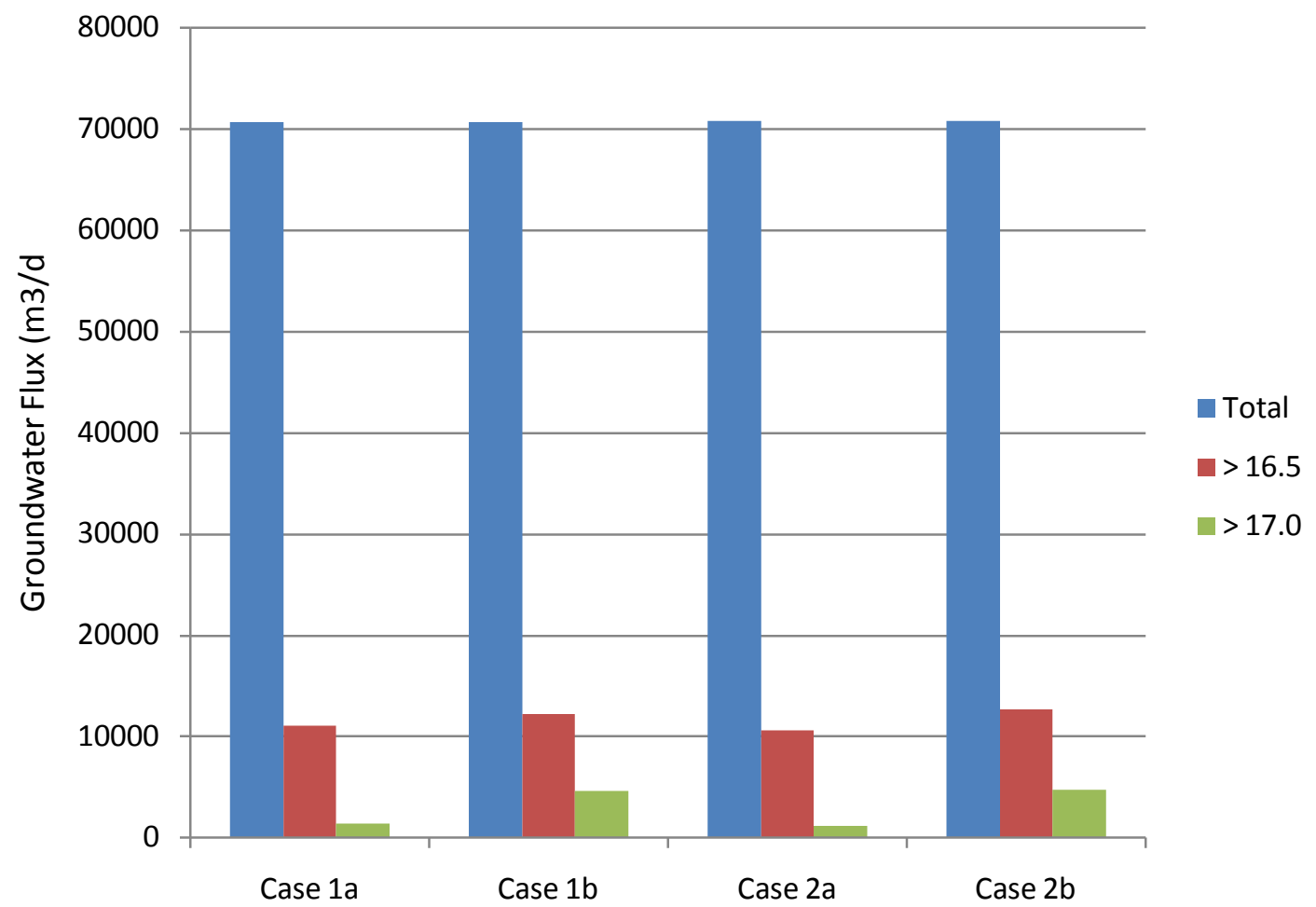

Figure 5.14. Groundwater Fluxes at the Eastern Boundary of the Domain for All Scenarios. Total flux along the boundary is shown in blue, flux Greater than $16.5^{\circ} \mathrm{C}$ in red, and flux greater than $17.0^{\circ} \mathrm{C}$ in green.

\subsubsection{Travel Time to the River}

For the upper estimate of hydraulic conductivity $(150 \mathrm{~m} / \mathrm{d})$, the earliest breakthrough of the thermal plume occurs at $\sim 4$ months, whereas early breakthrough for the lower estimate $(60 \mathrm{~m} / \mathrm{d}$ ) is at $\sim 6$ months. Average travel times are estimated at 9 and 10 months for the upper and lower hydraulic conductivity estimates, respectively.

\subsubsection{Uncertainty in Thermal Transport Results}

There are many sources of uncertainty in the modeling, including the conceptual model and the hydraulic and thermal properties. Sensitivity analyses not reported here have demonstrated that the temperature predictions along the shoreline are not very sensitive to changes in the thermal parameters. And even though a range of hydraulic conductivity estimates was used to assess temperature impacts in the groundwater, the range of predicted temperatures for the two cases differs by only a few tenths of a degree Celsius. To help address uncertainties with respect to the heterogeneities in the Ringold Formation, a high estimate of hydraulic conductivity was used to provide a conservatively high set of temperature estimates in this analysis.

There is also uncertainty associated with the potential for preferential flow into the Hanford formation since injection well screens extend into the Hanford formation. For the simulations presented in this report, screens were set by elevation, and extended partially into the Hanford formation. Hence, the 
impact of injection water travelling in the Hanford has been captured to a limited extent. Even with the injection into the Hanford, simulation results show a small amount of mounding on only a very localized scale (within tens of meters of the injection wells). At the shoreline, the highest temperatures for Cases $1 \mathrm{a}$ and $1 \mathrm{~b}$ are located in the Hanford formation.

Despite these uncertainties, a far greater controlling influence on the predicted groundwater temperatures near the river shoreline is the operating scenario for the GSHP system that is assumed for modeling purposes. Simulation results have demonstrated that temperature predictions along the shoreline are most sensitive to the amount of energy assumed to be rejected to the subsurface. In the winter months, heat generated by laboratory and computer equipment will be redistributed to other parts of the building requiring heat, which will reduce the amount of heat rejected to groundwater. When temperatures fall below $45^{\circ} \mathrm{F}$, only the chiller will operate, and the GSHP will not be operated. In the summer months, the chiller will operate in conjunction with the GSHP, which will also potentially reduce the amount of heat rejected to groundwater.

To account for uncertainties in the winter when the GSHP will not be operational, the well system was shut down for only two months in the winter even though historical meteorological data demonstrate that temperatures fall below $45^{\circ} \mathrm{F}$, on average, for 4.4 months per year. The GSHP, when operational, is also not expected to operate continuously, 24 hours per day, 7 days per week, as simulated in this report. Hence, temperature predictions are considered conservative with respect to uncertainties.

\subsubsection{Summary of Thermal Impacts}

The objective of the heat transport analysis was to identify potential thermal impacts to the Columbia River under likely operational scenarios for the BSF/CSF well field. Estimated pumping rates and injection temperatures were used to simulate heat transport for a range of hydraulic conductivity estimates for the Ringold Formation.

Results demonstrated that temperatures predicted at the shoreline were driven by the source term. For example, the highest conductivity estimates transported heat more quickly to the shoreline, and formed a narrow, more concentrated thermal plume. When these scenarios included a month-long peak (for both pumping rates and injection temperatures), results showed that relative to the average operational scenarios, groundwater temperatures at the shoreline increased by a small measure $\left(\sim+0.25^{\circ} \mathrm{C}\right)$.

The maximum change in temperature at the shoreline was $0.9^{\circ} \mathrm{C}$. However, several conservative assumptions were incorporated into this analysis, the most conservative of which is the time-invariant boundary for flow at the shoreline. With a static boundary condition, no mixing of ground water and river water occurs in the near shore mixing zone. Data collected at the nearby 300 Area shows that diurnal fluctuations in temperature in the hyporheic zone wells are as high as $5^{\circ} \mathrm{C}$ (see Figure 5.13 ). The static boundary conditions also impact prediction results since spreading of the thermal plume is likely reduced. Small changes in groundwater flow directions will increase the mixing zone as energy is transported downgradient.

In addition to a static flow boundary, the energy boundary condition for the shoreline was also static. Shoreline temperatures were represented at the ambient groundwater temperature for the BSF/CSF site 
$\left(16.4^{\circ} \mathrm{C}\right)$. The temperature in the Columbia River varies from varies from $4^{\circ} \mathrm{C}$ to $20^{\circ} \mathrm{C}$ throughout the year, and is less than the ambient temperature for $\sim 8$ months of the year (see Figure 2.9 and Figure 5.13).

The simulation of two consecutive 12-hour peaks in a single month for operational conditions that are likely to occur on an hourly basis was another conservative assumption in this analysis. Moreover, assuming peaks occur for 12 hours per day is highly conservative, since peaks usually occur for 6 hours per day. Since the GSHP will not be operated at temperatures below $7.2^{\circ} \mathrm{C}\left(45^{\circ} \mathrm{F}\right)$, injection and extraction, wells were assumed to shut down for the two coldest months of the year (December and January). Historical meteorological data demonstrates that this is a highly conservative estimate of the time that the pumps will not be operational, since a 54-year record shows that this temperature condition is met from 3.7 to 5.0 months per year. These assumptions result in higher temperatures predicted at the shoreline than what will likely be observed in the field. The use of a volumetric source term to represent the wells in the energy transport simulations meant that injected water immediately spread $50 \mathrm{~m}$, which is 200 times the width of a 0.25 -m well casing. This resulted in conservative (shorter) travel time estimates to the Columbia River, and subsequently higher temperature estimates than what will likely be observed in the field.

With a conservative conceptual model and operational scenarios, the predicted changes in temperature at the shoreline are still well within the natural variability of temperatures observed in shoreline wells. Hence, thermal impacts to the Columbia River are not considered to be significant even under continuous heat rejection operations of the BSF/CSF well field. 


\subsection{Summary of Findings}

\subsection{Introduction}

This section of the hydrogeologic report has been prepared by GSI Water Solutions, Inc. (GSI), in support of Ground Water Application and Preliminary Permit G4-35179 for non-consumptive groundwater use at the PNNL campus in Richland, Washington. The intended beneficial use of the water is for heating and cooling purposes at the new BSF/CSF facilities at the PNNL campus in Richland, Washington. Heating and cooling will occur by operating an open-loop GSHP that pumps groundwater from the western side of the BSF/CSF property and injects it along the eastern property boundary. All pumped groundwater will be routed into the BSF/CSF heating and cooling system and then re-injected into the same geologic units - primarily the Ringold Formation - from which it is extracted. Based on field testing results, sustainable pumping rates for extraction wells $1,2,3$, and 4 are estimated at 600,400 , 100, and 300 gpm, respectively, for a total of 1,400 gpm. Maximum short-term pumping rates from wells 1, 2, 3, and 4 are estimated at 700, 600, 200, and 400 gpm, respectively, for a total of 1,900 gpm. Given that injection will mostly occur in the upper sandy gravel unit of the Ringold Formation, with some mounding into the overlying Hanford formation, injection rates will likely only be limited by maintenance issues, such as well-screen plugging.

GSI has been hired by the permittee, Battelle, as the Project Hydrogeologist in accordance with the requirements of Condition III of the Preliminary Permit that was issued by the Washington Department of Ecology (Ecology) on January 22, 2009. In accordance with Condition V.6 of the Preliminary Permit, GSI has prepared this section of the report to provide a professional opinion regarding 1 ) whether the proposed use of groundwater is non-consumptive in nature, 2) the project's potential to affect existing offsite groundwater contamination, and 3) the potential thermal impacts of the project on the Columbia River. PNNL has prepared this final hydrogeologic report to address these matters and additional questions raised by Ecology regarding potential thermal impacts on the Columbia River.

This chapter of the final report summarizes the findings of the analyses for each of these three questions and then presents GSI’s professional opinion regarding each question.

\subsection{Nature of Groundwater Use}

An open-loop GSHP system has been designed to bring groundwater directly into a heat exchanger. Groundwater that is pumped by extraction wells on the western edge of the BSF/CSF property will be circulated through the heat exchanger, and this entire volume of pumped groundwater will then be injected along the eastern edge of the BSF/CSF property. Because the system will be re-injecting all groundwater that is extracted from the subsurface, the water use is non-consumptive in nature.

Additionally, the modeling analyses presented in this final report illustrate that changes in the height of the water table are unlikely to be greater than approximately 0.01 meter at the location of the nearest groundwater user (the City of Richland). This means that any such change induced by the GSHP system would be indiscernible from water level fluctuations that currently arise from variable well field pumping, changes in river stage, and ambient changes in groundwater elevations and therefore have no potential adverse effect on the ability of the City to operate its wells. 


\subsection{Potential to Affect Offsite Groundwater Contamination}

Detailed information on the locations and characteristics of nearby contaminant plumes, including plume maps, can be found in Appendix A. This information was summarized from the Hanford Site Groundwater Monitoring Report for Fiscal Year 2007 (DOE/RL 2008). The principal areas where groundwater contamination is present are the DOE Horn Rapids landfill, which is located 1.2 kilometers north and west of the BSF/CSF site, and the Hanford 300 area, which is located 1.5 kilometers north of the BSF/CSF site. Contaminants that are presumed to have originated from the AREVA site are in the same location as the DOE Horn Rapids Landfill and are considered as a single site in this analysis.

The potential for GSHP system operations to affect offsite groundwater contamination was analyzed using PNNL's STOMP software. Specifically, STOMP-W was used to evaluate whether groundwater flow paths would be altered in the vicinity of the regional contaminant plumes near the DOE Horn Rapids landfill and the Hanford 300 area. The analysis was conducted using a year-round continuous GSHP system operation rate of 1,400 gpm and repeated for the peak-day pumping rate of 1,900 gpm. Particle tracking analyses with and without pumping qualitatively assessed the zone of influence under both operating conditions. Capture zone analyses using flow path particle-tracking techniques indicate that the BSF/CSF well network has a localized zone of influence under both sets of system operating rates. Specifically, the model simulated that 1 ) both the drawdown cone around the extraction wells and the hydraulic mound around the injection wells would have limited areal extent and 2) groundwater in the vicinity of the DOE Horn Rapids landfill and the Hanford 300 area would continue moving in the same directions as currently occurs without BSF/CSF system operations. These analyses indicate that system operations are unlikely to affect existing offsite groundwater contaminant plumes, a finding that is reinforced by field testing data that indicate the system is likely to operate at lower rates.

Additionally, for a peak GSHP system operation rate of 1,900 gpm, 1) the radius of influence created by the four GSHP extraction wells is unlikely to exceed approximately 600 meters, and 2) the amount of drawdown of the water table outside of the extraction wells' combined capture zone likely will be no greater than approximately 0.6 meters. These findings indicate that groundwater flow paths are not expected to be altered at distances greater than about 600 meters from the extraction well field. At most times, the radius of influence created by the four extraction wells will be even smaller because the system will normally operate at lower rates, whereas the simulated rate of 1,900 gpm is a maximum system operating rate that is expected to be reached for only a few hours a day and only on certain days during the summer-time peak cooling season. As a result, the offsite contaminant plumes at the DOE Horns Rapids Landfill and the Hanford 300 area are not expected to be affected by GSHP system operations because the contaminant plumes from these sites lie 200 meters north of the largest conservatively estimated GSHP radius of influence estimated by the model.

\subsection{Potential for Thermal Plumes to Impact the Columbia River}

PNNL has conducted extensive numerical modeling of potential thermal impacts with a sophisticated thermal transport module built into STOMP and using detailed information on the likely heating and cooling operations for the BSF and CSF buildings. A summary of these operations and the resulting flow rates and temperatures for water injection on the east side of the property are presented below, followed by a summary of the subsurface modeling work that was conducted to estimate potential thermal impacts at the river that could arise from system operations. 


\subsubsection{GSHP Injection Rates and Temperatures}

The analysis of potential thermal impacts to the Columbia River uses the results of a separate modeling analysis of likely facility cooling and GSHP well field operations. The facility operations model provided estimates of flow rates and temperatures that can be expected each month for the water being re-injected along the eastern (downgradient) side of the facility. The facility operations model optimizes energy efficiency, thermal comfort, and cost-effectiveness, as calculated using the system design, the different cooling and heating needs of the BSF and CSF facilities, and 54 years of historical climatic (outdoor air temperature) data. For each month, the predicted flow rates and temperatures from the operations model are 1) the average for the month and 2) the estimated peak value for that month. While the peak value in any given month will only be reached for a few hours of the day when heating (or cooling) needs are at a maximum, the groundwater modeling analysis of thermal impacts conservatively assumes that the peak value will last for 12 hours. Two 12-hour peak periods were assumed by simulating peak operating conditions for an entire month.

The BSF/CSF facility is not expected to be fully operational for another 5 years. Only the continuous heat rejection scenario is presented for the water right. Temperatures of injection water are expected to range 18.9 to $19.9^{\circ} \mathrm{C}$.

\subsubsection{Subsurface Thermal Plume (Heat Transport) Modeling}

The multi-phase STOMP convective-conductive heat flow simulator was used to simulate the effects on groundwater flow patterns and temperatures of groundwater extraction along the west side of the BSF/CSF property and return-flow injection along the east side of the property. STOMP was selected for use in this project because of its capability to simulate saturated and unsaturated flow under nonisothermal conditions. The model evaluated thermal plume effects for a range of aquifer hydraulic conductivity values (60 and $150 \mathrm{~m} / \mathrm{d}$ ) and for the average and peak flow rates and temperatures for the injection water, as derived from historical meteorological (outdoor air temperature) records and the GSHP system operations model. The simulations modeled full-scale operation of the BSF/CSF facility and the GSHP, for which building cooling and subsequent warm-water injection occur year-round. Additionally, the peak-injection scenario assumes peak injection will occur continuously for one month during each year in the model simulation to account for two 12-hour peak periods, even though historical climate records show that air temperatures would have required this injection scheme on fewer days, and for fewer hours each day.

The model results consist of maps of the simulated thermal distribution in the aquifer at multiple times as well as time-series plots of temperatures versus time at locations throughout the model domain. The primary observations that have been drawn from an inspection of the model-simulated temperature maps and time-series plots are as follows:

- Average Operating Conditions. Under average operating conditions, the maximum temperature change in groundwater along the eastern model boundary (near the river shoreline) is $+0.65^{\circ}$ from ambient.

- Peak Operating Conditions. When month-long peaks are considered, the maximum temperature change in groundwater along this boundary $+0.9^{\circ} \mathrm{C}$ from ambient. 
These results do not consider several natural influences that would reduce the amount of temperature increase predicted by the model - in particular, river water intrusion along the shoreline and natural fluctuations in ambient groundwater flow directions. Additionally, the model-predicted changes in groundwater temperature near the river shoreline are 20 percent or less of the range of natural diurnal variability of groundwater temperatures (as much as $5^{\circ} \mathrm{C}$ ) that occurs because of fluctuating river water temperatures.

\subsubsection{Modeling Implications for Potential Thermal Impacts on the Columbia River}

The Columbia River is located approximately 1 kilometer east (downgradient) of the BSF/CSF site. The stage of the river controls groundwater levels near the river, causing flow reversals at times downgradient of the BSF/CSF site. The river flow ranges between 20,000 and 690,000 $\mathrm{ft}^{3} / \mathrm{s}$ with an average flow rate of $120,000 \mathrm{ft}^{3} / \mathrm{s}$ (Waichler et al. 2005). Water levels and temperatures in the Columbia River in the vicinity of the Hanford Site vary seasonally because of precipitation and runoff, and daily because of the operation of the Priest Rapids Dam upstream of the Hanford Site. Temperatures fluctuate seasonally; data from 1991 through 2008 show the monthly average ranged from $4^{\circ} \mathrm{C}$ in February to $20^{\circ} \mathrm{C}$ in August. However, during any given month, river temperatures can vary considerably, as shown by sub-hourly data at near-shore wells that show diurnal temperature variations of up to $5^{\circ} \mathrm{C}$ (see Figure 5.13).

The simulated temperatures along the eastern boundary of the model are not to be interpreted as an absolute temperature prediction for surface water in the Columbia River, but rather as a conservative prediction of the temperature of groundwater in a very localized area near the Columbia River shoreline. The flux rate of groundwater discharging at temperatures exceeding $16.5^{\circ} \mathrm{C}, 17^{\circ} \mathrm{C}$, and $17.3^{\circ} \mathrm{C}$ for the upper estimate of hydraulic conductivity is, respectively, $18 \%, 7 \%$, and $0.2 \%$ of the total groundwater flux to the river along the simulated shoreline length. Additionally, these estimates are likely too high because the model does not account for the transient fluctuations in the water table that are known to occur near the river and which likely attenuate groundwater temperatures near the river (because river water mixes with near-shore groundwater). By assuming that the ambient flow regime for groundwater and the river is a steady-state flow regime, the model ignores groundwater mixing with river water, resulting in conservative simulation results for the estimated temperature impacts in groundwater near the river.

The thermal analysis is conservative and likely overestimates groundwater temperatures near the river. Attributes of the analysis that are conservative and thereby artificially raise the simulated maximum temperature in groundwater are as follows:

- The use of a volumetric source term to represent the wells in the energy transport simulations meant that injected water immediately spread $50 \mathrm{~m}$, which is 200 times the width of a 0.25 -m well casing. This resulted in conservative (shorter) travel time estimates to the Columbia River, and subsequently higher temperature estimates than what will likely be observed in the field.

- Because the model's boundary conditions are static, small variations in the ambient groundwater flow direction are not simulated, which in turn means the model does not simulate as much 
spreading of the thermal plume as will actually occur. Thus, the model simulation concentrates the injected heat over a smaller area in the aquifer than will actually occur.

- No mixing of river water in the near-shore groundwater system is simulated, which is important during those times when river temperatures are lower than the temperature of the ambient groundwater or the water injected at the BSF/CSF site. Additionally, the river is assumed to be at a static temperature $\left(16.4^{\circ} \mathrm{C}\right)$ throughout the year, even though historical data show that actual river temperatures are commonly lower during 8 months of any given year.

- Peak-day temperatures for the water injected at the BSF/CSF site will likely last only a few hours during a given month, but are simulated as lasting one month to account for two 12-hour peak periods.

With a conservative conceptual model and a conservative representation of the operational scenarios in the subsurface heat transport model, the predicted changes in groundwater temperatures near the river shoreline are still within the natural variability of temperatures observed in shoreline wells. Hence, thermal impacts to the Columbia River are not considered to be significant even under a continuous heatrejection scenario for BSF/CSF well field operations.

\subsection{Professional Opinion}

As the Project Hydrogeologist for Preliminary Permit G4-35179, GSI has reached the following findings regarding specific issues raised in Condition V-6 of the Preliminary Permit and specific questions about potential thermal plume impacts on the Columbia River that also have been raised by Ecology:

1. The proposed use of groundwater for this project is non-consumptive in nature. Specifically, all groundwater used in the open-loop GSHP for the BSF/CSF heating and cooling system under this proposal will re-injected into the same geologic units - the Hanford and Ringold formations-from which it is extracted. The modeling simulations provide further evidence of the non-consumptive use of the groundwater resource in that changes in groundwater elevations occur only in very close proximity to the system, with no area-wide decreases in groundwater levels, even under simulated operating rates as high as 1,900 gpm.

2. In-depth numerical modeling analyses indicate that the proposed project is unlikely to affect existing offsite groundwater contamination plumes at the DOE Horn Rapids landfill and the Hanford 300 area. This conclusion is based on model simulations conducted for GSHP system operating rates of 1,400 gpm (average rate) and 1,900 gpm (short-term maximum instantaneous rate); these simulations show that the contaminant plumes at these sites lie $\sim 200 \mathrm{~m}$ beyond the immediate area where GSHP extraction and injection wells are expected to alter groundwater flow patterns.

3. Although Columbia River water will not be captured by the BSF/CSF groundwater system operations, the potential exists for thermal plumes to migrate from the system towards the Columbia River. However, based on the results of a highly conservative heat-transport modeling analysis, changes in groundwater temperatures along the shoreline are likely less than $1^{\circ} \mathrm{C}$ above the average ambient background groundwater temperature of $16.4^{\circ} \mathrm{C}$ that has been measured near the BSF/CSF site. The modeling analysis also indicates that any such temperature increases in groundwater near the river will occur beneath only a very limited length of the river shoreline. Long-term historical 
data for the river and near-shore groundwater indicate that mixing of river water in the near-shore groundwater system will further attenuate temperature changes in groundwater near the river shoreline. Additionally, river temperature data show diurnal temperature fluctuations of up to $5^{\circ} \mathrm{C}$, which is at least five times greater than the temperature change that may arise in near-shore groundwater as a result of GSHP system operations. Therefore, thermal impacts to the Columbia River are not considered to be significant for BSF/CSF long-term well field operations. 


\subsection{References}

Agarwal RG. 1980. “A New Method to Account for Producing Time Effects when Drawdown Type Curves Are Used to Analyze Pressure Buildup and Other Test Data.” SPE Paper 9289, Society of Petroleum Engineers, Dallas, Texas.

Boman GK, FJ Molz, and KD Boone. 1997. "Borehole Flowmeter Application in Fluvial Sediments: Methodology, Results, and Assessment.” Ground Water 35(3):443-450.

Butler JJ, Jr. 2005. "Hydrogeological Methods for Estimation of Spatial Variations in Hydraulic Conductivity.” In: Hydrogeophysics. Y Rubin and S Hubbard (eds.), Springer, The Netherlands.

Bjornstad BN, JA Horner, VR Vermeul, DC Lannigan, and PD Thorne. 2009. Borehole Completion and Conceptual Hydrogeologic Model for the IFRC Well Field, 300 Area, Hanford Site. PNNL-18340, Pacific Northwest National Laboratory, Richland, Washington.

Campbell NP. 1983. “Correlation of Late Cenozoic Gravel Deposits Along the Yakima River Drainage from Ellensburg to Richland, Washington.” Northwest Science 57:179-193.

Cooper HH and CE Jacob. 1946. “A Generalized Graphical Method for Evaluating Formation Constants and Summarizing Well Field History.” Transactions of the American Geophysical Union 27:526-534.

Craig JR and LS Matott. 2008. VISUAL AEM 1.0: A Windows-based graphical user interface for analytic element modeling of groundwater flow and transport, post processing, and analysis. Uses the public domain numerical codes SPLIT, TimML, BLUEBIRD, CARDINAL, and OSTRICH. Available at: http://visual-aem.software.informer.com/1.0/. Accessed 06-03-2009.

DOE/RL-U.S. Department of Energy Richland Operations Office. 1990. Phase 1 Remedial Investigation Report for the Hanford Site 1100-EM-1 Operable Unit. DOE/RL-90-18, Richland, Washington.

DOE/RL—U.S. Department of Energy Richland Operations Office. 2002. Standardized Stratigraphic Nomenclature for the Post-Ringold-Formation Sediments Within the Central Pasco Basin. DOE/RL2002-39, Rev. 0, Richland, WA.

DOE-RL-U.S. Department of Energy Richland Operations. 1992a. Draft Remedial Investigation/Feasibility Study for the 1100-EM-1 Operable Unit, Hanford. DOE/RL-92-67, Vol. 1, Draft B, Richland, Washington.

DOE-RL-U.S. Department of Energy Richland Operations. 1992b. Draft Remedial Investigation/Feasibility Study for the 1100-EM-1 Operable Unit, Hanford. DOE/RL-92-67, Vol. 2. Draft B, Richland, Washington.

DOE/RL-U.S. Department of Energy Richland Operations. 2008. Hanford Site Groundwater Monitoring Report for Fiscal Year 2007. DOE/RL-2008-01, Rev. 0, MJ Hartman, WD Webber, and Fluor Hanford, Inc., eds. Richland, Washington. 
Ferguson G. 2006. "Potential use of particle tracking in the analysis of low-temperature geothermal developments.” Geothermics 35(1):44-58.

Florides G and S Kalogirou. 2007. "Ground heat exchangers—A review of systems, models and applications.” Renewable Energy 32:2461-2478.

Fritz BG, NP Kohn, TJ Gilmore, D McFarland, EV Arntzen, RD Mackley, GW Patton, DP Mendoza, and AL Bunn. 2007. Investigation of the Hyporheic Zone at the 300 Area, Hanford Site. PNNL-16805. Pacific Northwest National Laboratory, Richland, Washington.

Gee GW, ZF Zhang, SW Tyler , WH Albright , and MJ Singleton . 2005. "Chloride-Mass-Balance: Cautions in Predicting Increased Recharge Rates.” Vadose Zone Journal 4(2005):72-78.

Hartman MJ and JA Rediker. 2009. Hanford Site Groundwater Monitoring for Fiscal Year 2008. DOE/RL-2008-66, CH2MHill Plateau Remediation Co., U.S. Department of Energy, Richland, Washington.

Hartman MJ and JA Rediker. 2009. Hanford Site Groundwater Monitoring for Fiscal Year 2008. DOE/RL-2008-66, CH2MHill Plateau Remediation Co., U.S. Department of Energy, Richland, Washington.

Hartman MJ and WD Webber. 2008. Hanford Site Groundwater Monitoring for Fiscal Year 2007. DOE/RL-2008-01, Fluor Hanford, Inc., U.S. Department of Energy, Richland, Washington.

Hartman MJ, LF Morasch, and WD Webber. 2007. Hanford Site Groundwater Monitoring for Fiscal Year 2006. PNNL-16346, Pacific Northwest National Laboratory, Richland, Washington.

Jacob CE. 1963. "Determining the Permeability of Water table Aquifers.” In: Methods of Determining Permeability, Transmissibility, and Drawdown. U.S. Geological Survey, Water-Supply Paper 1536-I:245-271.

Kruseman GP and NA de Ridder. 1990. Analysis and Evaluation of Pumping Test Data (Second ed.). International Institute for Land Reclamation and Improvement, Wagningen, Netherlands.

Liikala TL. 1994. Hydrogeology Along the Southern Boundary of the Hanford Site Between the Yakima and Columbia Rivers, Washington. PNNL-10094, Pacific Northwest Laboratory, Richland, Washington.

Lindsey KA. 1995. Miocene- to Pliocene-Aged Suprabasalt Sediments of the Hanford Site, SouthCentral Washington. BHI-00184, Bechtel Hanford, Inc., Richland, Washington.

Meyer PD, M Ye, ML Rockhold, SP Neuman, and KJ Cantrell. 2007. Combined Estimation of Hydrogeologic Conceptual Model, Parameter, and Scenario Uncertainty with Application to Uranium Transport at the Hanford Site 300 Area. PNNL-16396, Pacific Northwest National Laboratory, Richland, Washington.

Neuman SP. 1972. "Theory of Flow in Unconfined Aquifers Considering Delayed Response of the Water Table.” Water Resources Research 8(4):1031-1045. 
Neuman SP. 1974. "Effect of Partial Penetration of Flow in Unconfined Aquifer Considering Delayed Gravity Response.” Water Resources Research 10(2):303-312.

Neuman SP. 1975. "Analysis of pumping test data from anisotropic unconfined aquifers considering delayed gravity response.” Water Resources Research 11(2):329-342.

Newcomer DR. 2007. Groundwater Monitoring at the 1100-EM-1 Operable Unit. PNNL-16528, Pacific Northwest National Laboratory, Richland, Washington.

Peterson RE and MP Connelly. 2001. Zone of Interaction Between Hanford Site Groundwater and Adjacent Columbia River. PNNL-13674, Pacific Northwest National Laboratory, Richland, Washington.

Peterson RE, EJ Freeman, CJ Murray, PD Thorne, MJ Truex, VR Vermeul, MD Williams, SB Yabusaki, JM Zachara, JL Lindberg, and JP McDonald. 2005. Contaminants 1023 of Potential Concern in the 300FF-5 Operable Unit: Expanded Annual Groundwater Report 1024 for Fiscal Year 2004. PNNL-15127, Pacific Northwest National Laboratory, Richland, Washington.

Peterson RE, ML Rockhold, RJ Serne, PD Thorne, and MD Williams. 2008. Uranium Contamination in the Subsurface Beneath the 300 Area, Hanford Site, Washington. PNNL-17034, Pacific Northwest National Laboratory, Richland, Washington.

Pruess K. 2000. Multiphase Fluid Flow and Heat Transfer at Hanford Single-Shell Tanks - A Progress Report on Modeling Studies. LBNL-45283, Lawrence Berkley National Laboratory, Berkley, California.

R Development Core Team. 2008. "R: A Language and Environment for Statistical Computing.” R Foundation for Statistical Computing, Vienna, Austria. ISBN 3-900051-07-0. Available at: http://www.R-project.org. Accessed 06-02-2009.

Reidel SP, KA Lindsey, and KR Fecht. 1992. Field Trip Guide to the Hanford Site. WHC-MR-0391, Westinghouse Hanford Company, Richland, Washington.

Rockhold ML, MJ Fayer, and GW Gee. 1988. Characterization of unsaturated hydraulic conductivity at the Hanford Site. PNL-6488, Pacific Northwest Laboratory, Richland, Washington.

Schalla R, RW Wallace, RL Aaberg, SP Airhart, DJ Bates, JVM Carlile, CS Cline, DI Dennison, MD Freshley, PR Heller, EJ Jensen, KB Olsen, RG Parkhurst, JT Rieger, and EJ Westergard. 1988. Interim Characterization Report for the 300 Area Process Trenches. PNL-6716, Pacific Northwest Laboratory, Richland, Washington.

Schalla R, RW Wallace, RL Aaberg, SP Airhart, DJ Bates, JVM Carlile, CS Cline, DI Dennison, MD Freshley, PR Heller, EJ Jensen, KB Olsen, RG Parkhurst, JT Rieger, and EJ Westergard. 1988. Interim Characterization Report for the 300 Area Process Trenches. PNL-6716, Pacific Northwest Laboratory, Richland, Washington.

Spane FA, Jr. and DR Newcomer. 2008. Results of Detailed Hydrologic Characterization Tests - Fiscal and Calendar Year 2005. PNNL-17348, Pacific Northwest National Laboratory, Richland, Washington. 
Swanson LC. 1992. Phase 1 Hydrogeologic Summary of the 300-FF-5 Operable Unit, 300 Area. WHC-SD-EN-TI-052, Westinghouse Hanford Corp., Richland, Washington.

Theis CV. 1935. "The relation between the lowering of the piezometric surface and the rate and duration of discharge of a well using groundwater storage.” Transactions of American Geophysical Union, 2, pp. 519-524.

Thorne PD, MP Bergeron, MD Williams, and VL Freedman. 2006. Groundwater Data Package for Hanford Assessments. PNNL-14753, Rev. 1, Pacific Northwest National Laboratory, Richland, Washington.

Thorne PD, MA Chamness, FA Spane, Jr., VR Vermeul, and WD Webber. 1993. Three-Dimensional Conceptual Model for the Hanford Site Unconfined Aquifer System, FY 93 Status Report. PNL-8971, Pacific Northwest Laboratory, Richland, Washington.

Waichler SR and SB Yabusaki. 2005. Flow and Transport in the Hanford 300 Area Vadose ZoneAquifer-River System. PNNL-15125, Pacific Northwest National Laboratory, Richland, Washington.

Waichler SR, WA Perkins, and MC Richmond. 2005. Hydrodynamic Simulation of the Columbia River, Hanford Reach, 1940--2004. PNNL-15226, Pacific Northwest National Laboratory, Richland, Washington.

Ward AL. 2007. Geotechnical, Hydrogeologic and Vegetation Data Package for 200-UW-1 Waste Site Engineered Surface Barrier Design. PNNL-17134, Pacific Northwest National Laboratory, Richland, Washington.

White MD and M Oostrom. 2000. STOMP Subsurface Transport Over Multiple Phase: Theory Guide. PNNL-11216 (UC-2010), Pacific Northwest National Laboratory, Richland, Washington.

White MD and M Oostrom. 2006. STOMP Subsurface Transport Over Multiple Phase: User's Guide. PNNL-15782 (UC-2010), Pacific Northwest National Laboratory, Richland, Washington.

Williams BA, BN Bjornstad, R Schalla, and WD Webber. 2000. Revised Hydrogeology for the Suprabasalt Aquifer System, 200-East Area and Vicinity, Hanford Site, Washington. PNNL-12261, Pacific Northwest National Laboratory, Richland, Washington.

Williams BA, CF Brown, W Um, MJ Nimmons, RE Peterson, BN Bjornstad, DC Lanigan, RJ Serne, FA Spane, and ML Rockhold. 2007. Limited Field Investigation Report for Uranium Contamination in the 300-FF-5 Operable Unit at the 300 Area, Hanford Site, Washington. PNNL-16435, Pacific Northwest National Laboratory, Richland, Washington.

Williams MD, ML Rockhold, PD Thorne, and Y Chen. 2008. Three-Dimensional Groundwater Models of the 300 Area at the Hanford Site, Washington State. PNNL-17708. Pacific Northwest National Laboratory, Richland, Washington.

Yabusaki SB, Y Fang, and SR Waichler. 2008. "Building Conceptual Models of Field-Scale Uranium Reactive Transport in a Dynamic Vadose Zone-Aquifer-River System.” Water Resources Research doi:doi:10.1029/2007WR006617. 
Young SC and HS Pearson. 1995. “The Electromagnetic Borehole Flowmeter: Description and Application.” Ground Water Monitoring and Remediation 15(2):138-146.

Zachara JM, JA Davis, C Liu, JP McKinley, N Qafoku, DM Wellman, and S Yabusaki. 2005. Uranium Geochemistry in Vadose Zone and Aquifer Sediments from the 300 Area Uranium Plume. PNNL-15121, Pacific Northwest National Laboratory, Richland, Washington. 



\section{Appendix A}

\section{Regional Contaminant Plumes}




\section{Appendix A: Regional Contaminant Plumes}

The Biological Sciences Facility (BSF) and the Computational Sciences Facility (CSF) are located on the west side of the Pacific Northwest National Laboratory (PNNL) Campus 300 meters south of the Hanford Site boundary (see Figure A.1). The southern border of the 300 Area is located $\sim 1.5 \mathrm{~km}$ north of the site, the AREVA facilities are $1.2 \mathrm{~km}$ to the west, and the U.S. Department of Energy (DOE) Horn Rapids Landfill is $\sim 1.2 \mathrm{~km}$ northwest of the site. The proximity of these areas is of primary concern to the proposed ground source heat pump (GSHP) because they have been identified as areas with existing contaminant plumes. These contaminants include uranium, tritium, nitrate, and volatile organic compounds such as cis-1,2-dichloroethene (DCE), trichloroethene (TCE), and tetrachloroethene (PCE). Ammonia, gross alpha, gross beta, and technetium-99 were also detected in the groundwater samples from monitoring wells in the surrounding areas. Although tritium is not a contaminant of concern in nearby areas, a brief discussion of the size and persistence of the tritium plume is also provided.

All of the data presented in this report are summarized from the Hanford Site Groundwater Monitoring Report for Fiscal Year 2007 (FY07) (DOE/RL 2008).

\section{A.1 The 300 Area}

The Hanford 300-Area is adjacent to the Columbia River in the southern section of the 570-squaremile Hanford Site approximately 1.5 kilometers from the BSF/CSF site. From 1943 to the mid-80s, DOE fabricated nuclear reactor fuel in the 300-Area. An estimated 27-million cubic yards of solid and dilute liquid wastes containing radioactive, mixed, and hazardous constituents were disposed of in ponds, trenches, and landfills in the 300-Area.

\section{A.1.1 Uranium}

The contaminant of greatest concern in groundwater beneath the 300 Area is uranium. Uranium was introduced to groundwater by disposal of fuel fabrication effluent to waste facilities. Residual uranium still exists in the vadose zone and aquifer and is strongly sorbed onto sediment particles. Water sample analyses collected from the upper portion of the unconfined aquifer show that concentrations in the plume vary seasonally in response to Columbia River conditions. According to the data from wells where groundwater has not been influenced by waste disposal, natural background concentrations for uranium in the 300 Area range from 3 to $8 \mu \mathrm{g} / \mathrm{L}$. For the Hanford Site, natural background for uranium in groundwater ranges from 0.5 to $12.8 \mu \mathrm{g} / \mathrm{L}$. The area where uranium-contaminated ground water exceeds the drinking water standard of $30 \mu \mathrm{g} / \mathrm{L}$ has remained consistent over years of monitoring, covering $\sim 0.4$ to 0.5 square kilometers, and contains $\sim 45$ to 77 kilograms of dissolved uranium.

The results of the groundwater sampling at several sites located along the shoreline show high levels of uranium concentrations ( 90 to $200 \mu \mathrm{g} / \mathrm{L}$ ) (see Figure A.2). The highest values were reported from the sites adjacent to the central core area of the groundwater plume. Uranium concentrations in groundwater at locations near the Columbia River are reduced by infiltrating river water during high river stage conditions. Reports show that since January 2006, concentrations have been decreasing steadily to values approximately one-half the drinking water standard. Uranium concentrations in samples from the wells 
that have open intervals below the saturated Hanford sediment are typically near background levels. No uranium has been found in the fine-grained subunit of the Ringold Formation.

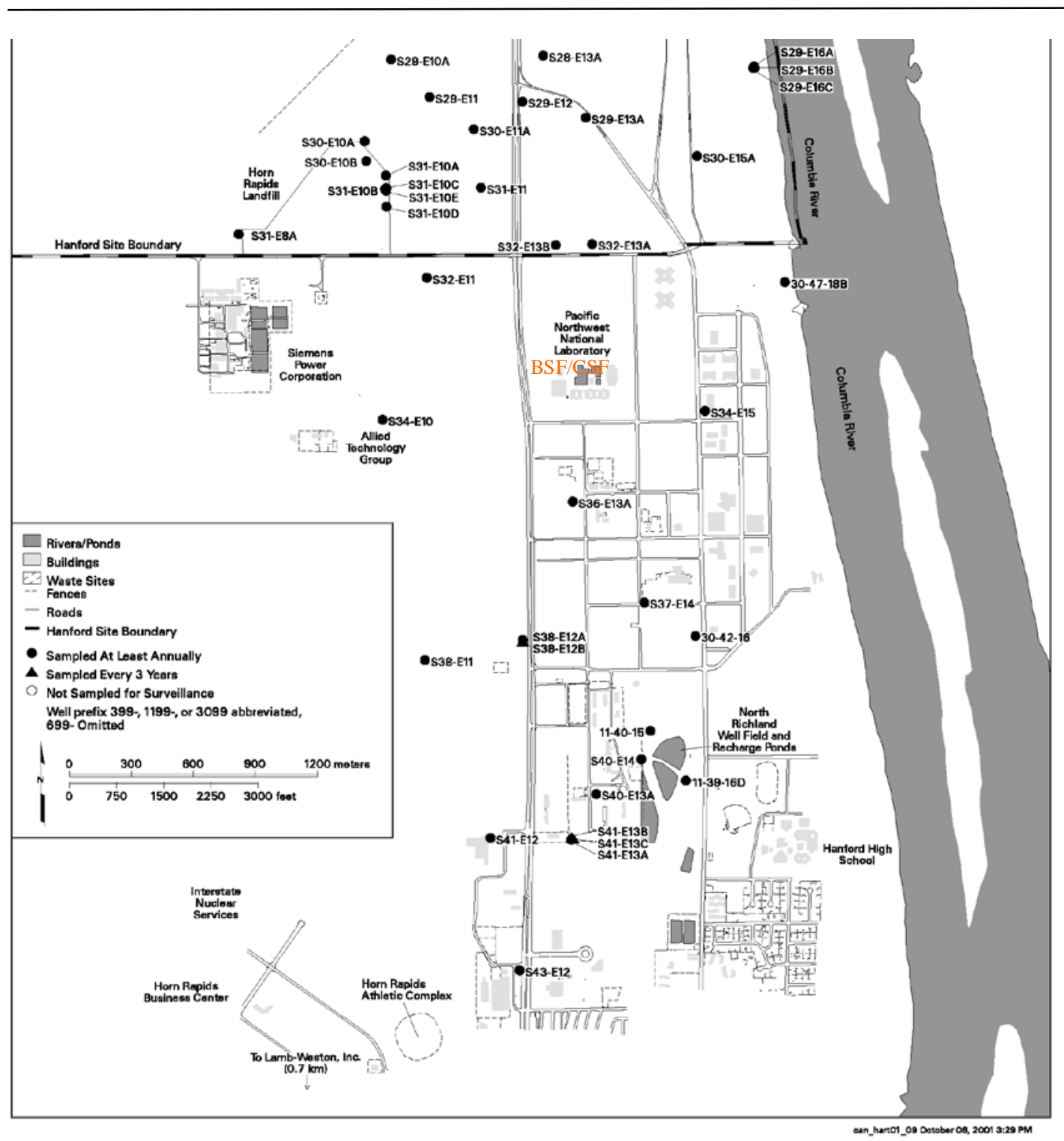

Figure A.1. Map of North Richland

\section{A.1.2 Nitrate}

Nitrates were discharged into the subsurface during the periods of disposal of operations-related effluent and sanitary sewer systems. In the past (throughout 1970s and 1980s), nitrate concentrations in groundwater beneath the 300 Area were higher than current concentrations, but never significantly above the drinking water standard. 


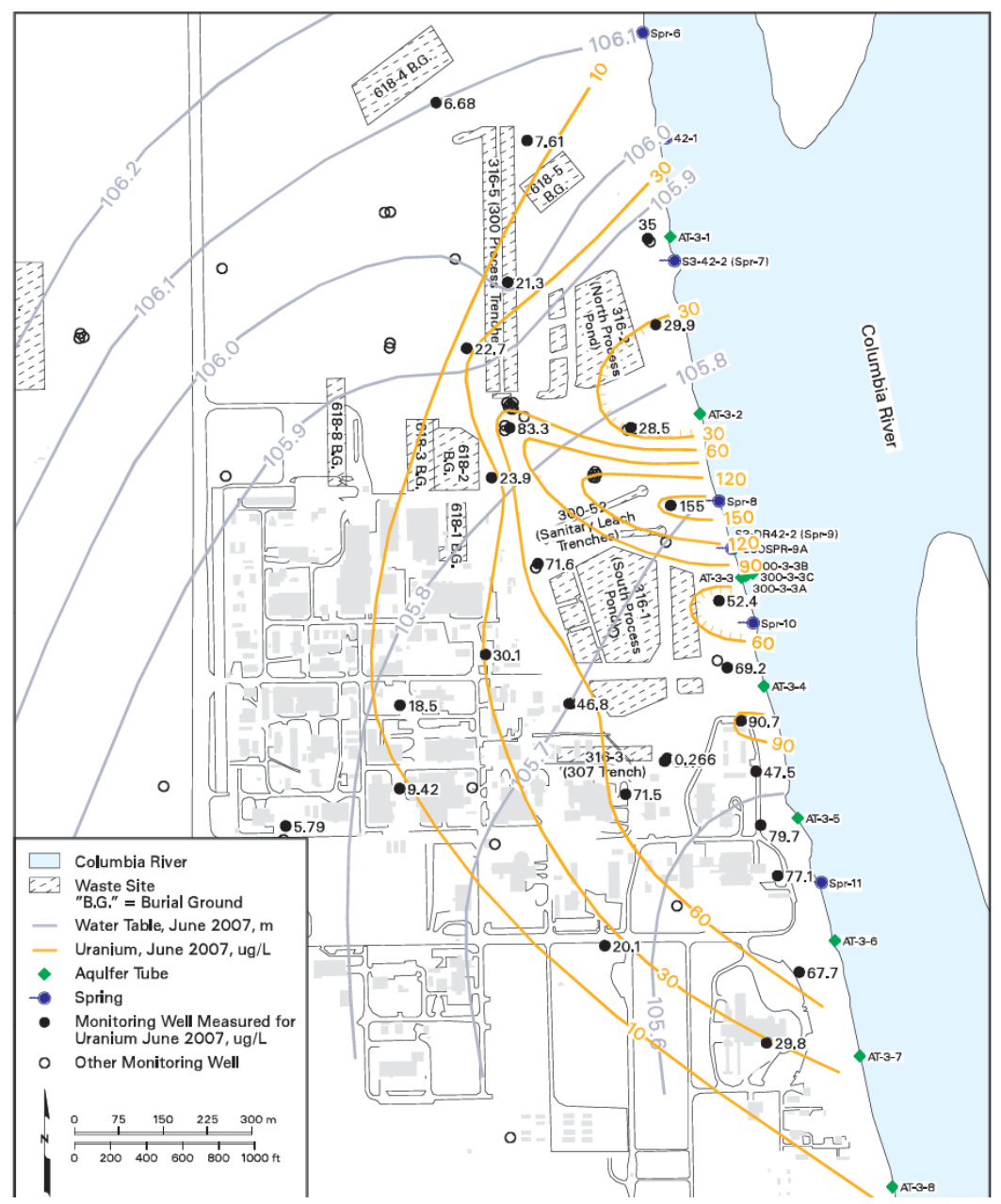

Figure A.2. Uranium Concentrations in Upper Part of Unconfined Aquifer Beneath the 300 Area, December 2006

\section{A.2 Trichlorethylene (TCE)}

During FY07, TCE contamination was detected in the groundwater at the water table in the central and southern portions of the 300 Area $(0.27$ to $0.40 \mu \mathrm{g} / \mathrm{L})$. However, TCE concentrations are significantly below the drinking water standard $(5 \mu \mathrm{g} / \mathrm{L})$.

Dichloroethene (DCE) is a decomposition product of TCE, and PCE and has been present in the sandy subunit and lower portion of the unconfined aquifer along the downgradient flow path from the former 300 Area process trenches at concentrations that exceed the $70-\mu \mathrm{g} / \mathrm{L}$ drinking water standard. Concentrations at this location initially increased during monitoring in the 1990s, followed by a period of stabilization, and then increased variability in 2005. The cause for this behavior has not yet been identified. 


\section{A.3 Richland North Area}

Probable sources of groundwater contamination that originated from the Richland North Area (see Figure A.1) include AREVA (Siemens Power Corporation), agricultural irrigation, and the Lamb-Weston Richland Plant. AREVA is located adjacent to the Hanford Site boundary southwest of DOE's Horn Rapids Landfill, and a surface impoundment system at the site contributed to solvent and nitrate contamination in groundwater. Fertilizers applied to the agricultural fields upgradient (south) of AREVA and potato-processing waste from the Lamb-Weston Richland Plant are probable sources of nitrate. DOE's Horn Rapids Landfill is a source of organic solvent compound contamination of groundwater in the immediate vicinity of the landfill. This contamination is currently not affecting groundwater in the Richland North Area or the Hanford Site.

TCE contamination is suspected to be the result of offsite industrial solvent use at AREVA. Solvents were used during installation, cleaning, and repairing of lagoon liners over a 10-year period between 1978 and 1988. Excess solvents entered the soil by spillage and were driven down into the vadose zone and reached groundwater, which is very shallow in this area. On reaching groundwater, TCE was very mobile and formed a localized plume that migrated downgradient to the northeast across DOE's Horn Rapids Landfill. The highest concentrations were found near AREVA and DOE's Horn Rapids Landfill. The DOE Horn Rapids Landfill was used in the 1950s to 1970s for asbestos disposal and was closed in accordance with asbestos regulations.

During FY07, elevated levels of uranium were found downgradient of the AREVA industrial facility near DOE’s inactive Horn Rapids Landfill. The highest measured concentration was 119 pCi/L $(172 \mu \mathrm{g} / \mathrm{L})$. Groundwater sample data from wells downgradient from the Horn Rapids Landfill indicate that uranium concentrations remain below the drinking water standards at $\sim 23 \mu \mathrm{g} / \mathrm{L}$ (Figure A.3).

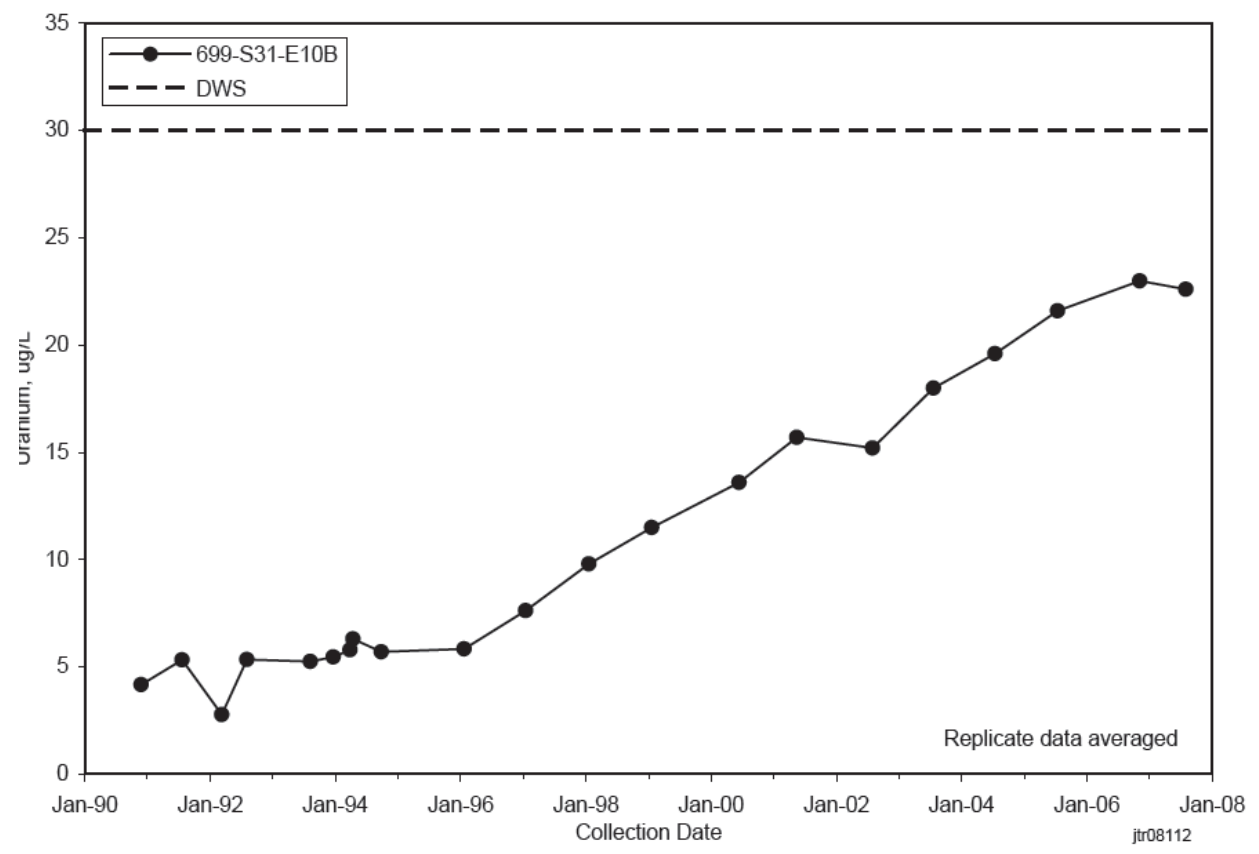

Figure A.3. Uranium Concentrations near DOE Inactive Horn Rapids Landfill 


\section{A.3.1 Nitrate}

High levels of nitrate occur $\sim 2 \mathrm{~km}$ northwest of the BSF/CSF facility. These concentrations resulted from industrial and agricultural uses, such as the application of fertilizers on irrigation circles. Nitrate concentrations above the drinking water standard occur over much of the area that lies $\sim 1.2 \mathrm{~km}$ northwest of the BSF/CSF facility. Groundwater concentrations measured in FY07 showed concentration increases in a number of wells (Figure A.4). Some of the highest nitrate levels were detected near AREVA and DOE's Horn Rapids Landfill ( $\sim 370 \mathrm{mg} / \mathrm{L}$ ). The configuration of the nitrate plume in this area indicates that nitrate continues to migrate in a northeast direction toward the 300 Area and discharges to the Columbia River just below the 300 Area.

\section{A.3.2 Ammonium}

Concentrations of ammonia in wells located downgradient of the AREVA facility generally remained steady in FY07 with the highest average concentration reported as $12.6 \mathrm{mg} / \mathrm{L}$ (as $\mathrm{NH}_{3}$ ). The drinking water standard for ammonia has not been established. Ammonia is typically oxidized to nitrate by bacterial action. 


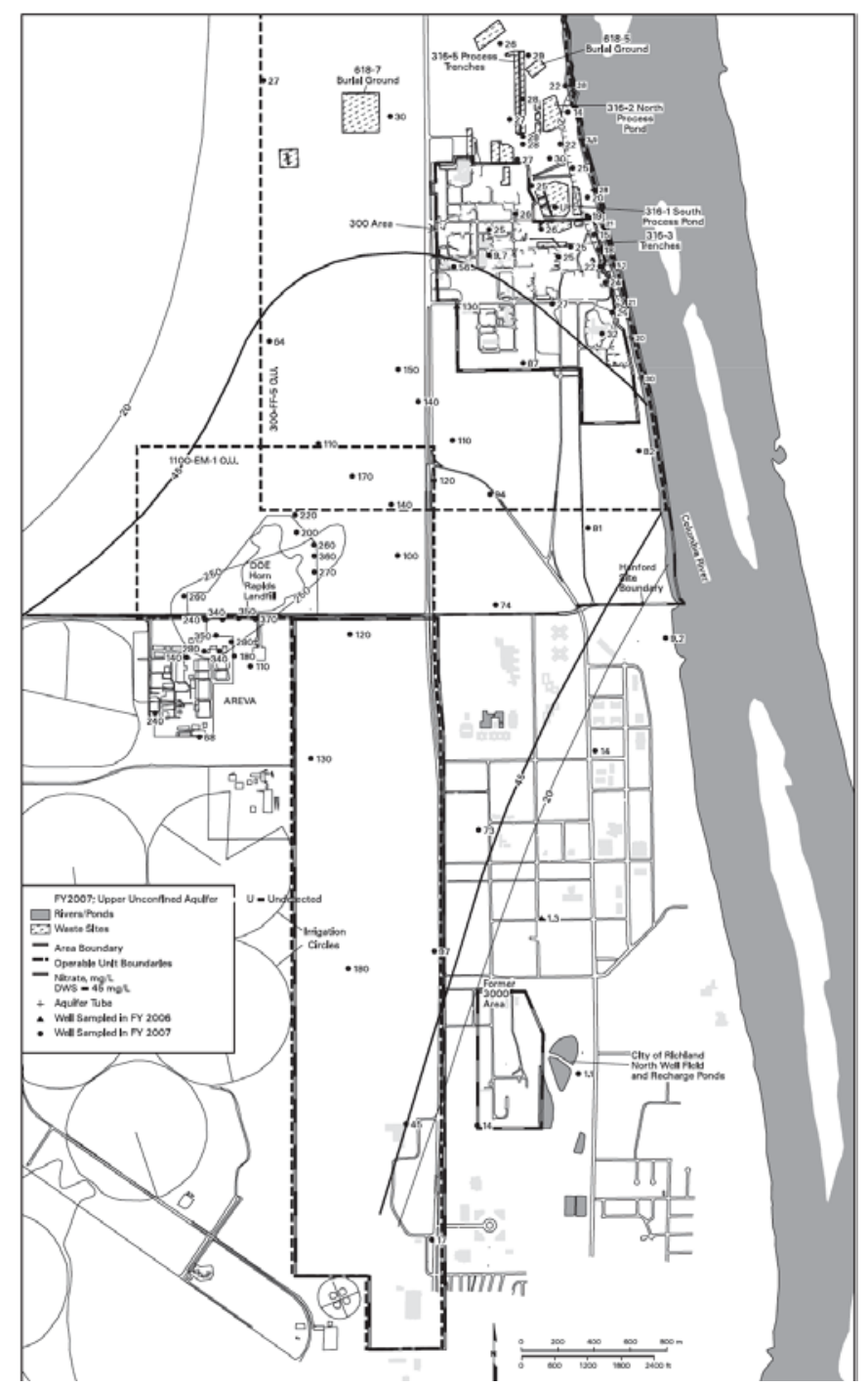

Figure A.4. Average Nitrate Concentrations in 1100-EM-1 OU Area, Upper Part of Unconfined Aquifer

\section{A.3.3 TCE}

TCE contamination is the most widespread of the volatile organic compounds in the area surrounding the BSF/CSF facility. It has been detected in the groundwater beneath DOE's inactive Horn Rapids Landfill and at AREVA wells at levels below the drinking water standard ( $\sim 5 \mu \mathrm{g} / \mathrm{L})$ (Figure A.5). The water samples from all the plume areas near DOE's Horn Rapids Landfill show that the concentration of the TCE remains below the drinking water standard in all monitoring wells. 


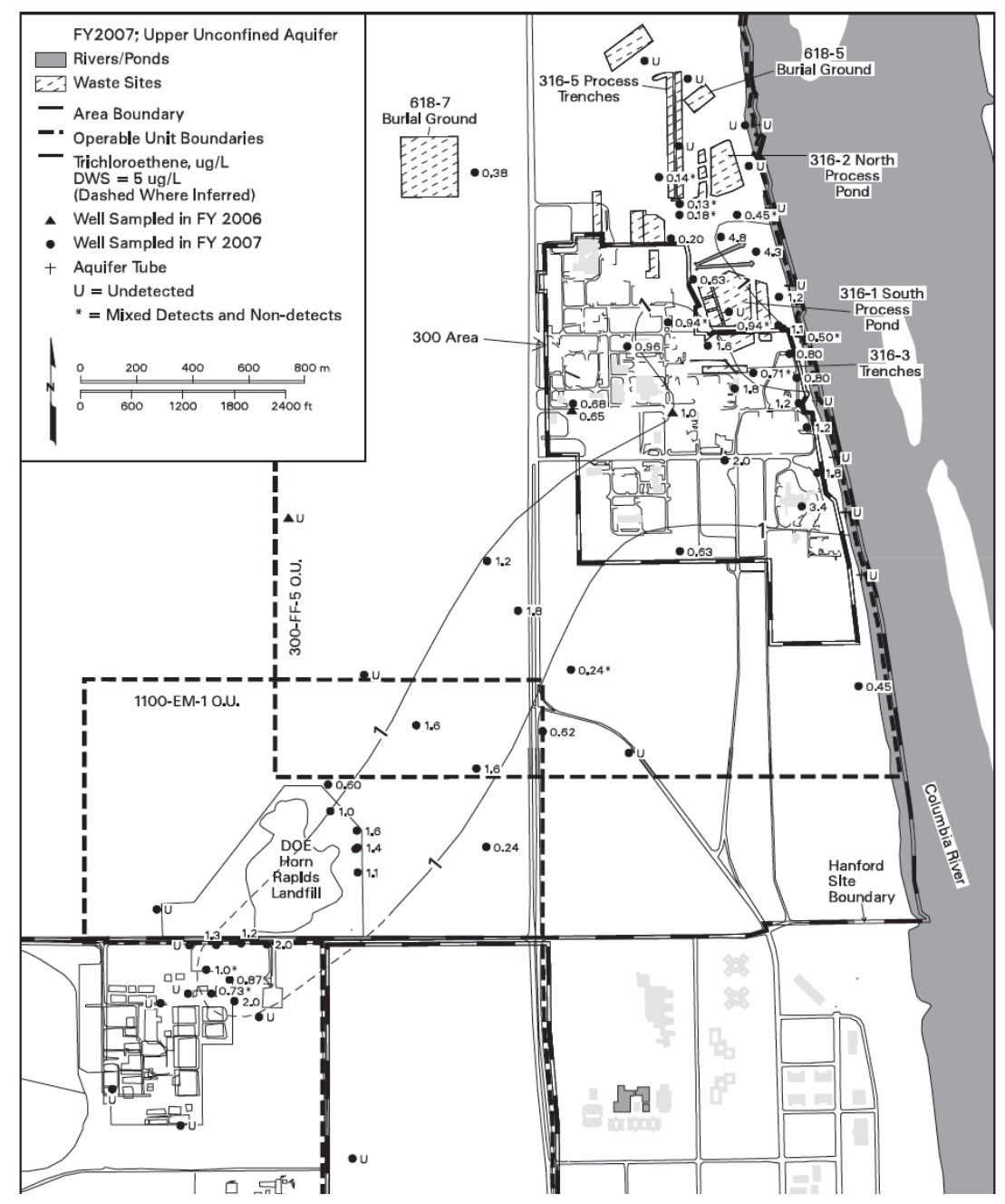

Figure A.5. Average TCE Concentrations in 300 and 1100-EM-1 OU Areas, Upper Part of Unconfined Aquifer

\section{A.4 Horn Rapids Sanitary Landfill}

The City of Richland monitors groundwater in the upper part of the unconfined aquifer on a quarterly basis for chemical constituents at the Horn Rapids Sanitary Landfill (formerly Richland Landfill), located $\sim 1 \mathrm{~km}$ south of the Hanford Site boundary. The analyses of water samples collected at wells just northeast of the city's sanitary landfill during FY07 revealed that the concentrations of chlorinated hydrocarbons (e.g., PCE, TCE, DCE) were below their respective minimum detection limits.

\section{A.5 The 200 Areas}

\section{A.5.1 Tritium}

The site-wide tritium plume originates in the 200 East Area in the vicinity of the plutonium-uranium extraction (PUREX) cribs (see Figure A.6) and extends from the southeast portion of the 200 East Area to 
the Columbia River. A second tritium plume is associated with the release of tritium from irradiated material in the 618-11 burial ground, which is located just to the west of the Energy Northwest complex and approximately $14 \mathrm{~km}$ northeast of the BSF/CSF facility. The highest concentrations of tritium (drinking water standard 20,000 pCi/L) are reported from locations near these cribs, up to 570,000 pCi/L in FY07. Due to radioactive decay and dispersion, the plume attenuates naturally as it spreads out to the east and southeast. Concentrations of tritium decrease in the far-field area, generally staying below $20,000 \mathrm{pCi} / \mathrm{L}$ and showing a steady decline with time in the region just north of the 300 Area located approximately $3 \mathrm{~km}$ north of the BSF/CSF facility.

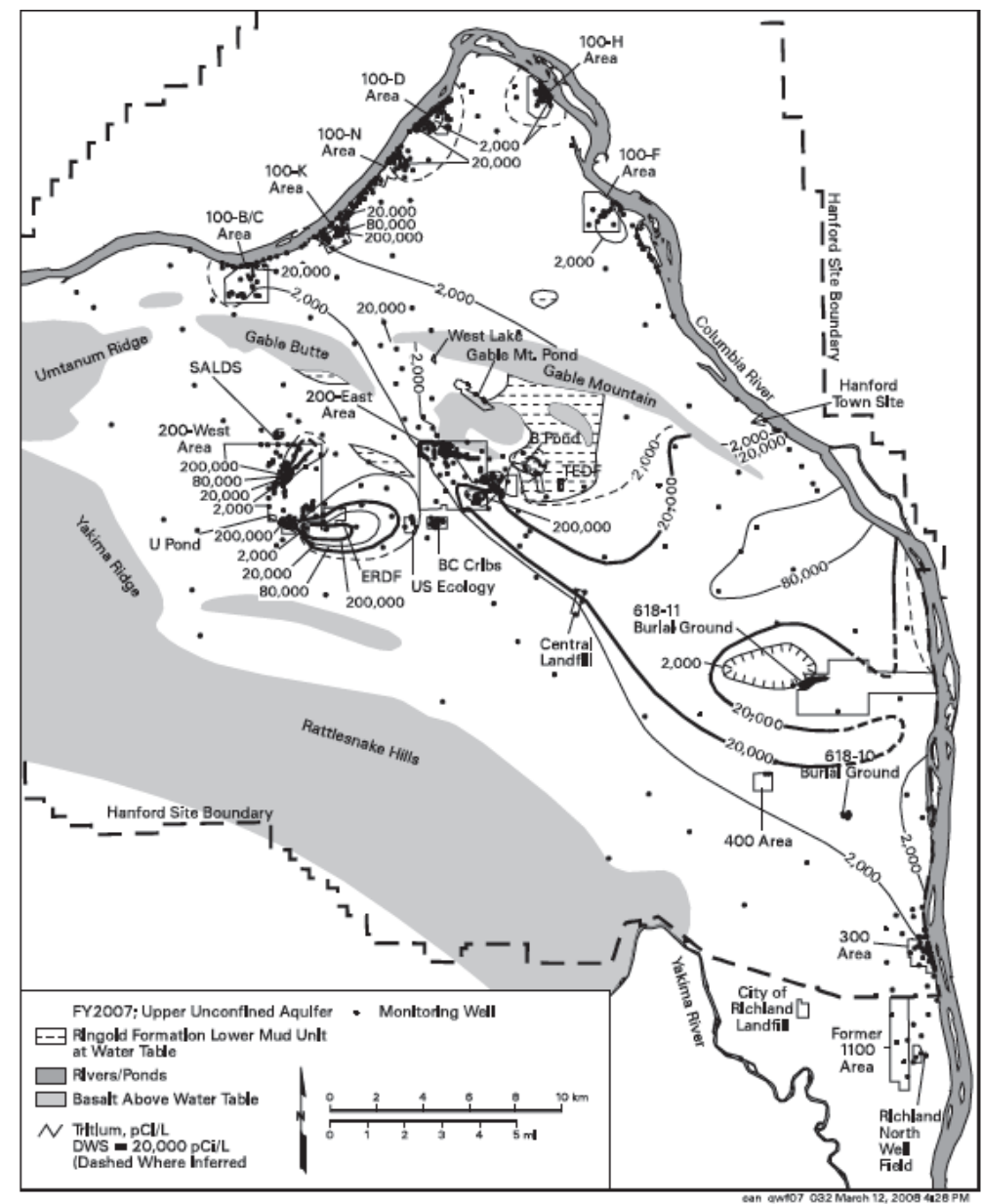

Figure A.6. Average FY07 Tritium Concentrations on the Hanford Site, Upper Part of Unconfined Aquifer

Low tritium concentrations in groundwater samples from the region south of the 300 Area show that tritium is not migrating to the city of Richland Well Field. The reported concentrations have remained below $300 \mathrm{pCi} / \mathrm{L}$ in the area west of the BSF/CSF facility (Figure A.7).

There are several factors limiting the migration of the tritium plume into the city of Richland Well Field, including 1) the general direction of the groundwater flow from west to east between the Yakima River and the Columbia River, 2) artificial recharge from agricultural irrigation in the west and central portions of the 1100-EM-1 OU area south of the Hanford Site contributes to the eastward and 
northeastward flow, and 3) groundwater mounding at the City of Richland's North Well Field from ponds used to recharge the well field.

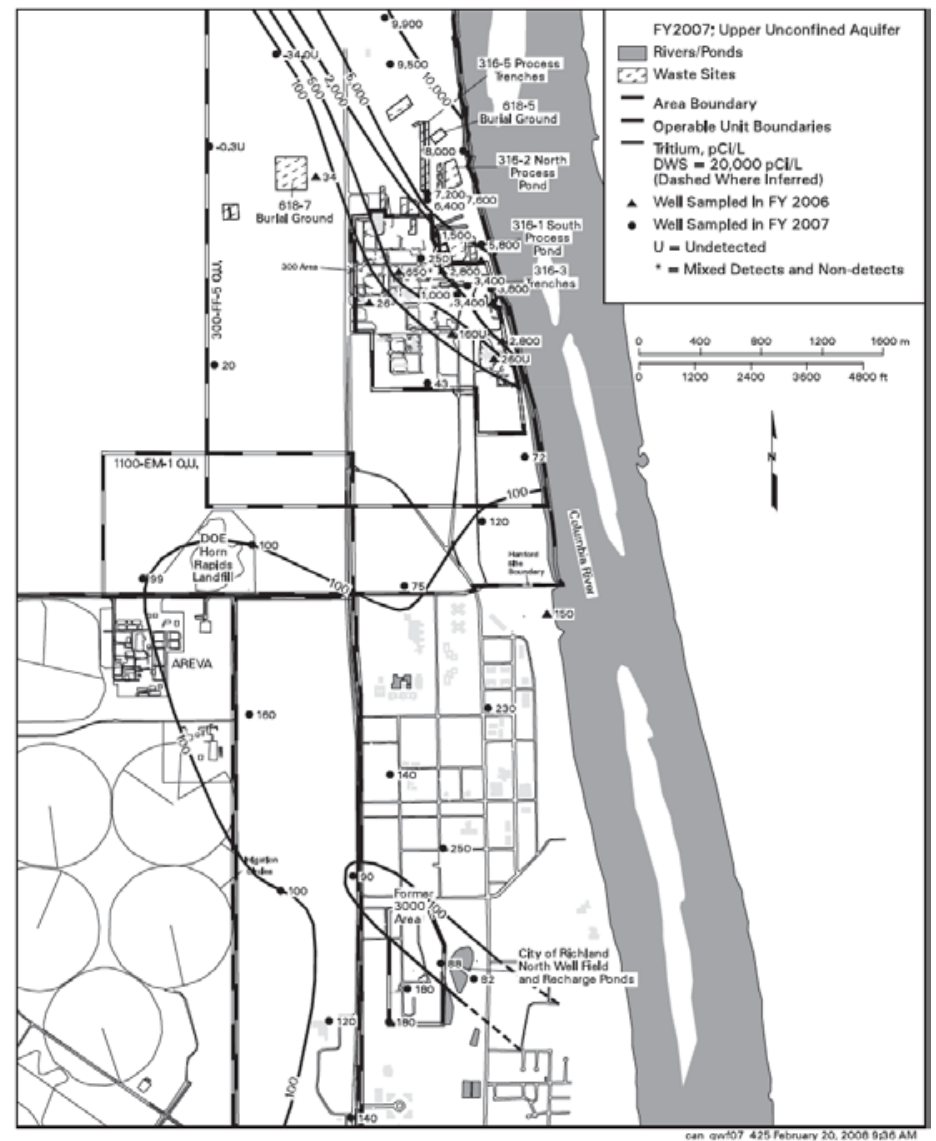

Figure A.7. Average Tritium Concentrations in 300 and 1100-EM-1 OU Areas, Upper Part of Unconfined Aquifer 

Appendix B

Geology 


\section{Appendix B: Geology}

\section{B.1 Ringold Formation}

The Ringold Formation is the oldest formal geologic unit (8.5 to 3.4 million years) penetrated during drilling at the BSF/CSF site and consists mostly of fluvial-lacustrine sediments overlying basalt flows of the Columbia River Basalt Group (CRBG). Locally, these sediments range in thickness from 155 to $180 \mathrm{ft}$; however, a direct analysis of the depth, thickness, and characteristics of the lower portion of the Ringold Formation was limited because of the relatively shallow depth of boreholes drilled at the BSF/CSF site. Regional interpretations for the lower stratigraphic units within the Ringold Formation are extrapolated from geologic logs for nearby wells (699-S28-E0, 699-S27-E9C, 699-S30-E14, and 699-S29-E16C) that extend to basalt bedrock (Figure B.1). Figure B.1 displays the location of geologic cross sections (Figure B.2 and Figure B.3) that were developed to illustrate the subsurface geology beneath the BSF/CSF site.

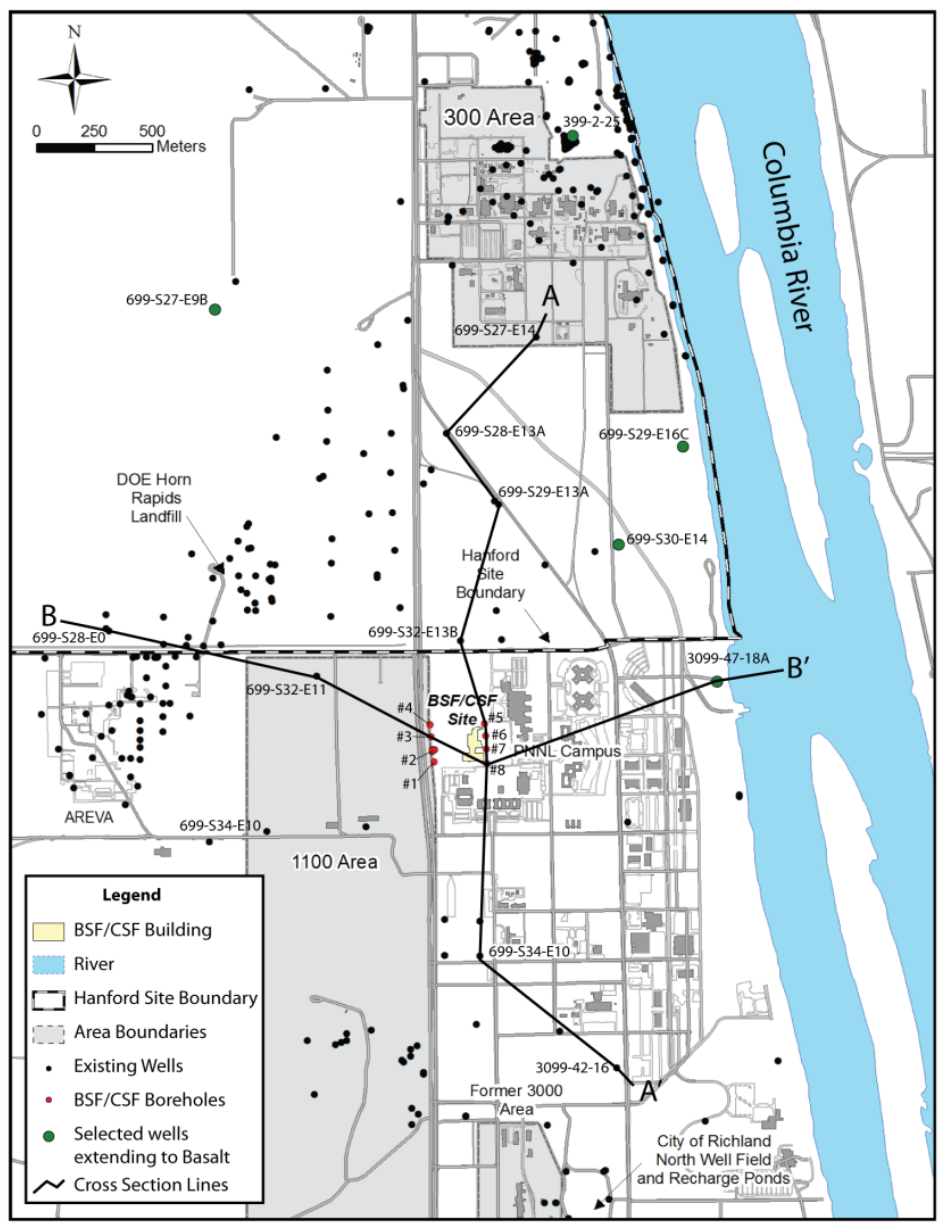

Figure B.1. Geologic Cross Section Locations 


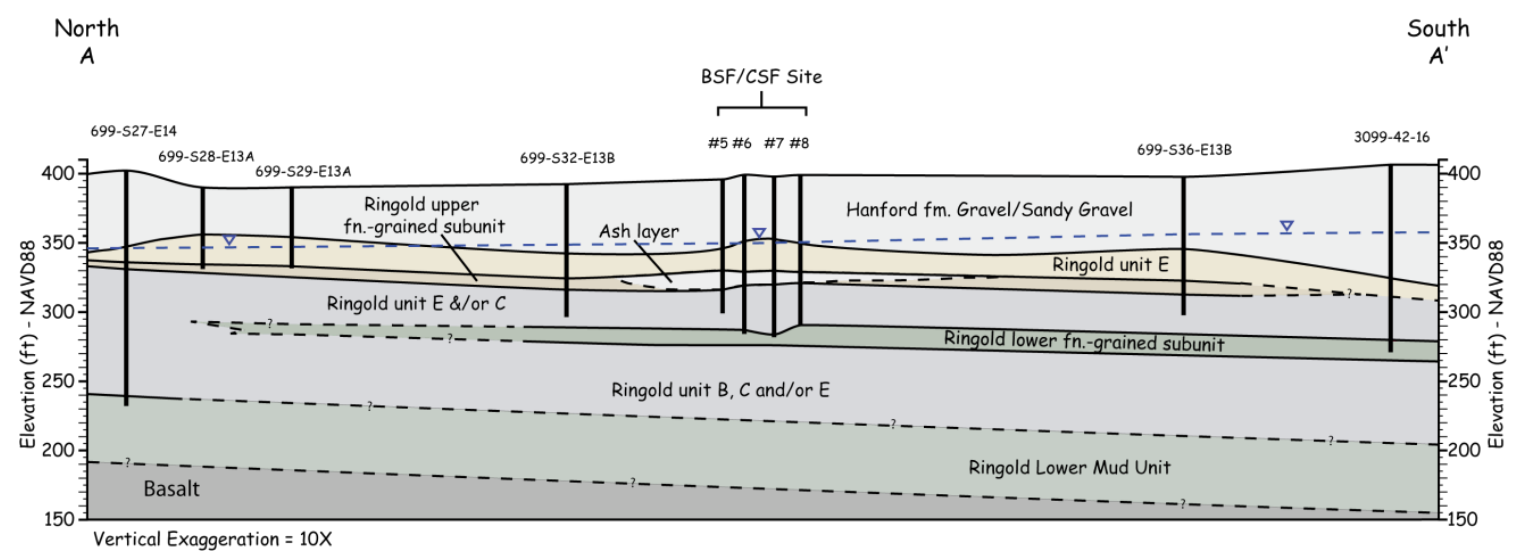

Figure B.2. Cross Section North to South (A-A') Across the BSF/CSF Construction Site

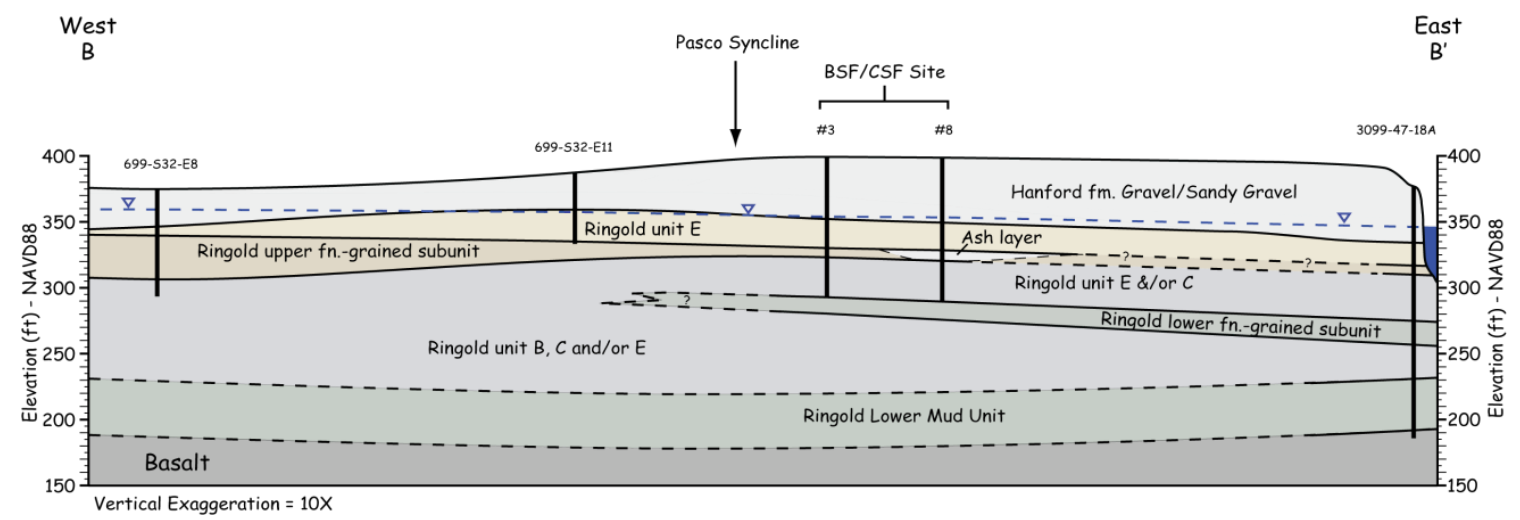

Figure B.3. Cross Section West to East (B-B') Across the BSF/CSF Construction Site

\section{B.1.1 Ringold Lower Mud Unit (RLM)}

Directly overlying the basalt surface are approximately 40 to $50 \mathrm{ft}$ of fine-grained sediments of the RLM (Figure B.3). These sediments are generally compact and cohesive, weakly laminated, tan-gray and gleyed green and blue clay, silt, and fine sand that represent lacustrine and overbank floodplain deposits (Bjornstad et al. 2009). Locally, a thin discontinuous water-bearing lens of calcium carbonate cemented sand (DOE/RL 1990) occurs as a thin basal layer of fine to coarse basaltic sand derived from erosion of the underlying basalt flows.

\section{B.1.2 Lower and Middle Ringold Gravel (units B, C, and/or E)}

Above the RLM are crudely stratified coarser grained gravel-dominated sediments with interbeds of fine- to medium-grained sand, clay, and siltstone. Within these sediments, two dominant fine-grained subunits (lower and upper) occur locally. These fine-grained subunits effectively partition the coarser gravel-dominated sediments into three separate packages, herein referred to as the lower, middle, and upper Ringold gravel-dominated units. None of the boreholes drilled at the BSF/CSF construction site penetrate the lower gravel-dominated unit. However, based on nearby geologic logs for wells that penetrate this unit, the lower and middle gravel-dominated sediments appear to share very similar characteristics. These semi-consolidated and weakly cemented sediments are typically a bimodal mixture 
of well-rounded, clast-supported pebbles and occasional cobbles compacted within a fine- to mediumgrained clean quartzitic and micaceous sand (Figure B.4). Variable amounts of dark grey silt and clay may occur within the matrix. Pebbles and cobbles are generally mafic-dominated with up to $60 \%$ dark clasts such as basalt, andesite, volcanic porphyry, and some dark metamorphics. Light-colored clasts are mostly quartzite, granite, and gneiss (Campbell 1983). Weathering rinds are common, especially among basalt clasts. Several minor interbeds of gravelly sand, sand, clay, and siltstone are commonly intercalated with gravels, occurring as discontinuous lenses.
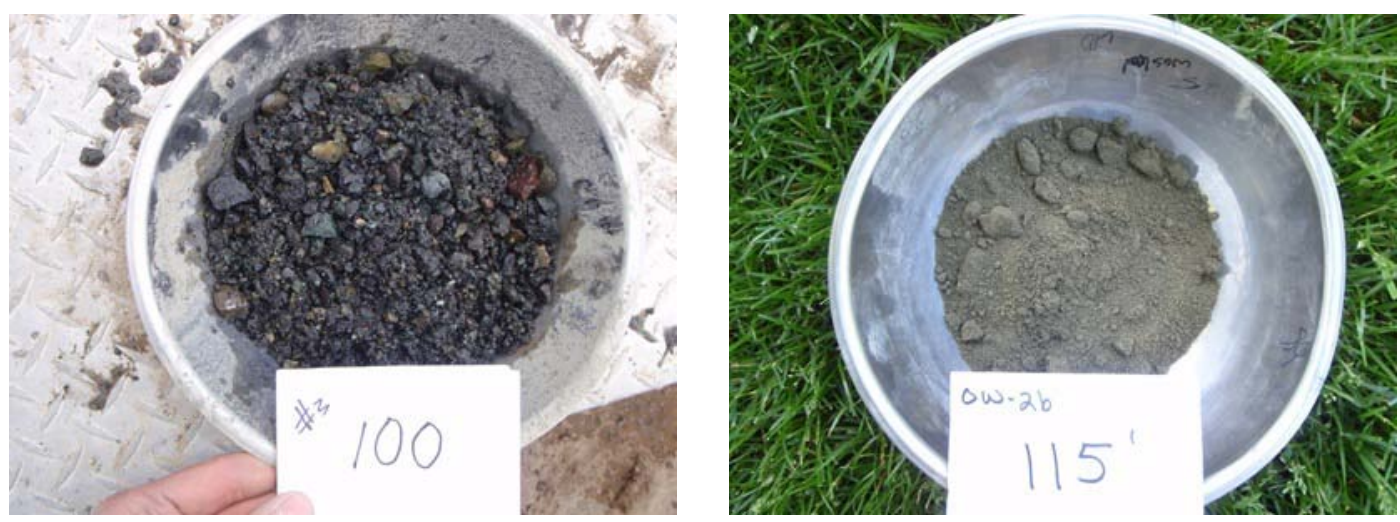

Figure B.4. Sediment Samples Collected from $100 \mathrm{ft}$ bgs at Borehole \#3 and $115 \mathrm{ft}$ bgs at Borehole \#2B. Coarse sandy gravel (left) is the dominant facies of the middle gravel sequence between the upper and lower fine-grained subunits. The lower fine-grained subunit (right) generally consists of compacted silty sand to sandy silt and clay (photograph taken of dried sample).

\section{B.1.3 Lower Fine-Grained Subunit}

Beneath the BSF/CSF construction site, a lower fine-grained subunit occurs between the lower and middle Ringold gravel-dominated units as a massive, cohesive, and compact layer of gray to blue-green fine-grained silty sand to sandy silt and clay (Figure B.4). This lower fine-grained facies was encountered in 10 of 11 boreholes drilled at the BSF/CSF construction site. The shallowest borehole, pilot hole \#5, was not deepened beyond the projected depth of this unit and thus was not encountered during drilling. At 2B, located on the west side of the construction site, the lower fine-grained subunit was fully penetrated, exposing a thickness of approximately $12 \mathrm{ft}$ of cohesive and compact, well-sorted very fine silty sand (Figure B.4) grading up into sandy silt. The lateral extent and variability of this unit is uncertain due to a limited number of deep boreholes providing direct evidence for a wide regional presence. No existing boreholes located within a few miles directly west of the BSF/CSF site were identified as having been deep enough to encounter this unit. East of the BSF/CSF site, five boreholes extend to, or fully penetrate, this unit, three of which (699-S29-E16C, 3099-47-18A, and 3099-45-18B) are located within $100 \mathrm{~m}$ of the Columbia River shoreline. Unit thickness ranges from $12 \mathrm{ft}$ at $2 \mathrm{~B}$ to $20 \mathrm{ft}$ near the river shoreline at well 3099-47-18A (Figure B.3).

\section{B.1.4 Upper Fine-Grained Subunit}

Overlying the middle gravel sequence is another fine-grained subunit that generally occurs as brown to olive-brown clay, silt, sandy silt, silty sand, sand, and gravelly sand. These sediments occur beneath 
the BSF/CSF site as a 5- to 14-ft-thick layer of compacted, slightly silty sand to gravelly sand (Figure B.5). Regionally, based on multiple surrounding wells that fully penetrate this horizon, texture and thickness vary from east to west, becoming coarser grained as the unit thins to the east. The spatial variation in grain size and texture is likely a result of lateral grading during deposition within a fluvial over-bank or crevasse-splay setting. Regionally, the unit ranges in thickness from $33 \mathrm{ft}$ in well 699-S32E8, located just north of the DOE Horn Rapids Landfill, to approximately $5 \mathrm{ft}$ at the BSF/CSF construction site (Figure B.3). This wide range in thickness is likely a result of both the undulating surface geometry of the underlying sediments and local surface erosion before the overlying Ringold Formation was deposited.

Beneath the east side of the BSF/CSF construction site, the upper fine-grained sediments noted above are not present and appear to have been completely eroded away, as they were not observed in boreholes 5, 6, 7, and 8. In these boreholes, a distinct volcanic ash layer unconformably overlies the middle Ringold gravel unit (Figure B.5) and occurs as a 6- to 14-ft layer of white to light brownish gray glassy angular to subangular very fine silty sand to sandy silt-sized grains. The geometry and lateral extent of the ash layer beneath the BSF/CSF site and toward the Columbia River is uncertain. Northwest of the BSF/CSF site, this ash layer is up to $23 \mathrm{ft}$ thick and has been well documented in DOE/RL (1990, 1992a, 1992b) as disconformably overlying and being laterally continuous with the Ringold upper fine-grained subunit. No ash of a comparable thickness or of a similar stratigraphic horizon has been reported from the Ringold Formation elsewhere within the Pasco Basin. The lateral extent of the ash appears to be limited to local erosional depressions within the upper fine-grained facies, and the top of the ash layer occurs at the same elevation, indicating that it is laterally continuous with the upper fine-grained subunit. This ash layer has been interpreted to be originally from a relatively small airfall deposit that was subsequently reworked by a fluvial system and preserved as isolated remnants within depositional lows on top of an erosional surface (DOE/RL 1990, 1992a, 1992b).
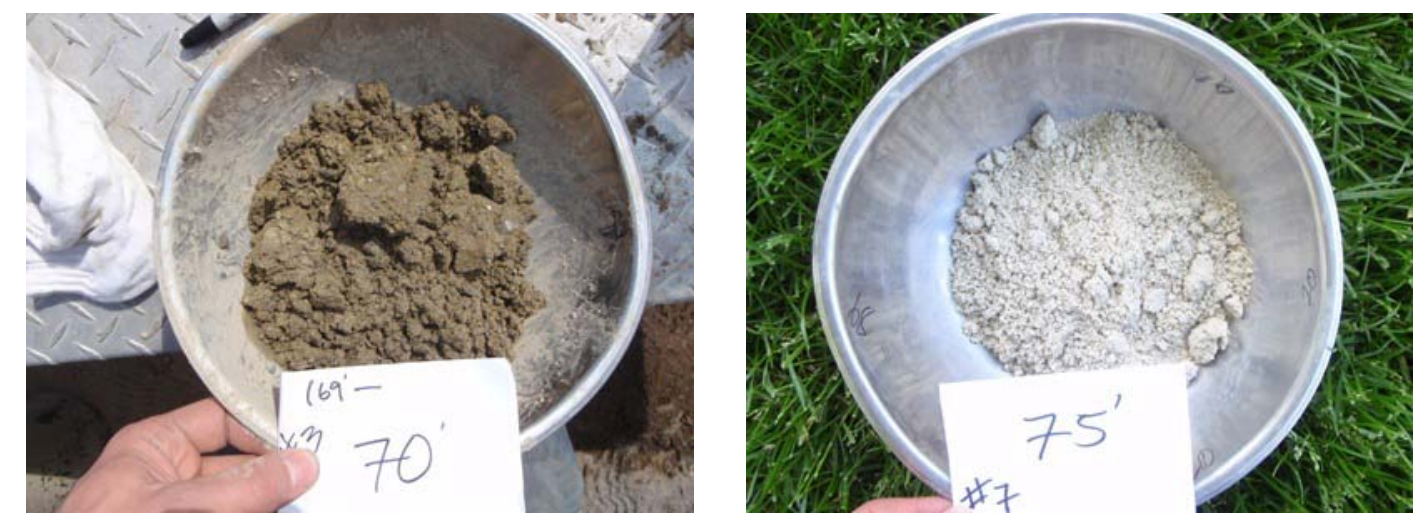

Figure B.5. Sediment Sample Collected from 69 to $70 \mathrm{ft}$ bgs Within the Upper Fine-Grained Subunit in Borehole \#3 (Left) and Sediment Sample Collected from 75 ft bgs Within the Volcanic Ash Layer Encountered in Borehole \#7

\section{B.1.5 Upper Ringold Gravel (Unit E)}

Overlying the upper fine-grained subunit is 10 to $20 \mathrm{ft}$ of coarse-grained gravel-dominated sediments of Ringold Unit E (Lindsey 1995). These clast-supported sediments are generally highly oxidized and weathered and mostly consist of well-rounded and polished heterolithic pebbles and occasional cobbles, 
compacted in a brown to olive-brown medium quartzitic and micaceous sand matrix with variable amounts of silt (Figure B.6). The upper 5 to $10 \mathrm{ft}$ of this unit is often calcareous and contains up to $80 \%$ gravel clasts. Sand concentration generally increases with depth, and sediments often grade into gravelly sand near the contact with the upper fine-grained subunit below. In contrast with the lower and middle gravel-dominated facies, the upper Ringold gravels generally contain a higher concentration of lightcolored clasts (granitics, quartzite, gneiss, and other volcanics) with lesser amounts of darker clasts (basalt, andesite, porphyry, and metasediments).
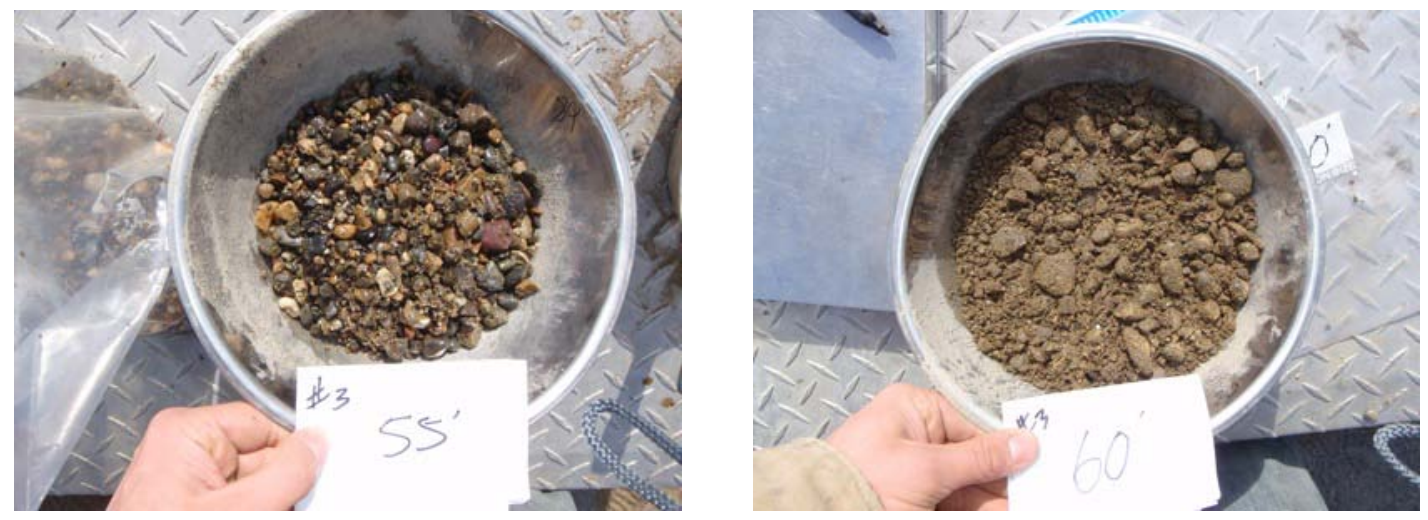

Figure B.6. Sediment Samples Collected from $55 \mathrm{Ft}$ and $60 \mathrm{ft}$ bgs at Borehole \#3. Coarse gravel (left) and sandy gravel (right) are the dominant facies associated with the upper Ringold Unit E gravel beneath the BSF/CSF site.

\section{B.1.6 Hanford Formation}

Overlying the Ringold Formation beneath the BSF/CSF site is up to $55 \mathrm{ft}$ of unconsolidated heterogeneous sand and gravel (Figure B.7) of the Hanford formation that occur as a poorly sorted mixture of boulders, cobbles, pebbles, and sand derived from Pleistocene-age glaciofluvial flooding. Coarse gravel and sandy gravel are the dominant facies of the Hanford formation beneath the BSF/CSF site; however, discontinuous lenses of medium to very coarse sand and gravelly sand are common. Sand grains and gravel clasts are generally unweathered and subangular to subrounded with a high concentration of basalt rock fragments (up to 80\%). However, the concentration of basalt clasts generally decreases with depth, especially near the contact with the underlying Ringold Formation, likely as a result of erosion and mixing of the Ringold Formation during the initial onslaught of cataclysmic flooding. 

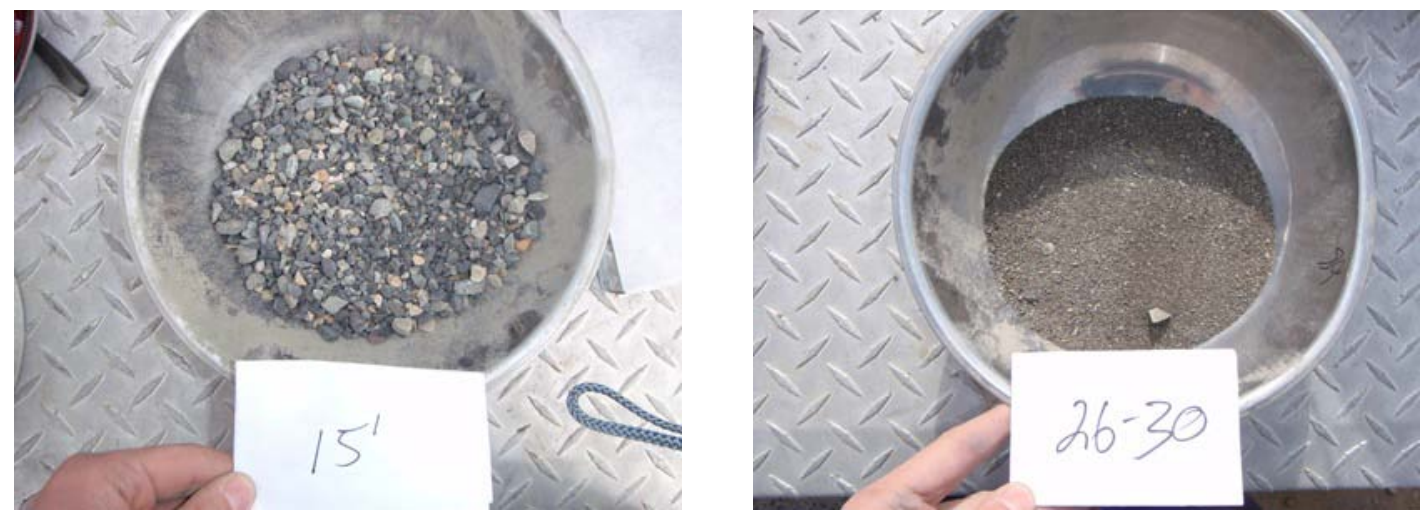

Figure B.7. Sediment Samples Collected from $15 \mathrm{Ft}$ and 26 to $30 \mathrm{ft}$ bgs at Borehole \#3. Coarse gravel (left) and sandy gravel are the dominant facies within the Hanford Formation beneath the BSF/CSF site. Minor interbeds of sand (right) and gravelly sand are both common.

\section{B.1.7 Recent Surficial Deposits}

Recent (Holocene) surficial deposits locally form a thin unit overlying the Hanford formation near the BSF/CSF site. These deposits have been widely disturbed at the BSF/CSF site as a result of ongoing construction activities and range in thickness from zero to a few feet. These sediments are derived from a mixture of eolian sand, silt, and decomposed vegetation that have undergone pedogenic alteration, forming the modern soil horizon. 
Appendix C

As -Builts 


\section{Appendix C: As-Builts}

\section{BSF/CSF Production Well \#1}

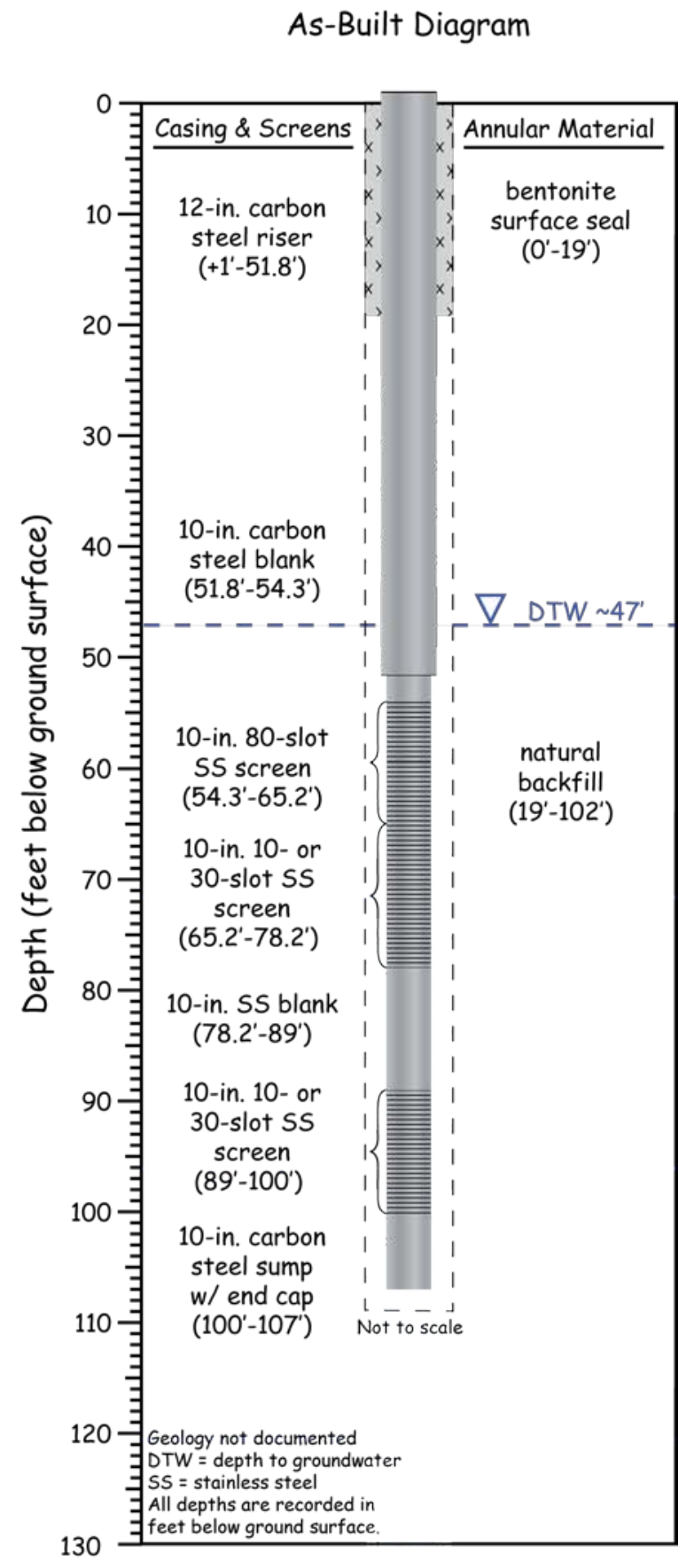

Figure C.1. Summary of Borehole Log and As-Built Diagram for Production Well \#1 


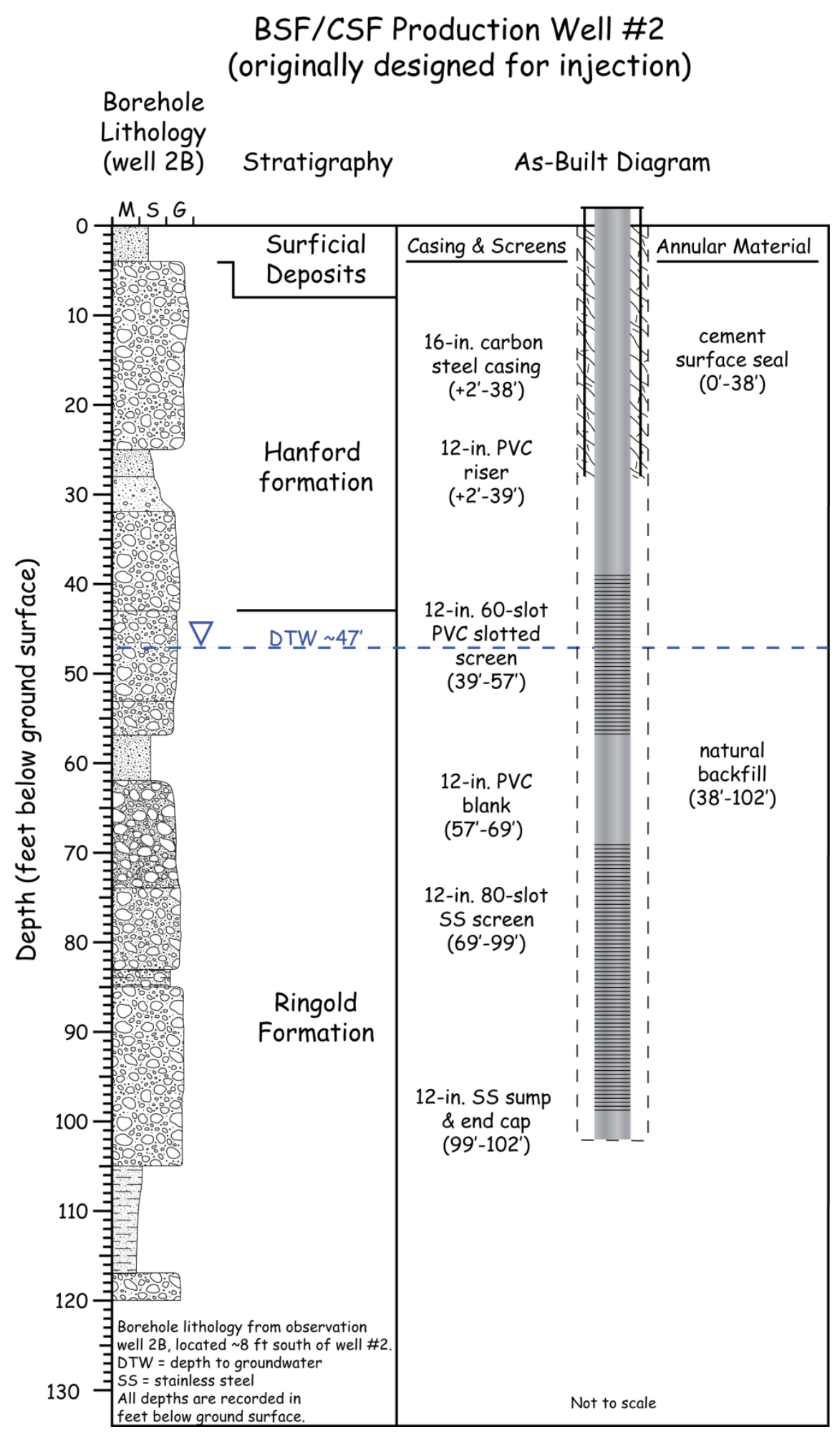

Figure C.2. Summary of Borehole Log and As-Built Diagram for Production Well \#2 


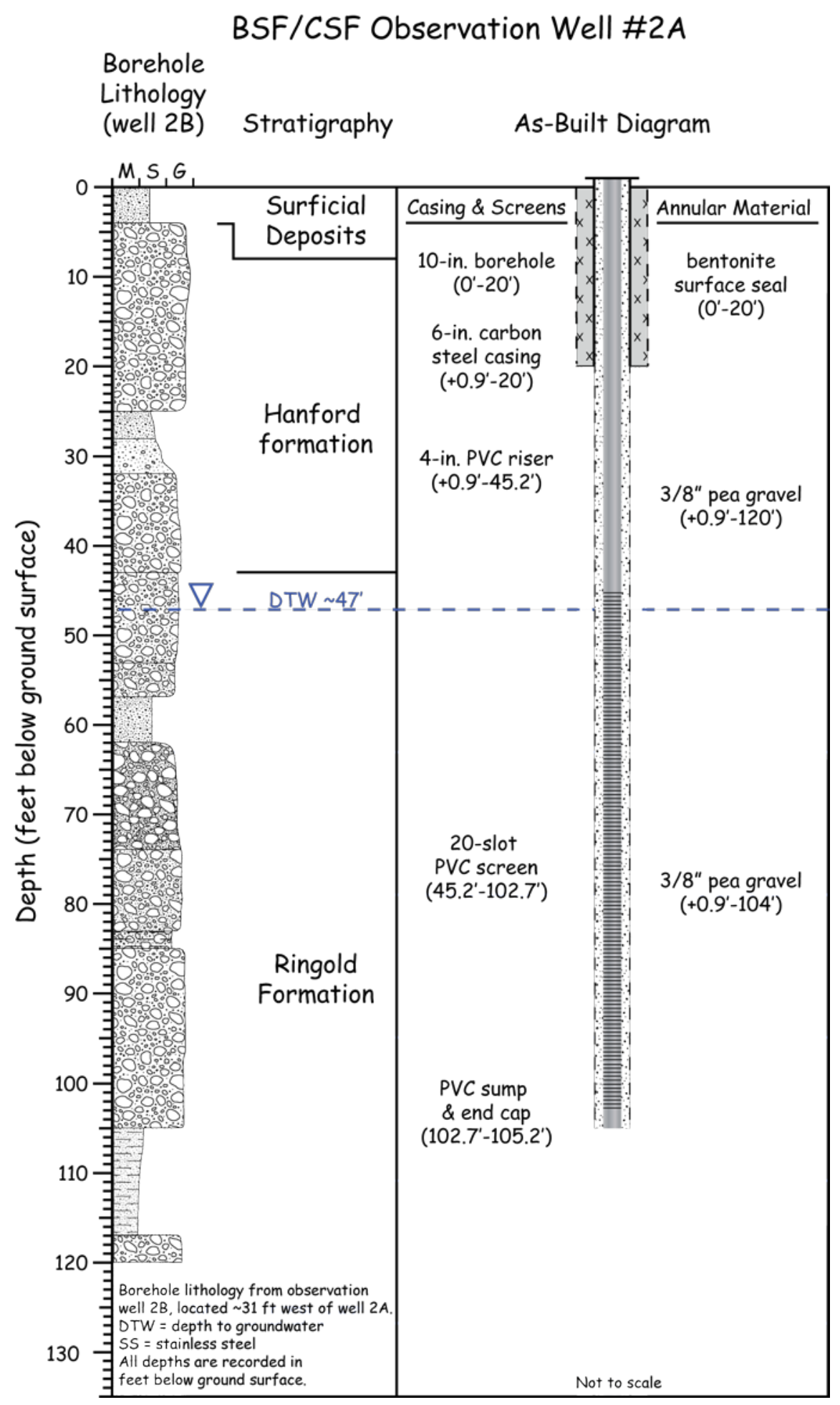

Figure C.3. Summary of Borehole Log and As-Built Diagram for Observation Well \#2a 


\section{BSF/CSF Observation Well \#2B}

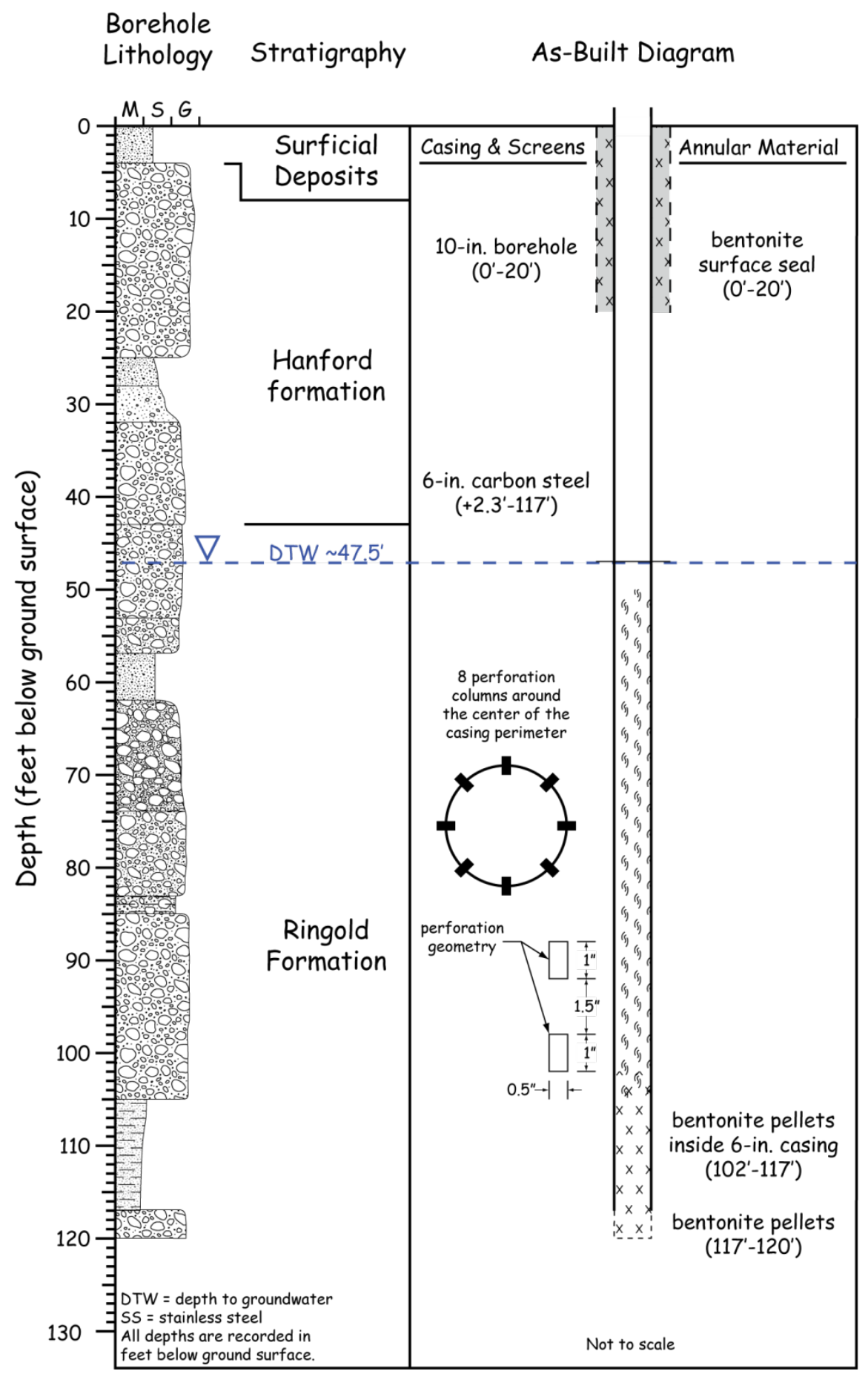

Figure C.4. Summary of Borehole Log and As-Built Diagram for Observation Well \#2b 


\section{BSF/CSF Observation Well \#2C}

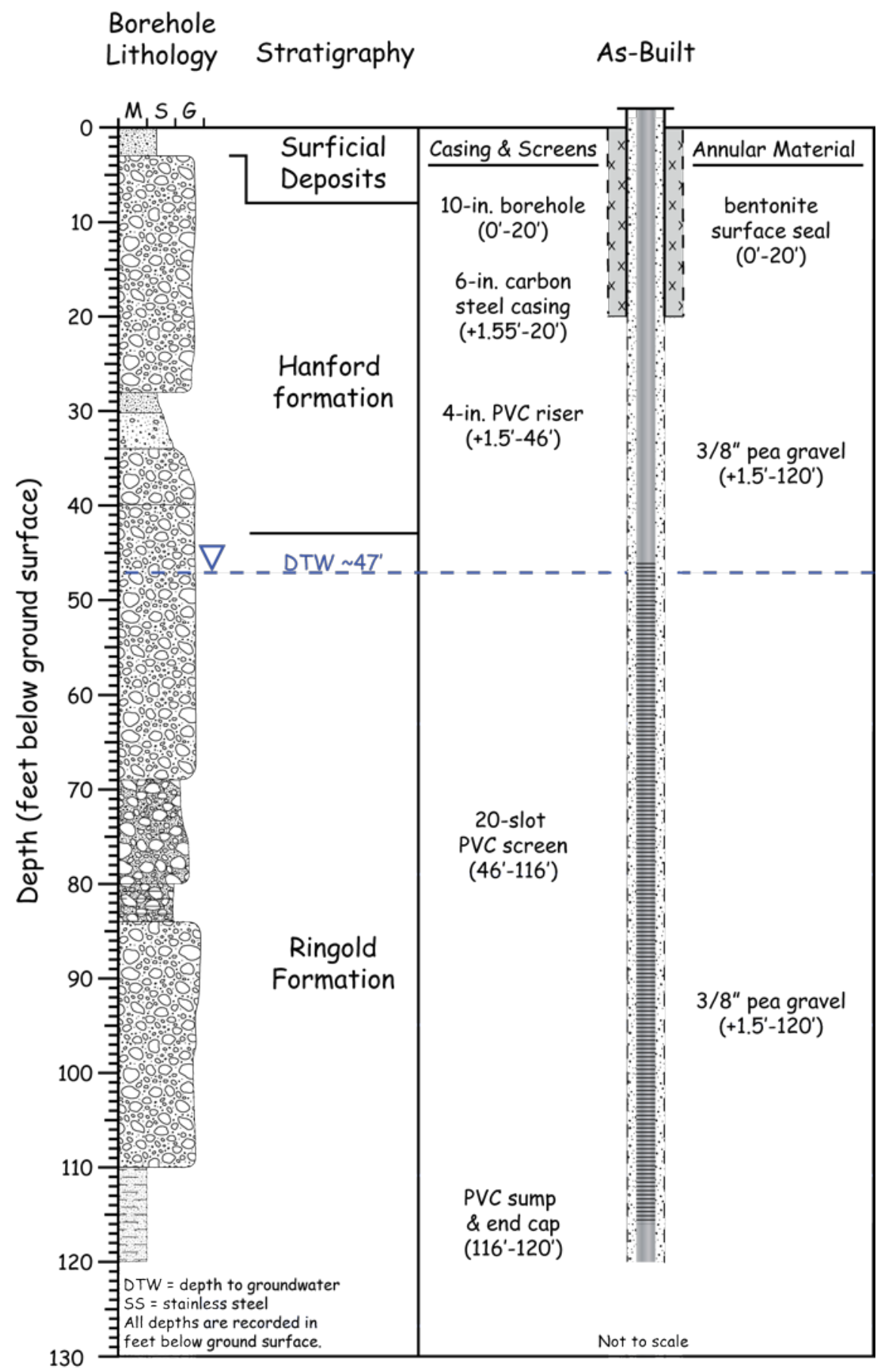

Figure C.5. Summary of Borehole Log and As-Built Diagram for Observation Well \#2c 


\section{BSF/CSF Production Well \#3}

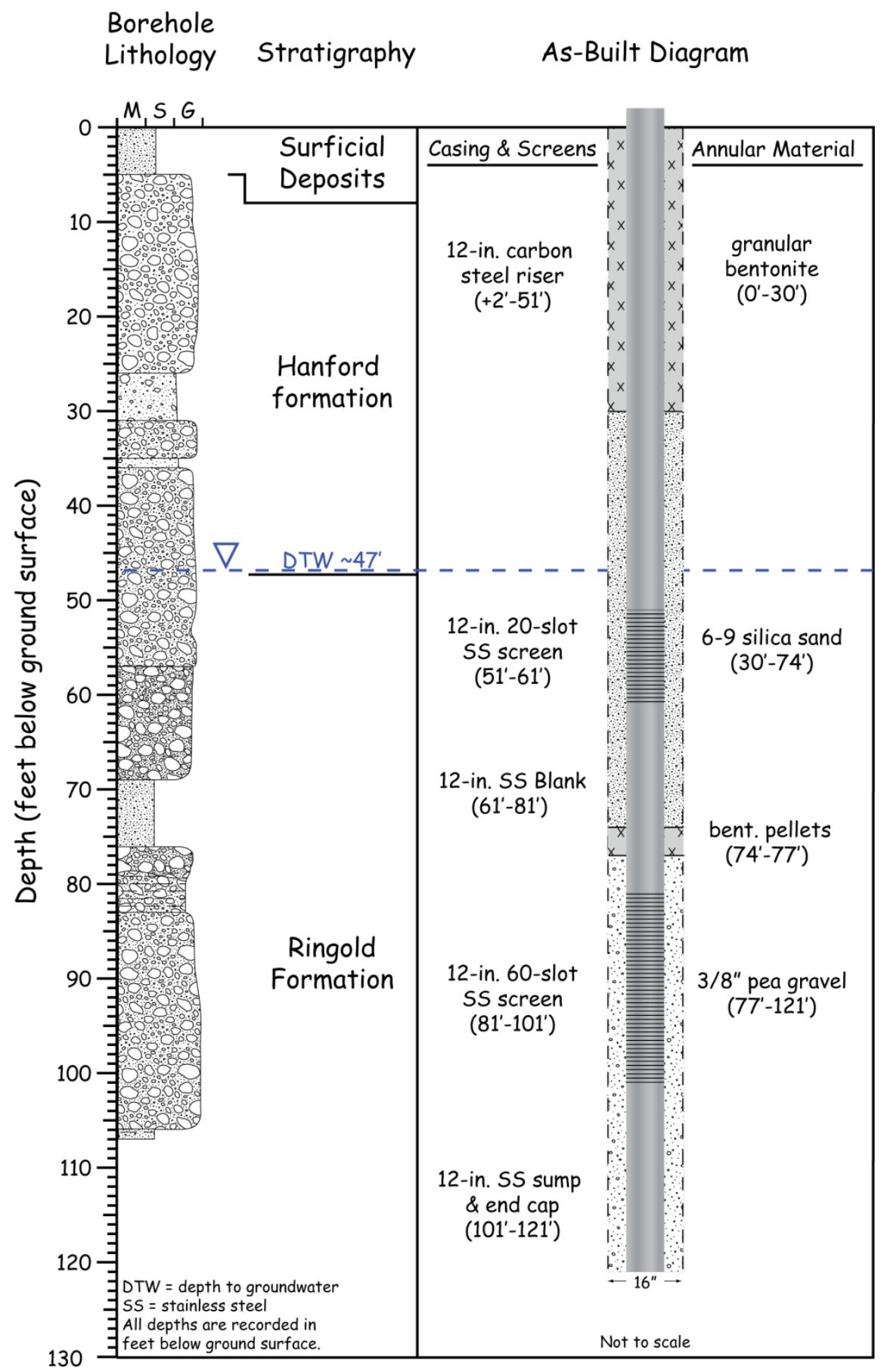

Figure C.6. Summary of Borehole Log and As-Built Diagram for Production Well \#3 


\section{BSF/CSF Production Well \#4}

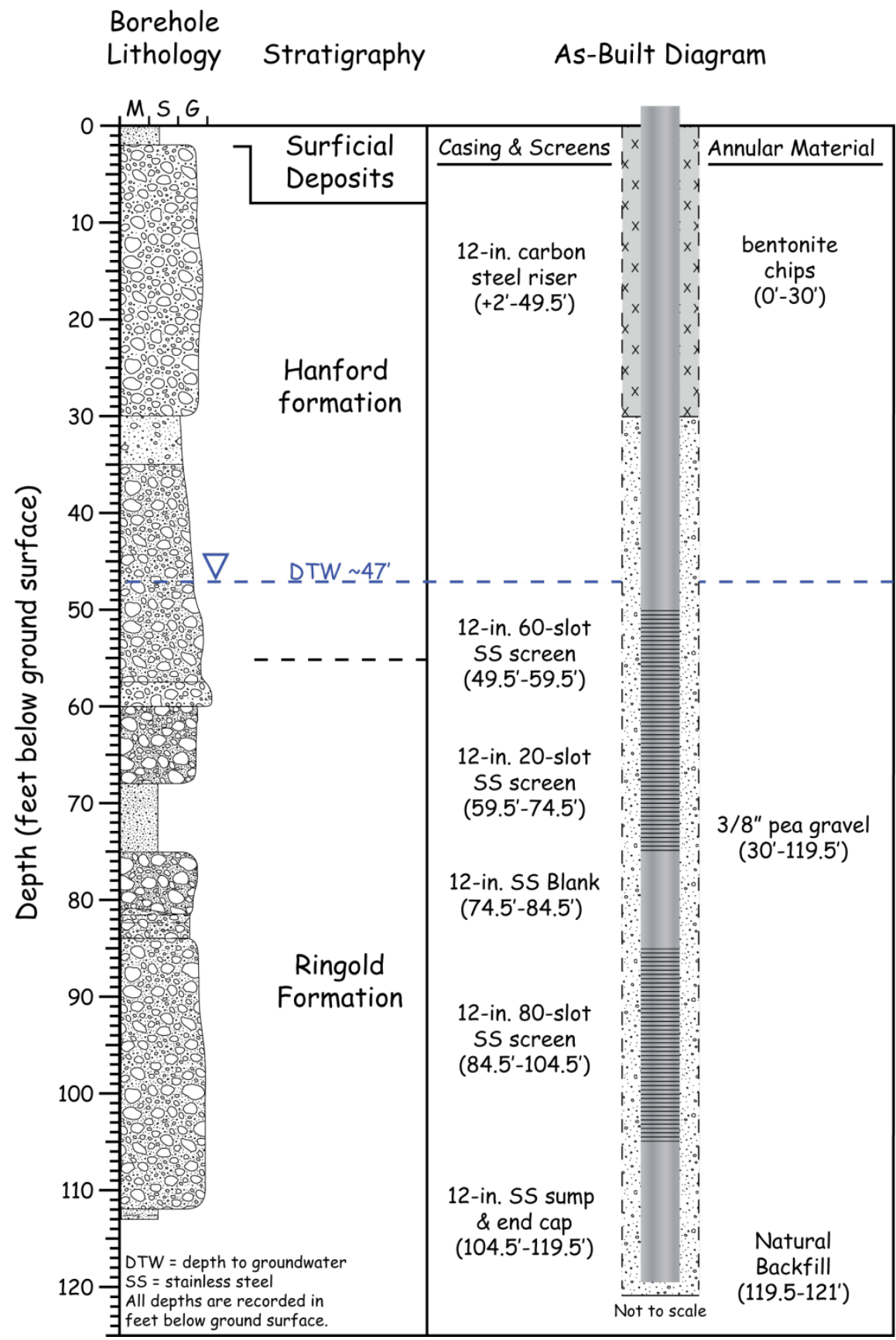

Figure C.7. Summary of Borehole Log and As-Built Diagram for Production Well \#4 


\section{BSF/CSF Injection Well \#5}

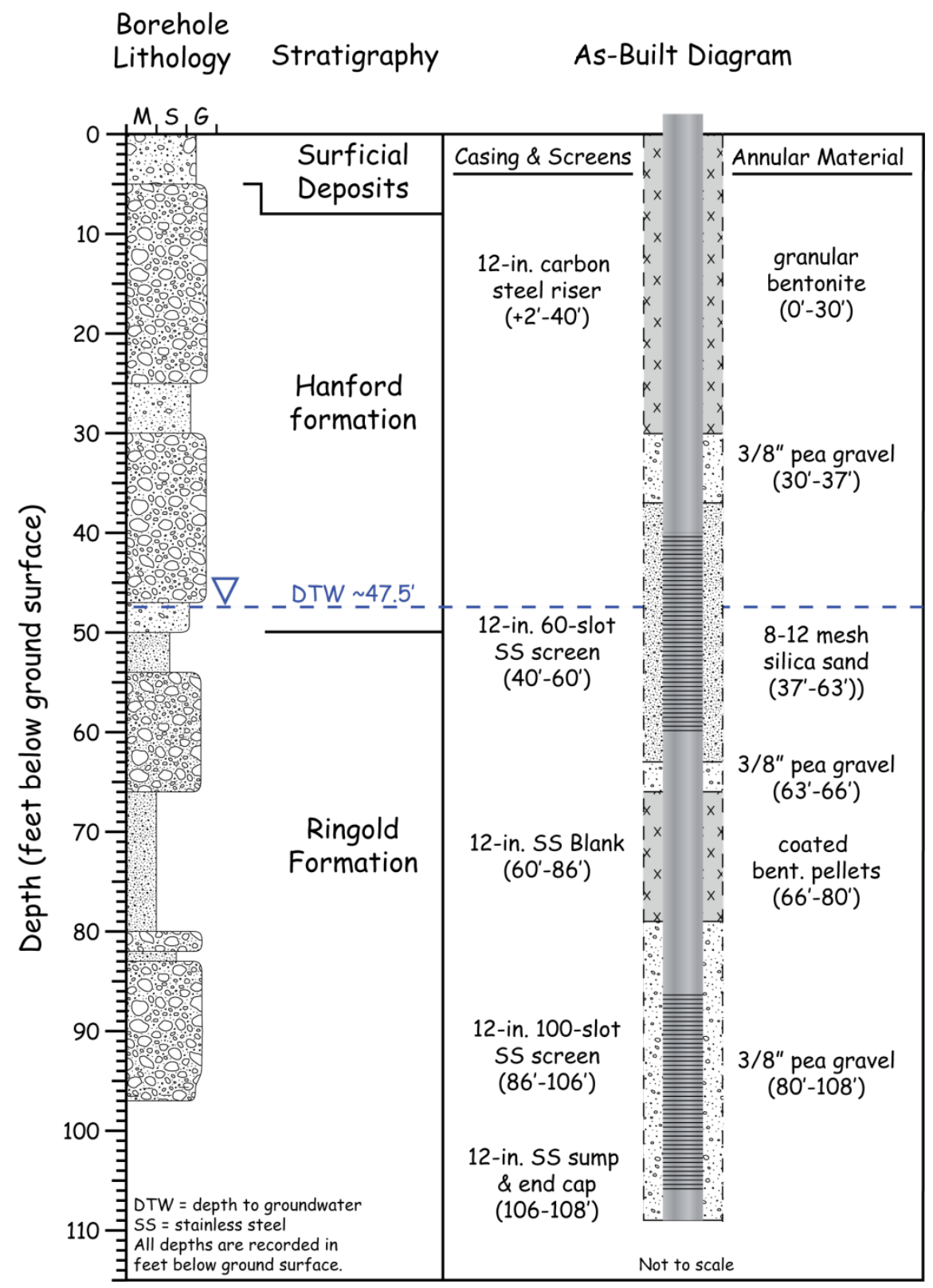

Figure C.8. Summary of Borehole Log and As-Built Diagram for Injection Well \#5 


\section{BSF/CSF Injection Well \#6 \\ (originally designed for extraction)}

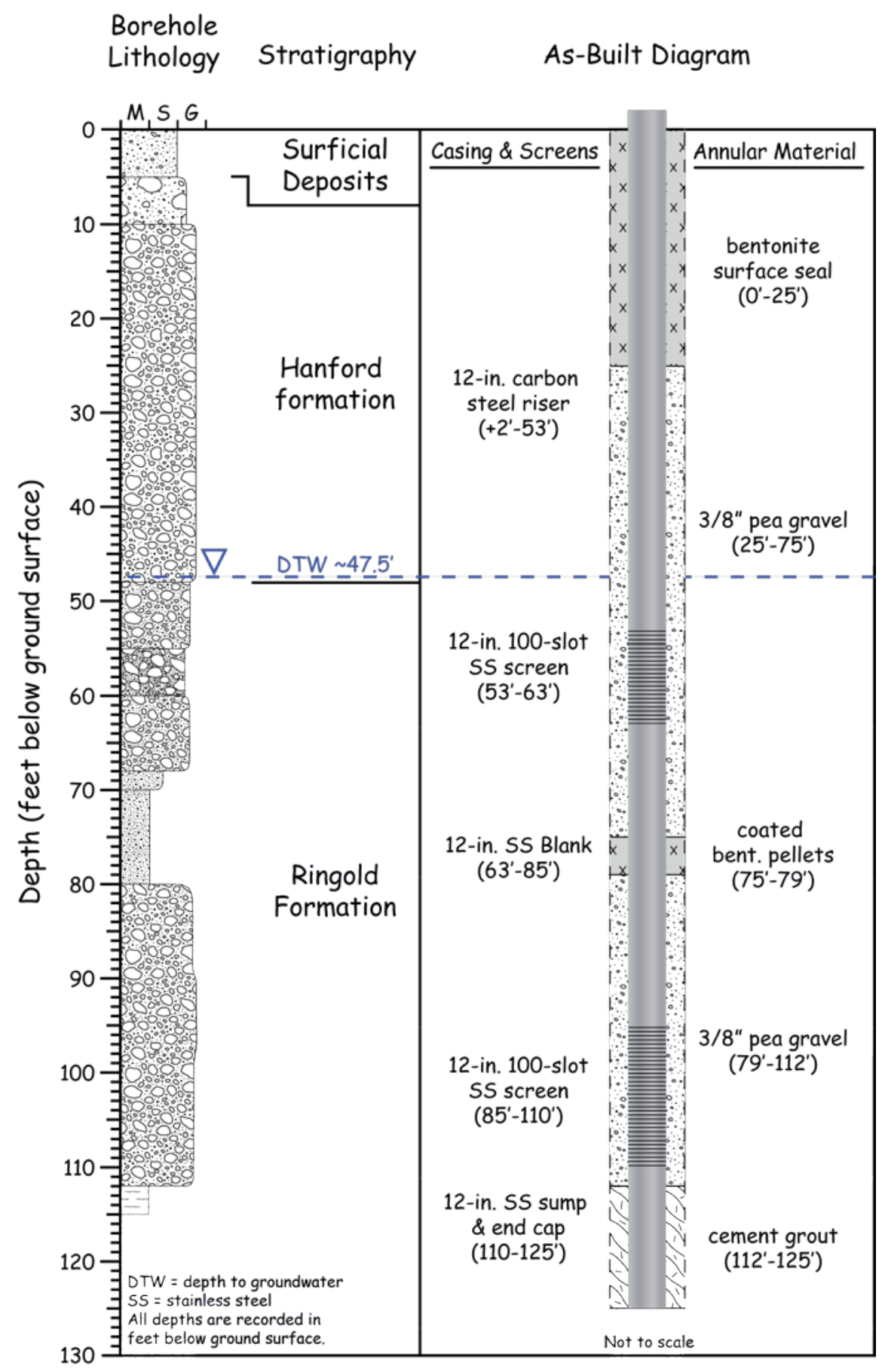

Figure C.9. Summary of Borehole Log and As-Built Diagram for Injection Well \#6 


\section{BSF/CSF Injection Well \#7}

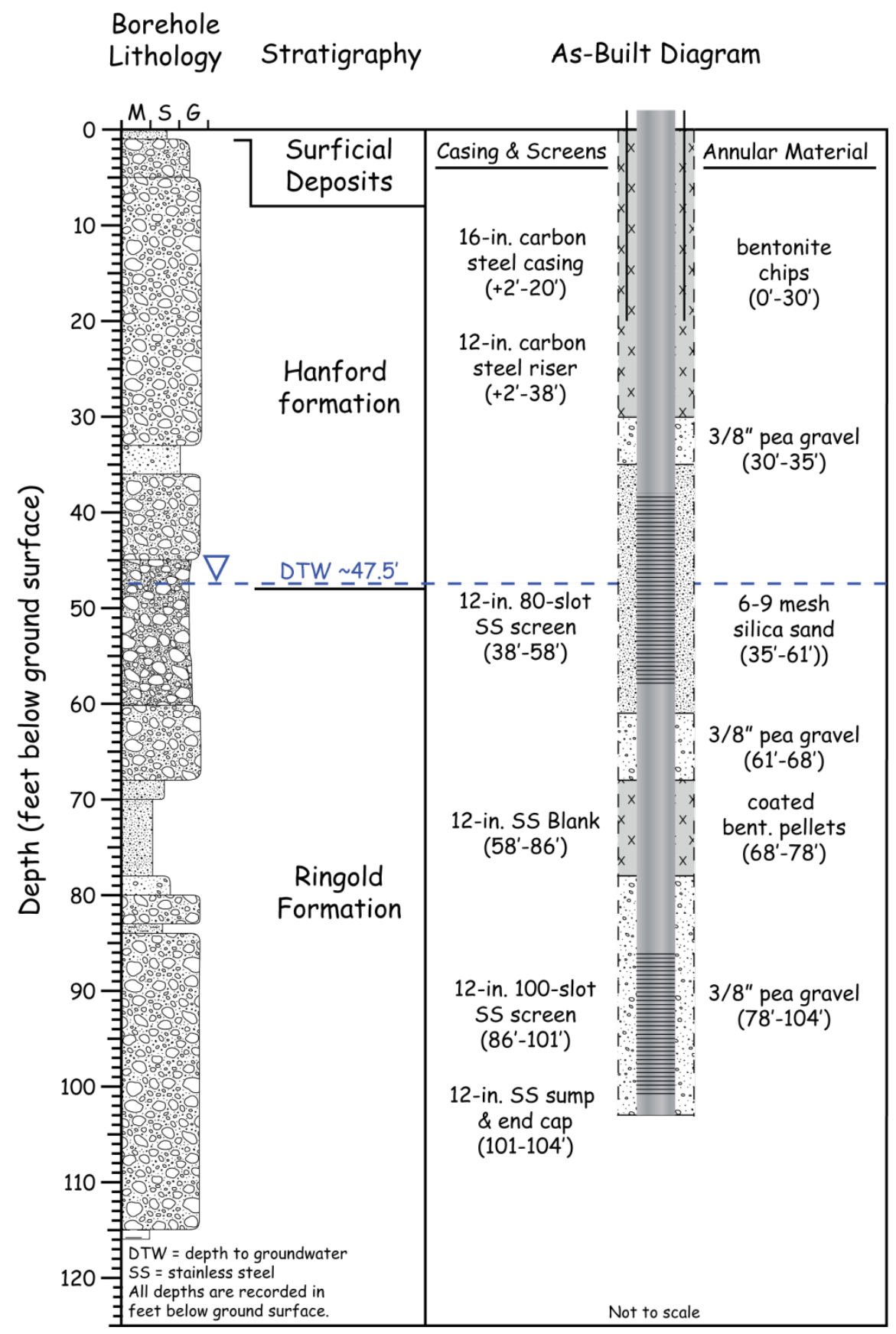

Figure C.10. Summary of Borehole Log and As-Built Diagram for Injection Well \#7 


\section{BSF/CSF Injection Well \#8}

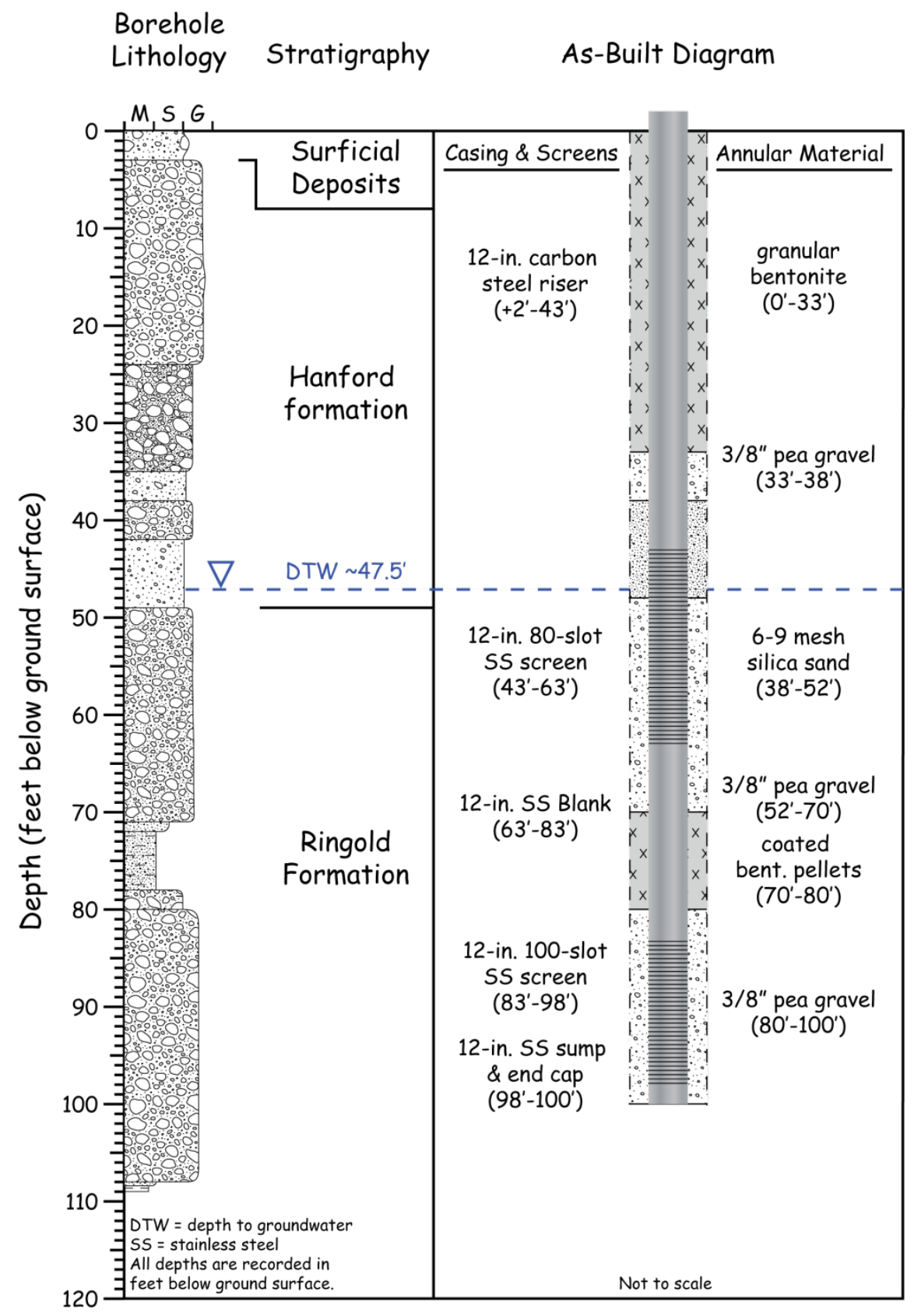

Figure C.11. Summary of Borehole Log and As-Built Diagram for Injection Well \#8 

Appendix D

Hydraulic Characterization 


\section{Appendix D: Hydraulic Characterization}

\section{D.1 Published Hydraulic Properties}

A literature review was conducted to survey hydraulic properties of the Ringold and Hanford Formations. Most published estimates of saturated hydraulic conductivity are from the 300 Area, which range from 2 to 15,200 m/d (Figure D.1) for the Upper Ringold and Hanford Formations. At the lower range of estimates are the laboratory tests conducted on split-tube samples (Swanson 1992). Laboratorymeasured vertical hydraulic conductivities were 0.15 and $0.20 \mathrm{~m} / \mathrm{d}$, and porosity was measured at 0.18 and 0.19. In that same study, constant discharge aquifer tests of two wells completed in the Hanford formation yielded 37 and $49 \mathrm{~m} / \mathrm{d}$ for the horizontal saturated conductivity; 2.1 and $5.5 \mathrm{~m} / \mathrm{d}$ for vertical hydraulic conductivity, 0.37 and 0.02 for specific yield; and 0.013 and 0.005 for storativity.

The most recent aquifer testing near the study area was depth-discrete slug testing on three 300 Area wells (Williams et al. 2007; see Figure D.1). Two of the wells tested the Hanford formation, and the resulting estimates of K were "> $100 \mathrm{~m} / \mathrm{d}$ ” (399-1-23) and “ $\geq 2000 \mathrm{~m} / \mathrm{d}$ ” (399-3-20). Estimates of the underlying Ringold Formation ranged from 0.04 to $41 \mathrm{~m} / \mathrm{d}$.

The study by Liikala (1994) is the only available one specific to the area south of the 300 Area. Liikala compiled K estimates for the 300 Area, 1100 Area (Richland Well Field, 2.5 miles south of PNNL), 3000 Area (1 mile south of PNNL), and 600 Area wells in the region (600 Area includes all of the Hanford Site not occupied by the 100, 200, 300, and 400 Areas). K estimates in the 1100 and 3000 Areas ranged from 0.6 to $945 \mathrm{~m} / \mathrm{d}$ (Figure D.2). 


\begin{tabular}{|c|c|c|c|c|}
\hline Geologic Unit & $\begin{array}{l}\text { Ksat } \\
(\mathrm{m} / \mathrm{d})\end{array}$ & Location & Reference & Source of data \\
\hline Hanford & 37 & 699-S27-E9 & \multirow{4}{*}{$\begin{array}{l}\text { Swanson } 1992 \\
\text { (WHC-SD-EN-TI-052) }\end{array}$} & \multirow[t]{4}{*}{ Constant discharge test } \\
\hline Hanford & 49 & 699-S22-E9 & & \\
\hline Hanford, Kv & 2.1 & 699-S27-E9 & & \\
\hline Hanford, Kv & 5.5 & 699-S22-E9 & & \\
\hline Hanford & 3350 & $399-1-13$ & \multirow{10}{*}{$\begin{array}{l}\text { Schalla et al. } 1988 \\
\text { (PNL-6716) }\end{array}$} & \multirow[t]{10}{*}{ Constant discharge test } \\
\hline Hanford/Ringold & 1.83 & $399-1-9$ & & \\
\hline Upper Ringold & 15200 & $399-1-18 A$ & & \\
\hline Upper Ringold & 152 & $399-1-16 A$ & & \\
\hline Ringold & 0.58 & 399-1-18B & & \\
\hline Ringold & 3.66 & 399-1-17B & & \\
\hline Ringold & 79.2 & $399-1-17 C$ & & \\
\hline Ringold & 2.74 & $399-1-16 C$ & & \\
\hline Lower Ringold & 0.61 & 399-1-16D & & \\
\hline Lower Ringold & 1.83 & $399-1-18 C$ & & \\
\hline \multirow[t]{3}{*}{ Hanford } & $>100$ & $399-1-23$ & \multirow{5}{*}{$\begin{array}{l}\text { Williams et al. } 2007 \\
\text { (PNNL-16435) }\end{array}$} & \multirow[t]{5}{*}{ Slug test } \\
\hline & $\geq 2000$ & 399-3-19 & & \\
\hline & $\geq 2000$ & $399-3-20$ & & \\
\hline Ringold Upper Mud & $0.04-0.36$ & & & \\
\hline Ringold & $0.7-41$ & & & \\
\hline Hanford & 1500 & & \multirow{2}{*}{$\begin{array}{l}\text { Meyer et al. } 2007 \text { (PNNL-16396), } \\
\text { Waichler and Yabusaki } 2005\end{array}$} & \multirow{2}{*}{$\begin{array}{l}\text { review of published and } \\
\text { unpublished data }\end{array}$} \\
\hline Hanford, Kv & 150 & & & \\
\hline Hanford & $6.06-20195$ & & $\begin{array}{l}\text { Thorne et al. } 2006 \\
\text { (PNNL-14753) }\end{array}$ & $\begin{array}{l}\text { Sitewide Groundwater } \\
\text { Model inverse calibration }\end{array}$ \\
\hline Hanford U1 & 6000 & & Peterson et al. 2008 & input for 300 Area \\
\hline Ringold fine U4 & 1 & & (PNNL-17034) & STOMP model \\
\hline Ringold E gravels U5 & 40 & & & \\
\hline \multicolumn{5}{|c|}{ Specific Yield Estimates } \\
\hline Hanford & 0.37 & 699-S27-E9X & Swanson 1992 & \multirow[t]{2}{*}{ Constant discharge } \\
\hline Hanford & 0.02 & 699-S22-E9X & (WHC-SD-EN-TI-052) & \\
\hline Hanford & $0.1-0.3$ & & Wurstner et al. 1995 (PNNL- & literature review \\
\hline Ringold U5 & $0.05-0.2$ & & 10886), & \\
\hline Hanford & 0.1 & & $\begin{array}{l}\text { Thorne et al. } 2006 \\
\text { (PNNL-14753) }\end{array}$ & $\begin{array}{l}\text { Sitewide Groundwater } \\
\text { Model inverse calibration }\end{array}$ \\
\hline
\end{tabular}

Figure D.1. Hydraulic Conductivity Estimates for Hanford and Ringold Formations in the 300 Area (from Williams et al. 2007)

Unconfined aquifers: undifferentiated Ringold Fm. and Hanford formation

Area

1100 and 3000 Areas

600 Area

300 Area

1100-EM-1 OU

Siemens Power Corp.
Ksat (m/day)

3-945

27

$0.6-15,240$

$0.6-43$

158
Source

Bierschenk 1959

$"$

Bierschenk 1959, Schalla et al. 1988, Tillson et al. 1969

DOE 1990b

J-U-B Engineers Inc. 1982

Figure D.2. Hydraulic Conductivity Estimates for Region Between Yakima and Columbia Rivers (from Liikala 1994, PNL-10094, Table 3.5, p. 3.25) 
Two recent 300 Area modeling studies considered the reported values and used $1500 \mathrm{~m} / \mathrm{d}$ for horizontal hydraulic conductivity and $150 \mathrm{~m} / \mathrm{d}$ for vertical hydraulic conductivity (Meyer at al. 2007, Yabusaki et al. 2008, Waichler and Yabusaki 2005). Another recent modeling study used a value of 6000 $\mathrm{m} / \mathrm{d}$ (Peterson et al. 2008). Estimates of $\mathrm{K}$ from inverse modeling of the entire Hanford Site range up to 20,000 m/d (Thorne et al. 2006). More information about current estimates of hydraulic conductivity for geologic units in the 300 Area can be found in Figure D.3, a table reprinted from Meyer et al. (2007). Vertical hydraulic conductivity has generally been assumed to be 0.01 to 0.1 times the horizontal conductivity in Hanford Site groundwater modeling (Meyer at al. 2007).

\begin{tabular}{|c|c|c|c|c|}
\hline & & $\begin{array}{l}\text { Estimated Range } \\
\text { for Hanford Site } \\
\text { Based on Pump }\end{array}$ & & \\
\hline & $\begin{array}{l}\text { Current Average } \\
\text { Estimates for } 300\end{array}$ & $\begin{array}{l}\text { Tests, Slug Tests, } \\
\text { and Some Lab }\end{array}$ & $\begin{array}{l}\text { Inverse Model } \\
\text { Estimates for }\end{array}$ & $\begin{array}{l}\text { Inverse Model } \\
\text { Estimates for }\end{array}$ \\
\hline Hydrogeologic Unit & Area & Tests (1) & Hanford Site (2) & Hanford Site (3) \\
\hline U1 - Hanford & 1500 & $1-1 \mathrm{e} 6$ & $2-30,000$ & $192-37,100$ \\
\hline U5 - Ringold sand/gravel & 150 & $0.1-200$ & $0.1-4,000$ & 3 \\
\hline U6 - Ringold overbank & 0.01 & $0.0003-0.09$ & $0.01-0.1$ & \\
\hline U7 - Ringold sand/gravel & 43 & $0.1-200$ & $0.008-90$ & \\
\hline U8 - Ringold lacustrine & 5.00E-05 & $0.0003-0.09$ & & 0.0002 \\
\hline Basalt & 5.00E-05 & & & \\
\hline
\end{tabular}

(1) Based on interpretation of measurements column 2, Wurstner et al. 1995 (PNNL-10886); Thorne and Newcomer 1992 (PNL-8337)

(2) Cole et al. 2001 (PNNL-13447)

(3) Vermeul et al. 2003 (PNNL-14398)

Figure D.3. Hydraulic Conductivity Estimates for Hanford and Ringold Formations (from Meyer et al. 2007, PNNL-16396, Table 4.1, p. 39)

Swanson (1992, Table 1) estimated specific yield estimates at 0.02 to 0.37 . Inverse calibration of the Sitewide Groundwater Model led to an estimate of Sy $=0.1$ for the Hanford Formation (Thorne et al. 2006). Figure D.4 contains the hydraulic property values used in 300 Area simulations by Yabusaki et al. (2008) and Waichler and Yabusaki (2005). 
Table 3.1. Key material properties for STOMP simulations. Vertical hydraulic conductivities were set to $10 \%$ of the lateral values. Longitudinal and transverse dispersivities for all formations were 0.1 and $0.01 \mathrm{~m}$, respectively. The molecular diffusion coefficient for both groundwater and river tracers was $7.94 \mathrm{E}-10 \mathrm{~m}^{2} \mathrm{~s}^{-1}$.

\begin{tabular}{lccccc}
\hline Material & $\begin{array}{c}K_{l}^{(\mathrm{a})} \\
\left(\mathrm{md}^{-1}\right)\end{array}$ & $\phi^{(\mathrm{b})}$ & $\begin{array}{c}\psi^{(\mathrm{c})} \\
(\mathrm{cm})\end{array}$ & $\lambda^{(\mathrm{d})}$ & $\theta_{r}^{(\mathrm{c})}$ \\
U1, Hanford gravel/sand & 1500 & 0.25 & 23.04 & 0.7465 & 0.1471 \\
U1, Hanford gravel/sand & $15000^{(\mathrm{f})}$ & 0.25 & 23.04 & 0.7465 & 0.1471 \\
U5, Ringold gravel/sand/silt (C/E) & 150 & 0.18 & 71.31 & 0.5193 & 0.1299 \\
U6, Ringold overbank mud & 0.01 & 0.18 & 71.31 & 0.5193 & 0.1299 \\
U7, Ringold gravel/sand/silt (B/D) & 43 & 0.18 & 71.31 & 0.5193 & 0.1299 \\
U8, Lower Ringold mud & $5 \mathrm{e}-5$ & 0.18 & 71.31 & 0.5193 & 0.1299 \\
Basalt & $5 \mathrm{e}-5$ & 0.18 & 71.31 & 0.5193 & 0.1299 \\
\hline
\end{tabular}

(a) Lateral hydraulic conductivity.

(b) Total and diffusive porosity.

(c) Entry head, minimum drainage capil lary head.

(d) Pore size distribution parameter.

(c) Minimum saturation.

(f) Hioh Ki sensitivity case

Figure D.4. Hydraulic Properties Used in 300 Area Simulations by Yabusaki et al. (2008) and Waichler and Yabusaki (2005)

Aquifer hydraulic property estimates noted by previous investigators range in value greatly. For example, published K estimates span many orders of magnitude at different horizontal and vertical locations of the aquifer and between investigators. This is not surprising given the known heterogeneous and anisotropic nature of the aquifer in this area. The estimates made during field characterization of BSF/CSF wells (Section 4.3.1) fall well within the range of published values, and they represent sitespecific estimates of the aquifer near the BSF/CSF project site; however, based on values reported by others and given the hydrostratigraphic nature of the aquifer, it is expected that these properties vary laterally.

\section{D.2 Additional Well and Aquifer Test Results}

Field hydraulic characterization tests were conducted in each of the BSF/CSF production wells to evaluate well performance and further estimate aquifer properties. As noted earlier, a 60-hr constant rate pumping test in Well 2 was used to estimate the hydraulic conductivity $(\mathrm{K})$ of the upper Ringold Formation. The results from the pumping withdrawal test in Well 2 provided the most representative aquifer properties for the site. Additional pumping tests were performed in the other seven BSF/CSF production wells to evaluate well performance, sustainability, and the local-scale heterogeneity of the aquifer. However, these tests were shorter in duration (24 hrs) and fewer observation wells were located near the stress well.

This appendix contains the results of these additional step- and constant-rate pumping tests. Field and analytical methods are briefly discussed, particularly where they differ from those described above. Tables and graphs containing a summary of the well performance and aquifer hydraulic properties are included below. For the purposes of comparison, the results for tests in Well 2 are included here. 
In keeping with their intended purpose, the extraction wells (Wells 1-4) and injection wells (Wells 58) were tested with pumping withdrawal and injection tests, respectively. For the pumping withdrawal tests in the extraction wells, pumped water was allowed to freely infiltrate into the vadose zone in a neighboring field. Make-up water for the injection tests was obtained from Wells 1 and 2, and the newly constructed heating/cooling system infrastructure was used to route the water to the injection test wells. The proximity of the infiltration field to the extraction wells and the source wells to the injection wells creates a potential boundary effect. Constant-rate test durations were held to 24 hours to minimize this influence on the drawdown/buildup data.

\section{D.2.1 Step-Rate Pumping Tests}

Step-rate tests consisted of withdrawal (Wells 1-4) or injection (Wells 5-8) of water at multiple flow rates ranging from 100 to 800 gpm (Table D.1). Head responses at each flow rate were monitored continuously, and the maximum displacement for a given flow rate was used to determine specific capacity. Table D.1 contains a summary of the observed head displacement and calculated specific capacity for each of the eight BSF/CSF production wells over the range of discharge conditions. As expected, specific capacities vary as a function of the local hydrogeology, well design, direction of flow (withdrawal vs. injection), and magnitude of flow rate.

Wells 1, 2, and 4 on the extraction side have the lowest drawdown for a given flow rate (Figure D.5). Well 3 appears to have a very low efficiency - likely due to the unintentional creation of a low-K skin around the well during drilling and/or well construction.

The injection wells also show a range in capacity (Table D.1). Well 8 has considerably lower pressure buildup for a given injection flow rate (Figure D.6). The combined injection capacity appears to be adequate for the planned flow rates. The elevation of the geologic contact between the Hanford and Ringold formations is highly variable as a result of the dynamic erosional and depositional histories of these geologic formations (Appendix B). In Wells 2, 2b, and 2c the static water table is slightly below the Hanford-Ringold (H-R) contact, and the entire aquifer is within the Ringold Formation (Figures C.2-6). No geologic information was collected for Wells 1 and 2a, but based on the information from neighboring wells, it is reasonably inferred that the water table is also below the H-R contact at these locations. The water table extends slightly above the H-R contact (0.3 to 3 meters) in Wells 4-8 (Figures C.7-11).

Since the Hanford formation is typically more permeable than the Ringold Formation, wells 4-8 might be expected to be more transmissive those with no saturated Hanford formation. Surprisingly, Well 4 has the thickest interval of saturated Hanford formation (3 meters) but does not show a noticeably higher specific capacity compared to other extraction wells (Table D.1 and Figure D.5). The thin layer of Hanford sediments are quickly dewatered when withdrawal rates exceed $\sim 400$ gpm. However, the opposite is true for the injection Wells 5-8. Injection capacities increase with flow rate in the injection wells. As the head in the well increases due to injection pressure buildup, more of the injected water is transmitted through the highly-permeable Hanford formation sediments. For comparison, step-rate withdrawal and injection tests were performed in Well 6. The results indicate that injection capacities were higher than withdrawal capacities in the well (Table D.1). Hydraulic properties estimated from injection tests in Wells 5-8 are representative of the depth-integrated average of the combined upperRingold and lower-Hanford formation sediments since the test interval spans across the H-R contact. 
Table D.1. Summary of Well Performance Testing Results for BSF/CSF Wells

\begin{tabular}{|c|c|c|c|c|}
\hline $\begin{array}{c}\text { Well } \\
\text { Name }\end{array}$ & Test Type & $\begin{array}{l}\text { Pumping } \\
\text { Rate } \\
\text { (gpm) }\end{array}$ & $\begin{array}{c}\text { Total Head } \\
\text { Displacement } \\
(\mathrm{ft}) \\
\end{array}$ & $\begin{array}{l}\text { Specific } \\
\text { Capacity } \\
(\mathrm{gpm} / \mathrm{ft})\end{array}$ \\
\hline \multirow{5}{*}{ Well 1} & \multirow{17}{*}{ Withdrawal } & 100 & 0.24 & 417 \\
\hline & & 200 & 0.72 & 278 \\
\hline & & 400 & 2.1 & 190 \\
\hline & & 550 & 3.5 & 157 \\
\hline & & 690 & 5.4 & 128 \\
\hline \multirow{5}{*}{ Well 2} & & 100 & 0.28 & 357 \\
\hline & & 215 & 0.73 & 295 \\
\hline & & 460 & 2.8 & 164 \\
\hline & & 630 & 5.8 & 109 \\
\hline & & 700 & 16.5 & 42 \\
\hline \multirow{3}{*}{ Well 3} & & 100 & 1.3 & 77 \\
\hline & & 200 & 4.0 & 50 \\
\hline & & 300 & 20.0 & 15 \\
\hline \multirow{4}{*}{ Well 4} & & 200 & 1.1 & 182 \\
\hline & & 400 & 3.1 & 129 \\
\hline & & 600 & 5.5 & 109 \\
\hline & & 745 & 9.2 & 81 \\
\hline \multirow{3}{*}{ Well 5} & \multirow{3}{*}{ Injection } & 400 & 5.5 & 73 \\
\hline & & 600 & 8.2 & 73 \\
\hline & & 800 & 10.8 & 74 \\
\hline \multirow{7}{*}{ Well 6} & \multirow{3}{*}{ Withdrawal } & 75 & 0.93 & 81 \\
\hline & & 150 & 2.2 & 68 \\
\hline & & 260 & 5.7 & 46 \\
\hline & \multirow{4}{*}{ Injection } & 200 & 2 & 100 \\
\hline & & 400 & 3.7 & 108 \\
\hline & & 600 & 5.4 & 111 \\
\hline & & 800 & 6.6 & 121 \\
\hline \multirow{5}{*}{ Well 7} & \multirow{8}{*}{ Injection } & 200 & 2.7 & 74 \\
\hline & & 400 & 4.5 & 89 \\
\hline & & 600 & 7 & 86 \\
\hline & & 785 & 8.4 & 93 \\
\hline & & 195 & 0.5 & 390 \\
\hline \multirow{3}{*}{ Well 8} & & 395 & 0.8 & 494 \\
\hline & & 600 & 1.4 & 429 \\
\hline & & 800 & 2.1 & 381 \\
\hline
\end{tabular}




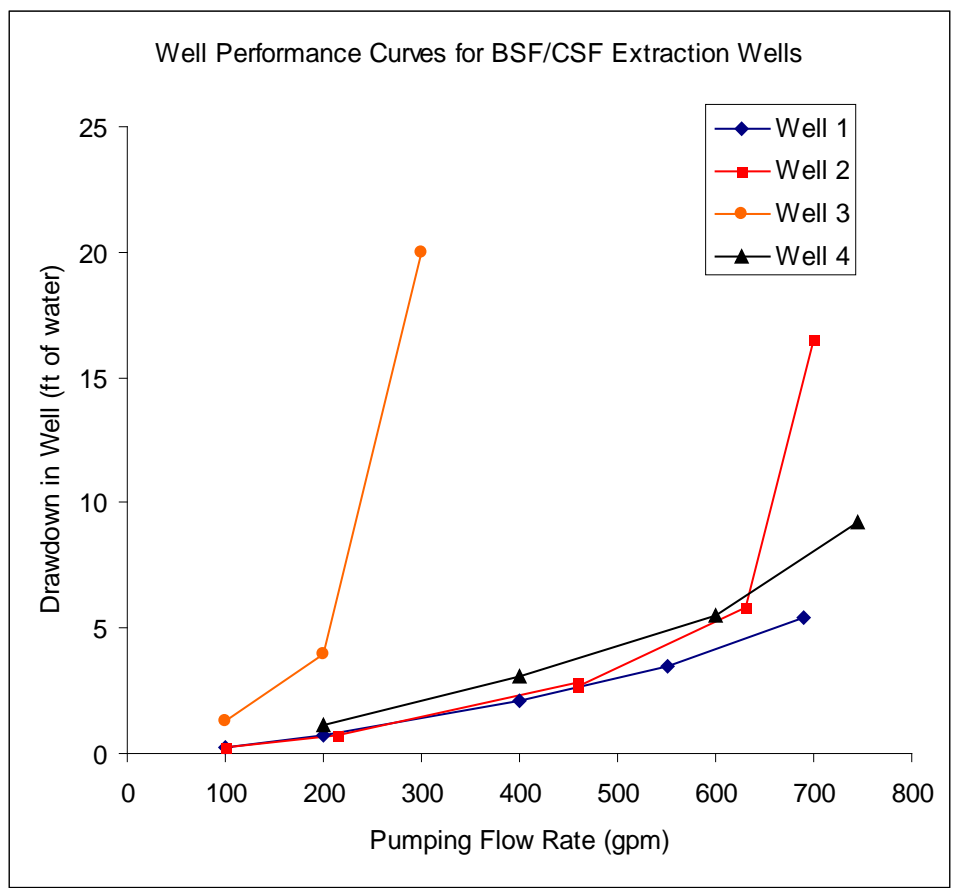

Figure D.5. Well Performance Curves for BSF/CSF Extraction Wells Showing Discharge-Drawdown Relation Under Pumping Withdrawal Conditions

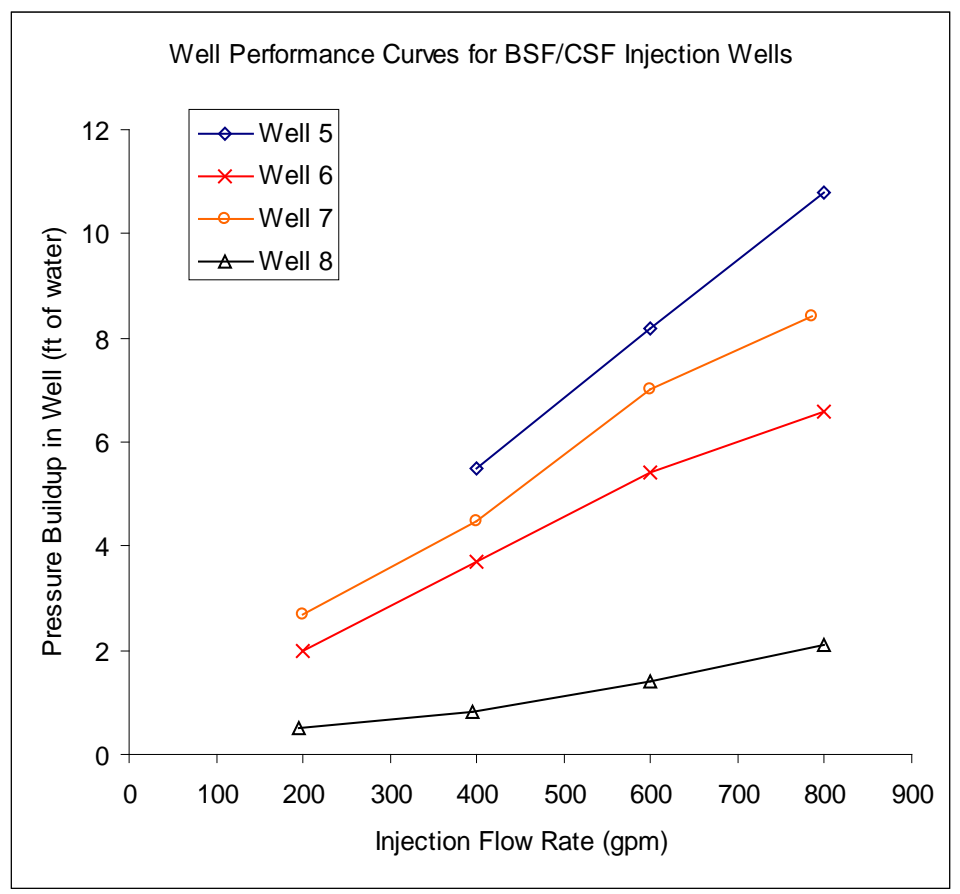

Figure D.6. Well performance curves for BSF/CSF injection wells showing discharge-buildup relation under pumping injection conditions. 


\section{D.2.2 Constant-Rate Pumping Tests}

Constant-rate pumping tests were performed in each of the eight BSF/CSF production wells. The drawdown results for the withdrawal test in Well 2 are also presented in Section 4.1.1. The results for the recovery data for Well 2 and the additional tests in the other seven wells are presented here for comparison and to provide added insight into the spatial heterogeneity and range of hydraulic properties for the local-scale aquifer.

Additional constant-rate pumping tests were run for 24 hours (compared to the 60-hr test in Well 2). Flow rates ranged from 180 to 557 gpm (Table D.2), and were held nearly constant; however, minor plugging of the sediment filtration system occurred during several tests and caused slight fluctuations. For this reason, the recovery data were used in the analysis. Well and aquifer responses were observed in the stress well and one or two neighboring production wells located about 55 meters (180 feet) away from the stress well.

The Cooper and Jacob (1946) approximation to the analytical solution of Theis (1935) was used to fit a straight line to the recovery data on a semi-log plot. Although the Cooper-Jacob approach was devised for use with confined aquifers, it can be used for unconfined aquifers through Jacob's (1963) correction for the effects of dewatering, assuming that infinite and radial flow conditions have been established (Kruseman and de Ridder 1990). The benefit to using a straight-line solution, rather than a type-curve solution, is that the aquifer transmissivity $(\mathrm{T}$ ) can be estimated in spite of well effects based on the rate of change in drawdown or recovery (i.e., the slope of the straight line). This is possible because head losses associated with the well (e.g., "skin” or inefficiency) are considered constant for a given flow rate. Thus, their effect is constant with time and does not affect the slope of the straight line. It is important to note that storage properties (storativity, S) determined from the Cooper-Jacob method for the stress well are affected by skin effects and were not determined in the analysis. Before the straight-line analysis, the recovery data were transformed into Agarwal-equivalent drawdown and time, which allows recovery data to be analyzed as an equivalent drawdown response (Agarwal 1980).

The Cooper-Jacob (1946) analytical solution assumes the aquifer is homogeneous, isotropic, of infinite areal extent, of uniform thickness, and ignores well-bore storage effects. As discussed in Section D.2.1, the position of the Hanford-Ringold (H-R) formation contact relative to the water table and the type of pumping test (withdrawal vs. injection) has an effect on hydraulic test results and needs to be considered. There is 0.3 to 3 meters of saturated Hanford formation in Wells 4-8. In the case of Well 4, pumping withdrawal dewatered the thin zone of Hanford formation during drawdown and had little impact on results; thus, results from Well 4 represent estimates primarily for Ringold Formation sediments.

Injection tests in Wells 5-8 involved pressure buildup or "mounding” of the water table within the well/aquifer, thus increasing the saturated thickness and test interval of the Hanford formation. Hydraulic property estimates from injection tests in Well 5-8 are representative of the combined gravel-dominated zone of sediments within the lower Hanford and upper Ringold formations. They provide an indication of the upper bound on the range of site-specific hydraulic conductivity of the unconfined aquifer.

Hydraulic conductivity (K) values were calculated from the analytically-derived transmissivity $(\mathrm{T})$ estimates using a prescribed saturated thickness (b) of 18 meters (60 feet) according to $\mathrm{T}=\mathrm{K} / \mathrm{b}$. This 
represents the average saturated thickness between the water table and the bottom of the unconfined aquifer (Ringold lower fine-grained subunit) at the BSF/CSF site (Figure B.2).

Hydraulic conductivity (K) estimates obtained from the Cooper-Jacob (1946) analysis of recovery data for the four Ringold-only test interval wells (Wells 1-4) range from 59 to $133 \mathrm{~m} / \mathrm{d}$ (194 to $435 \mathrm{ft} / \mathrm{d}$ ) (Table D.2 and Figures D.7 through Figure D.15). Among the four Ringold-Formation extraction wells, Wells 1 and 3 and exhibited the highest and lowest K estimates, respectively. This is not surprising given the spatially heterogeneous nature the sediments.

The K estimates from tests in the four injection wells on the east side of the BSF/CSF site exhibited a larger range and higher average as a result of the having saturated Hanford formation sediments within aquifer test interval. The test interval for these wells is the combined lower-Hanford/upper-Ringold gravel-dominated sediments. The presence of the permeable Hanford gravels within the aquifer decreased the pressure buildup response and resulted in a higher K estimate. The average K estimates for tests these wells ranged from 102 to $278 \mathrm{~m} / \mathrm{d}$ (334 to $913 \mathrm{ft} / \mathrm{d}$ ). Wells 5 and 8 exhibited the lowest and highest $\mathrm{K}$ responses, respectively, despite the fact that Well 5 has the highest amount of saturated Hanford formation. This suggests that the contrast in hydraulic conductivity between the upper Ringold gravels and the lower Hanford gravels is less than typically expected.

These additional test results generally agree with those presented in Section 4.1.1 for the extendedduration (60-hr) pumping withdrawal test in Well 2. The range and distribution of test responses in all the tests are consistent with and can for the most part, be explained by differences in hydrogeology, well design, and test type. The spatial heterogeneity of the aquifer sediments makes it difficult to assign a single K estimate for the entire unconfined aquifer. The complex depositional environment and erosional history of the hydrogeologic layers create significant spatial heterogeneity. Selecting a single defensible K estimate to represent the Ringold Formation for the site represented in the simulation domain is challenging and introduces an unknown amount of uncertainty. Based on field data at the BSF/CSF site and the range of hydraulic properties reported by others in the 1100 and 300 Areas, demonstrates that a range of $\mathrm{K}$ values exists for the site. Providing a range of $\mathrm{K}$ values more fully addresses hydrogeologic uncertainty. For example, if the aquifer thickness is less than what was assumed in this analysis, then the $\mathrm{K}$ values are higher than the reported values. Hence, saturated hydraulic conductivity estimates of 60 and $150 \mathrm{~m} / \mathrm{d}$ are consistent with the range of probable and observed Ringold Formation estimates in BSF/CSF production wells using both drawdown and recovery data. 
Table D.2. Hydraulic Conductivity Estimates from Constant-Rate Pumping Tests in BSF/CSF Wells

\begin{tabular}{|c|c|c|c|c|}
\hline Test Type & Test Well & $\begin{array}{l}\text { Average } \\
\text { Flow Rate } \\
\text { (gpm) }\end{array}$ & $\begin{array}{l}\text { Well Response } \\
\text { Analyzed }\end{array}$ & $\begin{array}{l}\text { Hydraulic } \\
\text { Conductivity, K, } \\
\text { m/day (ft/day) }\end{array}$ \\
\hline \multirow{15}{*}{ Withdrawal } & \multirow{3}{*}{ Well 1} & \multirow{3}{*}{557} & Well 1 & $142(467)$ \\
\hline & & & Well 2 & $123(403)$ \\
\hline & & & Avg. & $133(435)$ \\
\hline & \multirow{6}{*}{ Well 2} & \multirow{6}{*}{400} & Well 2 & $70(230)$ \\
\hline & & & Well 1 & $113(370)$ \\
\hline & & & Well 2a & 76 (250) \\
\hline & & & Well 2b & $73(240)$ \\
\hline & & & Well 2c & 70 (230) \\
\hline & & & Avg. & 81 (264) \\
\hline & \multirow{3}{*}{ Well 3} & \multirow{3}{*}{180} & Well 3 & 47 (155) \\
\hline & & & Well 2 & $71(233)$ \\
\hline & & & Avg. & 59 (194) \\
\hline & \multirow{3}{*}{ Well 4} & \multirow{3}{*}{447} & Well 4 & 59 (195) \\
\hline & & & Well 3 & 66 (217) \\
\hline & & & Avg. & 62 (206) \\
\hline \multirow{14}{*}{ Injection } & \multirow{3}{*}{ Well 5} & \multirow{3}{*}{450} & Well 5 & 81 (267) \\
\hline & & & Well 6 & $122(400)$ \\
\hline & & & Avg. & 102 (334) \\
\hline & \multirow{4}{*}{ Well 6} & \multirow{4}{*}{500} & Well 6 & $60(190)$ \\
\hline & & & Well 5 & 107 (350) \\
\hline & & & Well 7 & 271 (888) \\
\hline & & & Avg. & $145(476)$ \\
\hline & \multirow{4}{*}{ Well 7} & \multirow{4}{*}{500} & Well 7 & $268(878)$ \\
\hline & & & Well 6 & $356(1,167)$ \\
\hline & & & Well 8 & 212 (695) \\
\hline & & & Avg. & 278 (913) \\
\hline & \multirow{3}{*}{ Well 8} & \multirow{3}{*}{500} & Well 8 & 224 (735) \\
\hline & & & Well 7 & $274(900)$ \\
\hline & & & Avg. & 249 (818) \\
\hline \multicolumn{5}{|c|}{$\begin{array}{l}\text { Note: An aquifer thickness (b) of } 60 \text { feet for the site was used in the calculation of hydraulic } \\
\text { conductivity (K) from the estimates of transmissivity }(\mathrm{T}) ; \mathrm{K}=\mathrm{T} / \mathrm{b} \text {. Estimates were obtained } \\
\text { using Cooper-Jacob straight-line method of analysis on the Agarwal-transformed recovery } \\
\text { data. }\end{array}$} \\
\hline
\end{tabular}



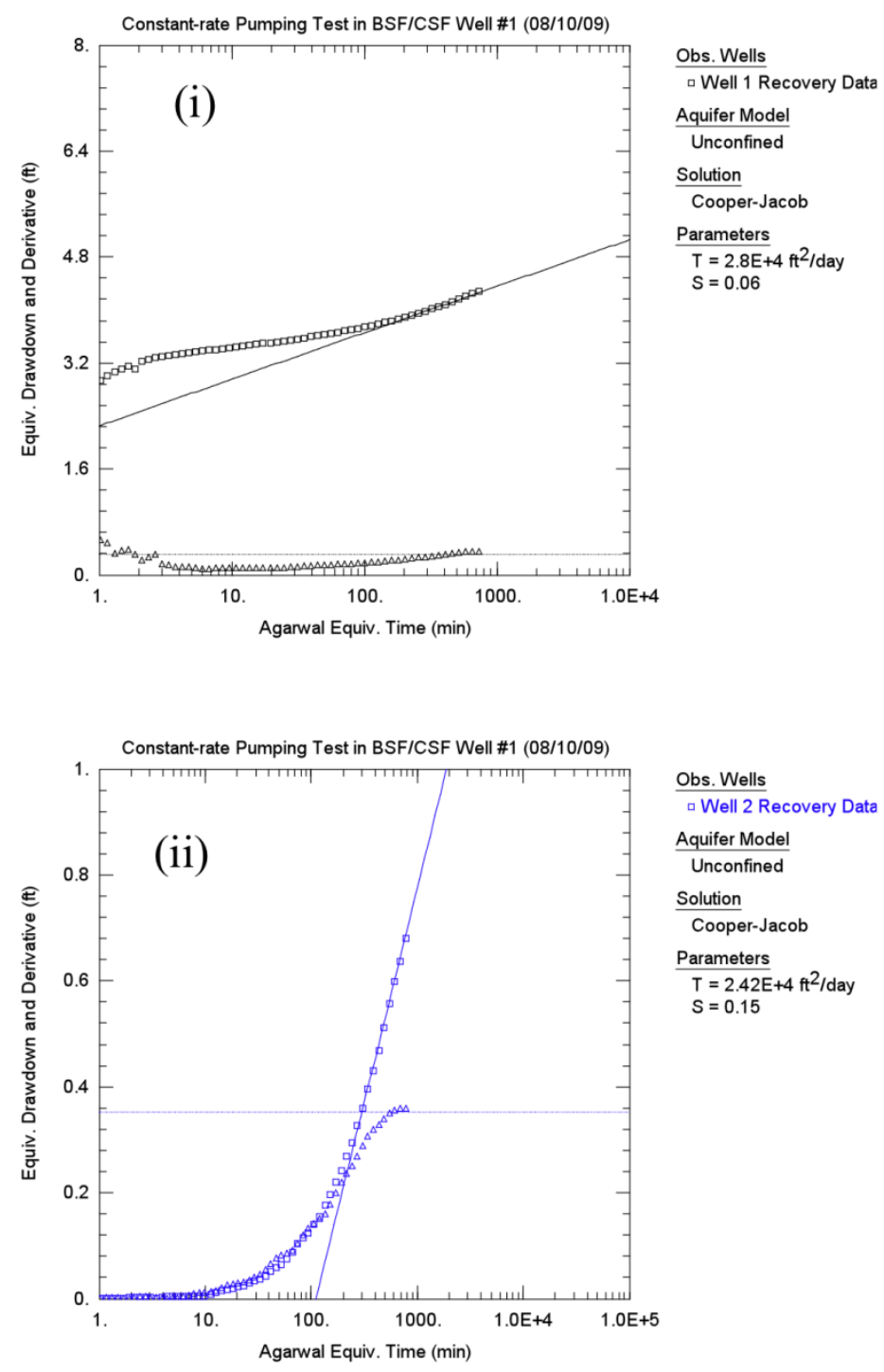

Figure D.7. Straight-Line Fits to the Recovery Data for the Constant-Rate Withdrawal Test in Well 1 as Observed in Well 1 (i) and Well 2 (ii) 

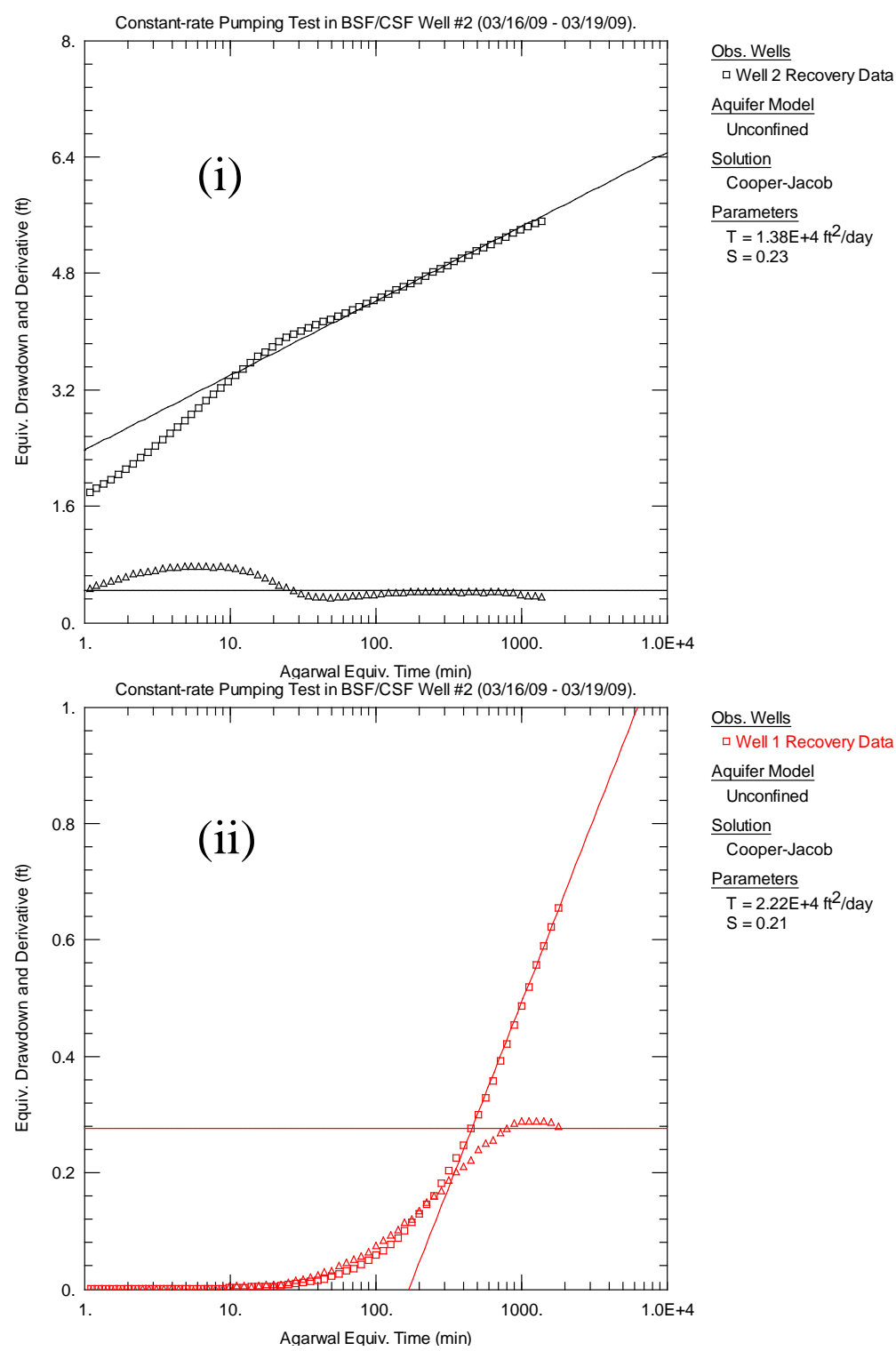

Figure D.8. Straight-line Fits to the Recovery Data for the Constant-rate Withdrawal test in Well 2 as Observed in Well 2 (i) and Well 1 (ii). 

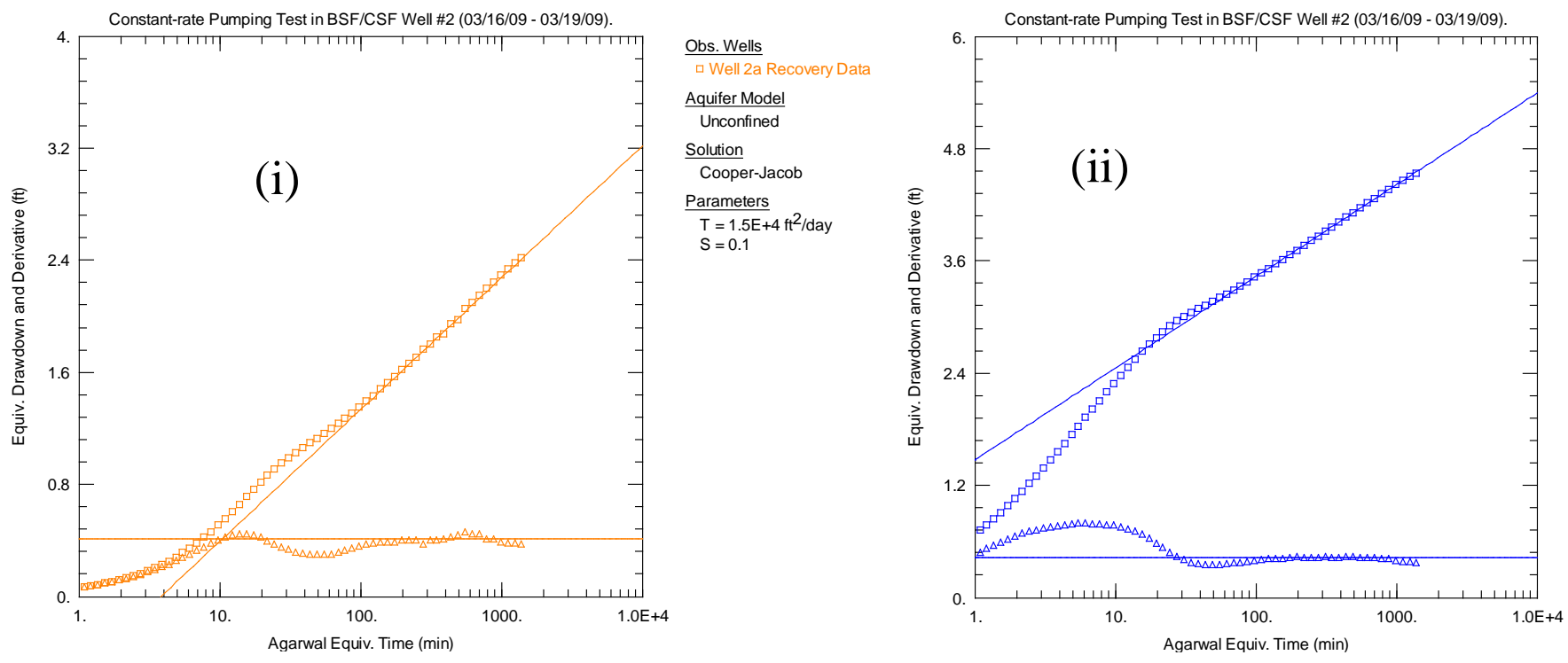

Obs. Wells

$\square$ Well 2b Recovery Data

Aquifer Model

Unconfined

$\underline{\text { Solution }}$

Cooper-Jacob

Parameters

$T=1.44 \mathrm{E}+4 \mathrm{ft}^{2} / \mathrm{day}$

$\mathrm{S}=0.011$

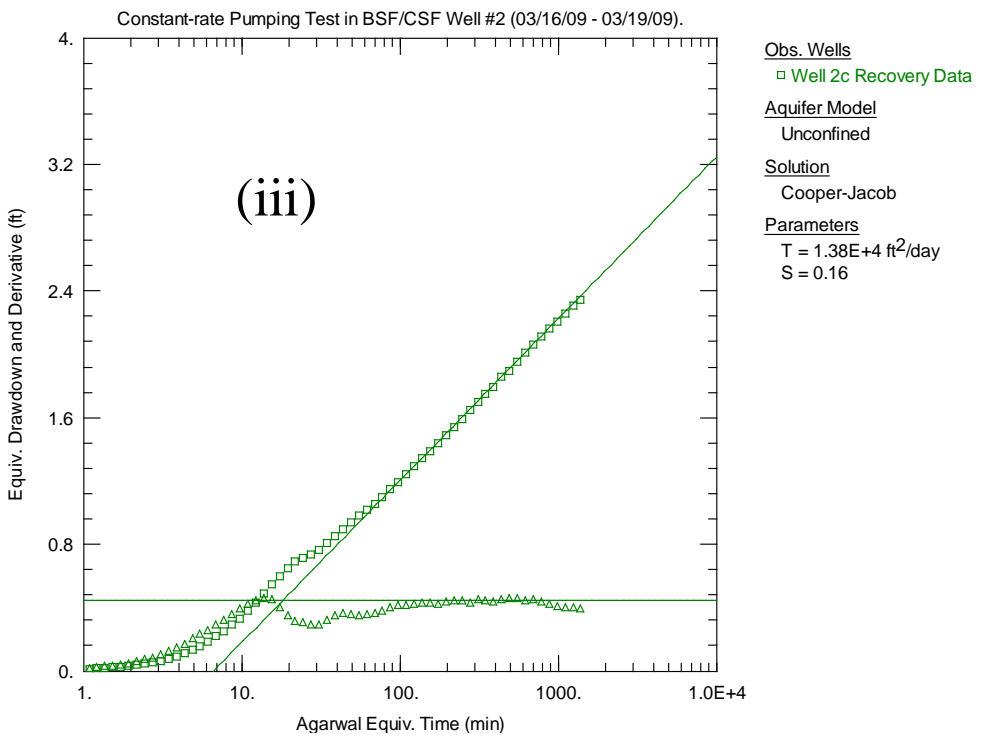

Figure D.9. Straight-line Fits to the Recovery Data for the Constant-rate Withdrawal test in Well 2 as Observed in Wells (i) 2a, (ii) 2b and (iii) 2c 

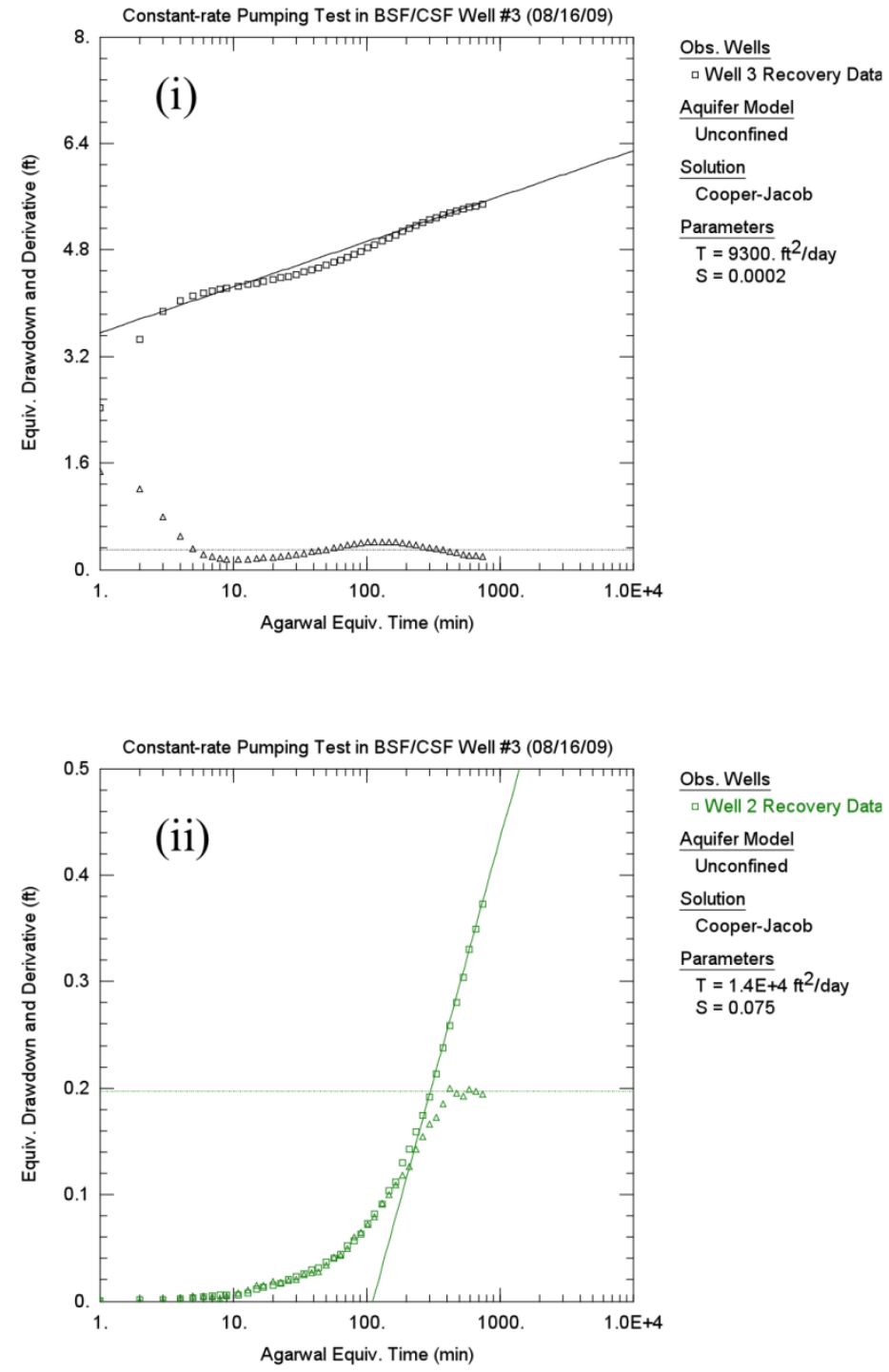

Figure D.10. Straight-line Fits to the Recovery Data for the Constant-rate Withdrawal test in Well 3 as Observed in Well 3 (i) and Well 2 (ii). 

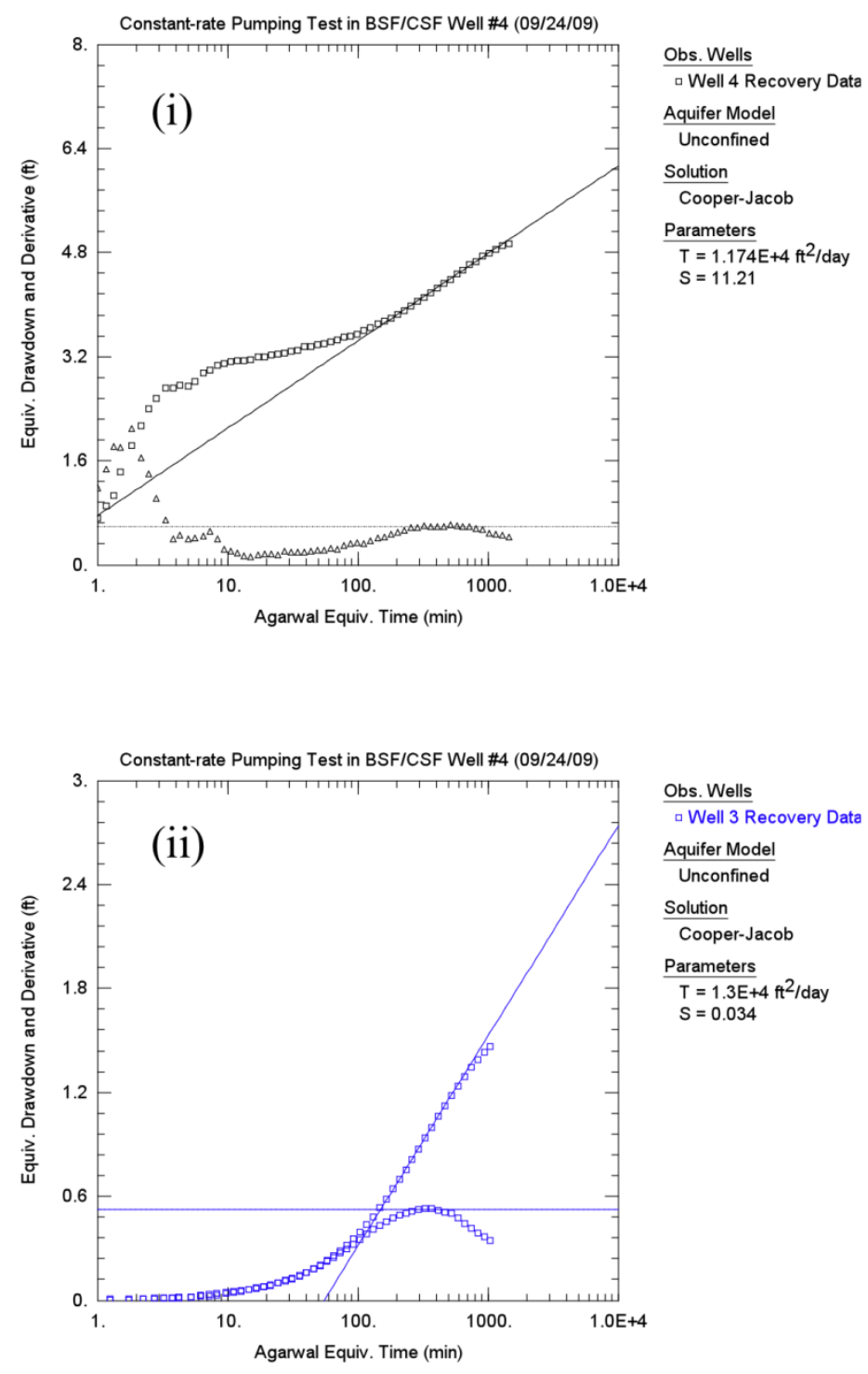

Figure D.11. Straight-Line Fits to the Recovery Data for the Constant-Rate Withdrawal Test in Well 4 as Observed in Well 4 (i) and Well 3 (ii) 

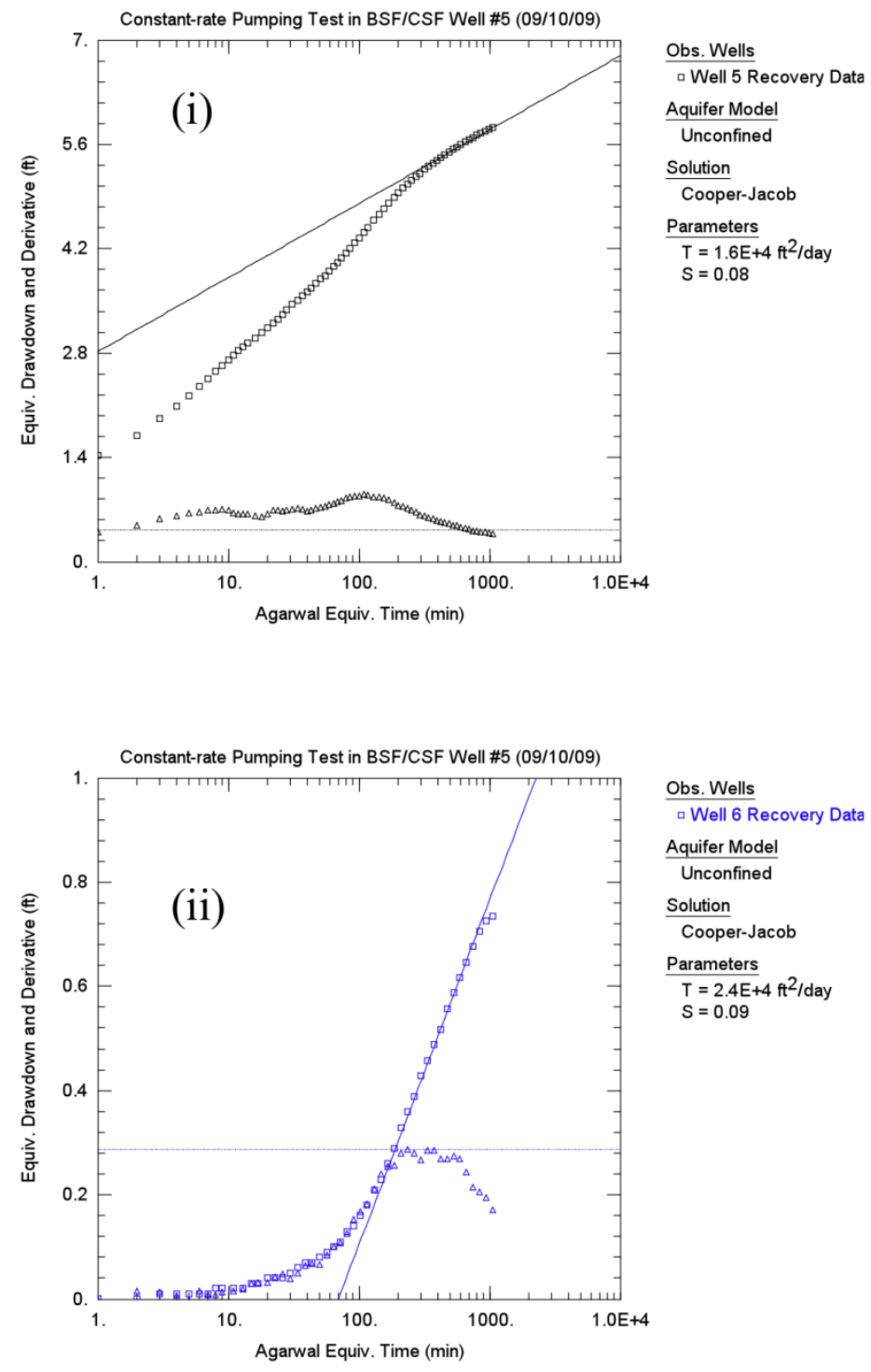

Figure D.12. Straight-Line Fits to the Recovery Data for the Constant-Rate Injection Test in Well 5 as Observed in Well 5 (i) and Well 6 (ii) 

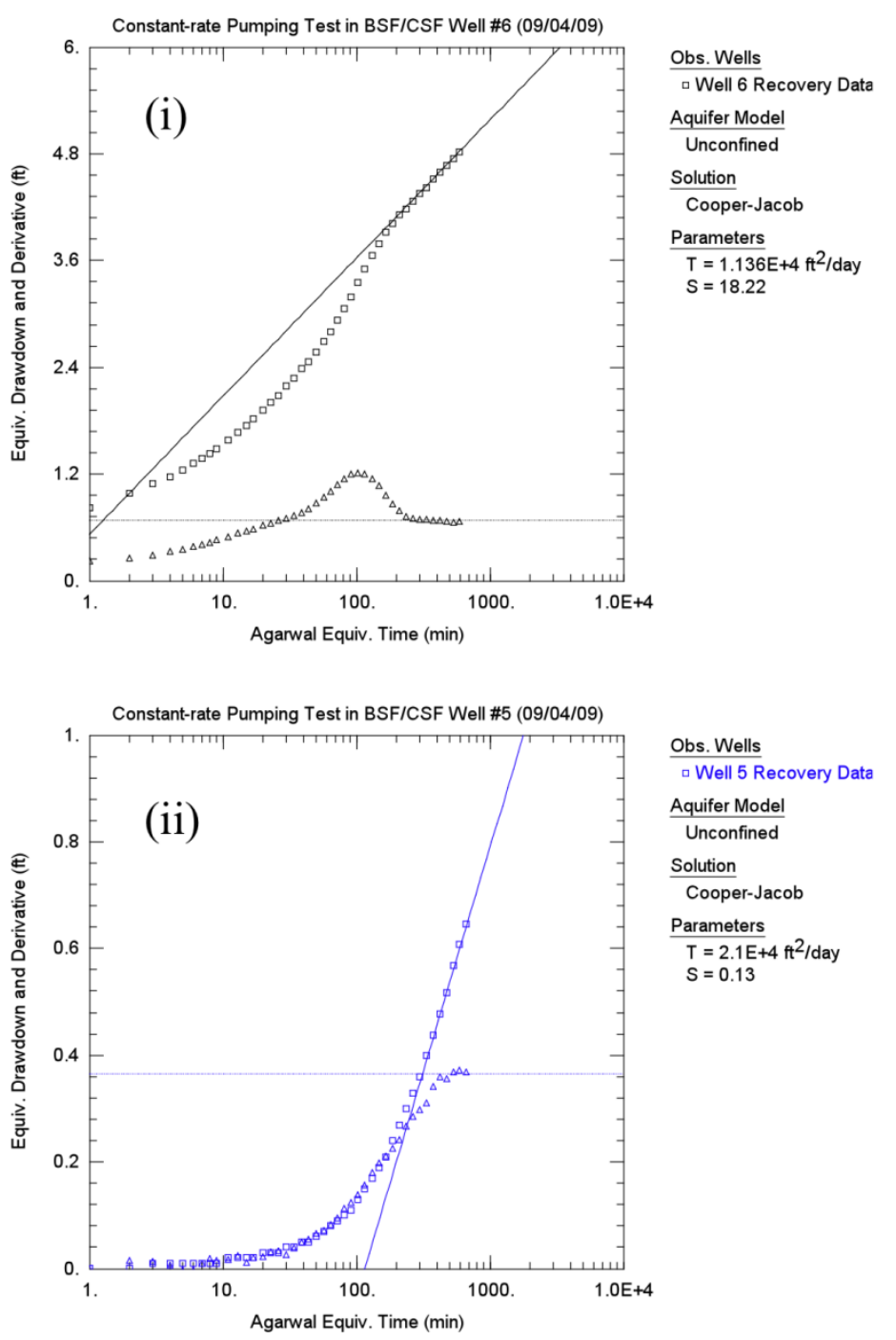

Obs. Wells

$\square$ Well 5 Recovery Data

Aquifer Model

Unconfined

Solution

Cooper-Jacob

Parameters

$T=2.1 \mathrm{E}+4 \mathrm{ft}^{2} /$ day

$S=0.13$

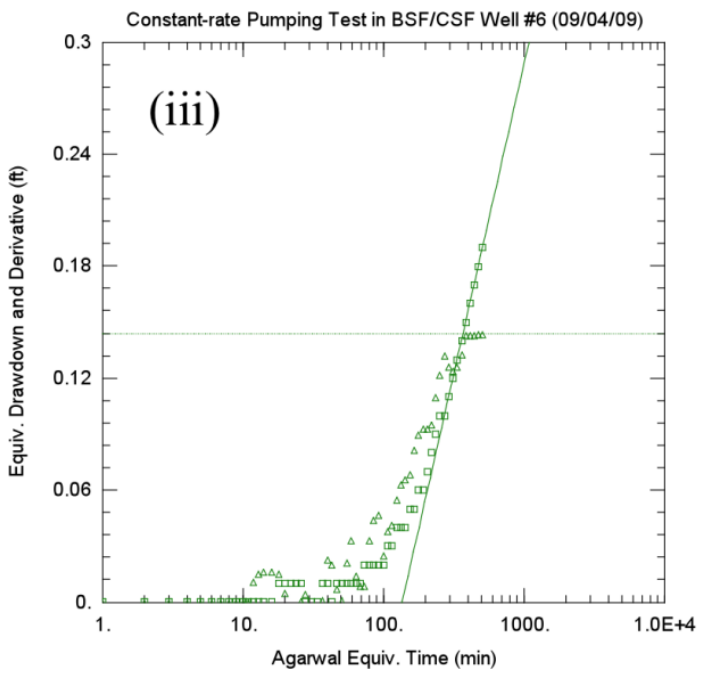

Obs. Wells

- Well 7 Recovery Data

Aquifer Model

Unconfined

Solution

Cooper-Jacob

Parameters

$T=5.33 \mathrm{E}+4 \mathrm{ft}^{2} /$ day

$S=0.224$

Figure D.13. Straight-Line Fits to the Recovery Data for the Constant-Rate Injection Test in Well 6 as Observed in Well 6 (i), Well 5 (ii), and Well 7 (iii)

D.17 

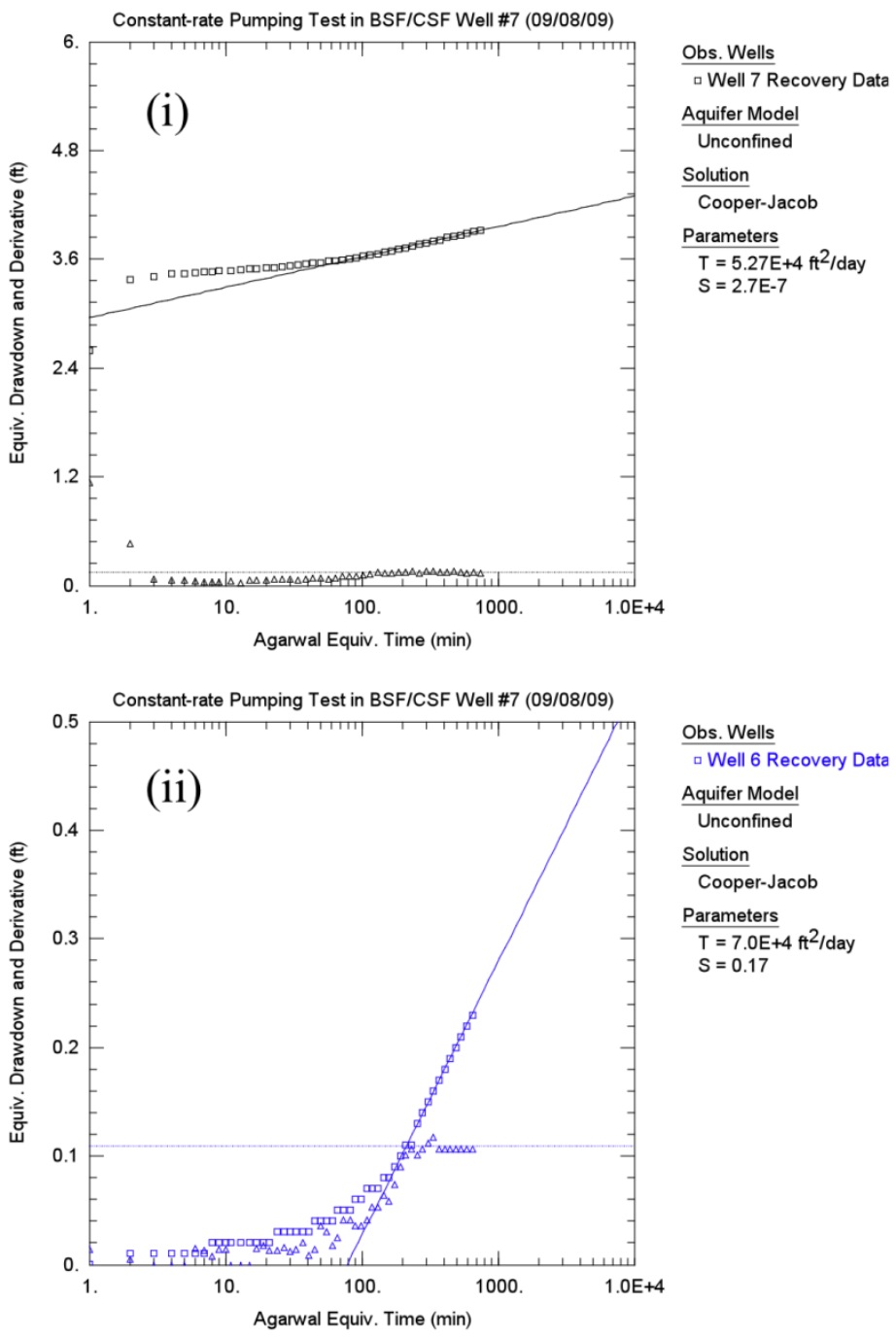

Obs. Wells

a Well 6 Recovery Data

Aquifer Model

Unconfined

Solution

Cooper-Jacob

Parameters

$T=7.0 \mathrm{E}+4 \mathrm{ft}^{2} /$ day

$S=0.17$

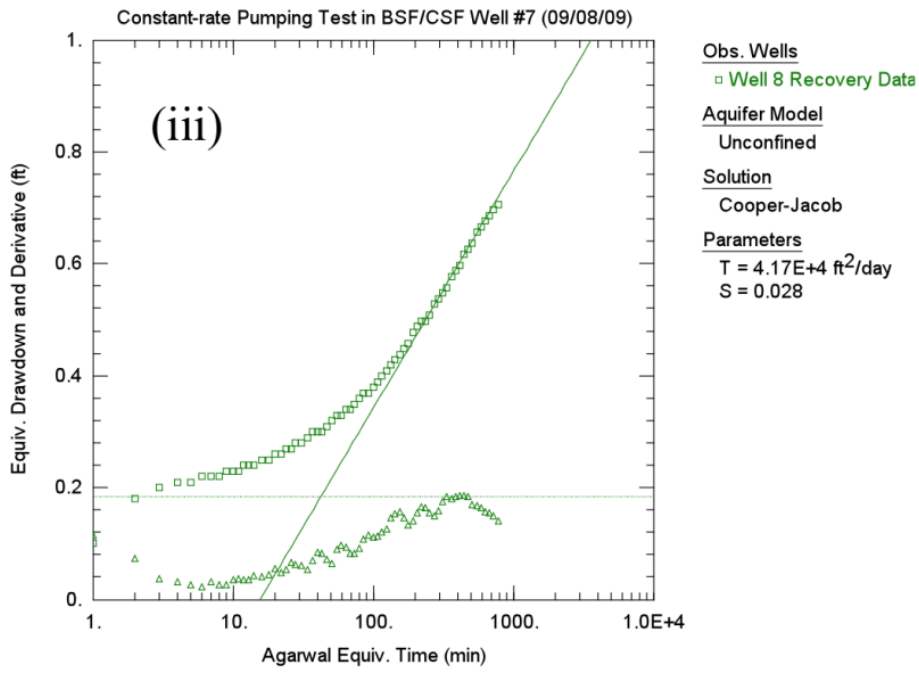

Figure D.14. Straight-Line Fits to the Recovery Data for the Constant-Rate Injection Test in Well 7 as Observed in Well 7 (i), Well 6 (ii), and Well 8 (iii) 

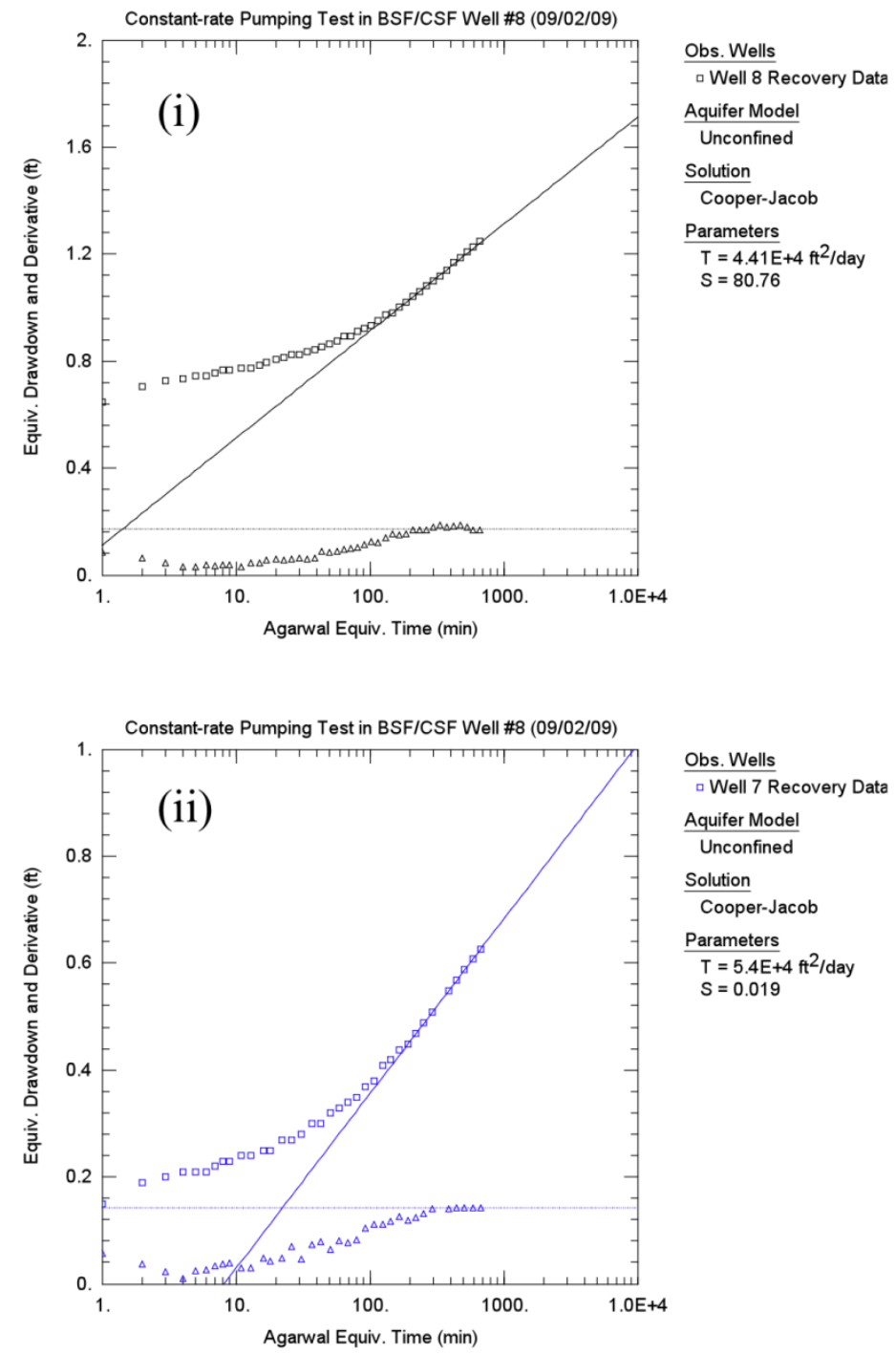

Figure D.15. Straight-Line Fits to the Recovery Data for the Constant-Rate Injection Test in Well 8 as Observed in Well 8 (i) and Well 7 (ii)

\section{D.2.3 Electromagnetic Borehole Flowmeter Tests}

Three of the BSF/CSF wells (Wells 1, 2, and 2a) were surveyed with an electromagnetic borehole flowmeter (EBF) to assess the vertical distribution of groundwater in-flow. EBF surveys are effective for measuring the vertical groundwater-flow velocity distribution in wells. The measurements of vertical groundwater-flow velocity can be used to infer the lateral groundwater in-flow distribution. The objective of EBF surveys is to characterize the ambient (i.e., static) or dynamic (i.e., pump-induced), inwell vertical flow conditions (i.e., vertical flow-velocity magnitude and direction) within the saturated well-screen section. The primary objective was to examine the vertical distribution of relative hydraulic conductivity within the aquifer at these well locations.

Field observations of borehole lithologic samples suggested that the upper gravel-dominated zone of the aquifer is more transmissive than the middle (finer grained) and lower zones (more compacted gravels). Because of the uncertainty associated with the depth of the high-permeable zones, the EBF 
method was employed to help map the relative hydraulic conductivity vertically in the aquifer. This method is one of the most effective field characterization tools currently available to assess the vertical variation in hydraulic conductivity (Butler 2005, Chapter 2, pp. 23-25).

A generalized field setup for the EBF testing is illustrated in Figure D.16. The general test procedure for conducting the EBF surveys is to raise the EBF in succession at discrete depth intervals within the saturated well-screen section and measure the vertical flow velocity during a constant rate of pumping (Young and Pearson 1995, Butler 2005, Spane and Newcomer 2008). During April 2009, Wells 1, 2, and 2a were surveyed with the EBF. Two tests for each well—an ambient flow test for measuring background vertical flow, followed by a dynamic flow test for measuring pump-induced vertical flowwere used to infer the vertical distribution of relative hydraulic conductivity. During the dynamic flow tests, a submersible pump (Grundfos Redi-Flow 2) was used to induce a flow gradient within the well, with flow held at a constant discharge rate. A discharge flow rate of $\sim 2 \mathrm{gpm}$ was used for the dynamic test in the 4-in.-diameter observation well 2a. Because of the potential for bypass flow, a higher flow rate of $\sim 4$ gpm was required for the dynamic tests in the larger diameter Wells 1 and 2.

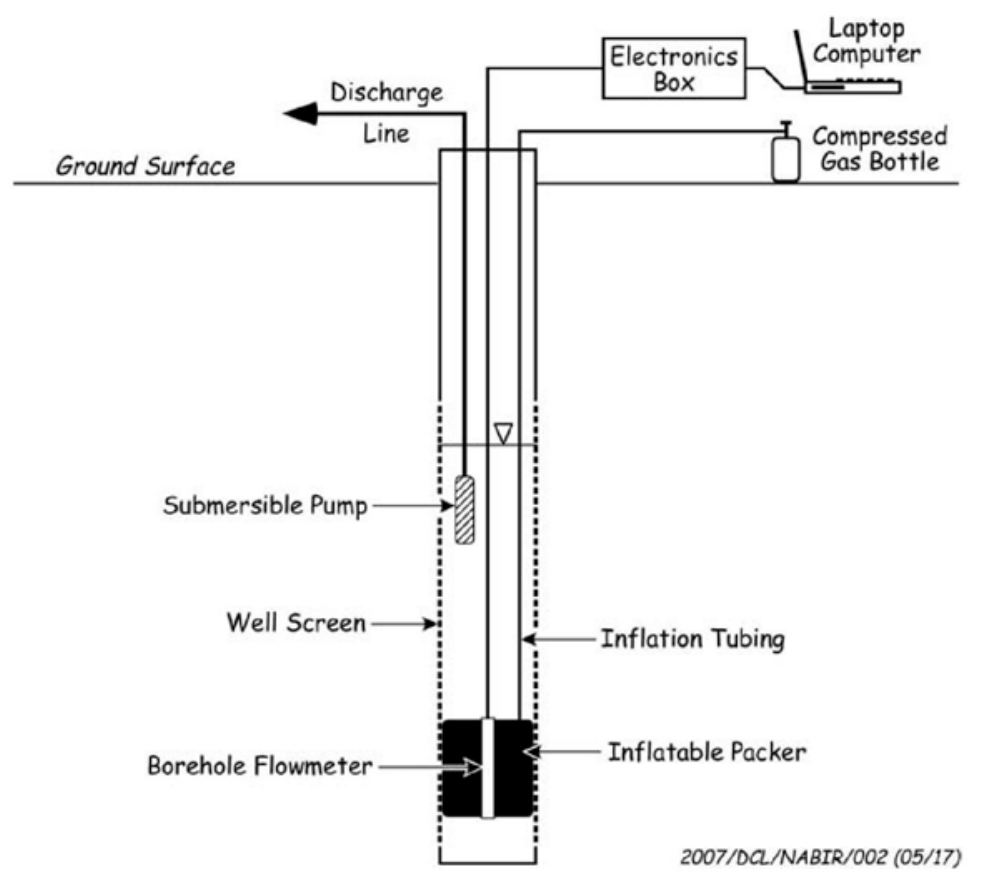

Figure D.16. General Configuration for EBF Survey for Profiling the Vertical Distribution of Groundwater In-Flow

The results of the dynamic EBF test in well 2a provided the most reliable test data because little or no flow bypassed the instrument during the test. The data were analyzed to examine the vertical distribution of relative hydraulic conductivity inferred from the induced-flow vertical flow-rate measurements at discrete depths within the well-screen section. Well 2a is constructed with a 4-in,-diameter PVC screen at a depth of 45 - to 103-ft bgs. Note that the vertical in-well flow could not be measured with the EBF below 94 -ft bgs because of sand in-filling the bottom 9 feet of the well. The profile of relative hydraulic conductivity indicates that the upper 20 to 25 feet of the aquifer showed the highest relative $\mathrm{K}$ values (Figure D.17). Below 75-ft bgs, where lateral in-well flow was low, the relative hydraulic conductivity is lower than the relative $\mathrm{K}$ indicated for the upper zone of the aquifer. 
The dynamic EBF tests in the larger diameter wells (Wells 1 and 2) exhibited a large degree of bypass flow around the EBF to the extent that the dynamic flow results are less reliable for analysis. The vertical flow profiles exhibited a high flow contribution near the very upper part of the well-screen section and little flow contribution from most of the lower part of the screen. This type of profile is reflective of significant vertical bypass flow through the filter pack surrounding the well screen (Boman et al. 1997) and suggests the well has a high vertical permeability annulus surrounding the well. Flow through such an annulus is isolated from flow through the EBF in the lower part of the well-screen section and becomes bypass flow in the upper part of the well-screen section where flow through the EBF will be large. A portion of the water may have also flowed around the EBF, in between the packer and the well screen, because of the space created by the vertical support rods welded to the inside of the stainless-steel screens. As a result, an analysis would lead to an erroneously high permeability zone at the top of the well-screen section.

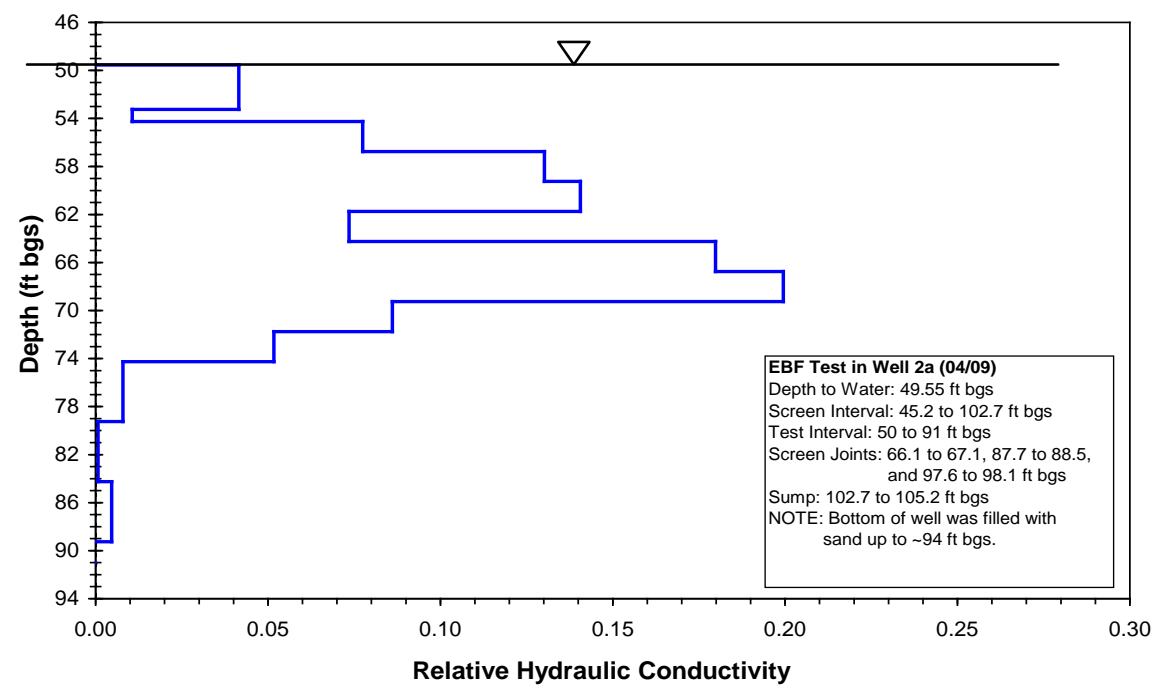

Figure D.17 Profile Showing the Vertical Distribution of Relative Hydraulic Conductivity from Dynamic EBF Tests Conducted in Well 2a 
Appendix E

Heat Transport Results

Case 1a (60 m/d Ringold Hydraulic Conductivity, Average Scenario) 


\section{Appendix E: Heat Transport Results:}

Case 1a (60 m/d Ringold Hydraulic Conductivity, Average Scenario)
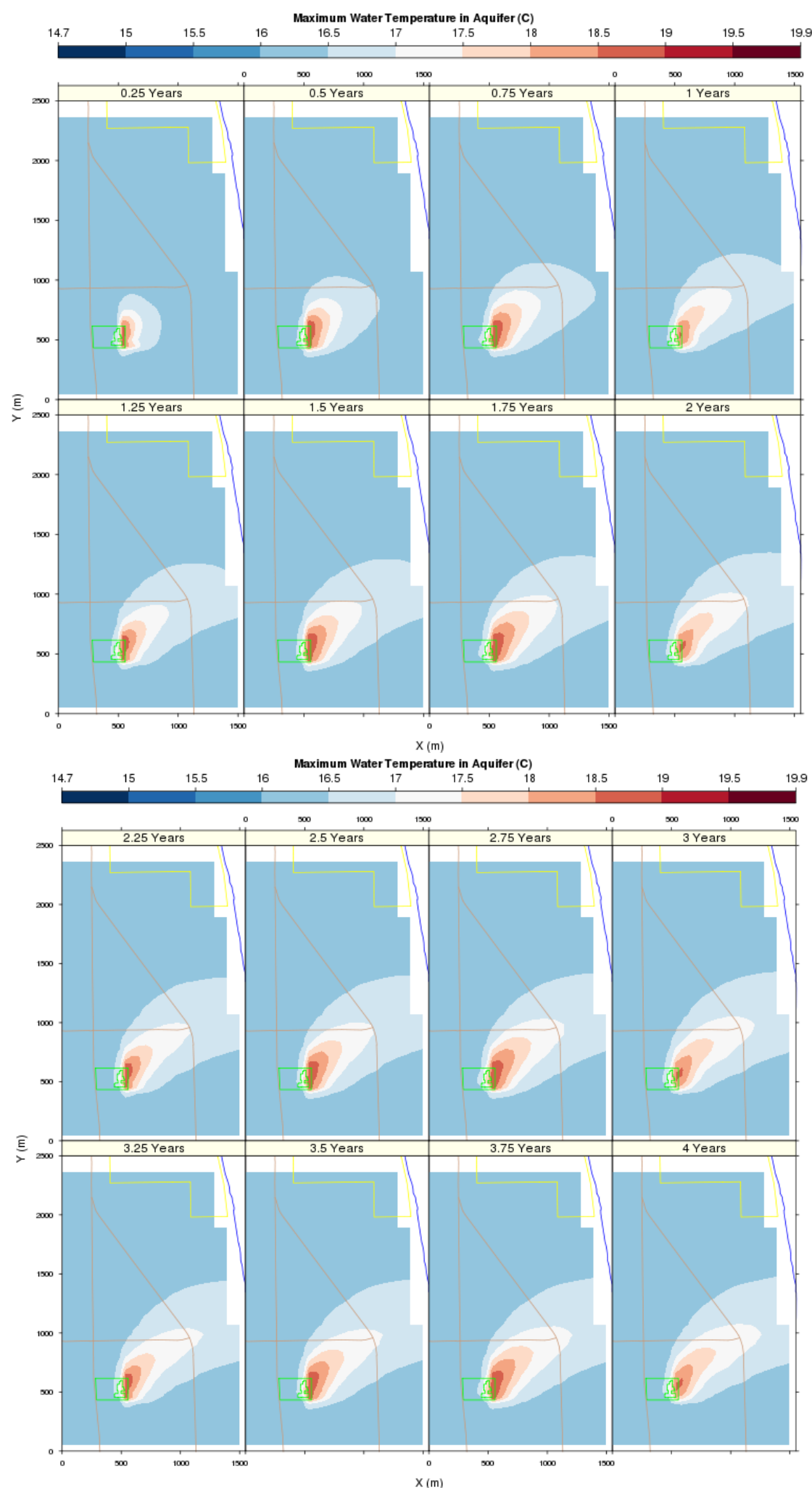

Figure E.1. Maximum Temperature Distribution for Case 1a At Quarter Year Intervals

E.1 

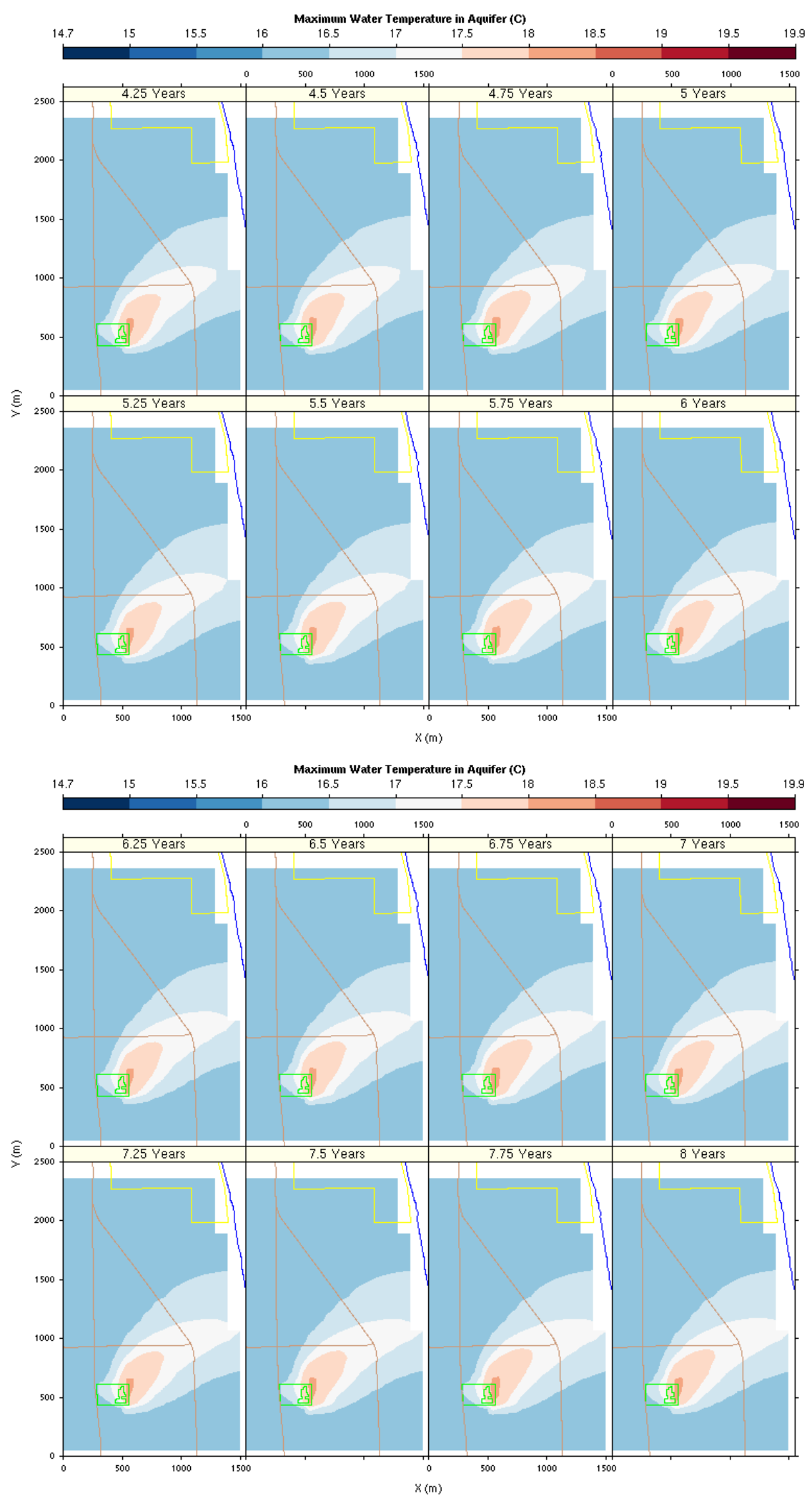

Figure E.1 (contd) 

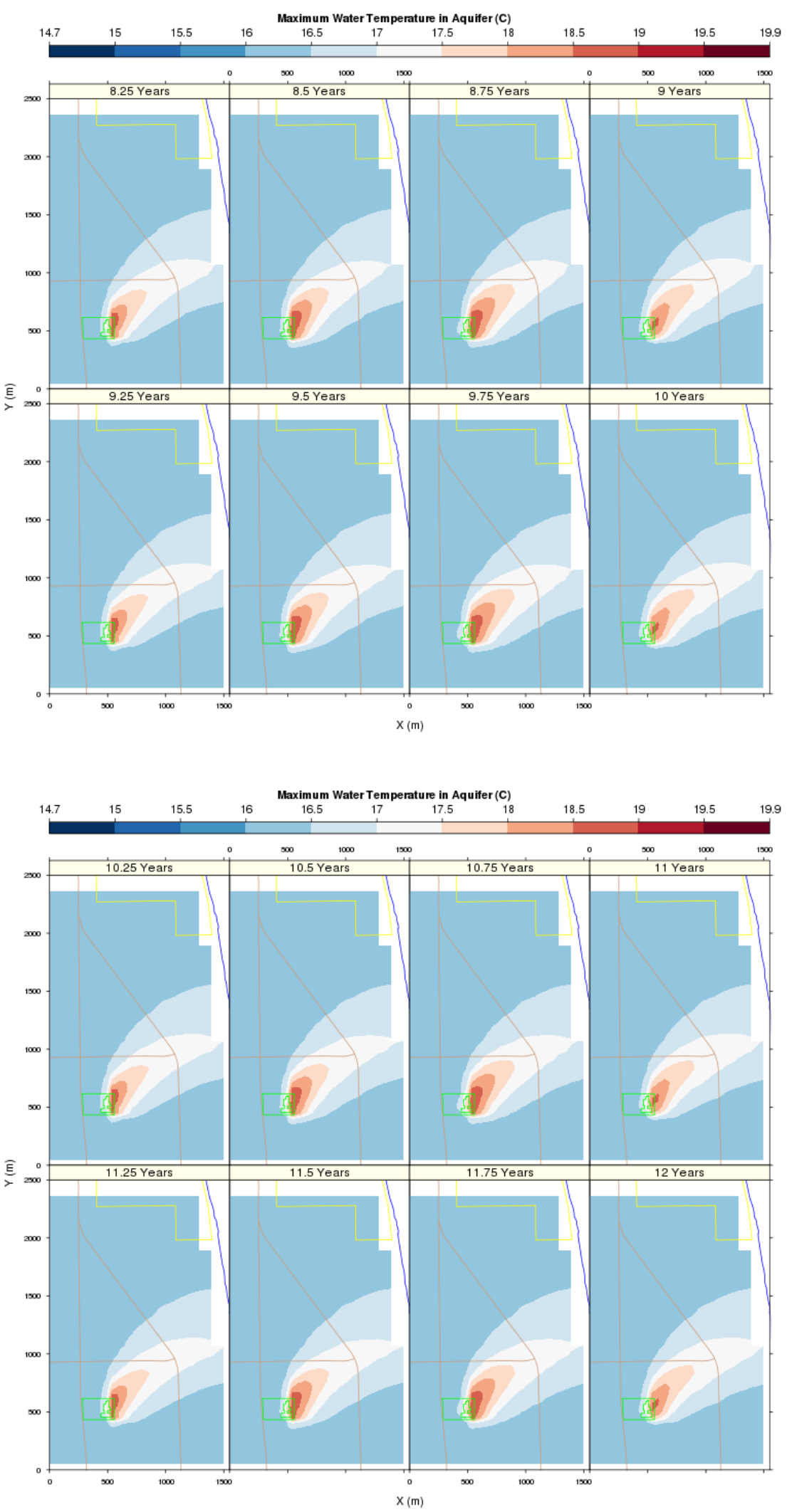

Figure E.1 (contd) 

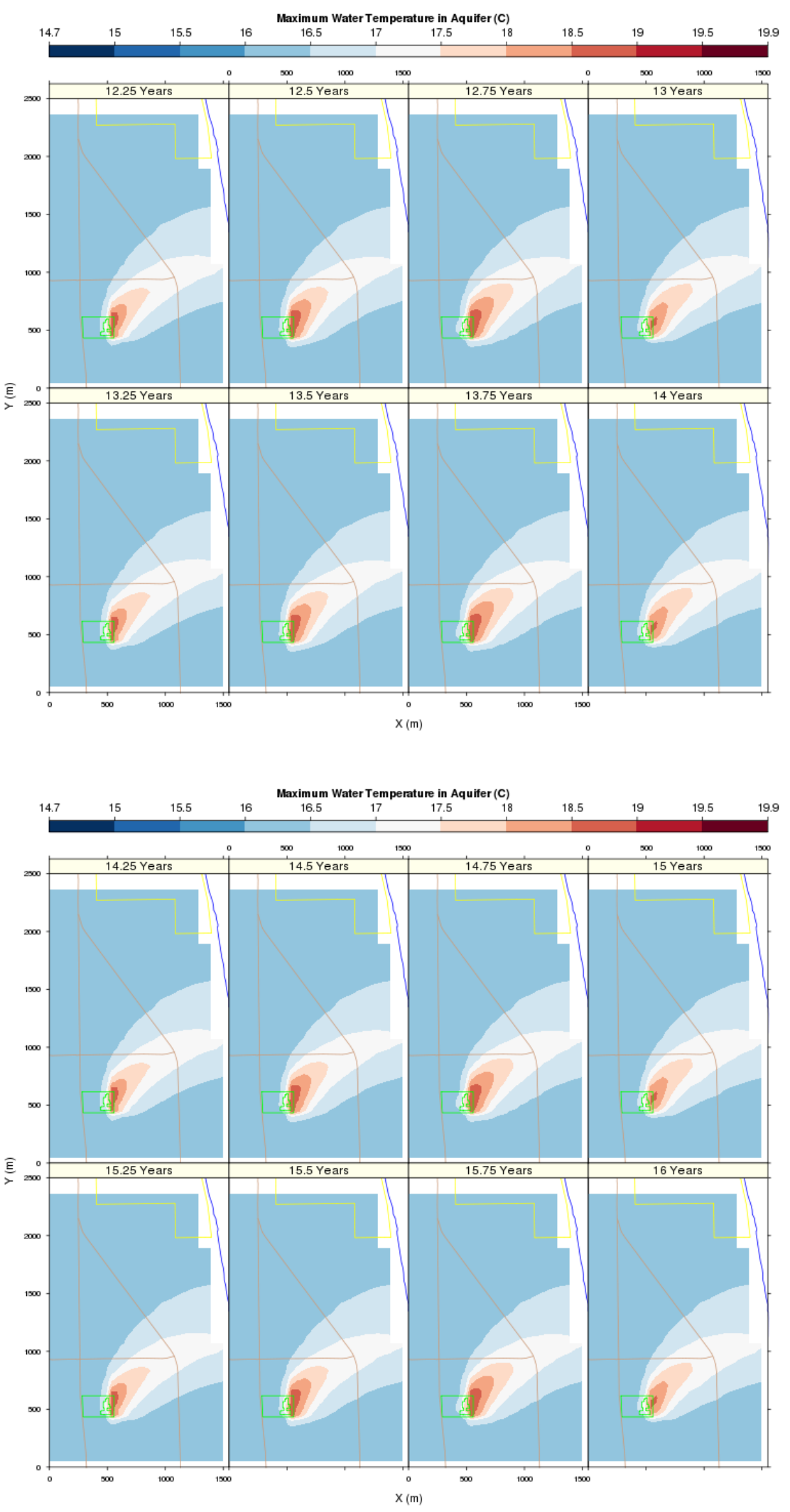

Figure E.1 (contd)

E.4 

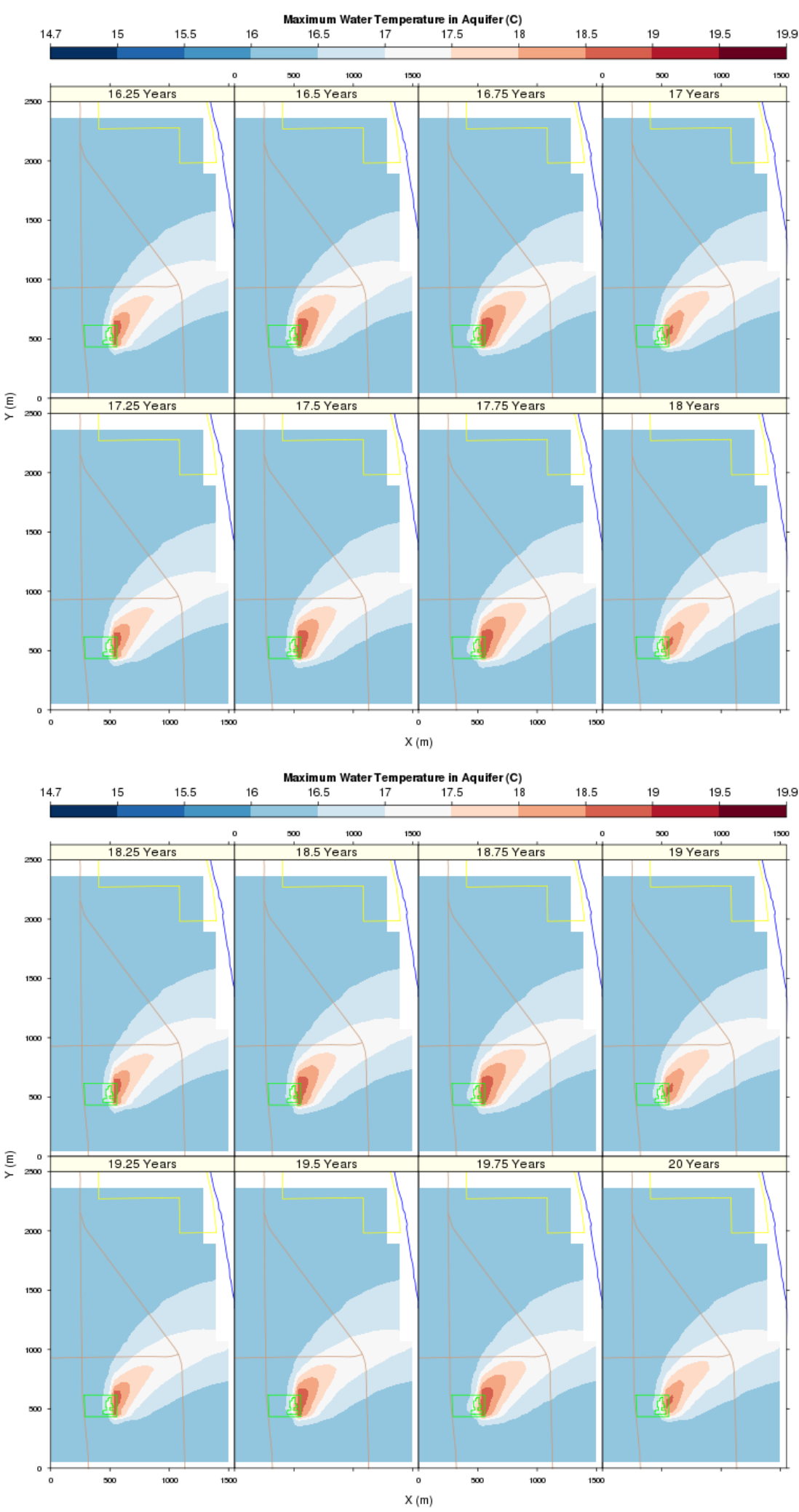

Figure E.1 (contd) 

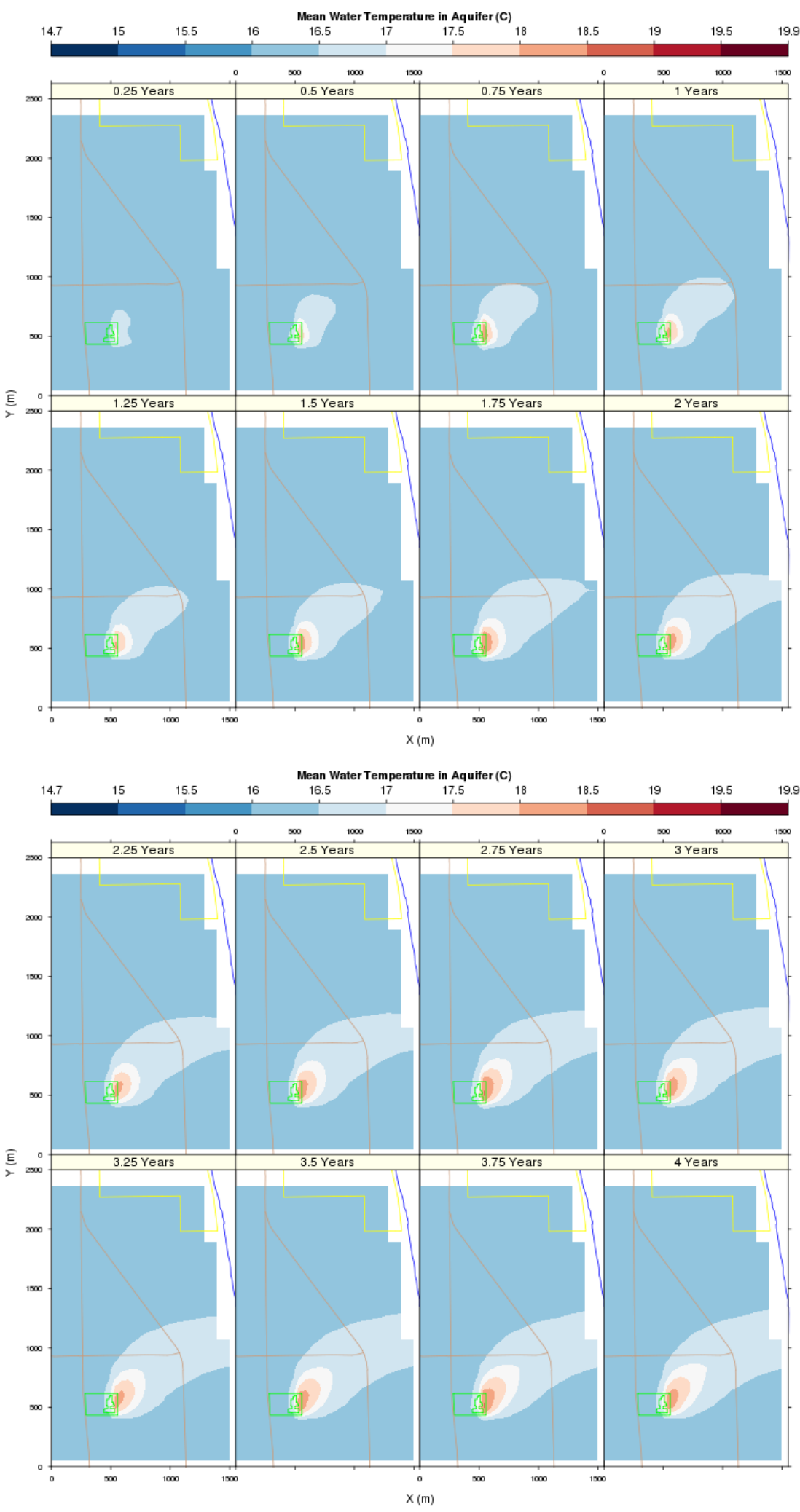

Figure E.2. Mean Temperature Distribution for Case 1c At Quarter Year Intervals 

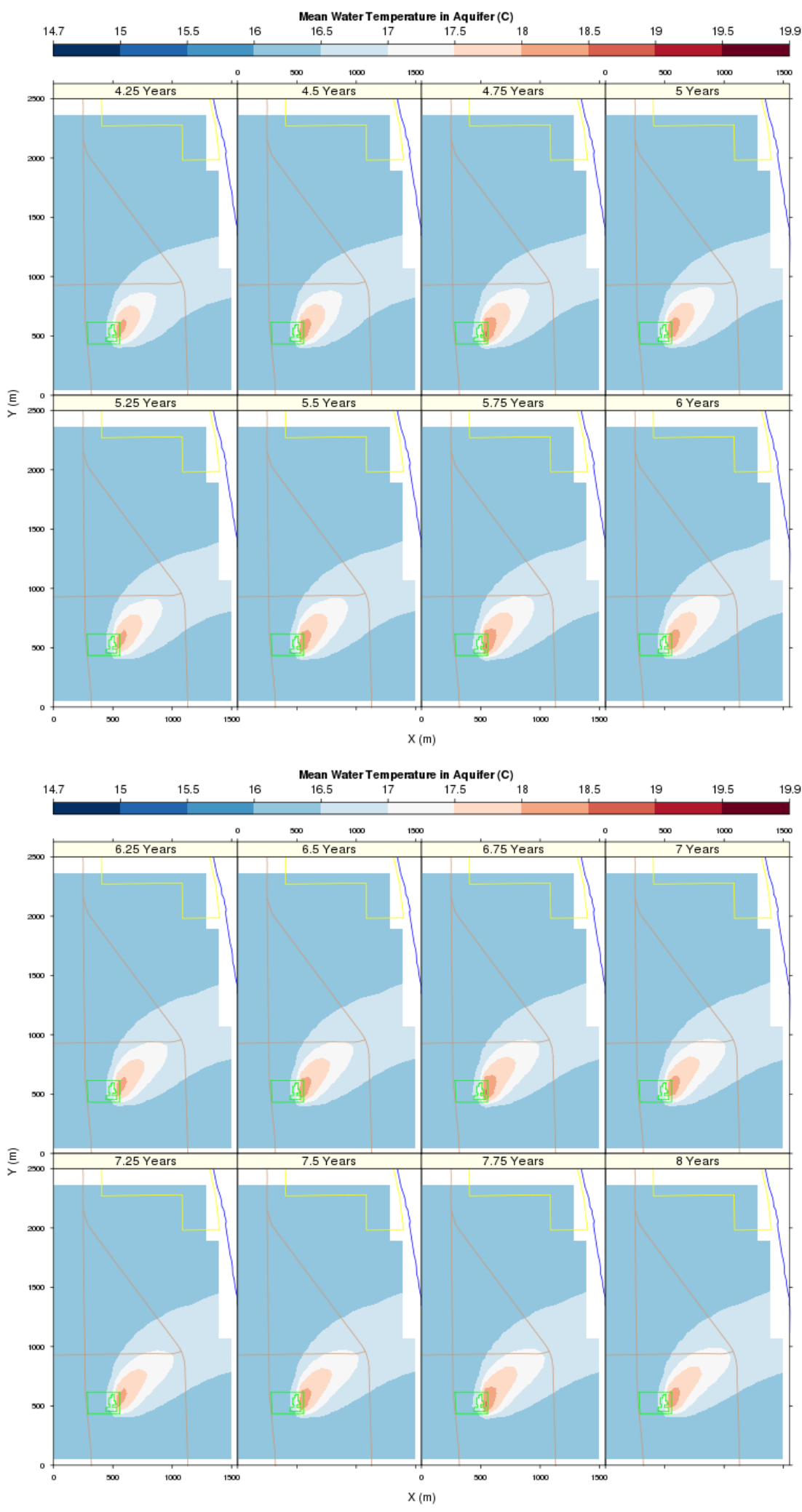

Figure E.2 (contd) 

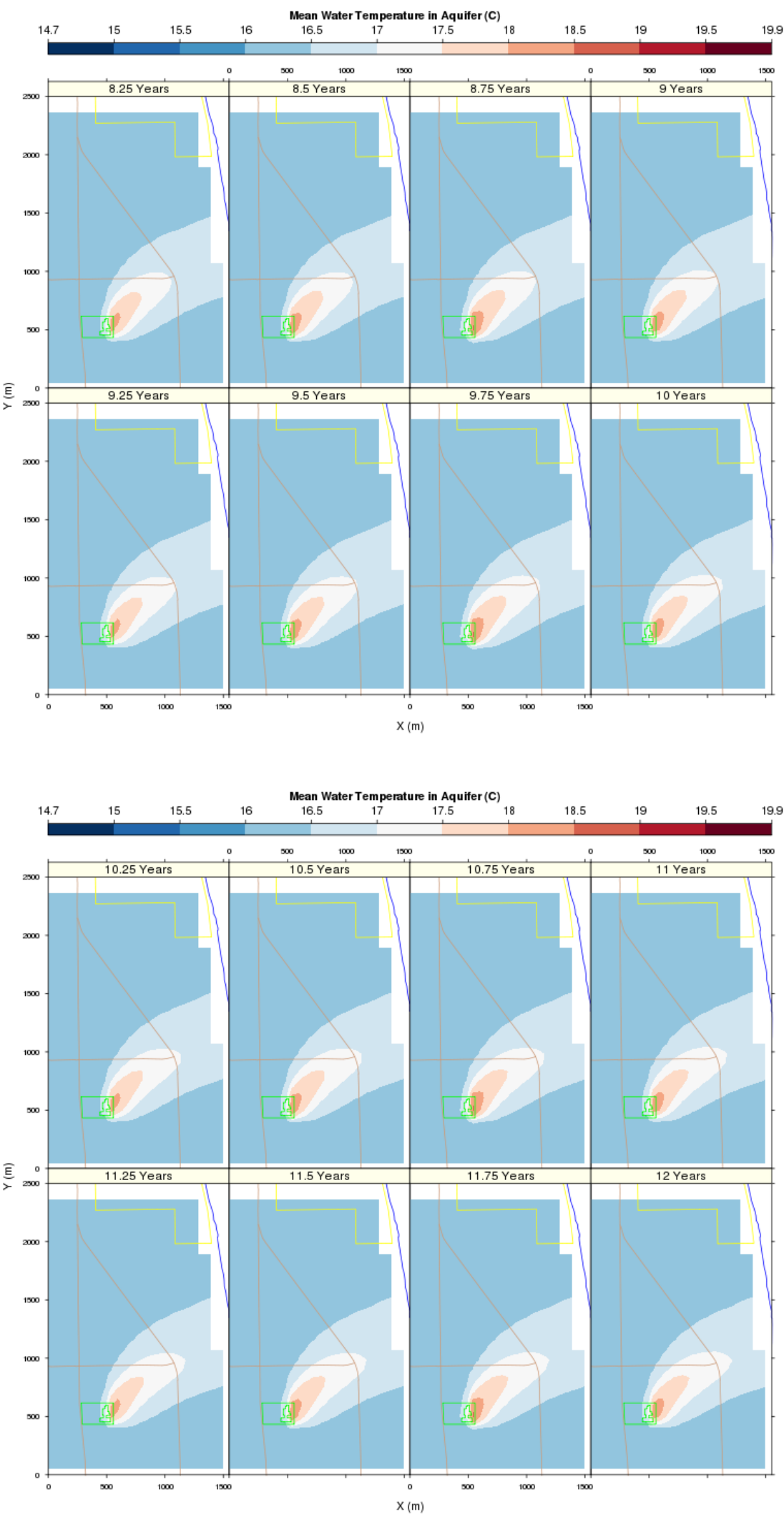

Figure E.2 (contd) 

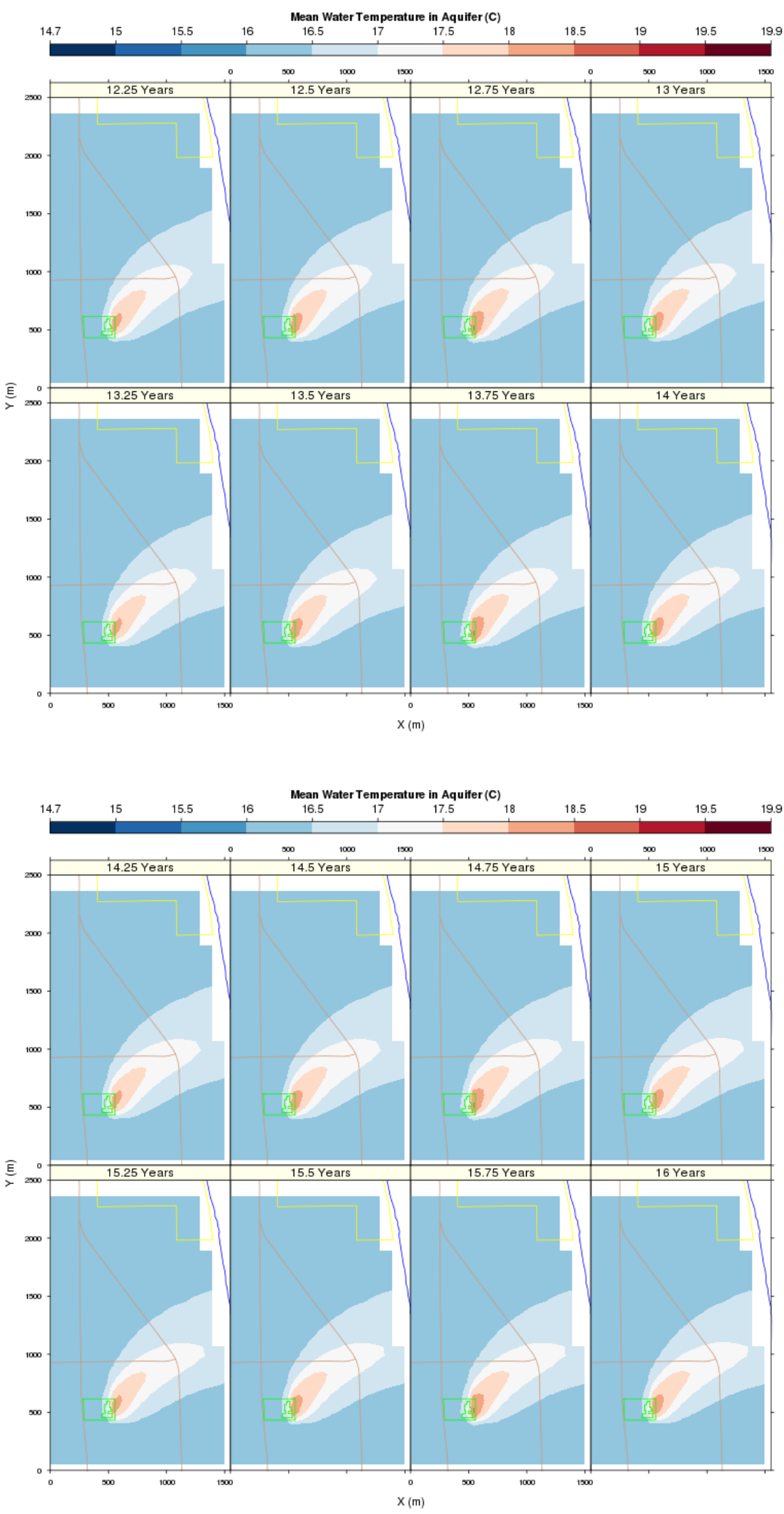

Figure E.2 (contd) 

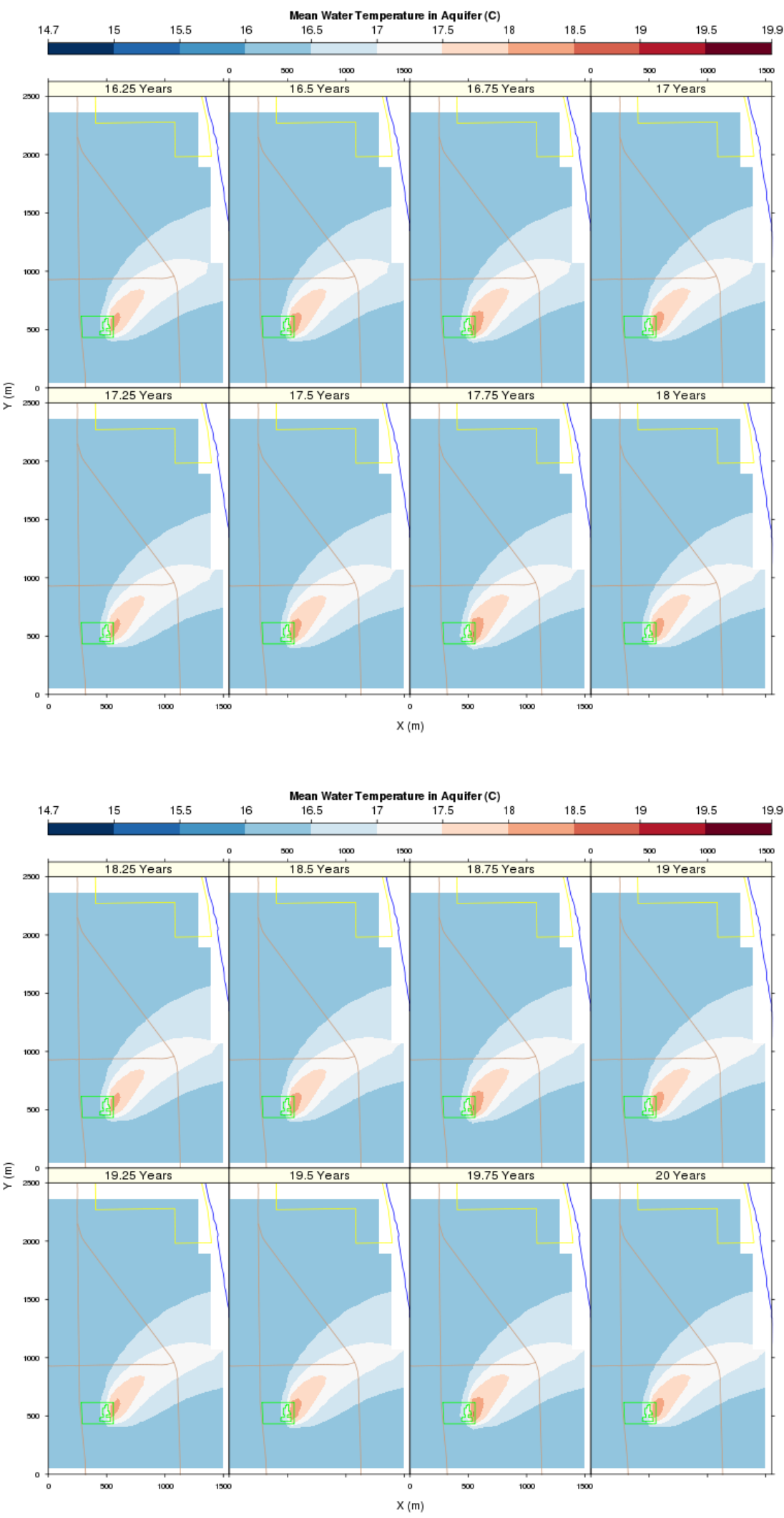

Figure E.2 (contd)

E.10 
Appendix F

\section{Heat Transport Results}

Case 1b (60 m/d Ringold Hydraulic Conductivity, Peak Scenario) 
Appendix F: Heat Transport Results:

Case 1b (60 m/d Ringold Hydraulic Conductivity, Peak Scenario) 

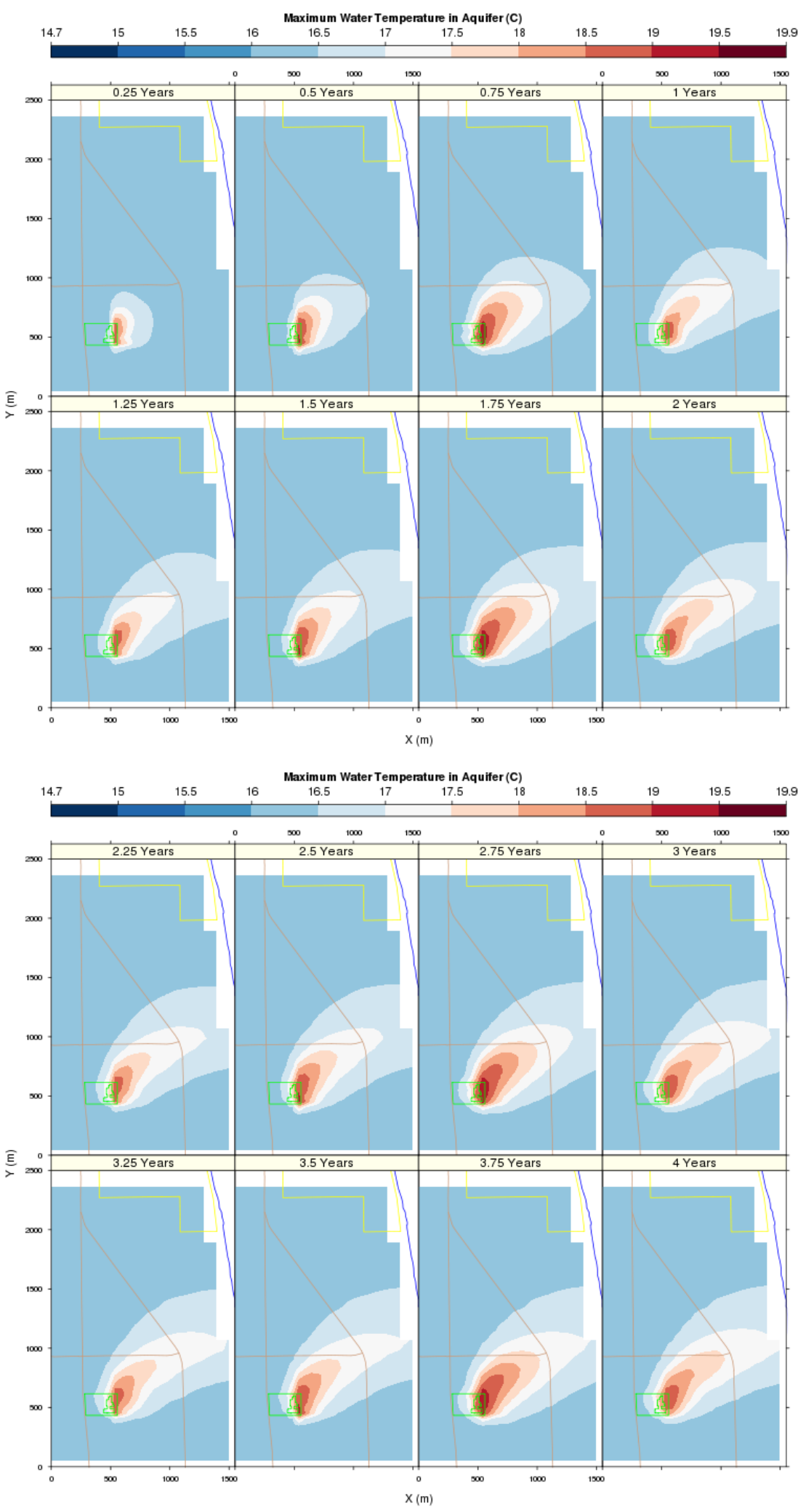

Figure F.1. Maximum Temperature Distribution for Case 1b At Quarter Year Intervals 

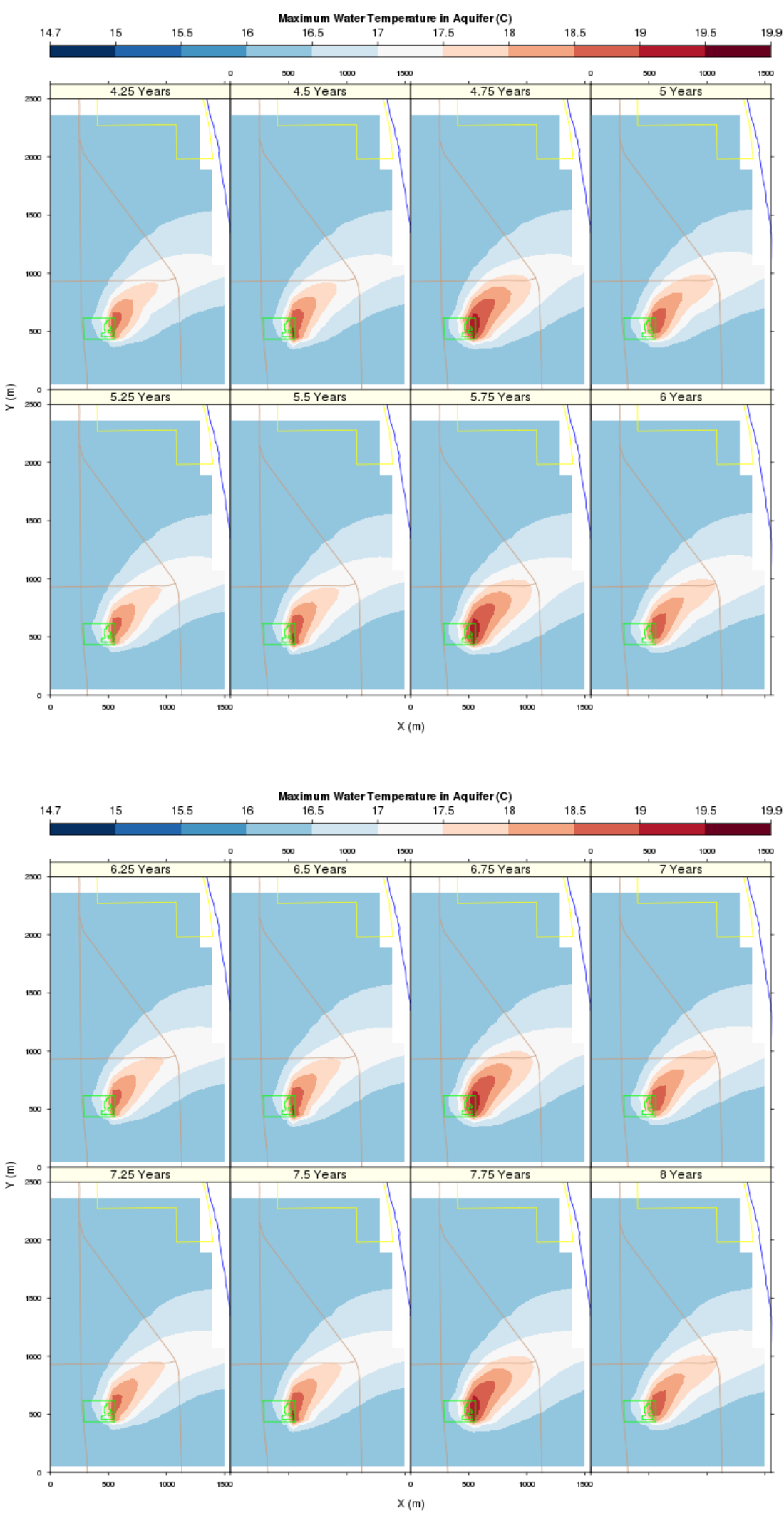

Figure F.1 (contd) 

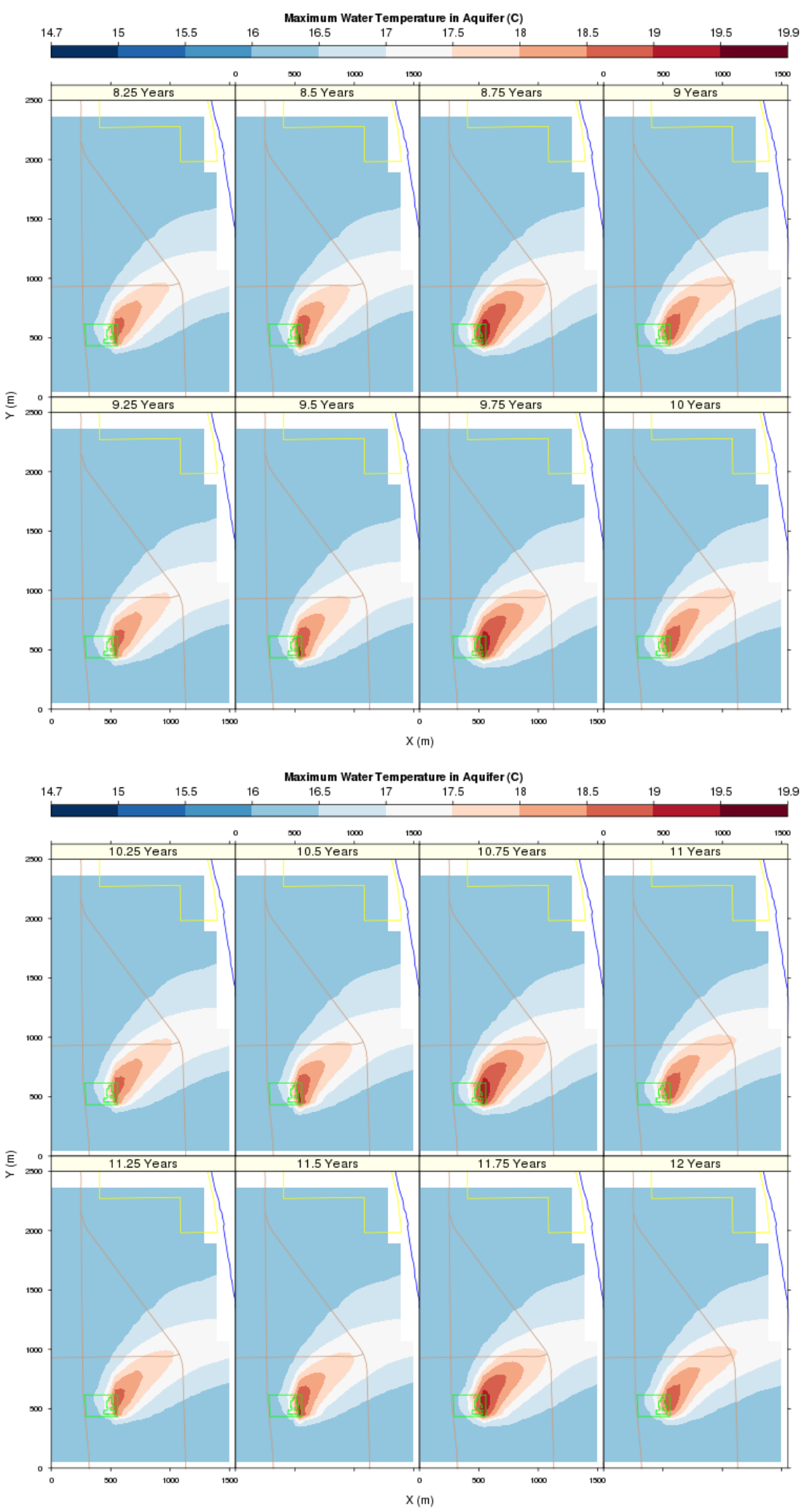

Figure F.1 (contd) 

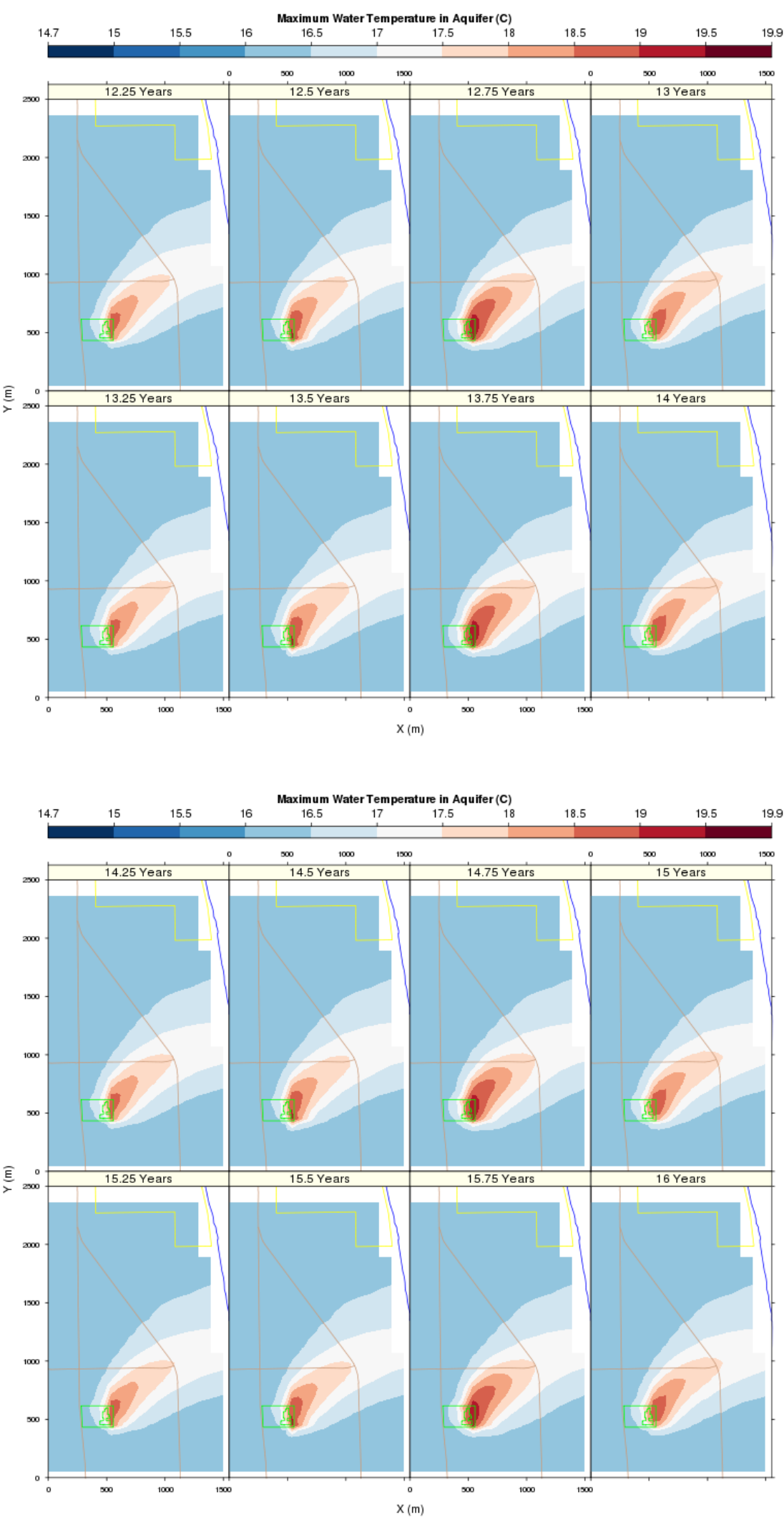

Figure F.1 (contd) 

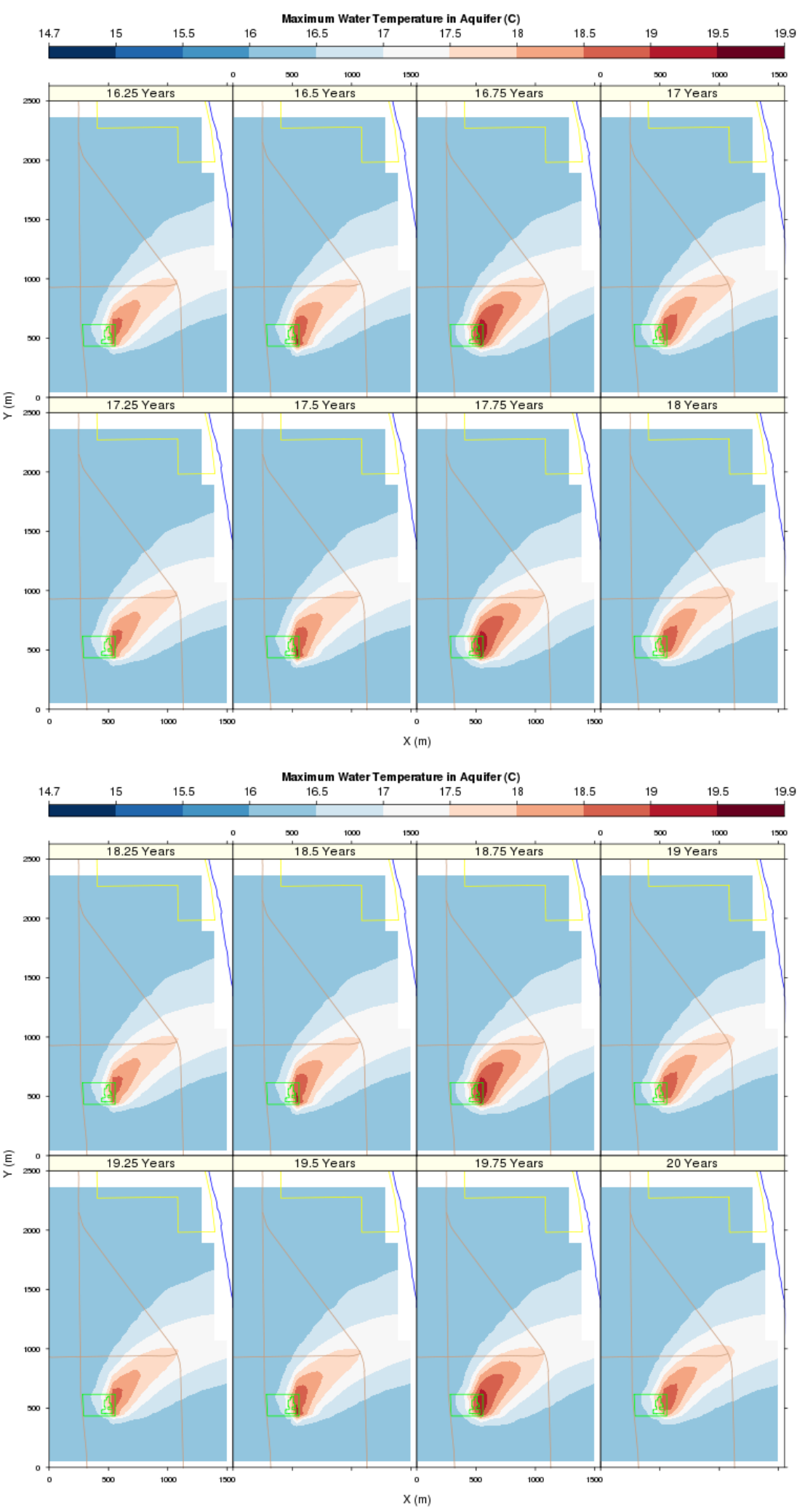

Figure F.1 (contd) 

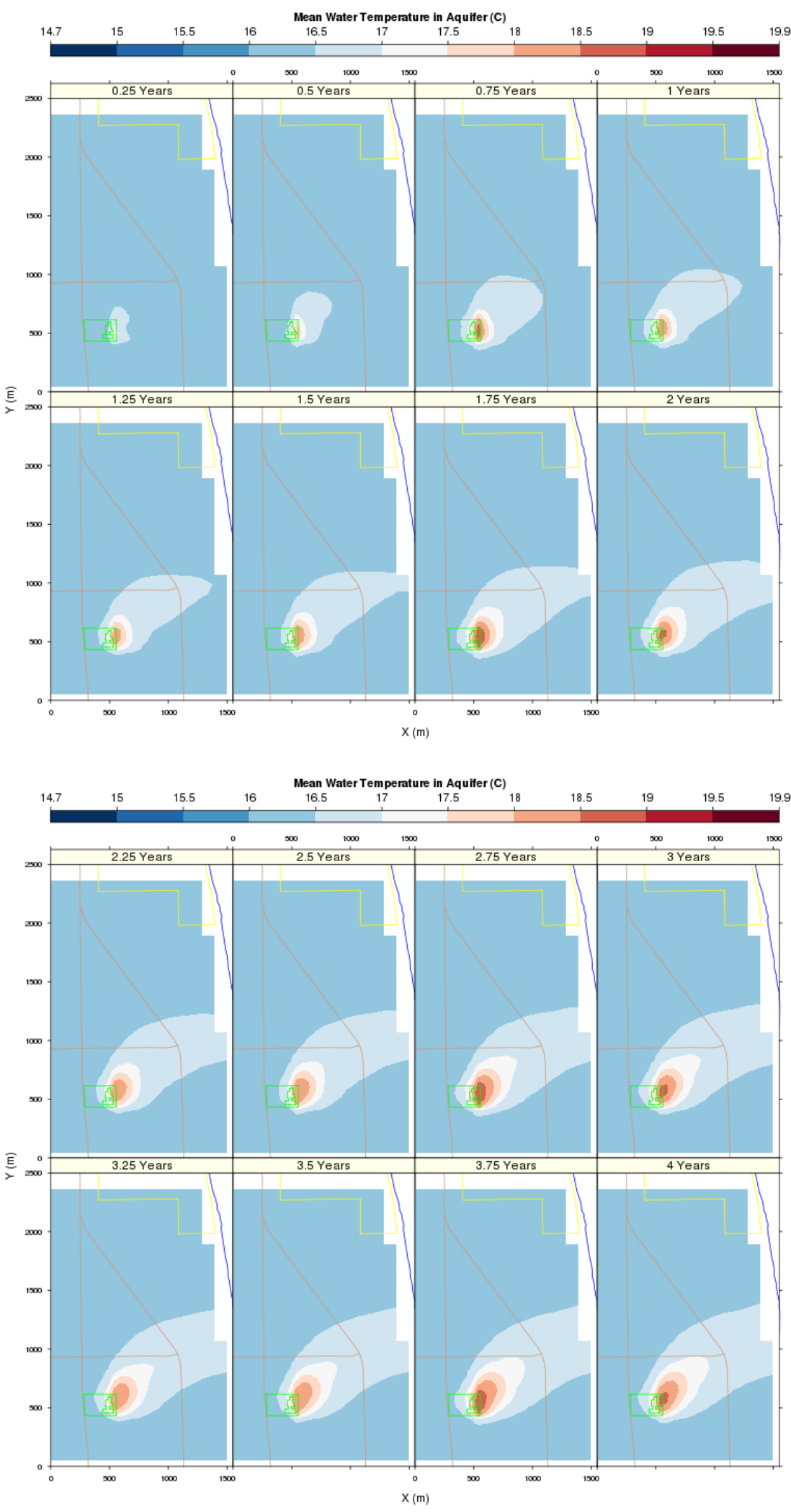

Figure F.2. Mean Temperature Distribution for Case 1b At Quarter Year Intervals 

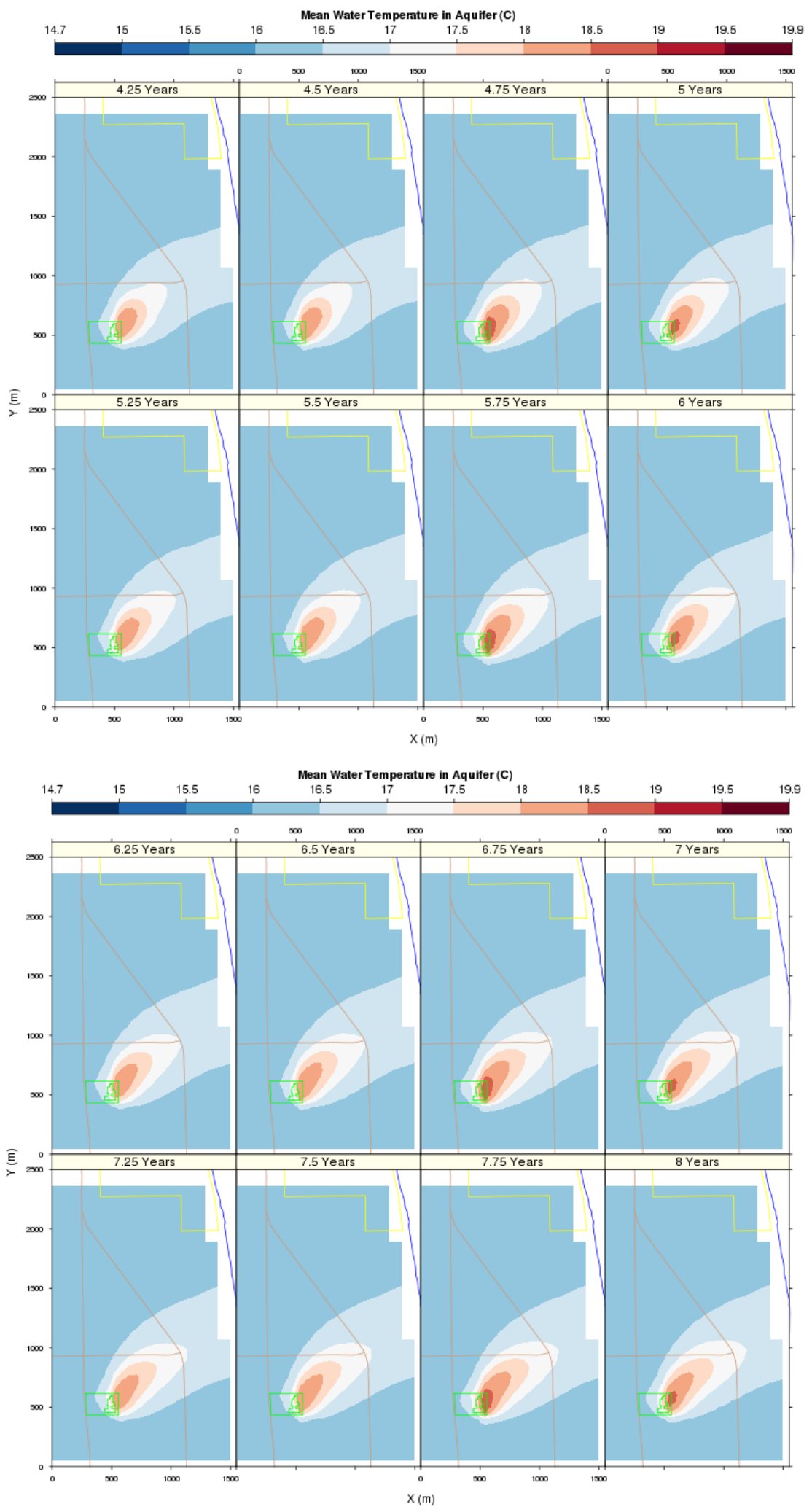

Figure F.2 (contd) 

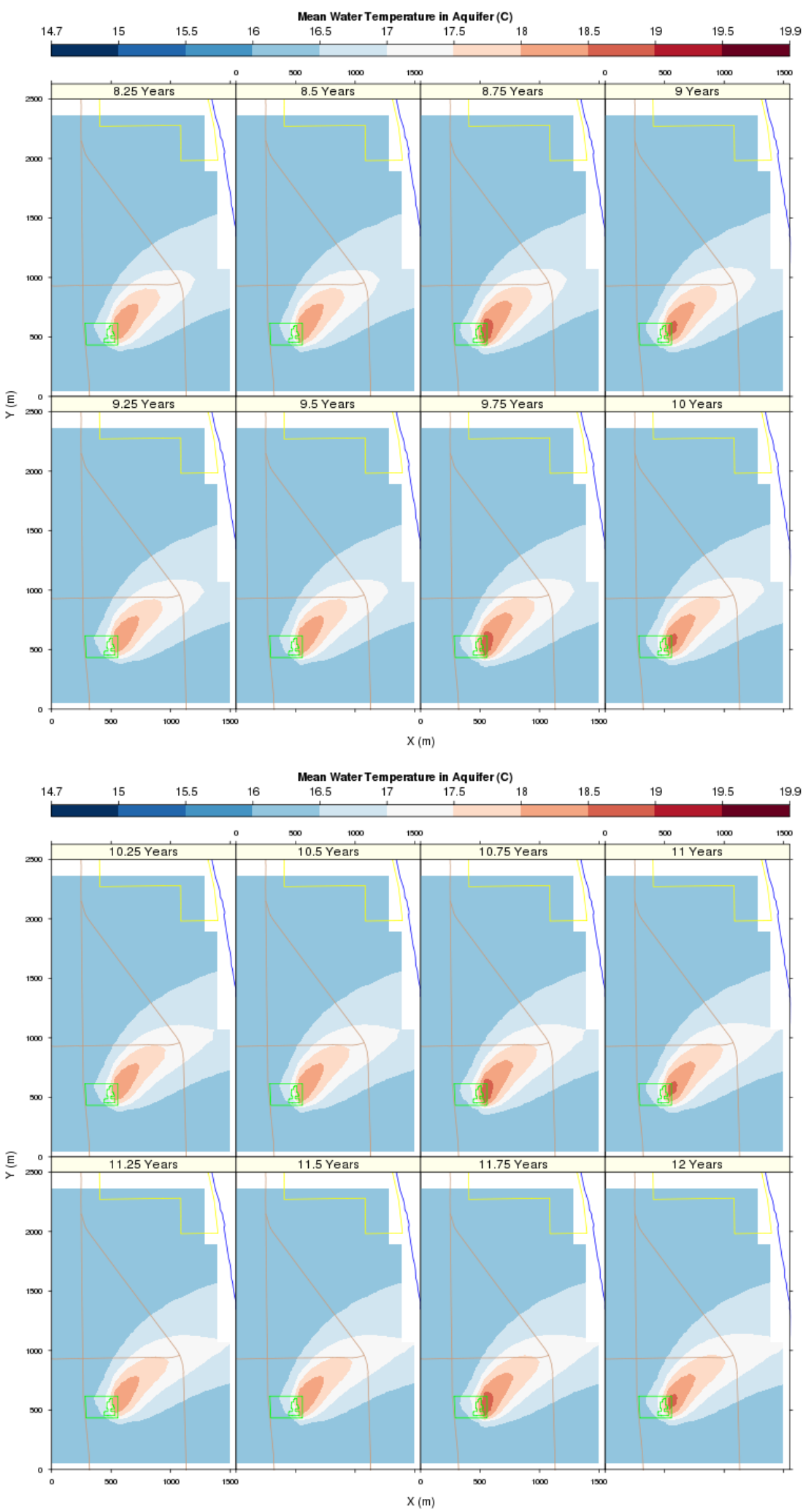

Figure F.2 (contd) 

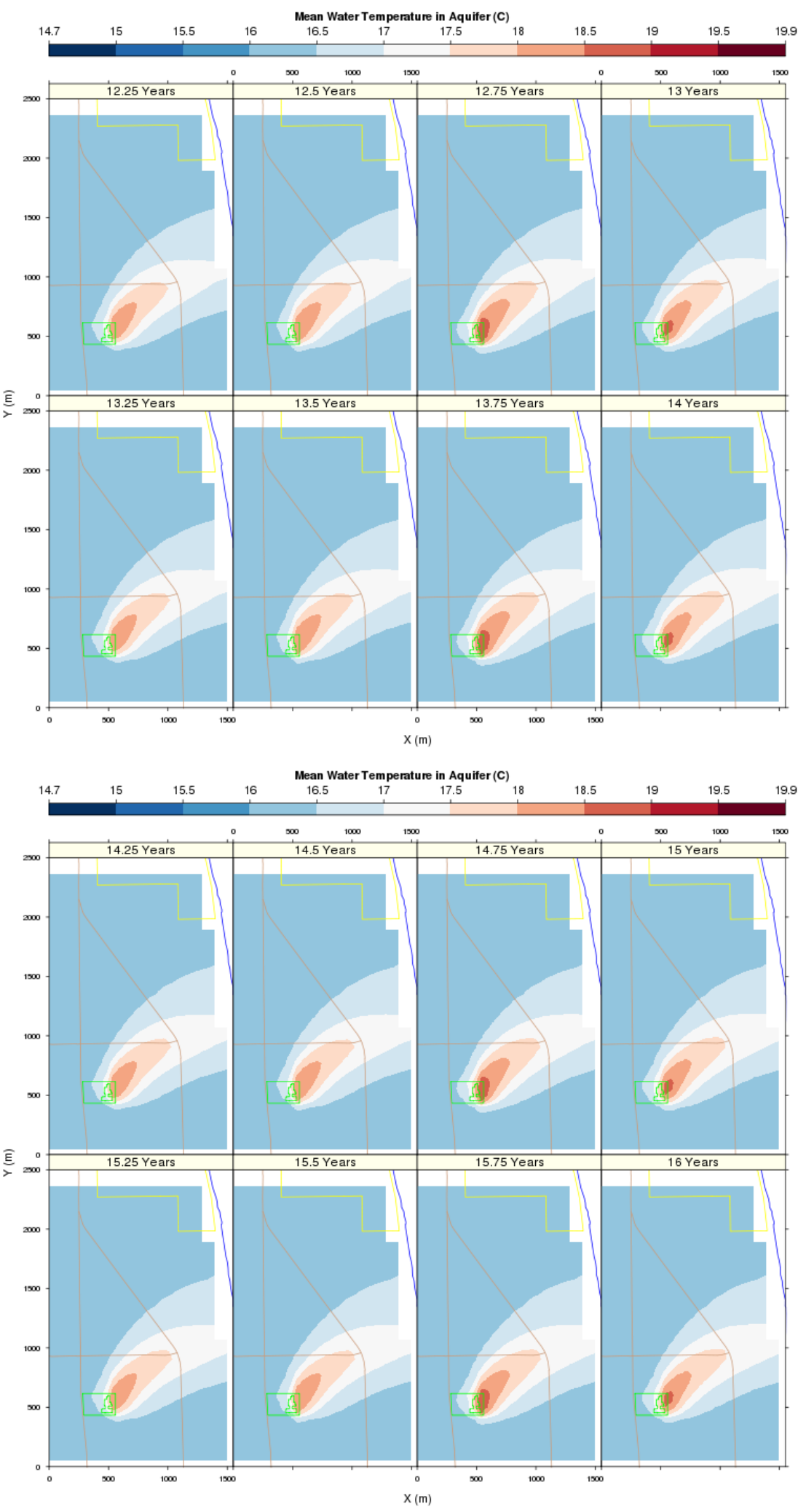

Figure F.2 (contd) 

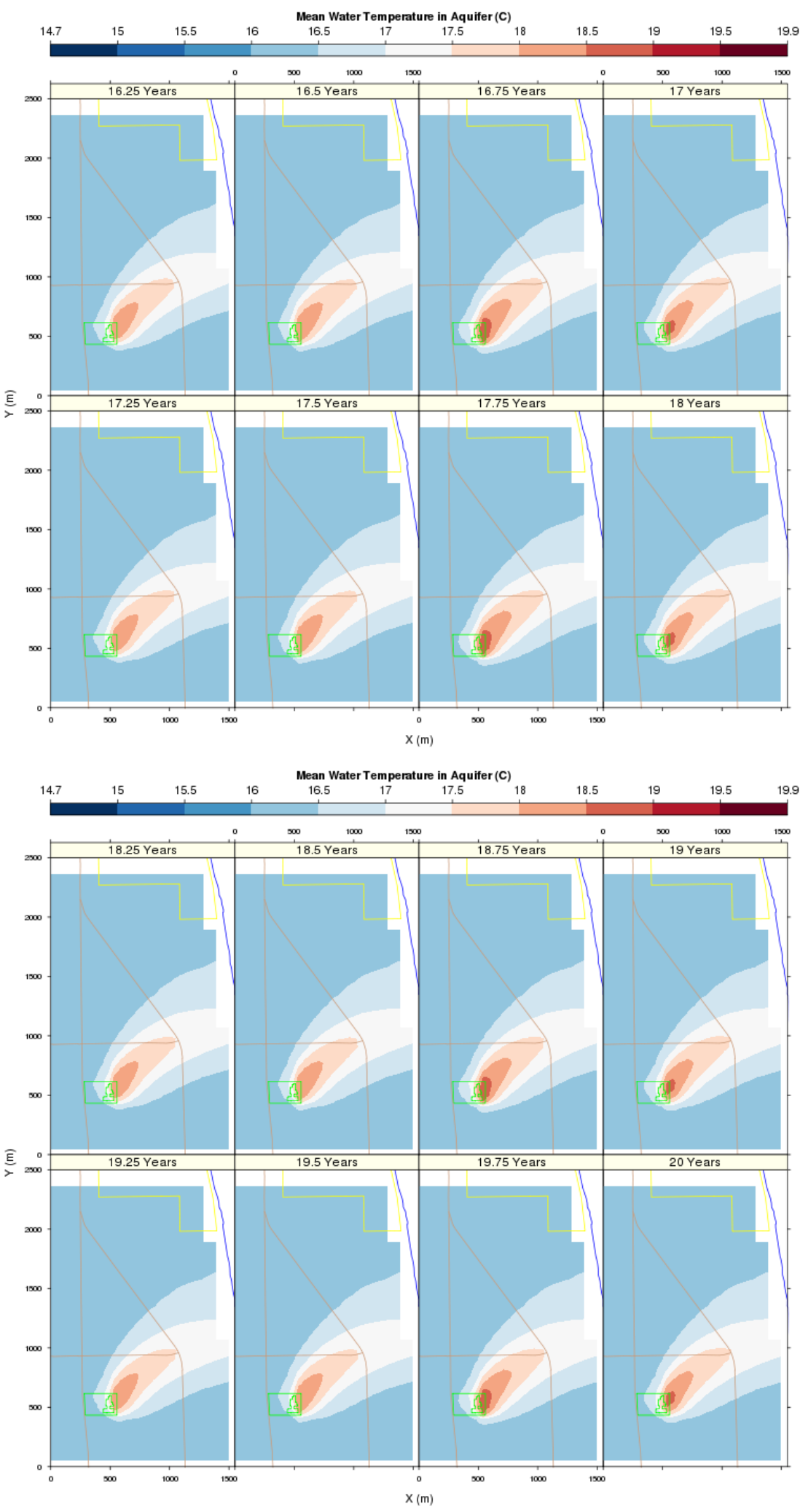

Figure F.2 (contd) 
Appendix G

\section{Heat Transport Results}

Case 2a (150 m/d Ringold Hydraulic Conductivity, Average Scenario) 


\section{Appendix G: Heat Transport Results}

Case 2a (150 m/d Ringold Hydraulic Conductivity, Average Scenario)
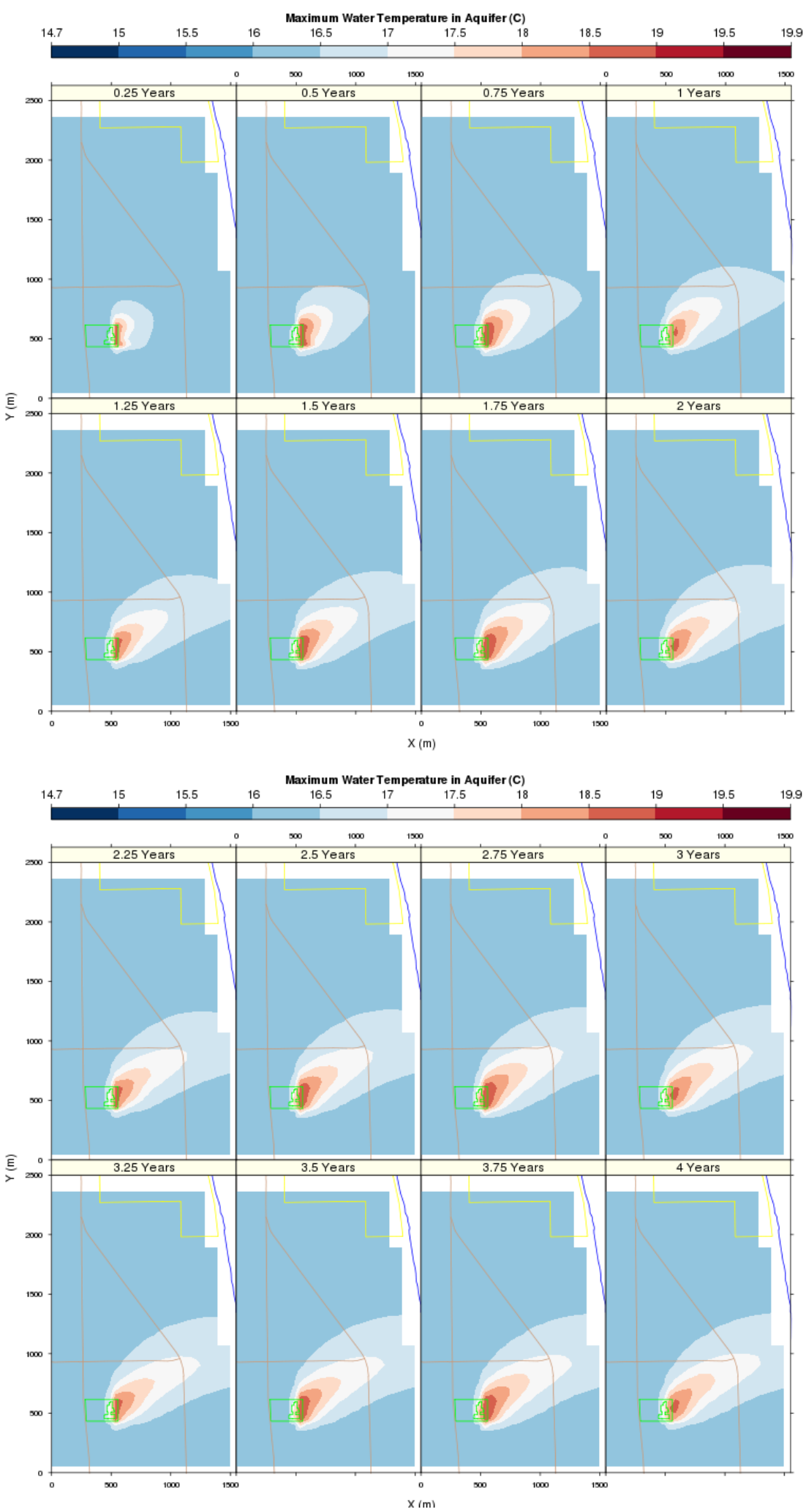

Figure G.1. Maximum Temperature Distribution for Case 2a At Quarter Year Intervals G.1 

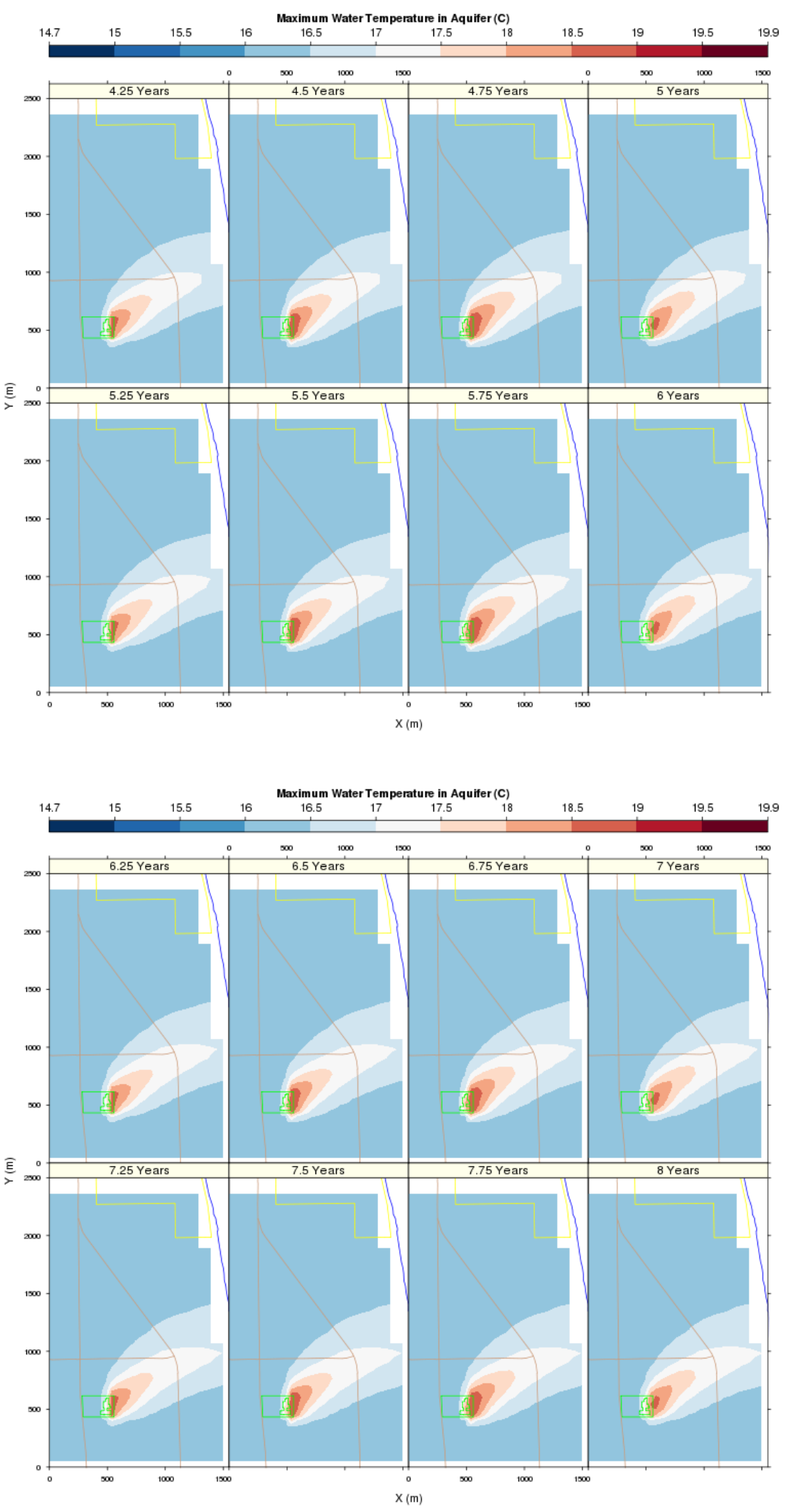

Figure G.1 (contd)

G.2 

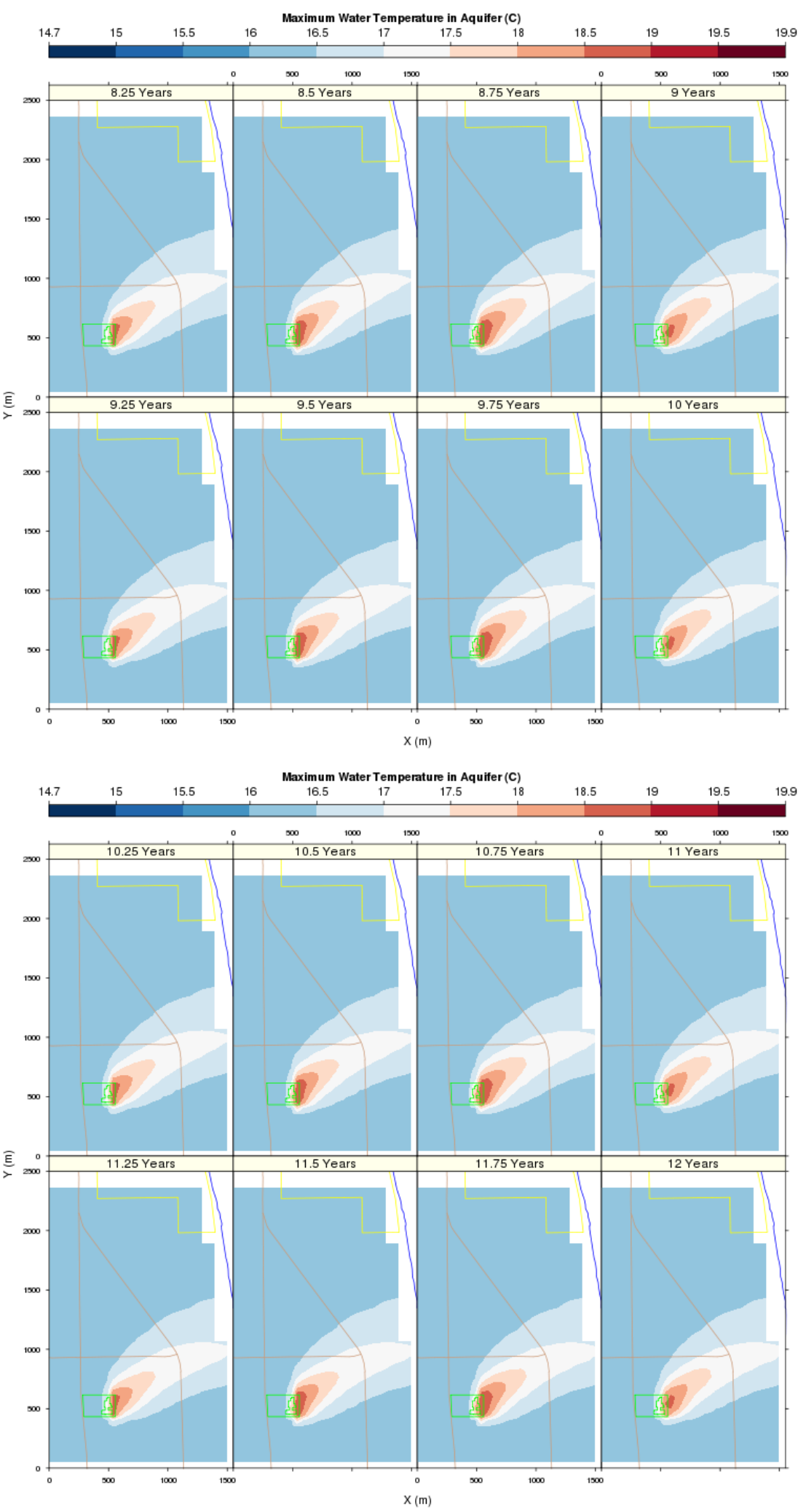

Figure G.1 (contd) 

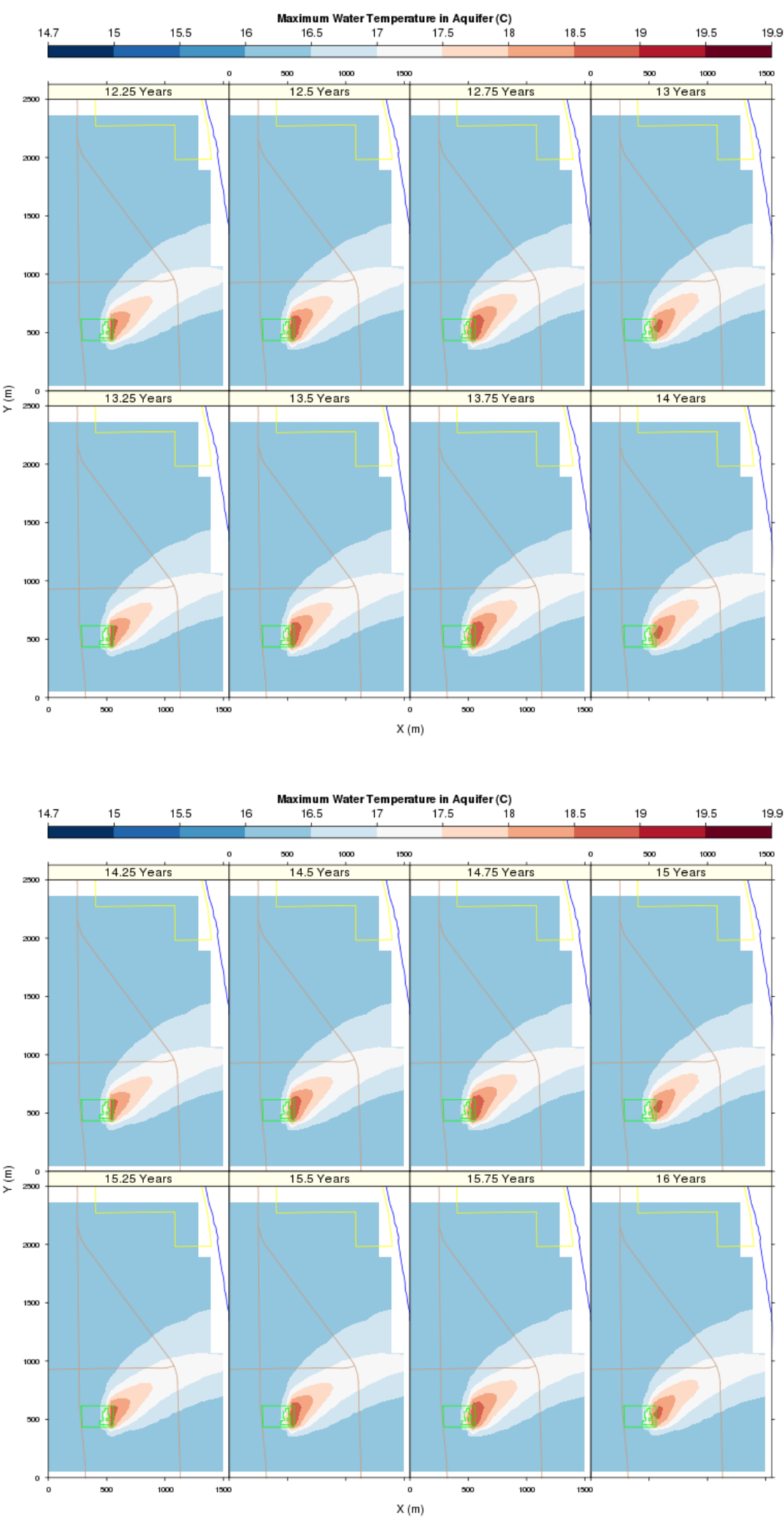

Figure G.1 (contd) 

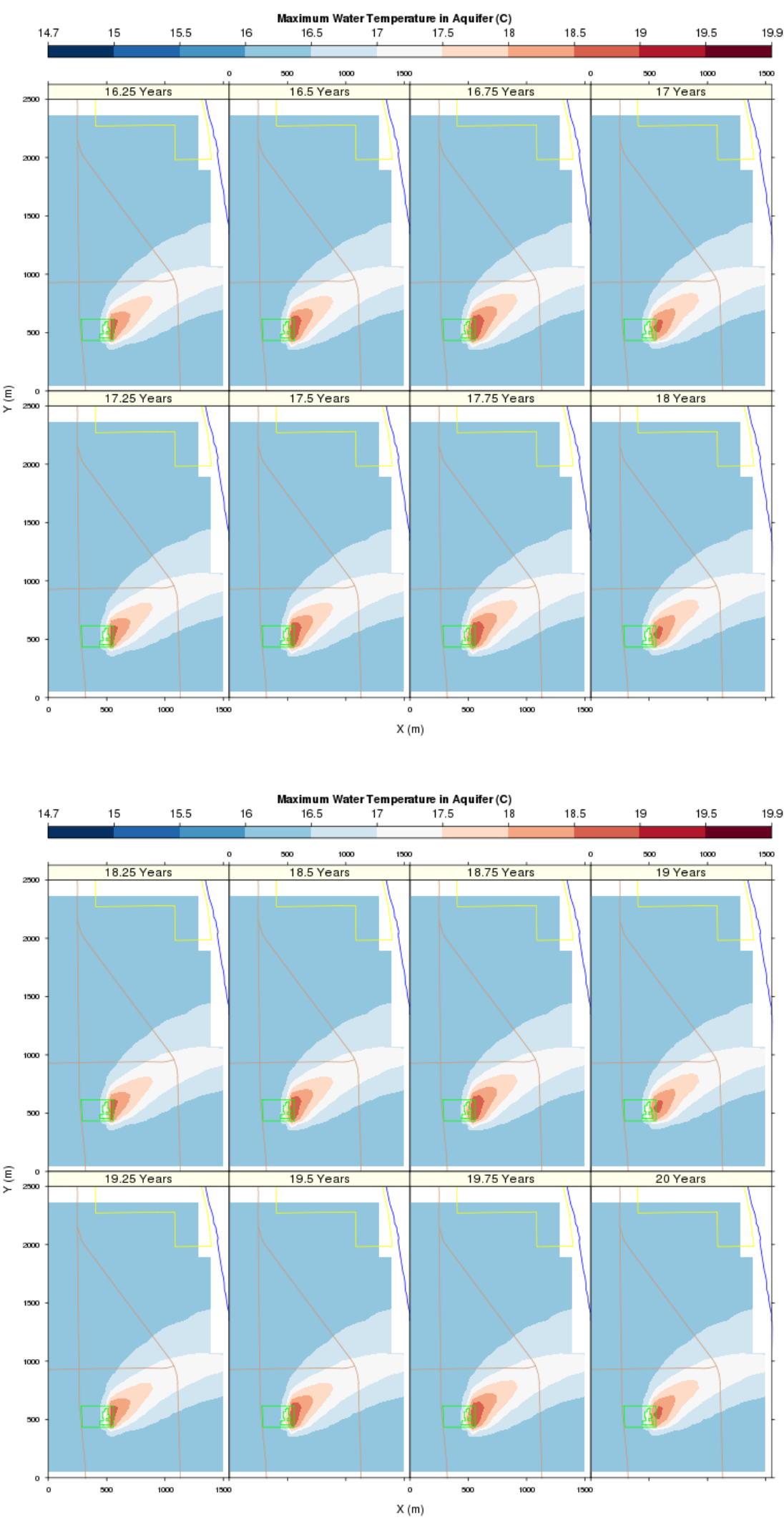

Figure G.1 (contd)

G.5 

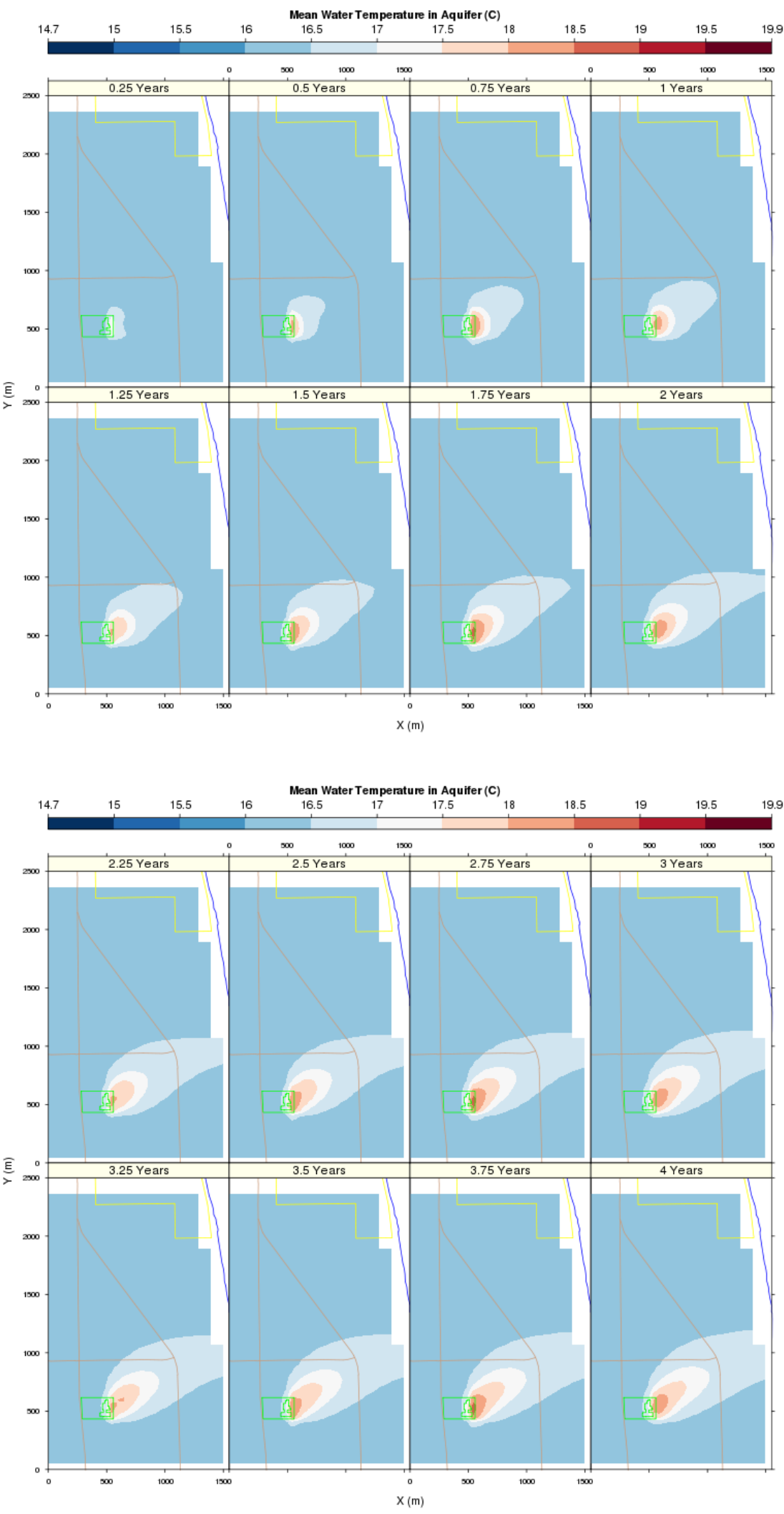

Figure G.2. Mean Temperature Distribution for Case 2a At Quarter Year Intervals 

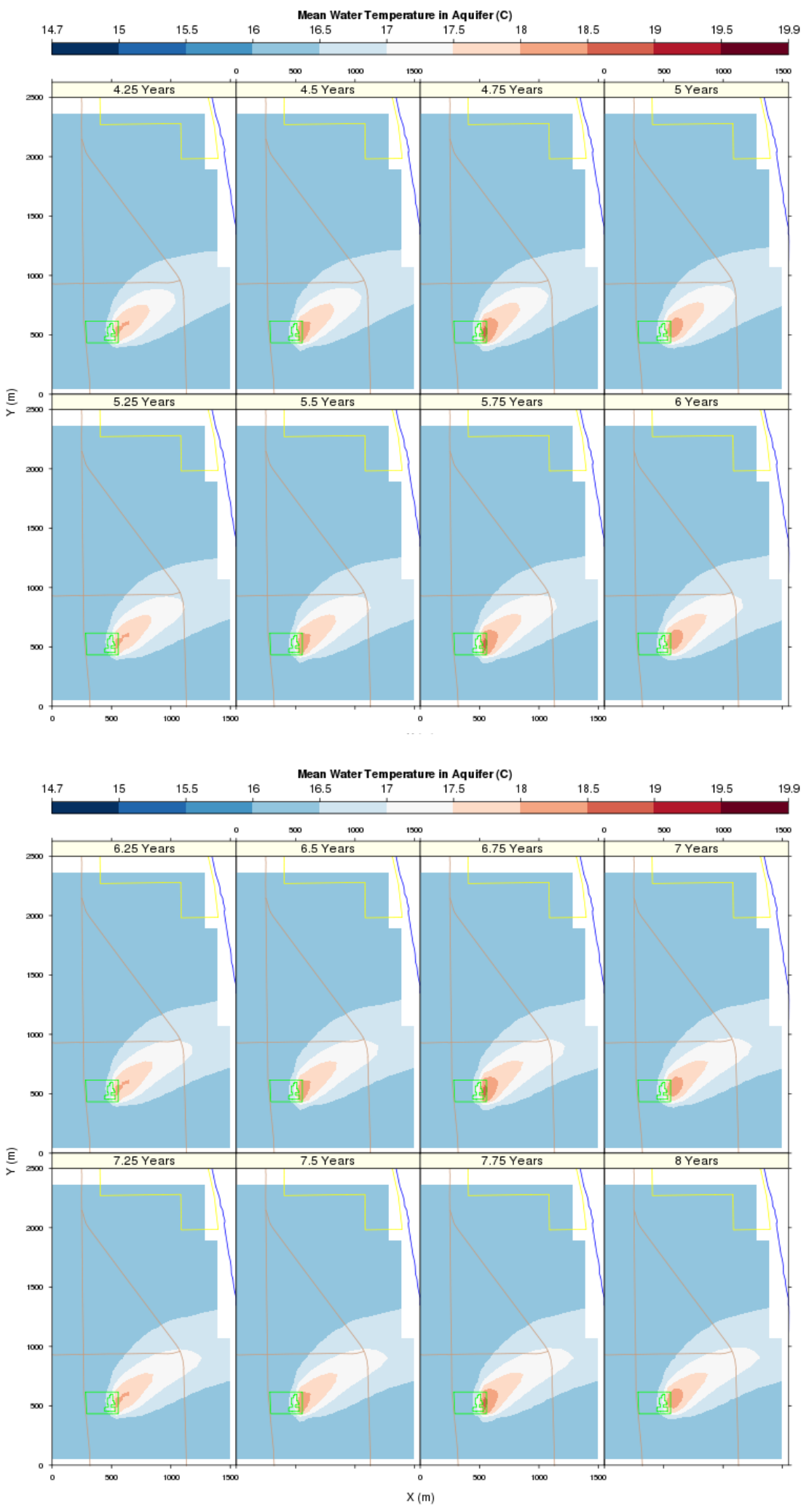

Figure G.2 (contd) 

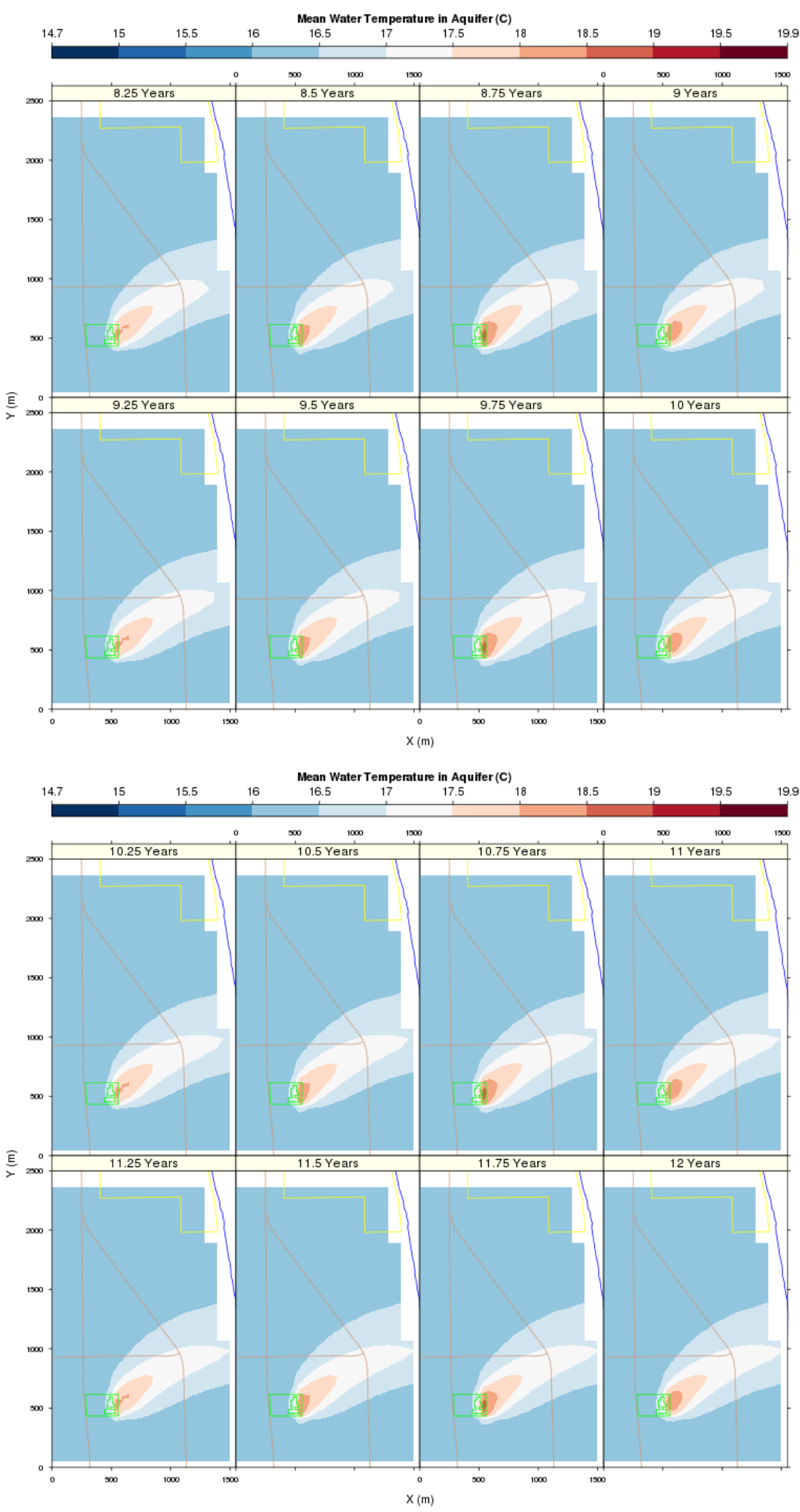

Figure G.2 (contd) 

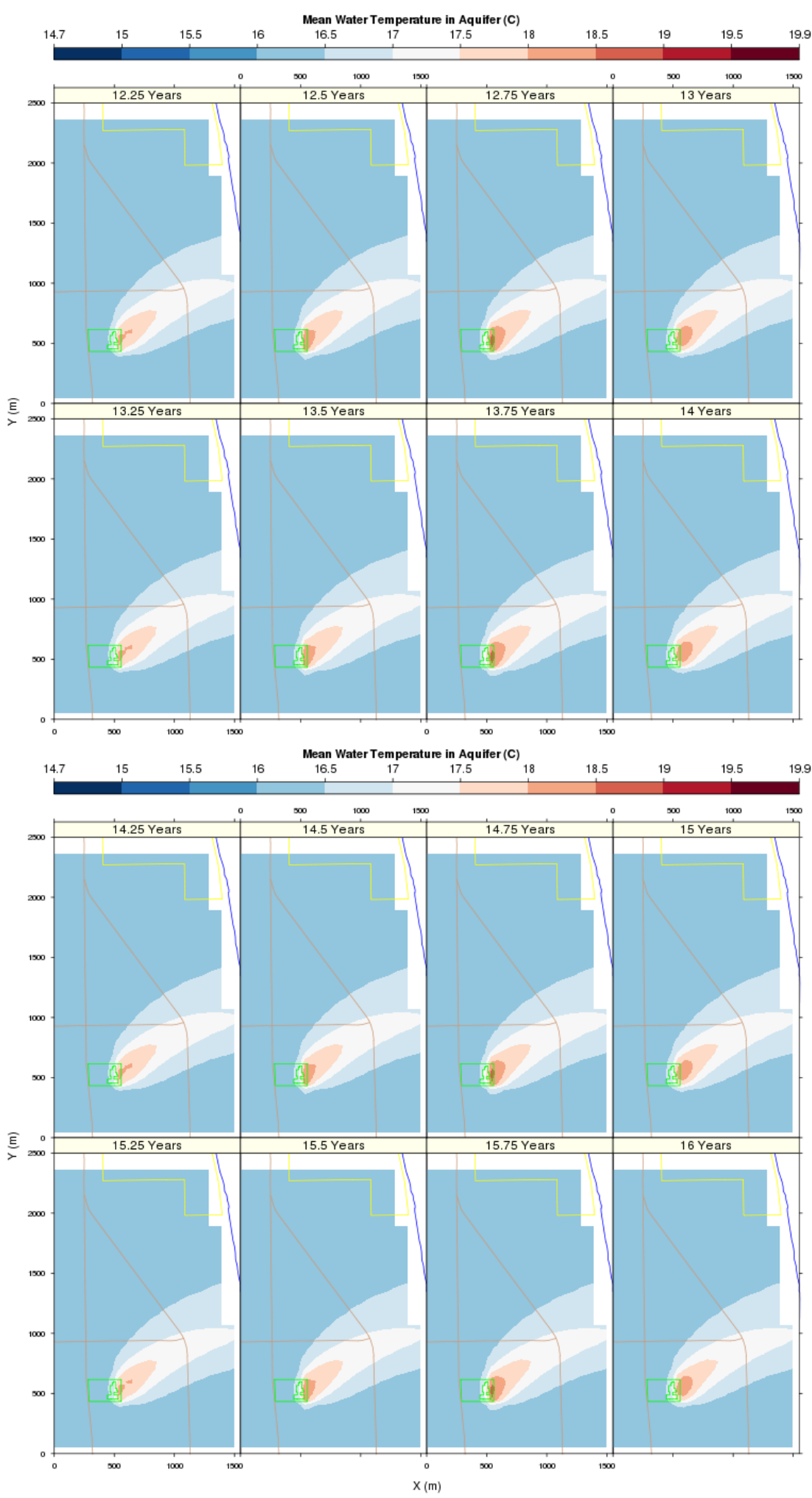

Figure G.2 (contd) 

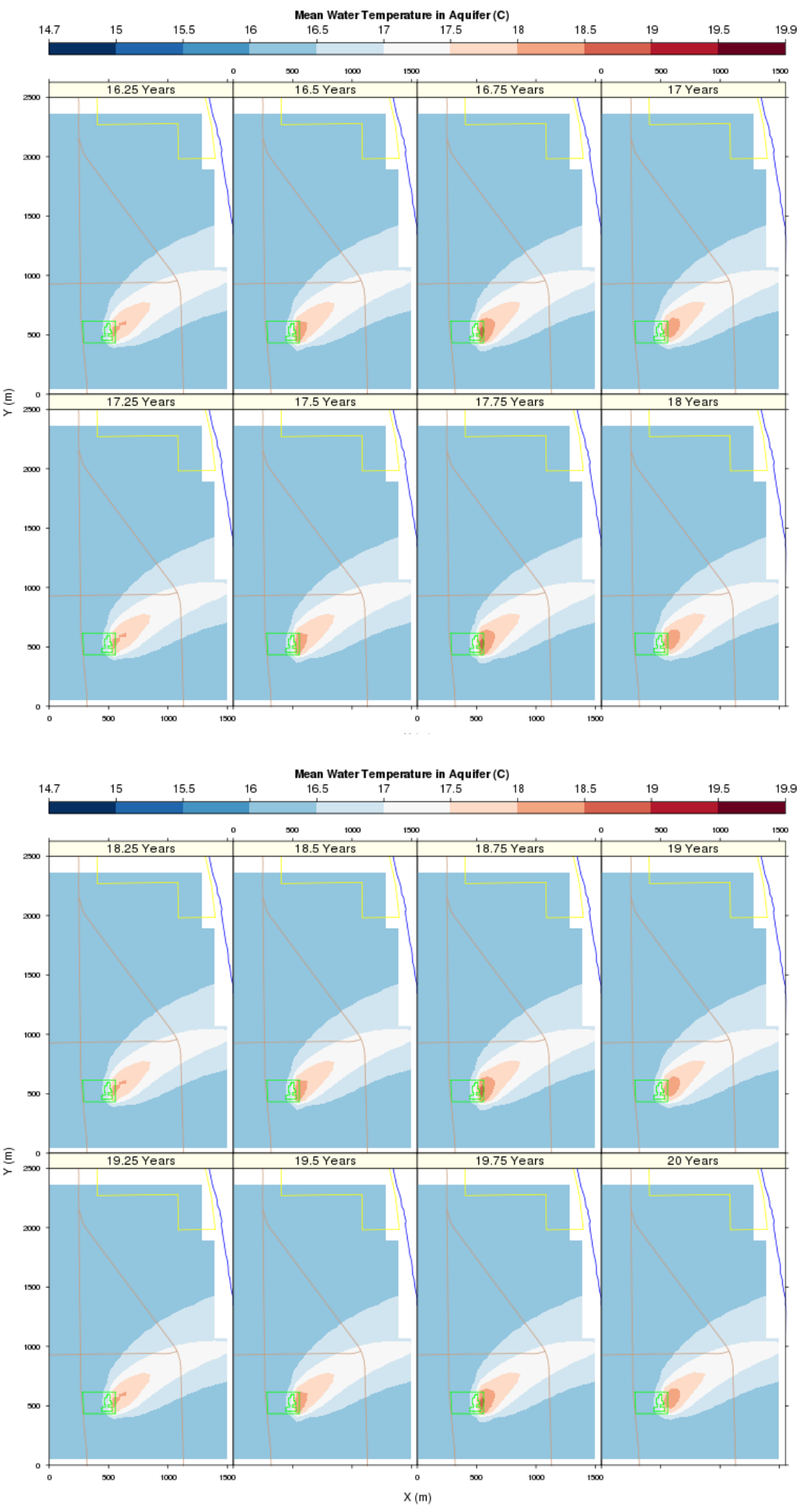

Figure G.2 (contd)

\section{G.10}




\section{Appendix $\mathrm{H}$}

\section{Heat Transport Results}

Case 2b (150 m/d Ringold Hydraulic Conductivity, Peak Scenario) 
Appendix H: Heat Transport Results Case $2 b$ (150 m/d Ringold Hydraulic Conductivity, Peak Scenario)
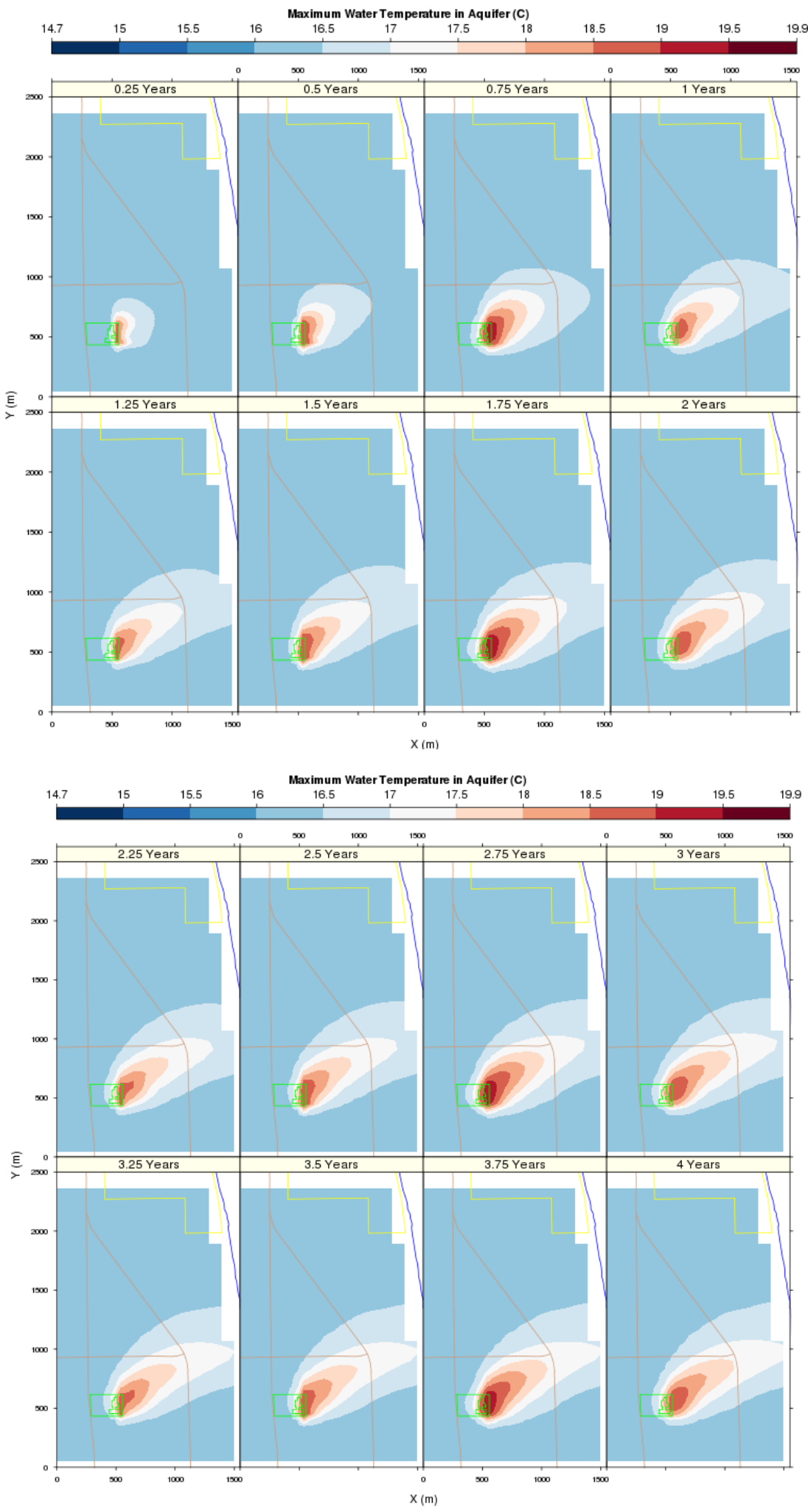

Figure H.1. Maximum Temperature Distribution for Case 2b At Quarter Year Intervals 

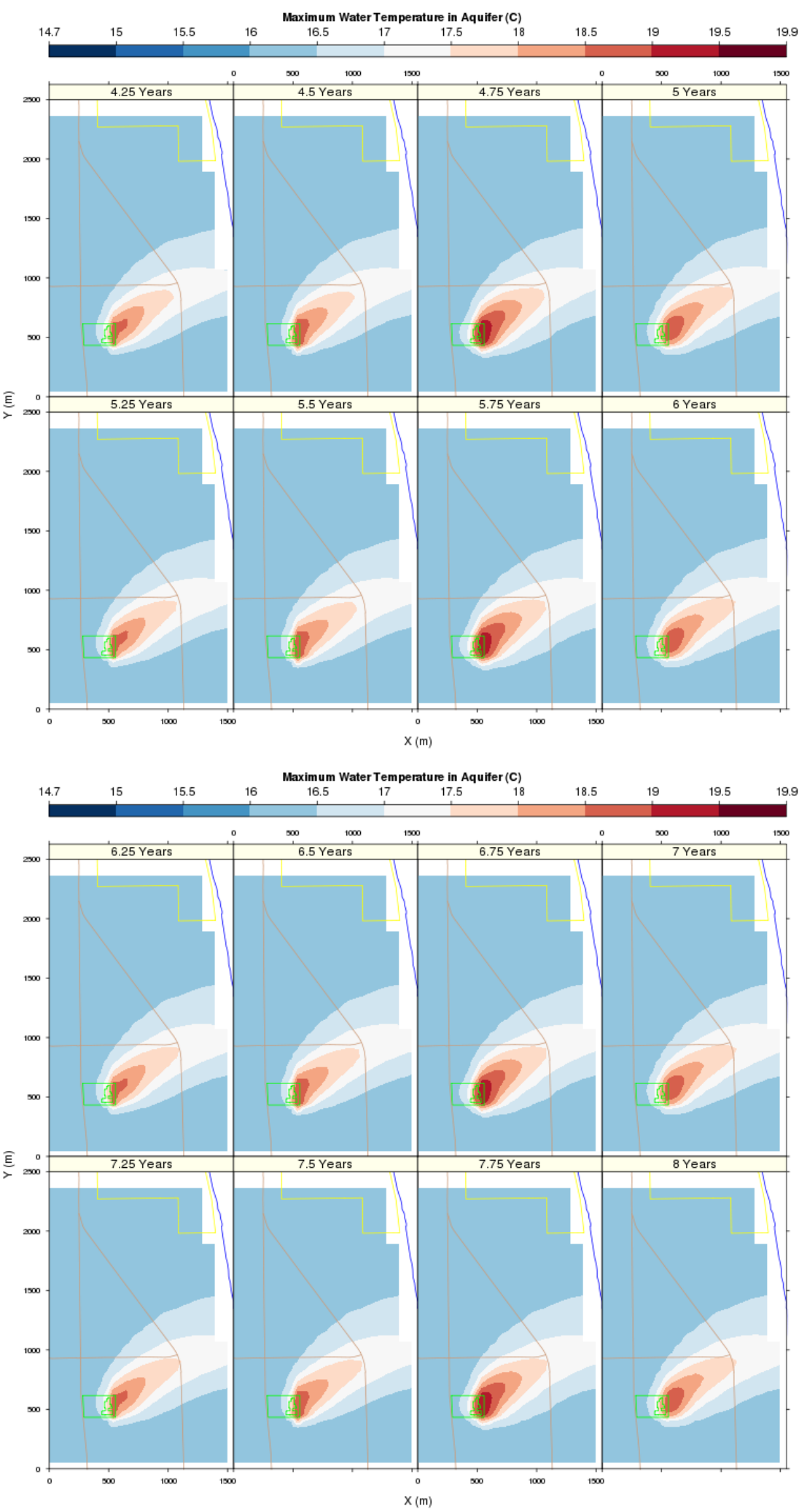

Figure H.1 (contd) 

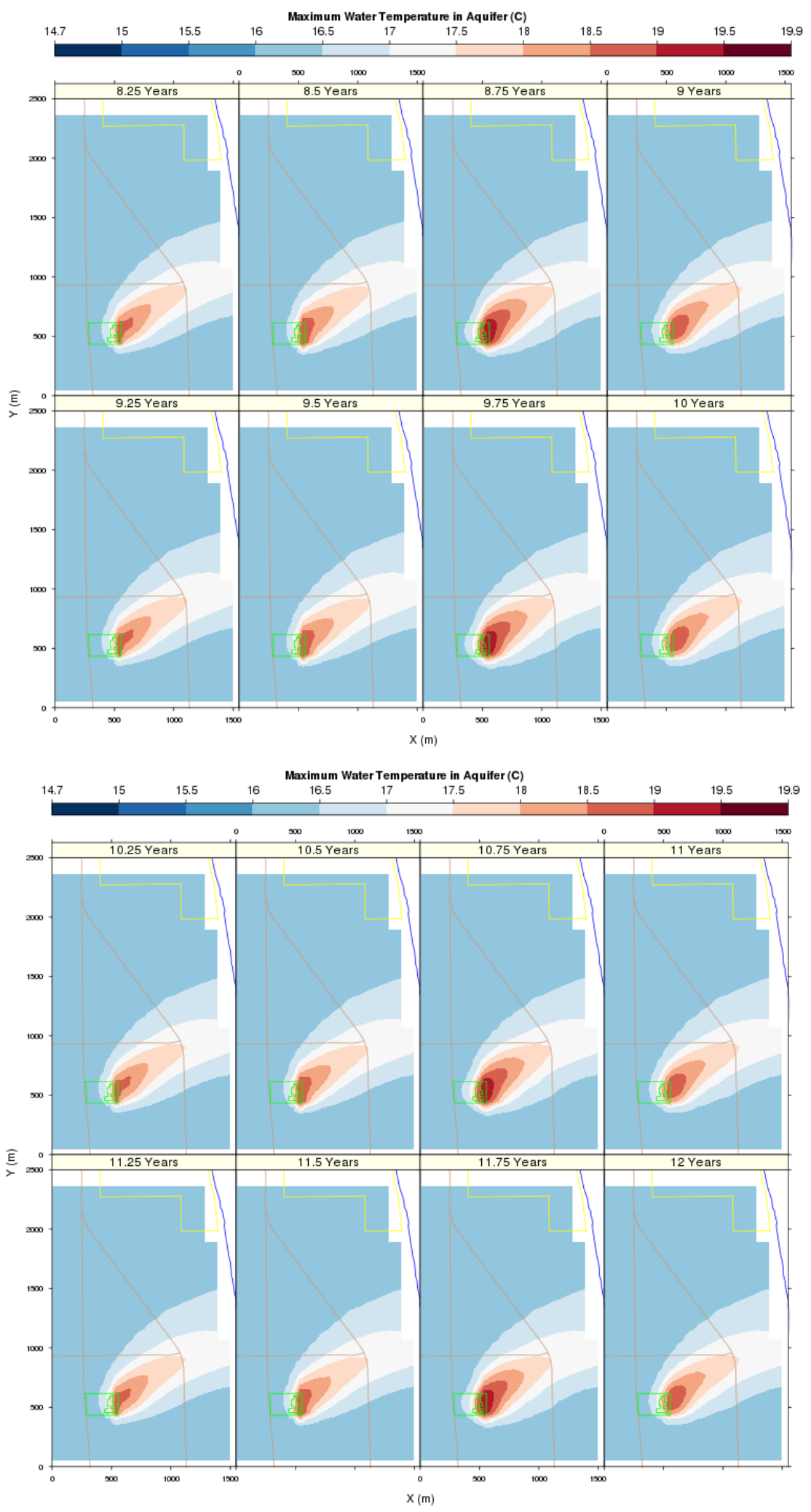

Figure H.1 (contd) 

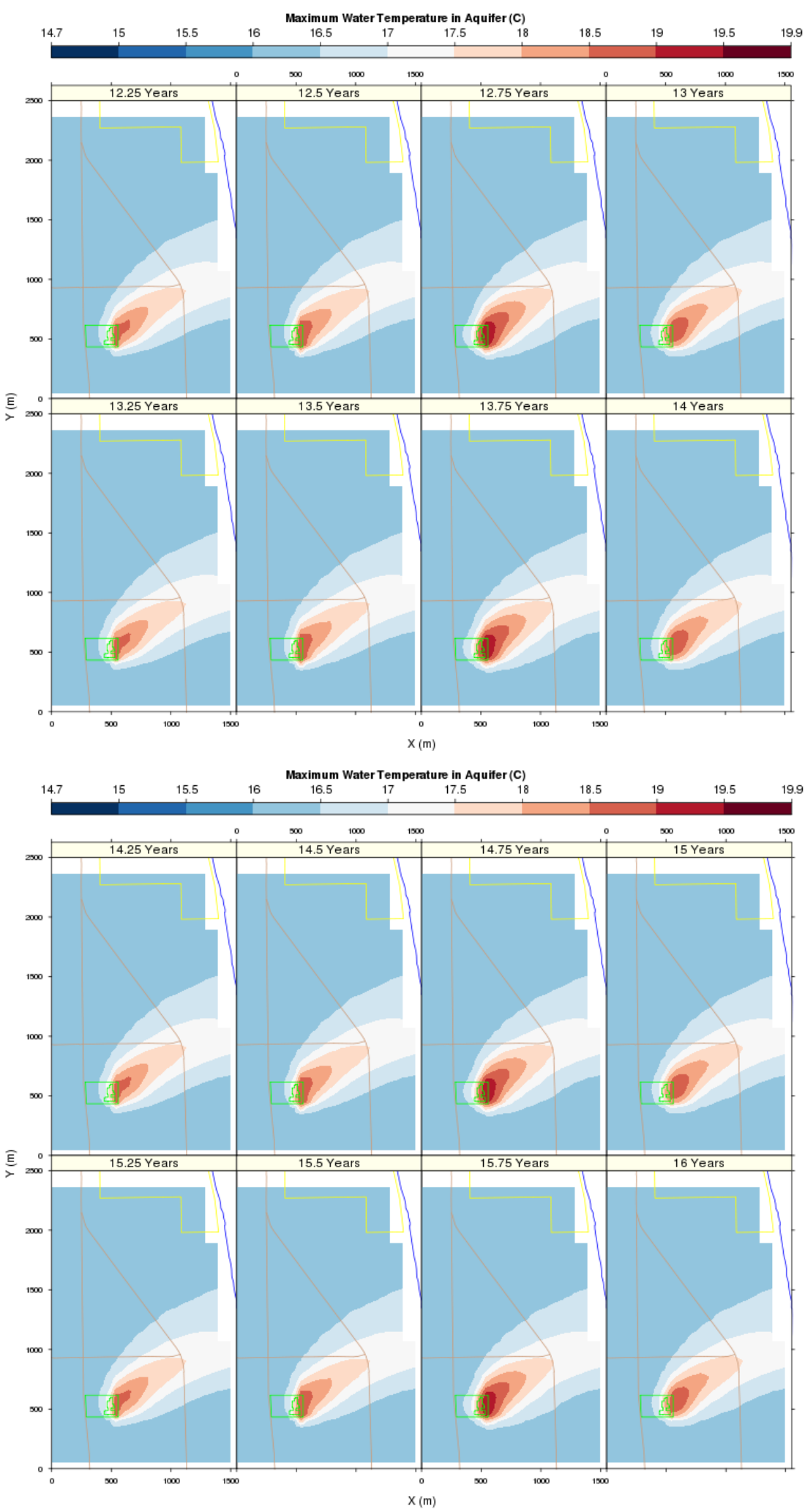

Figure H.1 (contd) 

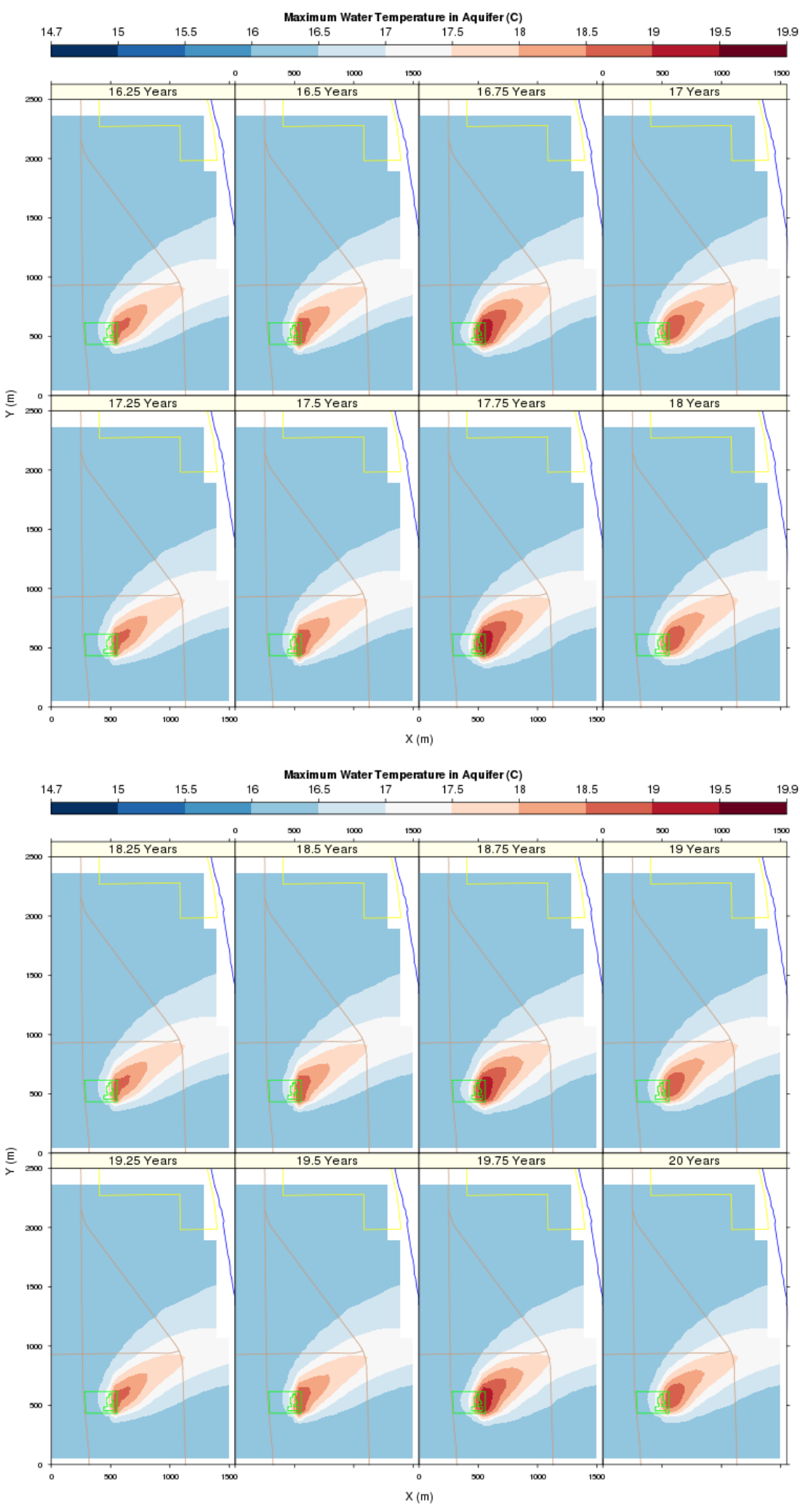

Figure H.1 (contd) 

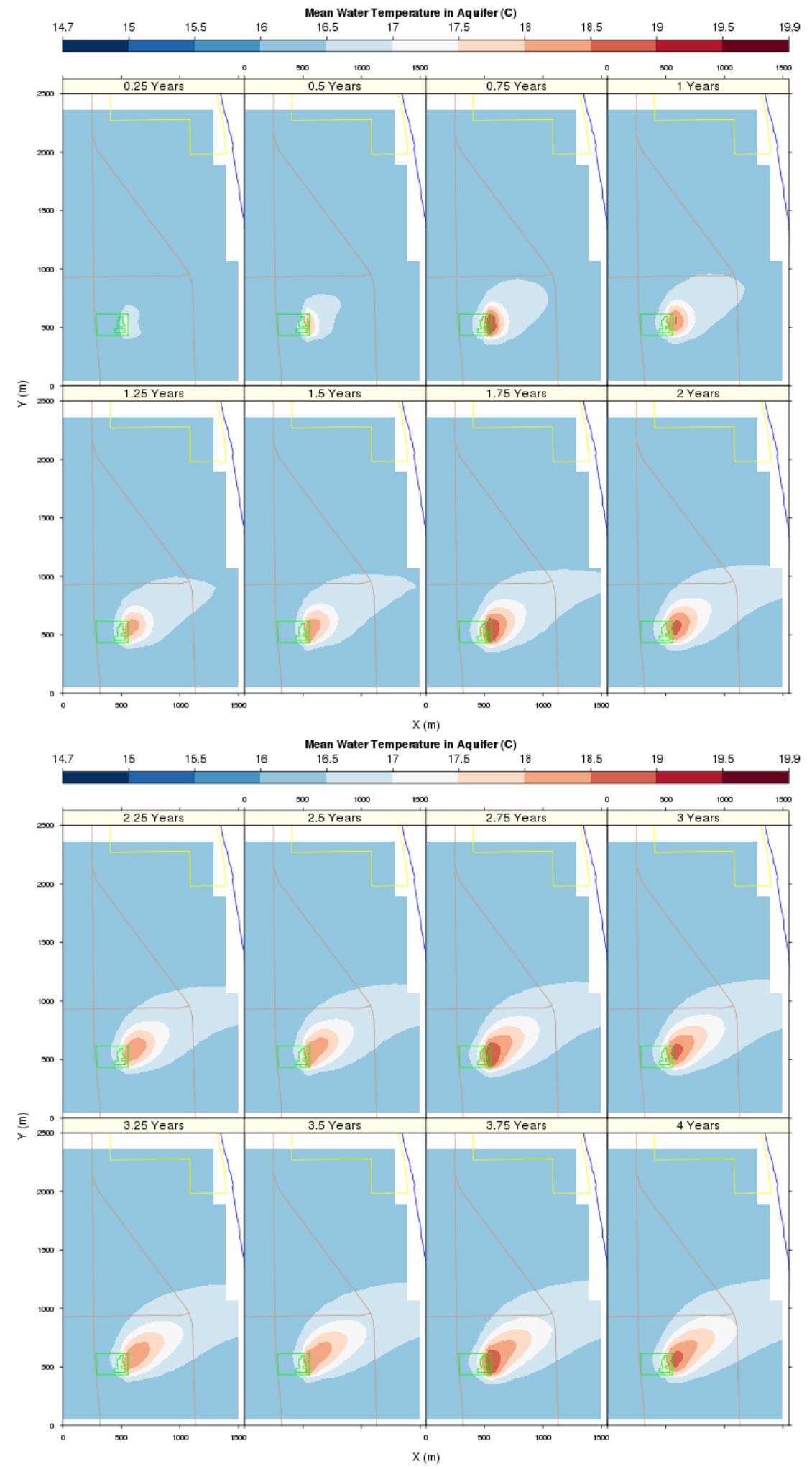

Figure H.2. Mean Temperature Distribution for Case 2b At Quarter Year Intervals 

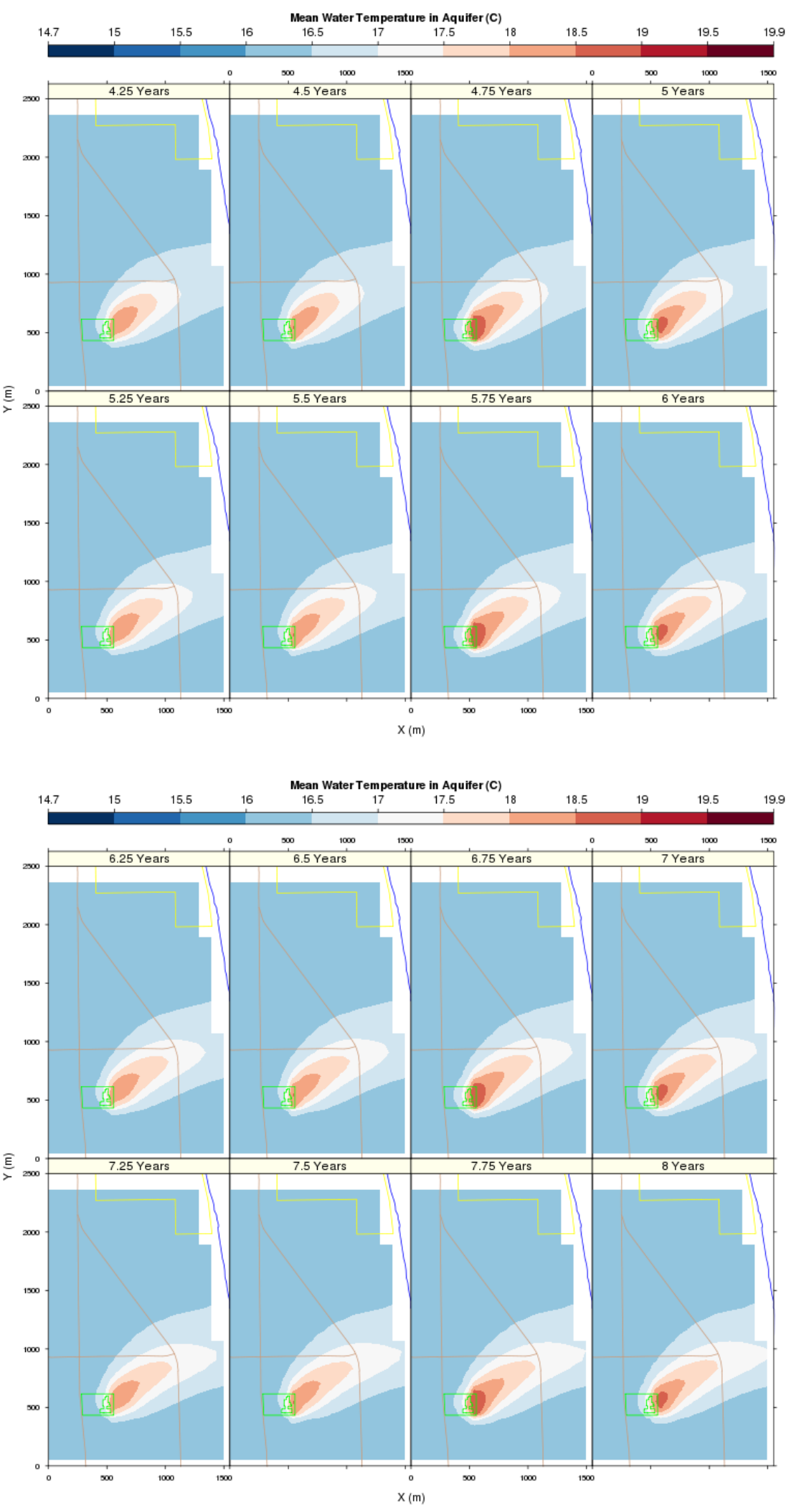

Figure H.2 (contd) 

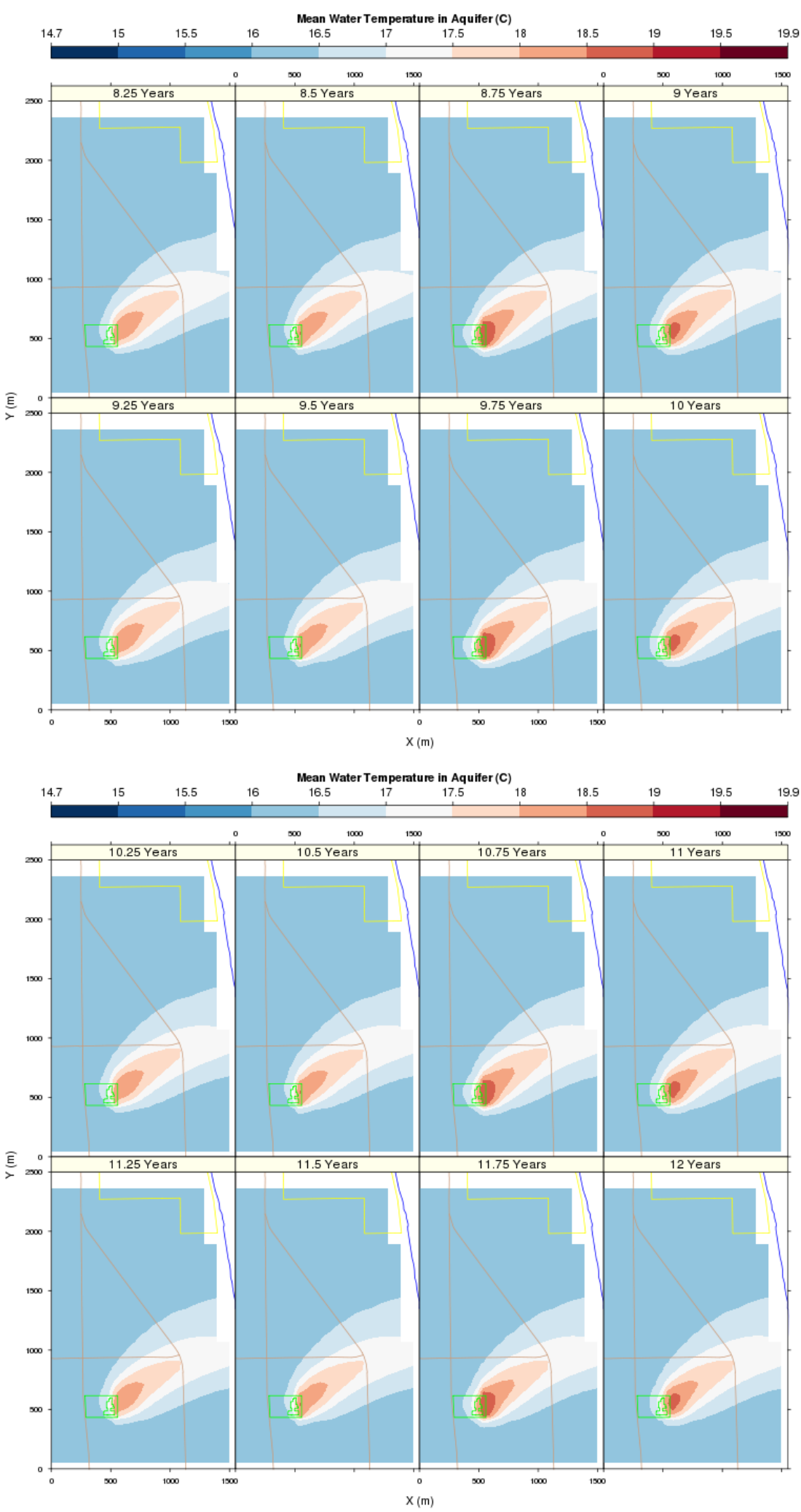

Figure H.2 (contd) 

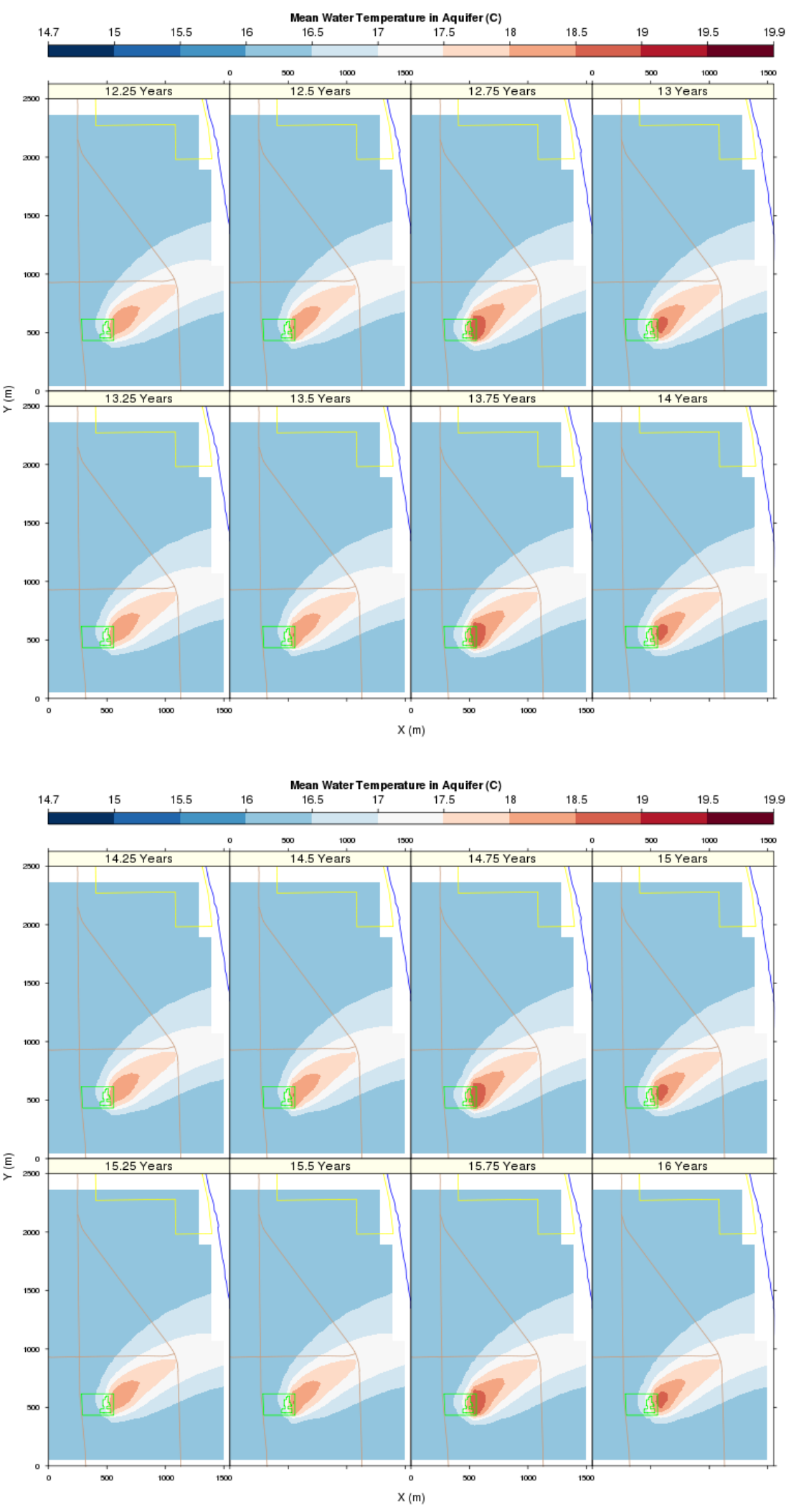

Figure H.2 (contd) 

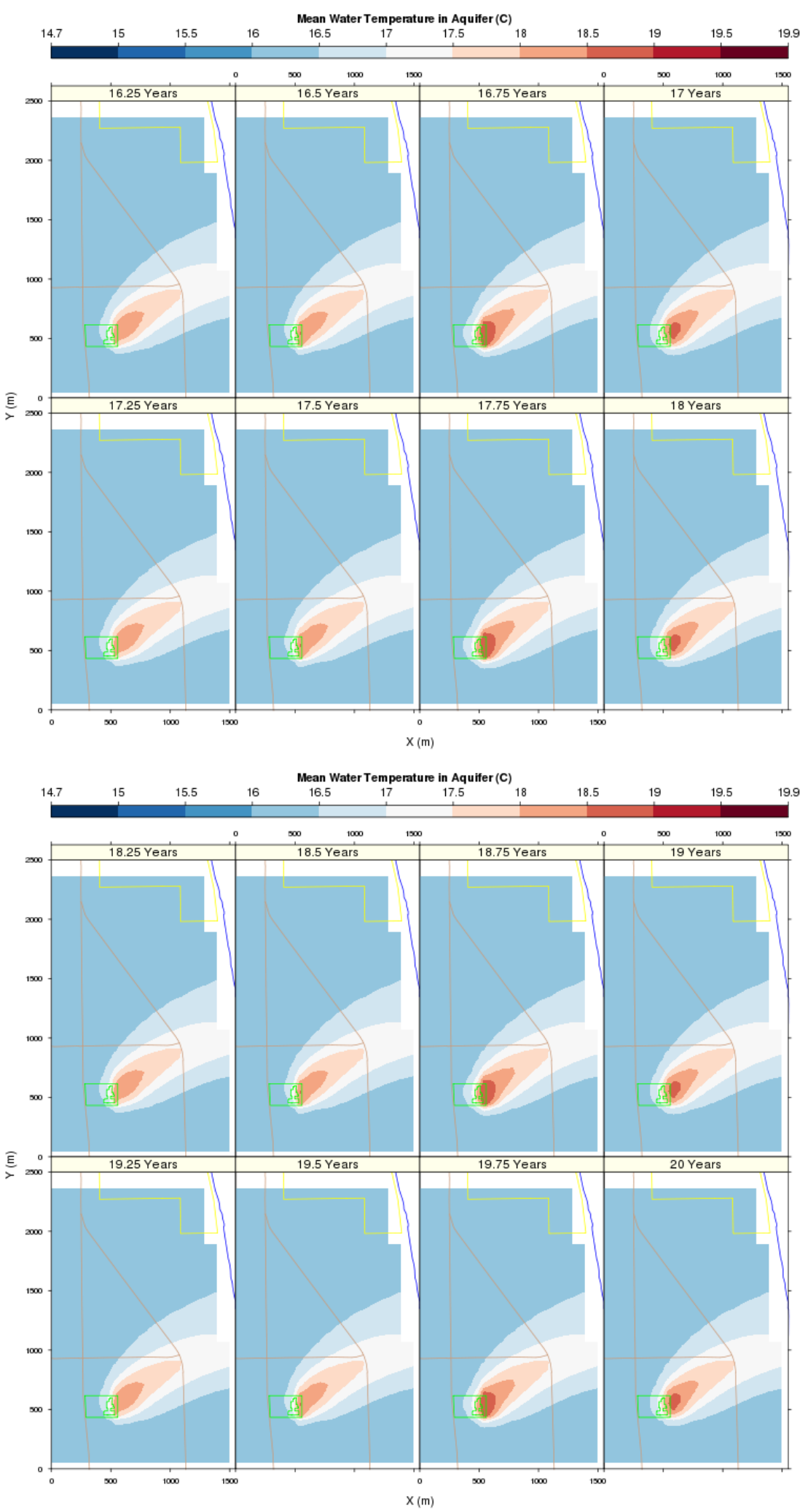

Figure H.2 (contd)

H.10 